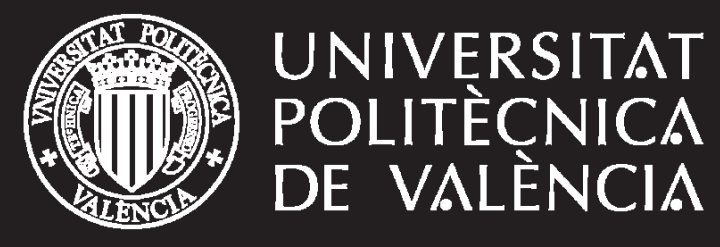

Departamento de Ciencia Animal

\title{
Caracterización de sistemas de producción de porcino y vacuno de engorde en Uruguay
}

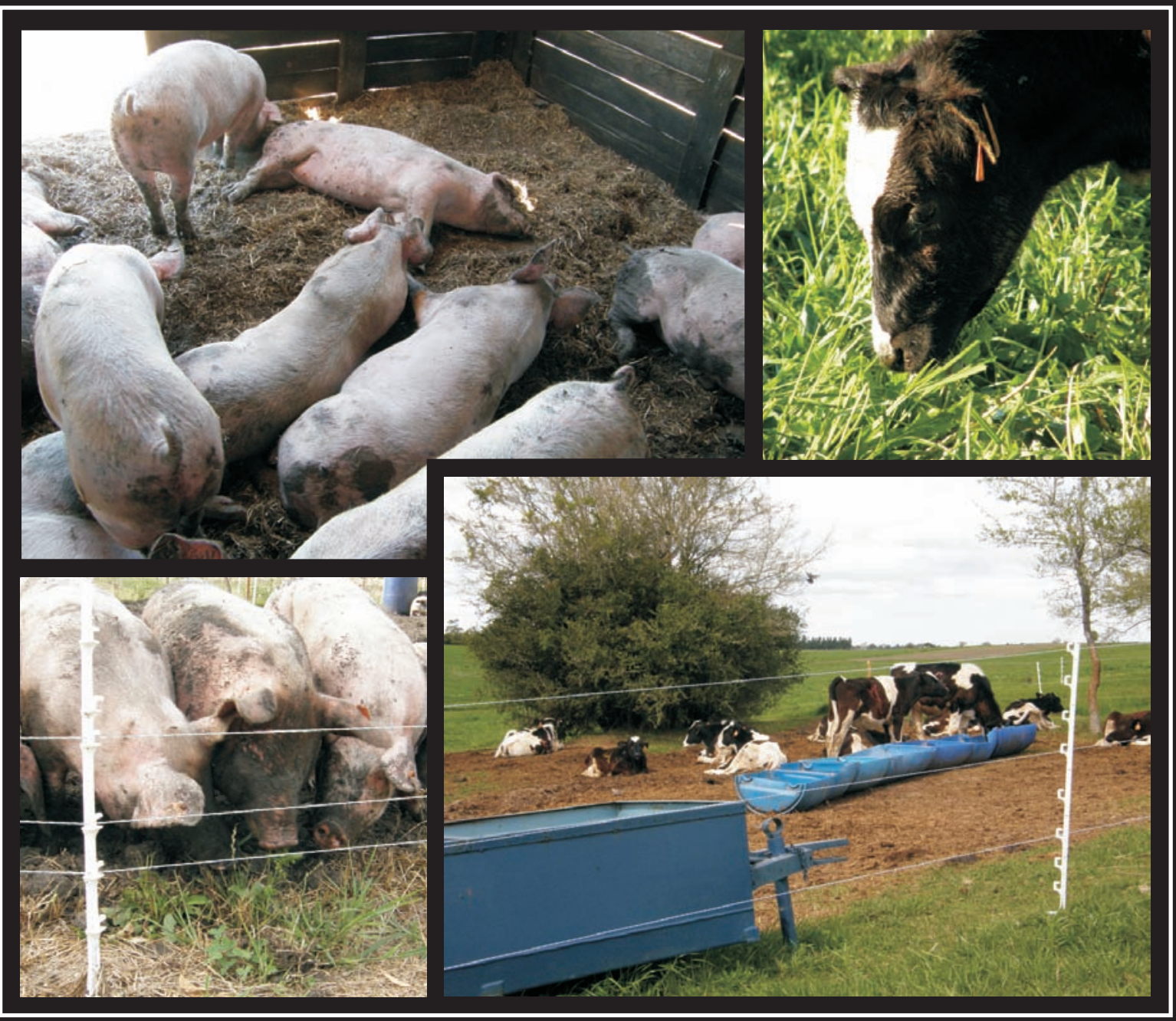

Oscar Blumetto Velazco

Directores:

Dr. Antonio Torres Salvador Dra. Aránzazu Villagrá García 



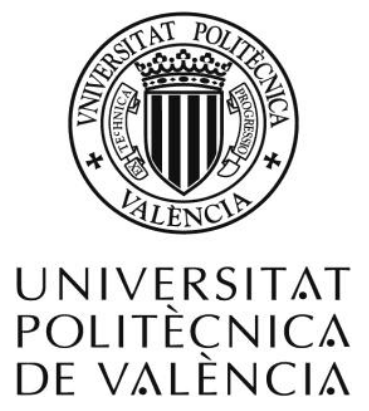

\section{CARACTERIZACIÓN DE SISTEMAS DE PRODUCCIÓN DE PORCINO Y VACUNO DE ENGORDE EN URUGUAY}

Directores:

Dr. Antonio G. Torres Salvador

Dra. Aránzazu Villagrá García Departamento de Ciencia Animal 

El aprendizaje es un simple apéndice de nosotros mismos; dondequiera que estemos, está también nuestro aprendizaje.

William Shakespeare

La alegría de ver y entender es el más perfecto don de la naturaleza.

Albert Einstein 



\section{$\underline{\text { Agradecimientos }}$}

Esta tesis ha sido posible gracias al financiamiento del Programa de Doctorados de los INIAs de Iberoamérica.

La investigación ha sido financiada por el Instituto Nacional de Investigación Agropecuaria de Uruguay con un importante apoyo académico y logístico del Departamento de Ciencia Animal de la UPV. 
En verdad quisiera agradecer a todas las personas que han hecho posible la realización de mi Doctorado, pero debería escribir un segundo tomo dedicado a ellos e igualmente podría olvidarme de algunos que merecen el agradecimiento. Por ello, voy a abreviar destacando a algunas personas que han tenido una participación significativa en alguna parte del proceso.

En primer lugar, un enorme agradecimiento a mis Directores, Antonio Torres y Arantxa Villagrá, quienes fueron mucho más que un soporte académico ya que desde el punto de vista personal también hicieron que a pesar de las distancias, siempre estuviera en mi casa.

A Salva y Fernando, por que han estado en tantas cosas que ya ni me acuerdo, seguro que en muchas más de las que hubiesen querido, pero bueno... Les tocó en suerte por decirlo de alguna manera!!

A Adriana, Andrea, Gustavo, Gabriel, Marcia, Fabio, Alfredo, Aldo, William, Denis, Gerardo,Carlitos, Pablo, Ma. Emilia y Mónica, compañeros de INIA, que desde sus distintas ocupaciones han hecho sus aportes para lograr llegar a buen puerto.

A Gonzalo, Tatiana y Marcela, jóvenes profesionales que hicieron sus pasantías en Las Brujas y les tocó compartir mucho del trabajo duro.

A Pau, María, Martita, Andrés, Yolanda, Mạ Carmen, Vero, Elena, Marta, Elisa y Mila, mis compañeros del Departamento de Ciencia Animal, una peña increible que siempre estuvieron dispuestos a ayudar.

A todos los técnicos e investigadores del CITA, en especial a Irene, Mar, Patricia y Antonio quienes compartieron tareas conmigo en granja, laboratorio o despacho. 
Un gran agradecimiento a quienes fueron durante éste tiempo Directores del CITA Manuel Lainez y Ernesto Gómez por facilitarme siempre la participación en una gran cantidad de trabajos de investigación.

A los investigadores del IRTA, en particular Toni Dalmau y Toni Velarde por su buena disposición a colaborar en la organización del trabajo experimental y el procesamiento de datos.

A los profesores Manuel Baselga y Jose Vicente, que siempre me facilitaron la vida en Valencia, desde mucho antes de que comenzara el doctorado.

Quiero agradecer mucho a mi familia, a todos, pero muy especialmente a $\mathrm{mi}$ esposa Adriana y mis hijos Yesi, Nadia y Nico, quienes tuvieron que hacerse valencianos por un tiempo, soportar alguna que otra larga ausencia y de vez en cuando sufrir algún pico de estrés cuando las cosas se me complicaban.

A mis padres Arabel y Ricardo, quienes han hecho en mi la más larga y desiteresada de sus inversiones.

Por último, no quiero olvidarme del Sr. Murphy, quien a travéz de su infalible Ley estuvo presente en cada minuto del trabajo de investigación y muy a su pesar la hemos acabado. 


\section{Resumen}

La producción ganadera es una de las actividades económicas más importantes de los países integrantes del Mercosur (Argentina, Brasil, Paraguay y Uruguay). Para Uruguay en particular, representa una de las fuentes de ingresos de divisas más importantes con exportaciones a múltiples mercados en todo el mundo. En los últimos años han crecido a nivel internacional las exigencias en materia de las condiciones de producción de los productos derivados de la ganadería, con especial énfasis en los temas medioambientales y de bienestar animal. En este sentido, el trabajo realizado en la presente tesis pretende realizar aportes en la caracterización de diferentes sistemas de producción desde el punto de vista productivo, de comportamiento y bienestar animal, así como de aspectos medioambientales. Para ello se realizaron trabajos en dos diferentes especies, bovinos y porcinos, y en diferentes sistemas de producción. Los dos primeros capítulos corresponden a tres sistemas de producción de bovinos con diferentes grados de intensificación: uno con animales en confinamiento permanente, un sistema exclusivamente pastoril y un sistema intermedio que combina confinamiento y pastoreo por seis horas. En ellos se caracterizan aspectos productivos, se establece los patrones de uso del tiempo, las tendencias diarias en cada comportamiento y la asociación de los mismos con las condiciones ambientales. Paralelamente se cuantifican las interacciones sociales en los diferentes sistemas, y varios indicadores fisiológicos y sus posibles implicaciones en el bienestar animal. En los restantes dos capítulos se analizan dos sistemas opuestos de producción de cerdos: uno tradicional con cerdos en confinamiento y un sistema alternativo con cerdos al aire libre con acceso a pasturas. Estos sistemas se caracterizan en los aspectos medioambientales, productivos y características de la carne resultante. Además se realiza una caracterización de los aspectos de comportamiento general y comportamiento social agonístico, así 
como de otros parámetros fisiológicos, todos ellos como indicadores del bienestar de los animales.

Esta tesis ha permitido caracterizar los sistemas propuestos, encontrando que los sistemas evaluados no presentan características que puedan comprometer seriamente el bienestar de los animales. Sin embargo, se obtuvieron indicios de que los diferentes sistemas afectan el comportamiento de los animales y podrían provocar diferentes niveles de estrés. Por su parte, los sistemas con inclusión de pastoreo podrían tener una menor eficiencia biológica de utilización de los nutrientes por parte de los animales tanto en vacunos como en cerdos. Desde el punto de vista medioambiental, se han podido visualizar las pautas de distribución de nutrientes en el terreno, en el caso de cerdos al aire libre. 


\section{Abstract}

Livestock production is one of the most important economic activities of the Mercosur countries (Argentina, Brazil, Paraguay and Uruguay). In Uruguay it represents one of the main sources of incomes from exports which are destined to multiple markets worldwide. In recent years, the international demand on the conditions of production of livestock products, with special emphasis on environmental issues and animal welfare has increased. In this way, the aim of this $\mathrm{PhD}$ thesis is to characterize different production systems from a productive, behavioral, welfare, and environmental point of view. This work was carried out in two different species, cattle and pigs, and in different production systems. The first two chapters deal with three steers production systems with different degrees of intensification: confined system, pastoral conditions and an intermediate option that combines confinement and grazing for six hours. They are characterized in productive aspects, as well as the general use of time and daily trends in each behavior and its association to the environmental conditions. At the same time, social interactions were registered in the three production systems and several physiological indicators determined, in order to analyze their influence on animal welfare. In the remaining two chapters two contrasting systems of pig production are assessed: a traditional indoor fattening system and an alternative outdoor system with access to pastures. Both systems are characterized in productive and environmental aspects and meat quality characteristics. General behavior and agonistic social behavior are also characterized, as well as other physiological parameters.

This thesis has characterized the proposed systems and it has been found that any of them seriously compromise the welfare of the animals. Nevertheless, we found that the different production systems affected the behavior of the animals and could cause different levels of stress. On the other hand, systems including 
grazing may have a reduced biological efficiency of nutrient utilization, both in cattle and pigs. From an environmental point of view, an approximation to the distribution patterns of nutrients in the soil has been found. 


\section{Resum}

La producció ramadera és una de les activitats econòmiques més importants dels països integrants del Mercosur (Argentina, Brasil, Paraguai i Uruguai). A l'Uruguai en particular, representa una de les fonts d'ingressos de divises més importants, amb exportacions a múltiples mercats de tot el món. Als últims anys, han crescut a nivell internacional les exigències que envolten les condicions de producció dels productes derivats de la ramaderia, amb especial èmfasi en aspectes de medi ambient y de benestar animal. En aquest sentit, el treball realitzat en la present tesi pretén realitzar una aportació en la caracterització de diferents sistemes de producció, des del punt de vista productiu, de comportament i de benestar animal, així com d'aspectes mediambientals. Per tal d'això, es realitzaren treballs en diferents espècies (bovins i porcins) i en diferents sistemes de producció. Els dos primers capítols corresponen a tres sistemes de producció de bovins, amb diferents graus d'intensificació: un d'ells amb animals en confinament permanent; un altre sistema de pasturatge exclusivament i l'últim, un sistema que combina confinament amb pasturatge durant sis hores. En ells es caracteritzen aspectes productius, s'estableix l'ús general del temps, les tendències diàries en cada comportament i l'associació dels mateixos amb les condicions ambientals. Paral-lelament, es quantifiquen les interaccions socials en els diferents sistemes, $\mathrm{i}$ diferents indicatius fisiològics i les possibles implicacions en el benestar animal. En els restants dos capítols, s'analitzen dos sistemes ben diferents de producció de porcs: el primer d'ells és un sistema de producció tradicional amb porcs confinats, mentre que el segon és un sistema alternatiu de porcs a l'aire lliure amb accés a pastura. Aquests sistemes es caracteritzen en aspectes mediambientals, productius i de característiques de la carn resultant. A més a més, es realitza una caracterització dels aspectes de comportament general i de comportament social 
agonístic, així com d'altres paràmetres fisiològics, tots ells com a indicadors del benestar dels animals.

Aquesta tesi ha permès caracteritzar els sistemes proposats, trobant que els sistemes avaluats no presenten característiques que puguen comprometre sèriament el benestar dels animals. En canvi, s'han obtingut indicis de que els diferents sistemes afecten al comportament dels animals i podrien provocar diferents nivells d'estrès. Per altra banda, els sistemes amb inclusió de pastura podrien tindre una menor eficiència biològica d'utilització dels nutrients per part dels animals, tant en boví com en porcí. Des d'un punt de vista mediambiental, s'han pogut visualitzar les pautes de distribució de nutrients del terreny, en el cas de porcs a l'aire lliure. 


\section{Tabla de Contenidos}

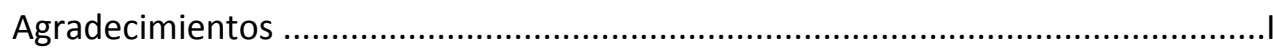

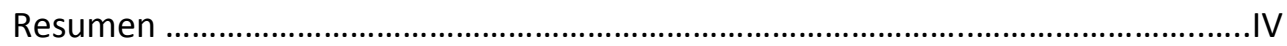

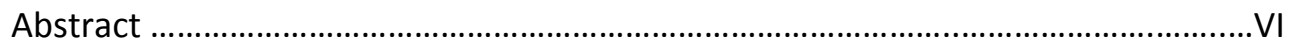

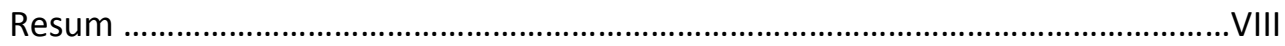

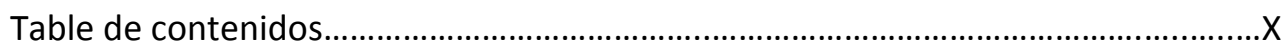

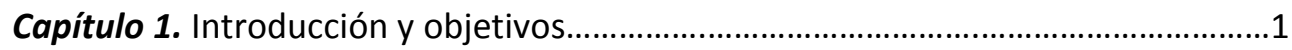

Capítulo 2. Behavioural characterization of three Holstein steers production systems

Capítulo 3. Productive, physiological and social behaviour characterization, of three contrasting production systems of Holstein steers

Capítulo 4. Caracterización productiva y ambiental de un sistema de engorde de cerdos en extensivo: análisis del ciclo de los nutrientes.

Capítulo 5. Ethologic, physiologic and meat characterization of extensive or intensive pigs production systems in Uruguay .159

Capítulo 6 Discusión general y Conclusiones. .209 


Capítulo 1

Introducción y objetivos 



\section{Introducción}

\subsection{La importancia de la ganadería en el Mercosur, el caso de Uruguay}

La región sur de Sudamérica tiene una larga tradición ganadera y este sector ha sido vital en la economía de los países integrantes del Mercosur, compuesto por Argentina, Brasil, Paraguay y Uruguay. De acuerdo con las conclusiones del $18^{\circ}$ Congreso Mundial de la Carne, realizado en 2010 en Buenos Aires, no hay dudas de que en la próxima década se reafirmará el predominio del Mercosur en la producción de carne en el nivel global (Colombres, 2010). Según la FAO, en estos países los productos derivados de la producción animal están entre las principales producciones. A modo de ejemplo en la Tabla 1 se muestra un ranking de los principales 10 países productores de tres de los principales productos de origen animal en la región y la ubicación de Uruguay en dicho ranking.

Tabla 1- Ranking de los principales países productores de carne bovina, leche bovina y lana de oveja a nivel mundial en 2010 y ubicación de Uruguay en dicho ranking (FAOSTAT, 2011)

\begin{tabular}{cccc}
\hline \hline Posición en el ranking & Carne bovina & Leche bovina & Lana de oveja \\
\hline 1 & Estados Unidos & Estados Unidos & Australia \\
2 & Brasil & India & China \\
3 & China & China & Nueva Zelandia \\
4 & Argentina & Brasil & Irán \\
5 & Australia & Alemania & Reino Unido \\
6 & México & Francia & Argentina \\
7 & Federación Rusa & Federación Rusa & Marruecos \\
8 & Francia & Nueva Zelandia & Sudán \\
9 & Alemania & Reino Unido & Federación Rusa \\
10 & Canadá & Italia & Siria \\
Uruguay & $\mathbf{2 0}$ & $\mathbf{4 6}$ & $\mathbf{1 4}$ \\
\hline
\end{tabular}


Por otro lado en la década del 2000, los países del Mercosur han tenido el mercado externo como su primer destino comercial. Por ejemplo, Brasil, Paraguay y Uruguay son los principales proveedores de Rusia que es el cuarto importador mundial de carne con un monto total de 2.174 millones de dólares (UN Comtrade, 2011). Brasil se destaca sobre los demás países del bloque, experimentando un crecimiento muy significativo ligado al aumento de la demanda de China. De acuerdo a los datos del USDA, los países integrantes del Mercosur participan con el $40 \%$ de las exportaciones mundiales (Zarza, 2010). En ese informe de la Secretaría de Agricultura Ganadería y Pesca de Argentina, por razones sanitarias, Uruguay es el único país del bloque con acceso a los mercados estadounidense y canadiense.

La UE-27 también tiene como principal proveedor a los países del Mercosur. Esta situación no es fortuita, sino que se debe nuevamente a las diferentes restricciones sanitarias que permiten que Brasil, Argentina y Uruguay realicen envíos de carne fresca y congelada además de procesada, lo cual amplía su participación de mercado y los posiciona en lugares de privilegio respecto de los demás países (Zarza, 2010).

En este sentido la ganadería uruguaya goza de un punto de partida privilegiado dado su estatus sanitario en todas las especies domésticas, pero en particular por estar libre de Fiebre Aftosa y Encefalopatía Espongiforme Bovina. Esta situación ha mejorado su inserción en el mercado internacional de la carne, duplicando los volúmenes de carne bovina exportados entre 1990 y 2010, pero también duplicando el precio promedio percibido, lo que representa un ingreso de divisas por este concepto de 873 millones de dólares (OPYPA, 2010). Las exportaciones de los productos de origen animal en 2010 representaron el 32 \% del total de exportaciones de bienes del país $(B C U, 2011)$ y en algunos de dichos productos 
Uruguay se ubica entre los principales exportadores mundiales, como puede observarse en la tabla 2.

Tabla 2- Ranking de los principales países exportadores de carne bovina, leche bovina y lana de oveja a nivel mundial en 2010 y ubicación de Uruguay en dicho ranking (UN Comtrade, 2011)

\begin{tabular}{cccc}
\hline $\begin{array}{c}\text { Posición en el } \\
\text { ranking }\end{array}$ & Carne bovina & Derivados lácteos & Lana de oveja \\
\hline 1 & Australia & Alemania & Australia \\
2 & Brasil & Nueva Zelandia & China \\
3 & Estados Unidos & Francia & Nueva Zelandia \\
4 & Holanda & Holanda & Alemania \\
5 & Alemania & Belgica & Sudáfrica \\
6 & Irlanda & Estados unidos & Argentina \\
7 & India & Australia & Uruguay \\
8 & Nueva Zelandia & Dinamarca & Italia \\
9 & Francia & Polonia & República Checa \\
10 & Canadá & Reino Unido & Reino Unido \\
Uruguay & $\mathbf{1 1}$ & $\mathbf{2 5}$ & $\mathbf{7}$ \\
\hline
\end{tabular}

No obstante, el mercado interno sigue siendo muy importante a pesar de la baja población del país (3.2 millones de habitantes), y los datos del Instituto nacional de Carnes (INAC) muestran consumos elevados, que alcanzaron en 2010 los valores per cápita de $61 \mathrm{~kg}$ de carne bovina, $20 \mathrm{~kg}$ de carne aviar, $9 \mathrm{~kg}$ de carne porcina y $4 \mathrm{~kg}$ de carne ovina (Presidencia de la República Oriental del Uruguay, 2010). La disminución del consumo de carne roja en Argentina (56.1 kg por 
persona y año en 2009) posicionó a Uruguay como el primer consumidor a nivel mundial (Marti, 2010).

En Producto Interno Bruto (PIB) agropecuario de Uruguay, en dólares corrientes, alcanzó el récord de 2.930 millones de dólares, representando el $9.1 \%$ del total de la economía en 2008 (OPYPA, 2009). Considerando el sector agrícola-ganadero y las industrias asociadas, el peso en la economía nacional uruguaya es muy alto, representando un $12 \%$ del PIB total (INE, 2011). La importancia social de la ganadería es también muy alta, ya que involucra 126.800 personas residentes en los predios (DIEA, 2003). Además, de acuerdo con los datos del censo agropecuario del 2000, el número de trabajadores permanentes por cada mil hectáreas es de 5,84 para la ganadería bovina, 9,18 para la ganadería ovina, 22 para la producción lechera, 262 para la producción de aves y 128 para producción de cerdos, a todo lo cual se agregan 20 trabajadores cada mil hectáreas en la prestación de servicios de maquinaria (Carrere, 2002).

En este contexto de un mercado internacional muy importante para el ingreso de divisas al país, un relevante mercado interno por los volúmenes consumidos y la creciente influencia de las políticas comerciales aplicadas en la región y el mundo, el sector enfrenta diversos desafíos para mantenerse económicamente viable ante las crecientes exigencias de la sociedad.

La seguridad alimentaria, el bienestar animal y la protección del medio ambiente son exigencias de la sociedad para la ganadería a nivel mundial y en este contexto Uruguay ha tomado y deberá seguir incrementando las medidas para atender dichas exigencias. En el siguiente apartado se tratan en mayor detalle estos aspectos. 


\subsection{Desafíos de la ganadería uruguaya}

Así pues el país debe estar en constante revisión del desempeño del sector y la evolución de las demandas de los mercados internacionales. En los siguientes puntos se analizan los desafíos que enfrentará la producción ganadera en el futuro próximo en materia de su estructura socioeconómica, aspectos vinculados al bienestar de los animales y los aspectos relacionados al impacto ambiental de la actividad.

\subsubsection{Aspectos estructurales y socioeconómicos}

El país ha tomado una serie de medidas o iniciativas para el fortalecimiento de las cadenas comerciales tanto en aspectos de la producción como de la comercialización, los que podemos considerar como de tipo estructural en el sector. En este sentido las regulaciones del sector han sido incrementadas muy fuertemente en la última década. Un ejemplo lo constituye la trazabilidad electrónica total obligatoria del ganado por la Ley 17.997 (Poder Legislativo, 2009), que le permite asegurar todo los pasos de la cadena desde el productor hasta el minorista, distribuidor final y el consumidor. Esto es un aporte sustantivo en la mejora de la seguridad alimentaria y de la confianza de los mercados, pero además facilita la implementación de programas de certificación de productos y de procesos. Con este fin el INAC ha publicado el Manual de Control de Calidad que permitirá organizar el control Oficial de Calidad Comercial, función que el Instituto tiene asignado por la Ley 15.605 (INAC, 2009). Complementariamente el Instituto ha implementado el Programa Nacional Carne Natural Certificada del Uruguay (PNCNCU). En agosto de 2004, el Programa fue oficialmente reconocido por el Departamento de Agricultura de los Estados Unidos (USDA) en cuanto a calidad de producto, manejo animal y verificación de origen. De esta forma el 
PCNCU se transforma en el primer programa internacional en estar certificado bajo el Programa de Procesos Verificados de USDA y así poder utilizar su etiqueta junto a otras 16 compañías de Estados Unidos. Este programa también ha sido homologado por la Norma Global GAP (INAC, 2011).

La estrategia ha sido poner en valor las características medioambientales de los sistemas de producción, el bienestar animal y la calidad del producto basando en ello la estrategia comercial del país, como lo muestran los logotipos diseñados para el etiquetado y promociones (véase Figura 1).

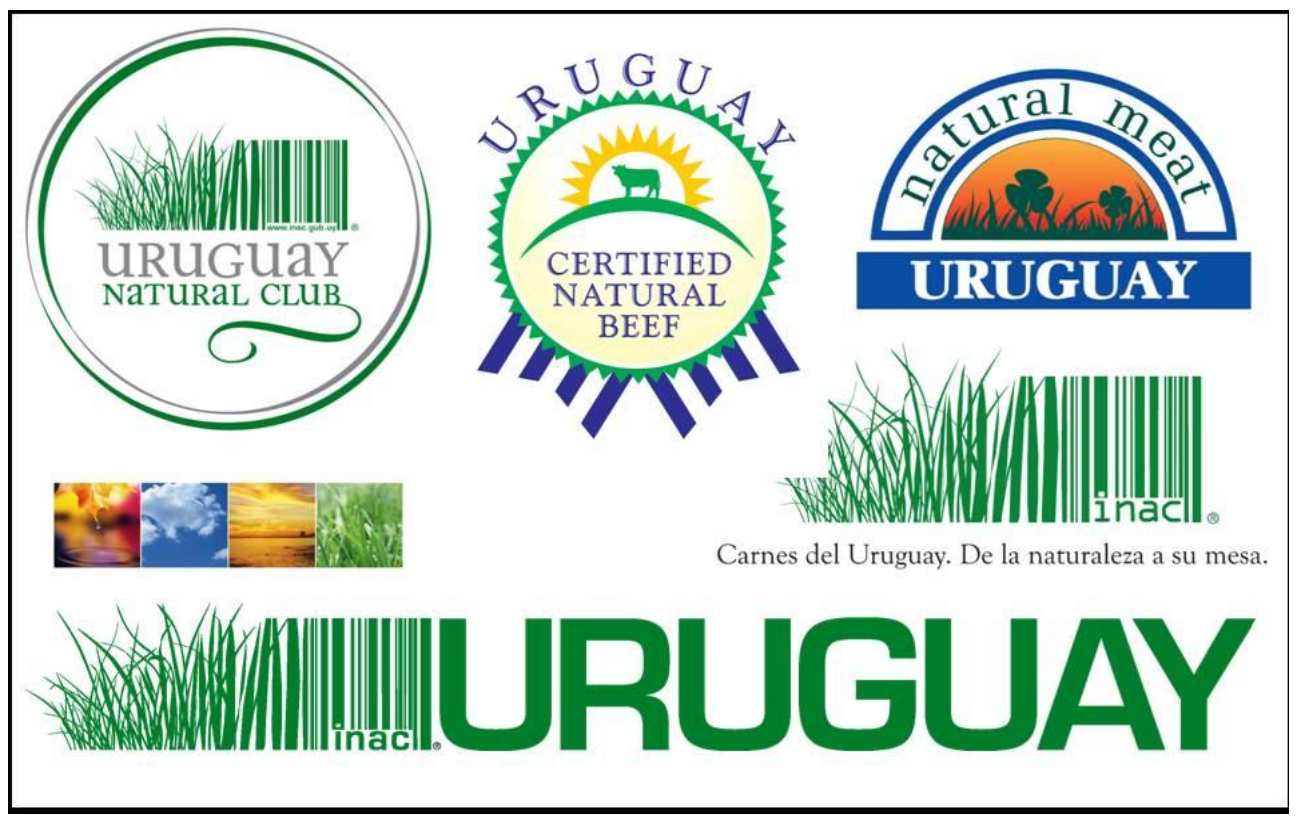

Figura 1 - Ejemplos de logotipos de promoción y etiquetado de carnes uruguayas

(Fuente: INAC)

Otros aspectos estructurales con repercusiones socioeconómicas no responden a medidas directas, pero si a una conjunción de elementos macroeconómicos con implicancias sociales, como por ejemplo la competencia de la superficie agraria 
entre cultivos y ganadería, en especial la soja, que ha desplazado la ganadería hacia zonas con suelos de menor productividad, más restricciones de uso y riesgo de degradación (Sawchik, 2010).

Por otra parte, legislación reciente tiende a desincentivar la tenencia de grandes superficies de tierras por sociedades anónimas innominadas como la Ley 18.092 (Poder Legislativo, 2007) y el Poder Ejecutivo aprueba un Proyecto de Ley que gravará con impuestos a Inmuebles Rurales que superan las 2.000 hectáreas con un índice Coneat 100 (Presidencia de la República, 2011). Este índice expresa la productividad potencial de la tierra en $\mathrm{Kg}$ de carne equivalente por hectárea de campo natural y se encuentra disponible para todo el país. Estas dos normativas pueden resultar en un desestimulo a la producción ganadera en grandes superficies y afectar a la estructura social del sector.

Los aspectos relacionados con la temática medioambiental y de bienestar animal, han tenido una gran atención por parte de las políticas públicas y acciones privadas, pero seguirán demandando atención en el futuro próximo, por lo cual dichos aspectos serán tratados en mayor detalle.

\subsubsection{Aspectos relacionados con el bienestar animal}

El bienestar animal comenzó a tener una importancia muy marcada en la agenda oficial en Uruguay en la última década. En 2004, el Ministerio de Ganadería Agricultura y Pesca (MGAP) crea un grupo técnico sobre bienestar animal, considerando recomendaciones de la Organización Internacional de Epizotias (OIE) emergidas de la primera Conferencia Global sobre Bienestar Animal realizada en París en 2004 y que diferentes misiones internacionales de auditoría ponían especial énfasis en la temática. Ello determinó la necesidad de comenzar a implementar acciones concretas. El objetivo principal era proponer 
recomendaciones de buenas prácticas objetivas, adecuadas a la realidad nacional y en consonancia con la normativa internacional en la materia (Muzio, 2007). A partir de 2003, el INAC publica una serie de manuales para manejo del ganado previo al sacrificio, alternativas de manejo y buenas prácticas operacionales. En 2005 se publica un manual para las buenas prácticas en el manejo del transporte y el sacrificio de bovinos y ovinos, realizado conjuntamente por el MGAP, INAC, el Instituto Nacional de Investigación Agropecuaria (INIA) y la Facultad de Veterinaria de la Universidad de la República (Castro, 2007).

También el Sistema Nacional de Investigación ha tomado medidas para considerar el bienestar animal. Desde el año 2000 funciona la Comisión Honoraria de Experimentación Animal y en noviembre de 2009 se aprobó en el Parlamento, la Ley 18.611, denominada "Utilización de animales de experimentación, docencia e investigación científica". En la ley se disponen normas en cuanto al trato de los animales experimentales, evitando el sufrimiento y estableciendo diferentes exigencias para el uso y manejo de animales en el país. Esta ley crea la Comisión Nacional de Experimentación Animal (CNEA) la cual tiene representantes de las instituciones de investigación y la sociedad civil. Además, esta leyestipula una serie de penalidades por el incumplimiento de la misma.

En 2009 se aprueba la Ley 18.471 sobre normas relacionadas al Bienestar Animal (Poder Legislativo ROU, 2009) con lo cual el tema hoy se encuentra presente en normativas nacionales de alto rango jurídico.

Por las características de los sistemas de producción dominantes en Uruguay, con predominancia de los sistemas extensivos y el fuerte interés oficial y productivo en el tema, podría considerarse el bienestar animal como uno de los aspectos menos restrictivos para el sector y, en consecuencia, el país cuenta con un buen posicionamiento en el mercado nacional e internacional en esta materia. 
Sin embargo, dado el nivel de exigencia a nivel local y el interés por cumplir con las crecientes demandas de los países a los cuales se destina la producción, existen oportunidades de mejora en varios eslabones de la cadena agroindustrial.

En tal sentido existen al menos cuatro grandes áreas de análisis: los sistemas pastoriles, los nuevos sistemas intensivos, el transporte y las plantas de sacrificio. Los dos primeros aspectos afectan directamente a la base productiva, y se analizan en mayor detalle dado que forma parte de los objetivos de estudio de esta tesis.

Los sistemas pastoriles presentan pocas restricciones al desarrollo del comportamiento natural de los animales, pero algunos aspectos de manejo podrían afectar el bienestar de los mismos. En este sentido, en sistemas extensivos de la región, los aspectos detectados como posibles restricciones para el bienestar animal son el diseño de las instalaciones (corrales, embarcaderos, etc.), algunas prácticas de manejo como el traslado con el uso de perros y las dificultades para realizar tratamientos sanitarios a los animales (Grandin, 2008). Estos aspectos sin embargo, están siendo reducidos por un constante esfuerzo a nivel de divulgación de buenas prácticas a nivel nacional (Barros y Castro, 2009). No obstante, existen aspectos que afectan al bienestar animal que son más difíciles de controlar, como la posibilidad de desastres naturales o problemas nutricionales e incluso hambre por falta de oferta de alimento en situaciones de sequía extrema (Petherick, 2005). La exposición total a las condiciones climáticas, ha sido muchas veces mencionada como posible causa de un deterioro en las condiciones de bienestar, en especial el calor y la falta de sombra (Rovira y Velazco, 2011; Tucker et al., 2008; Schütz et al., 2010). Sin embargo Graunke et al. (2011) demostraron que los animales, aún sometidos a condiciones 
extremadamente frías y ventosas, aprenden a buscar sitios con microclimas que les permiten protegerse.

La intensificación en cambio, en especial los sistemas de producción en confinamiento, tiende a determinar nuevas restricciones que deben resolverse para reducir la problemática del bienestar de los animales. En este sentido, la disponibilidad de espacio es uno de los aspectos más importantes en la determinación de los aspectos del comportamiento de los animales y resulta crítico para su salud y bienestar (Petherick y Phillips, 2009). Otras cuestiones planteadas como problemas productivos, de salud y de bienestar en sistemas confinados, son la disponibilidad de comederos (Gottardo et al., 2004), el estrés térmico (Brown-Brandl et al., 2005), el ambiente pobre en estímulos (Bolhuis et al., 2005), el manejo de los animales y de las instalaciones (Barnett, 2007) y el aumento de las interacciones sociales negativas entre animales (Temple et al., 2011). Dada la baja importancia relativa de los sistemas intensivos, la incidencia de la mayoría de estos aspectos de manejo no han sido aún determinados y por tanto no se han reglamentado en Uruguay.

\subsubsection{Aspectos relacionados con la protección del medio ambiente}

Entre los aspectos medioambientales relacionados con la producción ganadera hay factores que afectan a la propia granja o a su entorno cercano, como las emisiones de amoníaco (Krupa, 2003; Roney et al., 2004) o material particulado en el caso de la producción intensiva (Cambra-López et al., 2010) y la acumulación de N, P y otros minerales proveniente de las deyecciones (Burton y Turner, 2003). Otros pueden tener trascendencia en una escala regional, donde los efectos podrían ser medidos a nivel de cuenca hidrográfica, ecosistema o paisaje. En esta escala, el manejo de los efluentes es la cuestión más importante ya sea que éstos 
sean distribuidos naturalmente como en el caso de los sistemas pastoriles, como en su manejo y posterior aplicación en los sistemas confinados (Burton y Turner, 2003). En este caso los efectos no son solo sobre el suelo, sino que también puede haber afectación de aguas superficiales y subterráneas. A esta escala también comienzan a ser evidentes problemas de pérdida de biodiversidad (Jaurena et al, 2011; Steinfeld et al., 2006).

Por último existen efectos a escala global, relacionados con las emisiones de gases de efecto invernadero, entre los cuales los más importantes derivados de la actividad ganadera son: el dióxido de carbono $\left(\mathrm{CO}_{2}\right)$, el metano $\left(\mathrm{CH}_{4}\right)$ y el óxido nitroso $\left(\mathrm{N}_{2} \mathrm{O}\right)$ (Safley et al., 1992). Según el informe de la FAO "La larga sombra del ganado", el sector ganadero es responsable del 18 por ciento de las emisiones de gases de efecto invernadero medidos en equivalentes de CO2. Así, por ejemplo, el sector emite el $37 \%$ del metano antropógeno, el cual proviene en su mayor parte de la fermentación entérica de los rumiantes. Produce el $65 \%$ del $\mathrm{N}_{2} \mathrm{O}$ antropógeno, en su mayor parte proveniente del estiércol (Steinfeld et al., 2006)

Las medidas tomadas al respecto de los efectos locales y regionales, se han orientado a la preservación de los recursos naturales que son base del sistema productivo. En 2008 se aprueba el Decreto № 405/008 “Uso responsable y sostenible de los Suelos" y la Ley № 18.564 "Conservación, uso y manejo adecuado de las aguas" con el fin de asegurar el correcto uso de los recursos en todas las actividades rurales. Esta normativa contempla riesgos como la erosión, fertilización excesiva, cobertura del suelo, uso de agroquímicos y vertidos de efluentes, pero no considera otros factores como la sobrecarga ganadera o el sobrepastoreo de praderas naturales.

En algunos sistemas particulares como la producción lechera, donde existe mayor concentración de animales, el MGAP a través de su Proyecto de Producción 
Responsable genera el "Manual para el manejo de Efluentes de Tambo" con el fin de orientar la conducción, almacenaje y disposición final de estos residuos (PPRMGAP, 2008).

En relación a los aspectos de alcance global, en 2009 se crea el Sistema Nacional de Respuesta al Cambio Climático y una Unidad dentro de la Dirección Nacional de Medio Ambiente, que será responsable del cumplimiento de los compromisos nacionales sobre la materia en la Convención Marco de las Naciones Unidas sobre el Cambio Climático (SNRCC, 2011). Este programa incluye aspectos de mitigación a través de la reducción de emisiones y captura de carbono, como también adaptación a las consecuencias del cambio climático.

Más allá de las medidas que se han adoptado y aunque el sector ganadero uruguayo se encuentre en fase de adaptación a las exigencias internacionales, existe margen de mejora en las prácticas realizadas y técnicas aplicadas a la producción.

En la ganadería extensiva, los aspectos ambientales más relevantes son las emisiones de metano y los efectos sobre la biodiversidad y productividad de las pasturas naturales que son la base nutricional de la actividad. Para ello, entre otras medidas que pueden surgir de la investigación en proceso, un ajuste de la carga, reduciendo las presiones de pastoreo, resultaría en un mayor secuestro de carbono en la masa radicular y la materia orgánica del suelo, así como una mejora en la biodiversidad de sistemas extensivos de pastoreo (Witt et al., 2011). No obstante en la región se evidencia el efecto de cargas ganaderas superiores a las deseables para el óptimo funcionamiento del sistema (Nabinguer et al, 2011).

Para los nuevos sistemas de producción con mayor grado de intensificación como los de engorde de bovinos en corral, la Producción lechera y la producción de 
monogástricos como cerdos y aves, la normativa y las acciones oficiales deberán actualizarse para ajustarse a las necesidades de protección ambiental y el aumento de los volúmenes de producción.

En muchos aspectos, existen vacíos de información o necesidades de profundización que requieren de una continua actualización de información científica generada a nivel internacional y a nivel nacional.

\subsection{Contribución de la investigación a la consecución de estos objetivos}

\subsubsection{Marco general}

Como se ha mencionado anteriormente, los grandes desafíos de la ganadería son en general compartidos por el sector a nivel global. En este sentido el interés social por la seguridad alimentaria, el medio ambiente y el bienestar animal comenzó a tener fuerte presencia en las demandas de productos de origen animal en los principales países consumidores. En respuesta a los cambios en la sociedad y por lo tanto en el mercado, las industrias animales necesitan ser "limpias, verdes y éticas" lo que requiere la minimización del uso de drogas, químicos y hormonas, reducir el impacto ambiental y evitar las prácticas que comprometen el bienestar animal (Martin, 2009).

La situación del estado del conocimiento científico y su relación con la aplicación práctica en la ganadería y la formulación de políticas no son necesariamente similares en los temas medioambientales y aquellos relacionados con el bienestar animal.

En lo que respecta a bienestar animal, la disponibilidad de información se ha incrementado sustancialmente en tiempos recientes y ello brinda insumos 
importantes para la generación de políticas en la materia. A modo de ejemplo, la Autoridad Europea de Seguridad Alimentaria, responsable entre otras cuestiones, de elaborar informes y opiniones sobre bienestar animal, basa gran parte de sus documentos en información proveniente de artículos publicados en revistas científicas (Le Neindre, 2009). No obstante, muy poca de la información científica generada se traslada a medidas concretas de manejo al ámbito productivo del sector ganadero (Grandin, 2003).

En el caso del efecto de la ganadería sobre el medio ambiente, la tendencia moderna es hacia la utilización de indicadores complejos que integran información de varios componentes o propiedades ambientales de los sistemas a nivel de granja o de regiones, como la cuenta verde, evaluación del ciclo de vida de los productos, la huella ecológica, entre otros (Halberg et al, 2005). La construcción de estos índices se desarrolla con la medición de determinados parámetros ambientales que son el resultado de la integración de mucha información generada por investigaciones a nivel global, por ejemplo ciclo de los nutrientes en especial $\mathrm{N}$ y $\mathrm{P}$, contaminación de aguas, emisiones, pérdida de diversidad biológica, etc. Las investigaciones han sido muy diversas, pero los grandes focos de la investigación en las últimas décadas han estado referidos al tratamiento y disposición de efluentes (Burton and Turner, 2003), el nitrógeno en sus diversas formas como contaminante de suelos y aguas (De Jong et al., 2009) y las emisiones gaseosas, en particular aquellas que promueven el efecto invernadero (Garnett, 2009). Este último tema, por su alcance global, ha propiciado la generación de organismos científicos de nivel internacional como el Panel Intergubernamental para el Cambio Climático (IPCC) el cual, entre otras cosas, ha procurado estandarizar factores de emisión para los diferentes sistemas de producción. No obstante, no existe consenso en algunos ítems involucrados 
como el potencial de calentamiento global del metano, el carbono de corto plazo de retención, las emisiones de $\mathrm{CO}_{2}$ por uso y cambio de uso de la tierra y la atribución directa de algunas emisiones a la ganadería (Herrero et al., 2011).

En resumen, se constata un gran crecimiento en la producción científica en materia de bienestar animal y medio ambiente, no obstante, la información ha sido generada mayoritariamente en países del hemisferio norte, siendo sensiblemente menor la información generada en los sistemas de producción en los países latinoamericanos, existiendo algunos sistemas de producción diferentes a los predominantes en el resto del mundo que requieren generación de conocimiento propio. A modo de ejemplo, en la figuar 2 puede verse la proporción de artículos científicos publicados en la categoría Ciencia Animal en el área Agricultura, comparando América Latina con Europa occidental y Norteamérica.

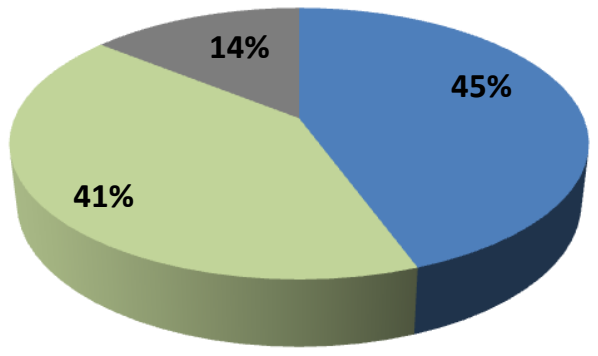

Europa Occidental $\square$ Norte América $\square$ América Latina

Figura 2 - Porcentaje de artículos científicos publicados en la categoría Ciencia Animal en el área de Agricultura en el período 1996 a 2010 (SJR, 2012).

En estos momentos, Uruguay está atravesando una etapa de reestructuración y adecuación de los planes institucionales para enfrentar los comentados desafíos 
de la producción. Tanto los planes de acción de cada institución, como la interacción entre las mismas generan nuevos componentes y líneas estratégicas. En el área de la producción animal, en 2008 se firmó un acuerdo interinstitucional para la elaboración de un "Plan Nacional de Investigación en Salud Animal" (Planisa), de donde surgió un equipo técnico independiente para el estudio de las prioridades nacionales. Entre las recomendaciones técnicas de orden general surgidas de este equipo, se establece que el bienestar animal y el medio ambiente cortan transversalmente a todas las cadenas de producción y deberían ser especialmente contemplados en los proyectos futuros (INIA, 2011). No obstante, existe una disparidad en el grado de conocimiento de la problemática entre los diferentes agentes de las cadenas comerciales, así como a nivel de los diferentes sistemas. Para un país como Uruguay, es necesario una investigación aplicada con un enfoque integral de bienestar animal, inocuidad de productos e impacto ambiental, así como aspectos éticos, sociales y culturales (Montossi y del Campo, 2007).

\subsubsection{La investigación realizada en Uruguay hasta la actualidad}

\subsubsection{Bienestar animal}

La investigación nacional en bienestar animal y etología aplicada en animales de producción, tiene una historia reciente y ha sido desarrollada principalmente en la Universidad de la República (UDELAR) e INIA, pero también han realizado actividades, el Instituto Plan Agropecuario (IPA) e INAC (Huertas, 2010). Los sectores de la producción en los que se ha priorizado la investigación en INIA han sido la cría y el engorde de bovinos de carne, bovinos de leche, ovinos, cerdos y conejos, así como en temas relacionados al transporte y sacrificio en bovinos y ovinos (Blumetto et al., 2008). 
En bovinos de engorde uno de los temas priorizados por la investigación a nivel nacional, es el manejo relacionado al transporte y pre sacrificio. Al respecto se destacan:

- las lesiones durante las operaciones de clasificación, identificación y embarque por mal manejo del personal

- la disponibilidad de agua de bebida y abrigo de las condiciones meteorológicas

- diseño y mantenimiento de las instalaciones de embarque, especialmente evitando la existencia de objetos punzantes o cortantes

- dimensiones, condición y densidades de animales en los camiones de trasporte

- Heridas y golpes causados por caídas o animales astados

Los perjuicios económicos derivados de estas causas han sido cuantificados en varios millones de dólares en donde interviene los hematomas y las pérdidas por carnes con pH elevado (Barros, 2007). Ha sido estudiado el transporte en su relación con el bienestar de los animales y características de la canal, detectando algunas prácticas de manejo del momento del embarque de los animales, durante el transporte y también la duración y manejo de la espera en los corrales previo al sacrificio (del Campo et al., 2010; Huertas et al., 2010).

El estrés térmico puede ser un factor importante en los sistemas pastoriles de engorde en los meses de verano y por ese motivo, el suministro de fuentes de sombra, natural y artificial, ha sido estudiado determinando su relevancia como medida de mejora del bienestar de los animales (Rovira y Velazco, 2010; Rovira y Velazco, 2011) 
En la fase reproductiva han sido priorizados los estudios referentes al destete, haciendo hincapié en la reducción del estrés que éste produce tanto en terneros como en vacas, y comparando distintas alternativas como el destete utilizando tablillas nasales con permanencia de terneros y vacas juntos, destete con separación a través de una cerca que permite el contacto visual o destete con separación total; sin embargo no se han obtenido diferencias claras desde el punto de vista del estrés de los animales y su comportamiento productivo (Enríquez, et al., 2010). Con respecto a estas prácticas de manejo se han realizado investigaciones analizando la influencia sobre el comportamiento e indicadores fisiológicos en destete precoz (Ungerfeld, et al., 2011).

En el caso de los ovinos, algunas técnicas para el manejo reproductivo como la extracción de semen con electroeyaculador han sido estudiadas y se ha comprobado su efecto de estrés agudo sobre los carneros (Damián y Ungerfeld, 2011).

En el caso de monogástricos el desarrollo de la investigación es aún más incipiente, con proyectos en marcha para la evaluación de bienestar en cerdas reproductoras en sistemas de producción extensivos (Vadel et al., 2005) y los primeros trabajos de caracterización de sistemas intensivos y extensivos desde el punto de vista etológico (Blumetto et al., 2011). En producción de conejos se han realizado estudios relacionados al comportamiento maternal, con test de elección de materiales de cama para los nidos (Blumetto et al., 2010).

En el caso de bovinos de leche se ha realizado un diagnóstico a nivel de establecimientos comerciales para identificar posibles problemas de bienestar en los diferentes sistemas de producción. Aplicando la metodología de Welfare Quality $^{\circledR}$, se realizaron medidas basadas en los animales lecheros, incluyendo condición corporal, cojeras, lesiones en piel y/o mucosas, inflamación, presencia 
de diferentes enfermedades, la incidencia de conducta agonística, distancia para evitar acercarse a un humano, suciedad de miembros y/o ubres, el tiempo necesario para descansar, el porcentaje de animales que se golpean con las instalaciones al echarse o acostarse, mutilaciones rutinarias tales como descorne, corte de cola, etc. (Huertas et al, 2012). Del estudio surge la recomendación de trabajar sobre aspectos relacionados al trato de los animales por parte del personal y las áreas de descanso de los animales.

Existen varios proyectos de investigación en curso, por lo que en el futuro próximo se verá incrementada la disponibilidad de información publicada.

\subsubsection{Medio ambiente}

Dadas las características extensivas de los sistemas de producción predominantes, el estatus ambiental puede considerarse bueno en términos generales (Oyhantcabal, 2010). Sin embargo, por la importancia territorial de la producción agropecuaria, ésta es también la principal fuente de impacto ambiental. La investigación nacional en relación a los impactos ambientales de la ganadería ha sido escasa debido a la naturaleza de los principales sistemas de producción.

En sectores como el lácteo, aunque la base del sistema es pastoril, la concentración de animales es mayor y se incrementan los problemas ambientales. Existe la percepción por parte de los agentes del sector que ha existido un esfuerzo en la investigación al respecto pero aún quedan algunos temas pendientes (Nozar, 2007). Sin embargo, es muy poco lo publicado en estos temas por parte de investigadores nacionales, aunque existen proyectos de investigación en marcha y los resultados preliminares han sido presentados en congresos y jornadas técnicas. En este tema el INIA ha realizado balance de nutrientes para sistemas lecheros con diferentes grados de intensificación, obteniendo balances 
de 7,67 a 32,55 kg de $\mathrm{N}$ por hectárea y $-7,59$ a 72,09 de $\mathrm{P}$, para los sistemas menos y más intensivos respectivamente (Lamanna y Durán, 2008). Se estimó que anualmente se incorporan entre 100 y $300 \mathrm{~kg}$ de $\mathrm{N}$ por hectárea que exceden las necesidades de los cultivos y la capacidad del suelo para retenerlo, a lo cual se suma que tan solo el 5 a 15\% de las deyecciones se producen en la sala de ordeño, lo que permitiría su conducción y procesamiento (Viñas y Gutiérrez, 2008).

En el caso de la producción bovina de carne con base pastoril y suplemento de granos, se realizó un balance de nutrientes para 36 predios comerciales, determinando balances de $\mathrm{N}$ entre 7,6 y $213,0 \mathrm{~kg} / \mathrm{há}$ y $\mathrm{P}$ entre $-1,7$ y $24,8 \mathrm{~kg} / \mathrm{há}$ (Tieri et al, 2011). A nivel de engorde de bovinos a corral se ha procurado determinar el potencial de contaminación de estos sistemas, observándose que existió lixiviación de $\mathrm{NO}_{3}$ en profundidad. A su vez, los elevados valores de $\mathrm{P}$ en la superficie del suelo sumado a la resistencia a la penetración mostrada por el mismo, serían condiciones en las cuales las pérdidas de este nutriente por escurrimiento podrían ser importantes y por lo tanto su potencial contaminante de aguas superficiales. (Ciganda y La Manna, 2011).

En este sentido, ya han sido estudiados algunos efectos de la actividad ganadera sobre aguas en cursos loticos (Chalar et al., 2011) e incluso agua de lluvia (Zunckel et al., 2003).

Mas allá de los aspectos mencionados, recientemente el tema excluyente en todos los foros de ganadería en el país, son los aspectos relacionados con el cambio climático y más específicamente con la emisión de gases de efecto invernadero (Chouy et al., 2010). En este sentido, en Uruguay se corrobora que cuando se utilizan menos insumos, se obtiene menor producción por hectárea, pero con un impacto ambiental reducido. Sin embargo, al comparar las emisiones de gases de efecto invernadero (GEI) por kilogramo producido de carne bovina, 
los resultados muestran que los sistemas intensivos aumentan la producción y las emisiones totales, pero éstas se reducen por kilogramo de producto (Becoña y Wedderburn, 2010).

En relación a las emisiones de GEI proveniente de la ganadería la investigación se encuentra en etapas iniciales, mayoritariamente tendiendo a la determinación de emisiones de metano en diferentes sistemas ganaderos. La Universidad de la República ha estimado la emisión de metano y óxido nitroso de sistemas pastoriles y confinados de bovinos de carne, estimando los diferentes orígenes: entérico, de deyecciones, cultivos y también la fijación de carbono por parte del suelo (Modernel et al, 2010; Modernel et al, 2011). En otros estudios se determinaron los factores de emisión para ganado de carne y lechero para las siete zonas agro-ecológicas del país utilizando métodos Tier-2 de la metodología IPCC (Irisarri et al, 2008).

También se estimaron las emisiones de gases de efecto invernadero en tres sistemas ganaderos de engorde intensivo de bovinos "feedlot", pasturas sembradas + suplementación y campo natural. Se utilizó información de productividad validada para Uruguay, considerando las emisiones del animal (fermentación entérica y manejo de estiércol), de la producción de alimentos y del suelo, utilizando la metodología del IPCC (Modernel et al., 2011).

Sin embargo, en todos los casos se trata de estimaciones con valores por defecto y solo recientemente se han comenzado a realizar mediciones de emisiones de metano a través de la técnica de trazado por hexafluoruro de azufre (SF6) para la cuantificación de las emisiones de $\mathrm{CH}_{4}$ en vacas en pastoreo (Dini et al., 2011). 
Por lo expuesto, la investigación en estos temas para la comunidad científica nacional presenta un panorama de un amplio abanico de oportunidades y demandas de generación de conocimiento.

\subsubsection{Oportunidades para la investigación en el futuro próximo}

Atendiendo a la creciente demanda de información en todas las disciplinas que involucra la producción pecuaria, las instituciones nacionales de investigación planifican sus estrategias para enfrentar dicha demanda. En los siguientes puntos se realiza un análisis de las oportunidades para la generación de conocimiento en materia de bienestar animal y medio ambiente.

\subsubsection{Bienestar animal}

El Centro colaborador de la OIE para el bienestar animal, realizó un análisis de las principales grandes líneas futuras de investigación para el bienestar animal en las Américas (Huertas, 2010):
a) Bienestar animal (BA), sustentabilidad y sistemas extensivos de producción
b) Continuar con la evaluación del BA en animales de producción
c) Análisis de riesgos en $\mathrm{BA}$
d) Control de poblaciones de perros vagabundos
e) Continuar trabajando en BA en animales de laboratorio
f) Bienestar animal y adaptación al cambio climático.

Sin duda, para la realidad uruguaya las líneas determinadas en los puntos a, b, c y f serán las que concentren la mayor parte de los esfuerzos de investigación en el futuro cercano. 
Los grandes aspectos de la evaluación del bienestar animal son universales y con altos niveles de consenso a nivel internacional. A modo de ejemplo, los protocolos de evaluación de bienestar a nivel de granjas establecido por el Welfare Quality Proyect, validado en Europa y Sudamérica, contemplan cuatro principios básicos: buena alimentación, entorno adecuado, buena salud y comportamiento apropiado (Welfare Quality ${ }^{\circledR}$, 2009). Los criterios utilizados reúnen una combinación de evaluaciones cuantitativas y cualitativas o basados en el ambiente y en los animales, lo cual implica un compromiso entre evaluaciones objetivas y subjetivas que intentan estandarizarse mediante entrenamiento de los evaluadores.

El establecimiento de la mayor cantidad posible de criterios objetivos y la validación de los subjetivos es el gran desafío a nivel de la investigación.

No se cuenta con suficiente información en aspectos relacionados a la disponibilidad de espacio tanto a nivel de granja como en los corrales de espera de matadero, las agresiones entre animales para procurar su reducción, los sistemas alternativos de alojamiento, los tiempos de transporte y espera pre sacrificio, el efecto de algunas intervenciones como la castración y el descolmillado y también algunas condiciones generales de manejo (Barnett, 2007). Asimismo, destaca los aspectos en relación al entrenamiento de las personas que manejan los animales y la producción de información accesible a los consumidores y a la sociedad en general.

El abordaje de la medición del bienestar es complejo y en general requiere un enfoque multidisciplinar, que incluiría mediciones de productividad, fisiología, comportamiento, salud e inmunidad y sentimientos de los animales (McGlone, 2001). Sin embargo, estos criterios no son totalmente independientes y en muchos casos están estrechamente relacionados. Por esa razón, sin perjuicio de 
que otros enfoques sean utilizados, existen tres grandes formar de abordar esta medición: la productividad y características asociadas a los productos, indicadores fisiológicos y de estrés e indicadores de comportamiento.

La evaluación de la productividad como indicador de bienestar es muy práctica ya que involucra la toma de datos que son frecuentemente registrados en los sistemas de producción a nivel de granja (Bennet, et al., 2000). Por ejemplo, ha sido demostrada una asociación entre aumento de productividad y enriquecimiento ambiental (Lyons et al., 1995) o un empeoramiento de la productividad y un pobre bienestar cuando ciertas rutinas de manejo generan temor de los animales a los granjeros (Hemsworth, 2003).

Sin embargo, aunque un bajo nivel de productividad o deterioro en la calidad de producto podrían estar manifestando la existencia de un pobre bienestar animal, una productividad adecuada no siempre implica la ausencia de problemas de bienestar.

En cuanto a indicadores fisiológicos, la medición de algunas sustancias como cortisol, corticosterona, catecolaminas y otras hormonas y compuestos bioquímicos, dan buena información sobre el bienestar de los animales (Broom, 1991). Un enfoque clásico para la medición del bienestar es mediante la actividad del eje hipotálamo-hipófisis-adrenal, sin embargo la variabilidad de la misma en función de múltiples factores y la influencia de la manipulación para la toma de muestras de sangre, hace que se haya comenzado el estudio de alternativas para su determinación, como por ejemplo en heces, saliva u orina (Mormède et al., 2007).

Otro tipo de sustancias bioquímicas, como hormonas reproductivas, neurotransmisores, enzimas y otros productos metabólicos también pueden ser 
usados para evaluar bienestar, por ejemplo kreatin kinasa, alkalino fosfatasa, glucosa, etc. (Broom y Jhonson, 1994). Recientemente, sin embargo rara vez se utilizan mediciones productivas o fisiológicas sin un contraste con variables etológicas.

Por otro lado, el comportamiento es una de las manifestaciones más evidente del estado de bienestar de los animales y es un área donde aún quedan importantes vacíos de conocimiento ya que éste depende de las especies, las razas, temperamento individual, el sistema productivo y factores humanos relacionados al manejo (Paranhos da Costa, 2011). Entre las múltiples dimensiones del estudio del comportamiento, existen algunos aspectos que son prioritarios en los sistemas de producción intensivos, en los cuales los animales generalmente se concentran en poca superficie. Algunos son muy relevantes como los aspectos de comportamiento anormal y su relación con procesos patológicos (Broom, 2006) y el comportamiento social agonístico y el efecto de las agresiones (Stukenborg et al., 2011). El enriquecimiento ambiental ha sido una de las técnicas de manejo más utilizadas para permitir a los animales la expresión de los rasgos característicos de su comportamiento en sistemas intensivos. Sin embargo, aún hay poca información de por qué y cómo actúan las técnicas utilizadas sobre el bienestar de los animales (van de Weerd y Day, 2009).

En los sistemas extensivos, en cambio, aparecen como importantes, aspectos relacionados con la docilidad de los animales y la relación humano-animal en el manejo (Huber et al., 2008). El gran desafío para los investigadores, en la situación actual de la ganadería uruguaya, es entender a los animales y su interacción con el ambiente. Para ello se debe comprender el comportamiento, las bases motivacionales de los mismos y la fisiología, a todos los niveles organizativos, desde los patrones espaciales y sociales de un grupo de animales en pastoreo, 
hasta los neurotransmisores involucrados en dichos procesos (del Campo, 2008). Existen otras cuestiones que pueden afectar el bienestar, como por ejemplo el temperamento de los animales (del Campo et al., 2010), lo cual abriría una nueva perspectiva para la mejora del bienestar a través de la selección de líneas o razas por temperamento e incluso la selección genética para animales más tranquilos.

La caracterización etológica de los diferentes sistemas de producción así como la respuesta fisiológica de los animales involucrados es fundamental para poder abordar un enfoque integral, asociando esta disciplina con aspectos productivos y las consecuencias ambientales de la utilización de las diferentes prácticas de manejo.

\subsubsection{Protección del medio ambiente}

En el Plan estratégico del INIA para el período 2011-2015 se recogen las líneas estratégicas del MGAP, en los cuales se plantea ampliar las capacidades de investigación y capacitación, para reducir los riesgos de pérdidas de los recursos naturales y apostar a su preservación. Por su parte, el Gabinete de la Innovación integrado por cuatro ministerios, prioriza una serie de temas en medio ambiente y tecnologías ambientales (INIA, 2011), entre las cuales se destacan:

- generación de indicadores de impacto ambiental y mejora en los procesos productivos

- certificación de procesos

- estrategias de uso a nivel de cuencas hidrográficas

- cuantificación del consumo energético en los sistemas productivos.

A nivel de los aspectos que hacen a los impactos locales o regionales, una prioridad es el estudio de los efectos sobre las fuentes de agua, en especial en cuencas donde se concentran sistemas más intensivos. En este sentido, la 
capacidad del suelo y el ecosistema en general para la captura y utilización de los nutrientes y el efecto sobre los ecosistemas acuáticos no son suficientemente conocidos. La eventual intensificación de la producción bovina de carne, con la utilización de los sistemas de engorde en corrales, demandaría conocer la dinámica de los nutrientes dentro del sistema con sus pérdidas y la incorporación de los efluentes a los sistemas agrícolas, de modo de conocer el riesgo potencial de contaminación para aguas superficiales y subterráneas.

Una situación similar podría inferirse para los sistemas de producción porcina intensiva, aunque los sistemas más extensivos podrían estar en una situación similar a la producción lechera, con una distribución de las deyecciones en áreas de pasturas lo que disminuiría la concentración, pero con una alta incidencia de insumos exógenos al sistema. Esto implica conocer la capacidad del suelo y la pastura para el reciclaje de los nutrientes, ajustar las cargas de animales por unidad de superficie y conocer el comportamiento de los animales que afectan el patrón de distribución de nutrientes en el sistema.

La emisión de amoníaco puede ser muy relevante desde el punto de vista cuantitativo en el balance de nitrógeno en sistemas de producción intensivos (Calvet et al., 2008), pudiendo afectar a un entorno territorial amplio fuera del sistema emisor. Existe poca información sobre emisiones de $\mathrm{NH}_{3}$ en las condiciones de los sistemas de producción uruguayos, su importancia en el balance de nitrógeno, los ciclos de deposición y sus efectos sobre la matriz territorial circundante. En general se asume que el efecto de dispersión es importante, en base a las relativamente escasas fuentes de emisión y una gran capacidad de captación de nitrógeno por parte de las pasturas naturales. Sin embargo, no ha sido debidamente cuantificado y podría presentar problemas 
ambientales en algunas regiones de mayor concentración de la ganadería intensiva.

Para la ganadería extensiva desarrollada sobre pasturas naturales, existe aún una brecha importante de productividad con correcto manejo, atendiendo a la importante función ecológica de estos ambientes, como son la conservación de la biodiversidad y la provisión de servicios ecosistémicos (Carvalho et al., 2011).

Asimismo, los efectos ambientales de escala global son por los que el país recibe presiones internacionales, particularmente la emisión de gases de efecto invernadero. En este sentido, es prioritaria una caracterización de los sistemas y la generación de factores de emisión adecuados a los mismos. Se deben evaluar los impactos de la ganadería desde diferentes ángulos, ya que los sistemas extensivos resultan muy perjudicados si solo se consideran las emisiones por $\mathrm{Kg}$ de carne producida. En cambio, debería realizarse un análisis de riesgo en cada etapa de la intensificación, considerarse el balance total de carbono en el sistema de producción, el ciclo de vida de los productos, la calidad de agua el uso de agroquímicos y proporcionar a los consumidores información detallada al respecto (Becoña y Wedderburn, 2010).

Aunque el contexto actual presiona sobre las emisiones de GEI como efecto ambiental de la ganadería, no debe perderse de vista que existe un efecto ya evidente del cambio climático. En tal sentido se han registrado un incremento de las precipitaciones y una reducción en el número e intensidad de heladas (Giménez et al., 2008) y por tanto deben considerarse como temas emergentes de alta importancia la adaptación al cambio climático, el cuidado de suelos y aguas, y el mantenimiento de los servicios ecosistémicos y la biodiversidad (Oyhantcabal, 2010). 


\section{Objetivos y estructura de la tesis}

Como ha sido descrito, la ganadería de la región del Mercosur en general y la uruguaya en particular, se enfrentan a una gran cantidad de desafíos, entre los cuales destacan el bienestar animal y las implicaciones ambientales de los diferentes sistemas de producción. En este contexto, debería existir un aporte importante desde el sistema nacional de investigación para la reducción de las lagunas de conocimiento en la materia. Precisamente, el presente trabajo tiene como meta contribuir al mejor conocimiento de los sistemas propios del Mercosur, lo que proveerá de información para la futura formulación de alternativas productivas sustentables. Para ello se determinaron cinco objetivos específicos de investigación:

1) Caracterizar tres diferentes sistemas de producción de terneros con destino a la producción de carne desde el punto de vista productivo y evaluar su influencia sobre el comportamiento.

2) Identificar, en dichos sistemas, factores derivados del comportamiento social e indicadores fisiológicos que puedan indicar problemas de bienestar.

3) Caracterizar dos sistemas de producción de cerdos (intensivo y al aire libre) muy divergentes desde el punto de vista productivo, de comportamiento y de los factores fisiológicos que podrían ser utilizados como indicadores de bienestar.

4) Evaluar el efecto de dichos sistemas sobre algunos parámetros de calidad de producto.

5) Describir la dinámica de los macro-nutrientes en el sistema de producción de cerdos a campo y su relación con algunos aspectos de comportamiento. 
Para ello, la presente tesis se ha estructurado en seis capítulos.

En el primer capítulo, se realiza una introducción general, que presenta una aproximación a la importancia, las características y los desafíos presentes y futuros de la ganadería en el Mercosur, con énfasis en la realidad de Uruguay. Se analiza el rol de la investigación en el apoyo al sector ganadero en los desafíos que se le presentan en un futuro próximo.

El segundo capítulo está relacionado con el primer objetivo y pretende realizar una caracterización a través del comportamiento de terneros Holstein criados en tres diferentes sistemas. Uno, es el sistema tradicional de engorde exclusivamente a pasturas, otro representa a los nuevos sistemas emergentes con animales confinados con suministros de forrajes y granos producidos fuera del sistema, y por último un sistema intermedio que combina el confinamiento, la inclusión de insumos exógenos y el pastoreo por horas. Se analiza la evolución diaria del uso del tiempo y la relación de los diferentes comportamientos con el sistema de producción y las condiciones climáticas.

El tercer capítulo, atendiendo al objetivo 2, está basado en los mismos tres sistemas de producción y procura la caracterización productiva con una evaluación de crecimiento y de la eficiencia de uso de los recursos en los diferentes sistemas. Para tener un estimador del estado de bienestar de los animales, se estudia el comportamiento social, registrando tanto las interacciones positivas entre individuos como el comportamiento agonístico y se analiza la concentración en la sangre de una serie de indicadores fisiológicos. Estos indicadores son sustancias bioquímicas que están relacionados con respuestas a estrés, daños físicos, procesos metabólicos o estado de salud, por lo cual son una herramienta para la identificación de eventuales problemas de salud y/o bienestar animal. 
El capítulo cuarto tiene relación con el objetivo 3 y está dedicado a dos contrastantes sistemas productivos de cerdos, uno de ellos es un engorde tradicional con animales confinados en una nave de ventilación natural y el segundo un sistema de engorde a campo con alimentación ad libitum y acceso a pasturas. Se realiza un análisis productivo y de eficiencia alimentaria y se realizan estudios de comportamiento para establecer una pauta de patrones generales de uso del tiempo. Se analiza el comportamiento social agonístico, comparando ambos sistemas, utilizando una escala que permite evaluar la intensidad de las agresiones y su frecuencia. Se realizan determinaciones de una serie de bioquímicas en el suero sanguíneo como indicadores fisiológicos de estrés y salud general para la etapa de producción y en matadero. Para el cumplimiento del objetivo 4, se analiza la influencia del sistema de producción en algunos parámetros de carcasa y calidad de carne, con énfasis en la composición lipídica.

El quinto capítulo atiende al objetivo 5 y para ello se realizaron dos ensayos en años diferentes con diseños similares con cerdos en fase de recría-finalización. En el mismo se realiza un estudio de la dinámica de los nutrientes, con énfasis en nitrógeno y fósforo. Se aplican diferentes metodologías de campo como el muestreo periódico de suelo para determinar concentración de nutrientes, la utilización de cámaras estáticas para la estimación de emisiones de amoníaco y bandejas de escurrimiento superficial para la determinación del arrastre de nutrientes por parte del agua de lluvia.

Finalmente, en el capítulo 6 se resumen los resultados más importantes obtenidos en ambas especies para los diferentes sistemas y se realiza una discusión general con una perspectiva integrada de los resultados y sus consecuencias en el ámbito de la producción. Como etapa final se propone un análisis de la temática considerada prioritaria para el desarrollo de futuras investigaciones. 


\section{Referencias}

Barnett, J. L. (2007). Effects of confinement and research needs to underpin welfare standards. Journal of Veterinary Behavior: Clinical Applications and Research 2(6), 213-218.

Barros, A. y Castro, L. (2004) Bienestar Animal: Buenas prácticas operacionales. Serie Técnica № 34. Instituto Nacional de Carnes. 63pp.

Barros, A. (2007) El Bienestar Animal aplicado al transporte y la faena para consumo humano. REDVET. Revista electrónica de Veterinaria VIII (12B). 1-29.

BCU (2011) Estadísticas e indicadores del Banco Central del Uruguay: Intercambio Comercial. http://www.bcu.gub.uy/Estadisticas-eIndicadores/Paginas/Intercambio -Comercial-.aspx

Becoña, G. y Wedderburn, L. (2010). Comparación del impacto ambiental en relación a gases de efecto invernadero en sistemas ganaderos de Uruguay y Nueva Zelanda. Edición: Agresearch y Plan Agropecuario. 2020 SCIENCE 1, Pag. 49-62. Montevideo, Plan Agropecuario.

Bennett, R., Henson, S., Harper, G., Blaney, R. y Preibisch.K. (2000). Economic evaluation of farm animal welfare policy: baseline study and framework development. Final Report The Ministry of Agriculture, Fisheries and Food. The University of Reading, pp. 1-134. Reading.

Blumetto, O., Ayala, W., Banchero, G., De Barbieri, I., del Campo, M., Luzardo, S., Quintans, G., Viñoles, C. y Montossi, F. (2008). El Bienestar Animal en las lineas de trabajo del Instituto Nacional de Investigación Agropecuaria de Uruguay. Congreso de Bienestar Animal. LATU. Montevideo, Uruguay. 
Blumetto O., Olivas I., Torres A.G. y Villagrá A. (2010). Use of straw and wood shavings as nest material in primiparous does. World Rabbit Science18 (4) 237242.

Blumetto O., Villagrá A. y Torres A.G., (2011). Pautas de comportamiento y bienestar, en cerdos engordados en confinamiento o a campo. XXII Reunión Latinoamericana de Producción Animal (ALPA) 24 al 26 de octubre de 2011, Montevideo, Uruguay. Sección C (4).

Bolhuis, J. E., Schouten, W. G. P., Schrama, J. W. y Wiegant, V. M. (2005). Behavioural development of pigs with different coping characteristics in barren and substrate-enriched housing conditions. Applied Animal Behaviour Science 93(3-4), 213-228.

Broom, D. M. (2006). Behaviour and welfare in relation to pathology. Applied Animal Behaviour Science 97(1), 73-83.

Broom, D. M. y Johnson, K. G. (1993). Stress and animal welfare. Editors: Chapman \& Hall. London, pp. 1-207.

Brown-Brandl, T. M., Eigenberg, R. A., Nienaber, J. A. y Hahn, G. L. (2005). Dynamic Response Indicators of Heat Stress in Shaded and Non-shaded Feedlot Cattle, Part 1: Analyses of Indicators. Biosystems Engineering 90(4), 451-462.

Burton, C. H. y Turner, C. (2003). Manure Management: Treatment strategies for sustainable agriculture.2, Lister \& Durling Printers,. Silsoe, Bedford, UK, pp. 1451.

Calvet, S., Estellés, F., Hermida, B., Blumetto, O. y Torres, A. (2008). Experimental balance to estimate efficiency in the use of nitrogen in rabbit breeding. World Rabbit Science 16(4), 205-211. 
Cambra-López, M., Aarnink, A. J. A., Zhao, Y., Calvet, S. y Torres, A. G. (2010). Airborne particulate matter from livestock production systems: A review of an air pollution problem. Environmental Pollution 158(1), 1-17.

Carrere, R. (2002) Uruguay: ¿qué es lo que está certificando el FSC?. Boletín del Movimiento Mundial por los Bosques tropicales 64(1), 7-9.

Carvalho, P. C. F., Nabinger, C., Lemaire, G. y Genro, T. C. M. (2011). Challenges snd opportunities for livestock production in natural pastures: the case of Brazilian Pampa Biome. IX International Rangeland Congress - Diverse Rangelands for a Sustainable Society, 1[1], IX-XV. Rosario, INTA - AAMPN. 2-42011.

Castro, L. (2007). El bienestar animal en Uruguay: Acciones y estrategias. Congreso Internaciobal de Bienestar Animal, 1. Montevideo, INIA. 25-4-2007.

Ciganda, V. y La Manna, A. (2011). Potencial de contaminación de los sistemas intensivos de engorde bovino en corrales sobre tierra. Sitio Argentino de Producción animal, Sustentabilidad Agropecuaria (116), pp. 1-6. http://www.produccion-animal.com.ar/.

Chalar, G., Arocena, R., Pacheco, J. P. y Fabián, D. (2011). Trophic assessment of streams in Uruguay: A Trophic State Index for Benthic Invertebrates (TSI-BI). Ecological Indicators 11(2), 362-369.

Chouy, J., Lussich, N. y Jiménez de Arechaga, P. (2010). El impacto ambiental de la ganadería. El País Agropecuario, El País - Seragro, 190, pp. 24-27. Montevideo. 29-12-2010. 
Colombres, M. (2010). 18o Congreso Mundial de la Carne: El Mercosur asoma como lider. Sitio Argentino de Producción animal. Buenos Aires http://www.produccion-animal.com.ar/informacion_tecnica/origenes_ evolución_y_estadisticas_de_la_ganaderia/89-Congreso.pdf

Damián, J. P. y Ungerfeld, R. (2011). The Stress Response of Frequently Electroejaculated Rams to Electroejaculation: Hormonal, Physiological, Biochemical, Haematological and Behavioural Parameters. Reproduction in Domestic Animals 46(4), 646-650.

De Jong, R., Drury, C. F., Yang, J. Y. y Campbell, C. A. (2009). Risk of water contamination by nitrogen in Canada as estimated by the IROWC-N model. Journal of Environmental Management 90(10), 3169-3181.

del Campo, M. (2008). El Bienestar animal y la calidad de carne de novillos en Uruguay con diferentes sistemas de terminación y manejo previo a la faena. Tesis Doctoral , -197. Valencia, Universidad Politécnica de Valencia.

del Campo, M., Brito, G., Soares de Lima, J., Hernández, P. y Montossi, F. (2010). Finishing diet, temperament and lairage time effects on carcass and meat quality traits in steers. Meat Science 86(4), 908-914.

DIEA. (2003) La ganadería en Uruguay, contribución a su conocimiento. MGAP. Montevideo. $67 \mathrm{p}$.

Dini, Y.; Gere, J., Briano, C., Gratton, R. y Astigarraga, L. Efecto de la calidad de las pasturas sobre la emisión de metano en vacas lecheras en pastoreo. XXII Reunión Latinoamericana de Producción Animal (ALPA) 24 al 26 de octubre de 2011, Montevideo, Uruguay. Sección G (156). 
Enríquez, D. H., Ungerfeld, R., Quintans, G., Guidoni, A. L. y Hötzel, M. J. (2010). The effects of alternative weaning methods on behaviour in beef calves. Livestock Science 128(1-3), 20-27.

FAOSTAT. (2011). Food and Agricultural commodities production.

Giménez, A., Castaño, J. P., Olivera, L. y Baethgen, W. (2008). Cambio Climático en Uruguay y la Región. Documentos Online, 111, pp. 1-23. http://www.inia.org.uy/online/site/publicacion-ver.php?id=1698.

Gottardo, F., Ricci, R., Preciso, S., Ravarotto, L. y Cozzi, G. (2004). Effect of the manger space on welfare and meat quality of beef cattle. Livestock Production Science 89(2-3), 277-285.

Grandin, T. (2003). Transferring results of behavioral research to industry to improve animal welfare on the farm, ranch and the slaughter plant. Applied Animal Behaviour Science 81(3), 215-228

Grandin, T. (2008). Bienestar Animal: Actualización en especies productivas. II Seminario Internacional de Bienestar Animal : actualización en especies productivas. $15-8-2008$.

Graunke, K. L., Schuster, T. y Lidfors, L. M. (2011). Influence of weather on the behaviour of outdoor-wintered beef cattle in Scandinavia. Livestock Science 136(2-3), 247-255.

Halberg, N., van der Werf, H. M. G., Basset-Mens, C., Dalgaard, R. y de Boer, I. J. M. (2005). Environmental assessment tools for the evaluation and improvement of European livestock production systems. Livestock Production Science 96(1), 33-50. 
Hemsworth, P. H. (2003). Human-animal interactions in livestock production. Applied Animal Behaviour Science 81(3), 185-198.

Herrero, M., Gerber, P., Vellinga, T., Garnett, T., Leip, A., Opio, C., Westhoek, H. J., Thornton, P. K., Olesen, J., Hutchings, N., Montgomery, H., Soussana, J. F., Steinfeld, H. y McAllister, T. A. (2011). Livestock and greenhouse gas emissions: The importance of getting the numbers right. Animal Feed Science and Technology 166-167(0), 779-782.

Huber, R., Baumung, R., Wurzinger, M., Semambo, D., Mwai, O. y Winckler, C. (2008). Grazing, social and comfort behaviour of Ankole and crossbred (AnkoleáláHolstein) heifers on pasture in south western Uganda. Applied Animal Behaviour Science 112(3-4), 223-234.

Huertas, S. (2010). Actividades de investigación sobre el bienestar animal en la región de las Américas, iniciativas en curso y prioridades. Santiago, Chile, OIE. 1-7-2010.

Huertas, S. M., Gil, A. D., Piaggio, J. M. y van Eerdenburg, F. J. C. M. (2010). Transportation of beef cattle to slaughterhouses and how this relates to animal welfare and carcase bruising in an extensive production system. Animal Welfare 19(3), 281-285.

INAC. (2011). Faena, precios y exportación. Boletin semanal, Instituto Nacional de Carnes, pp. 1-17.

INAC (2009). Manual de Control de Calidad. http://www.inac.gub.uy/ innovaportal/v/4752/1/innova.net/manual_de_control_de_calidad. 40p.

INE (2011) Anuario estadístico 2010 del Instituto Nacional de Estadísticas. http://www.ine.gub.uy/biblioteca/anuario2010/anuario2010.swf 
INIA. (2011). Plan Estratégico Institucional 2011-2015.1ạ, INIA,. Montevideo, pp. $1-68$.

Irisarri, P.; Astigarraga, L.; Cardozo, E.; Del Pino, A.; Ferreira, M.; García, A.; Martino, D.; Methol, M.; Mieres, J.; Oyhantcabal, W.; Piaggio, L. y Trujillo, A. (2008). Estimation of uruguayan emission factors for $\mathrm{CH} 4$ from enteric fermentation and direct $\mathrm{N} 2 \mathrm{O}$ emissions from agricultural soils with grazing animals. In LEARN (Livestock Emissions \& Abatement Research Network) Workshop, 22-24 July 2008. Uruguay. http://www.congresosrohr.com/learn/paginasi/temas.html

Jaurena, M., Bentancur, O., Ayala, W. y Rivas, M. (2011). Especies indicadoras y estructura de praderas naturales de Basalto con cargas contrastantes de ovinos. Agrociencia.

Krupa, S. V. (2003). Effects of atmospheric ammonia (NH3) on terrestrial vegetation: a review. Environmental Pollution 124, 179-221.

La Manna, A. y Durán, H. (2008) Balance de nutrientes en tambos, una primera aproximación al proceso de intensificación y su potencial impacto en el ambiente. XXXVI Jornadas Uruguayas de Buiatría, 12, 13 y 14 de junio de 2008, Paysandú, Uruguay, 12-17.

Le Neindre, P. (2009) Some Perspectives of the Assessment of Farm Animal Welfare in the European Union. Agrociencia XIII (3), 28-34.

Lyons, C. A. P., Bruce, J. M., Fowler, V. R. y English, P. R. (1995). A comparison of productivity and welfare of growing pigs in four intensive systems. Livestock Production Science 43(3), 265-274. 
Marti M. (2010) Uruguay primero en consumo de carne per cápita. 180.com.uy 16/8/2010. http://www.180.com.uy/articulo/13357_Uruguay-primero-enconsumo-de-carne.

Martin, G. B. (2009) The 'Clean, Green and Ethical' Concept in Animal Production. Agrociencia XIII (3), 1-7.

Modernel P., Picasso V. y Astigarraga L. (2011) Emisiones de gases de efecto invernadero en tres sistemas de producción ganaderos de invernada de Uruguay. 3er Congreso Internacional y 12 - Congreso Nacional de InvestigaciónSocioeconómica y Ambiental de la Producción Pecuaria, "Producción Ganadera, Justicia Alimentaria y Cambio Climático" Morelia, Michoacán - 18, 19 y 20 de Mayo de 2011

Modernel, P., Picasso, V. y Astigarraga, I. (2010) Modeling GHG emissions of beef cattle production systems in Uruguay. In Proccedings of the Greenhouse Gases and Animal Agriculture Conference, 3-8 october, Banff, Canada, http://www.ggaa2010.org./abstracts.shtml

Montossi, F. y del Campo, M. (2007) Sistemas de Producción: Oportunidades y Desafíos para el Bienestar Animal en Uruguay. Congreso de Bienestar Animal Nuevos Horizontes para el siglo XXI - Una perspectiva internacional y regional. Montevideo, http://www.inia.org.uy/publicaciones/documentos /semcon/07_bi_ani/ba_20.pdf.

Mormede, P., Andanson, S., Auperin, B., Beerda, B., Guémené, D., Malmkvist, J., Manteca, X., Manteuffel, G., Prunet, P., van Reenen, C. G., Richard, S. Y Veissier, I. (2007) Exploration of the hypothalamic-pituitary-adrenal function as a tool to evaluate animal welfare. Physiology \& Behaviour 92(3), 317-339. 
Muzio, F. (2007). El bienestar Animal en el Uruguay. Congreso Internaciobal de Bienestar Animal. Montevideo, INIA. 24-4-2007.

Nabinger, C.; Carvalho, P.; Pinto, E.; Mezzalira, J.; Martins, D.; Boggiano, P. Servicios ecosistémicos de las praderas naturales: ¿es posible mejorarlos con más productividad? XXII Reunión ALPA, Montevideo, Uruguay. 24-26 octubre de 2011. Sección Pasturas. pp 2-14.

Nozar, G. (2007). Evaluación del impacto, económico, social y ambiental de la investigación del INIA en arroz y lechería (período 1990-2005). IICA, INIA, and Procisur. INIA, pp. 1-27. Montevideo.

UN Comtrade (2011) The 2010 International Trade Statistics Yearbook, Volume I Trade by Country. http://comtrade.un.org/

OPYPA (2010) Anuario 2010 OPYPA. MGAP, Montevideo, 446p. http://www.mgap.gub.uy/portal/hgxpp001.aspx?7,7,462,0,S,0,MNU;E;66;7;M $\mathrm{NU}$

OPYPA (2009) Anuario 2009 OPYPA. MGAP, Montevideo, 480p. http://www.mgap.gub.uy/opypa/ANUARIOS/Anuario2009/material/htm/indic e.htm

Oyhantcabal, G. (2010). Cambio climático y biodiversidad. Seminario de conservación y uso sostenible de la biodiversidad, [1]. PPR-MGAP.

Paranhos da Costa, M. (2011). O comportamento como indicador de bem-estar animal. II Congresso Regional de Etología Aplicada, 1[1]. Ilheus, Brasil, ISAE. 234-2011. 
Petherick, J. C. (2005). Animal welfare issues associated with extensive livestock production: The northern Australian beef cattle industry. Applied Animal Behaviour Science 92(3), 211-234.

Petherick, J. C. y Phillips, C. J. C. (2009). Space allowances for confined livestock and their determination from allometric principles. Applied Animal Behaviour Science 117(1-2), 1-12.

Poder Legislativo ROU. (2009) Diario Oficial 16 enero de 2007- № 27161,

Montevideo.

Poder Legislativo ROU. (2009). Ley 18.471, Normas relacionadas con el Bienestar animal. Diario Oficial 21 de abril de 2009, pp. 175A-178A. Montevideo.

PPR-MGAP (2008) Manual para el manejo de efluentes de tambo. 1a ed. 127p. Ministerio de Ganadería Agricultura y Pesca, Montevideo.

Presidencia de la República oriental del Uruguay. (2010). INAC presentó cifras de exportación y faena que demuestran crecimiento del sector cárnico. http://www.presidencia.gub.uy/sci/noticias/2010/12/2010121508.htm. 15-42011.

Presidencia de la República oriental del Uruguay. (2011). Ejecutivo aprueba proyecto de ley que grava concentración de la tierra. http://www.presidencia.gub.uy/wps/wcm/connect/presidencia/portalpreside ncia/comunicacion/comunicacionnoticias/impuesto-agro-ministros

Roney, N., Llados, F., Little, S. S. y Knaebel, D. B. (2004). Toxicological Profile of Ammonia., U.S. Department of Health and Human Services, pp. 1-269. 
Rovira, P. y Velazco, J. (2010). The effect of artificial or natural shade on respiration rate, behaviour and performance of grazing steers. New Zealand Journal of Agricultural Research 53(4), 347-353.

Rovira, P. J. y Velazco, J. I. (2011). Performance and behavior of steers on natural pastures with proteic supplementation and artificial shade during summer. Revista Veterinaria 22(1), 32-37.

Safley, L. M. Jr., Casada, M. E., Woodbury, J. W. y Roos, K. F. (1992). Global methane emission from livestock and poultry manure.1, U.S.Environmental Protection Agency,Air and Radiation,. Washington D.C., pp. 1-145.

Sawchik, J. (2010). La Intensificación Agrícola y las oportunidades de la Ganadería: Una Mirada desde los Recursos Naturales. 60 Congreso del Campo al Plato. http://www.delcampoalplato.org/congreso2010.htm, INAC, INIA, MGAP.

Schütz, Rogers, A. R., Poulouin, Y. A., Cox, N. R. y Tucker, C. B. (2010). The amount of shade influences the behavior and physiology of dairy cattle. Journal of Dairy Science 93(1), 125-133.

SJR (2012) SCImago Journal and Country Rank. http://www.scimagojr.com/ compare.php

SNRCC (2011) Unidad de Cambio Climático. Sistema Nacional de Respuesta al Cambio Climático. http://www.cambioclimatico.gub.uy/

Steinfeld, H., Gerber, P., Wassenaar, T., Castel, V., Rosales, M. y de Haan, C. (2006). Livestock's long shadow. FAO, pp. 1-377.

Stukenborg, A., Traulsen, I., Puppe, B., Presuhn, U. y Krieter, J. (2011). Agonistic behaviour after mixing in pigs under commercial farm conditions. Applied Animal Behaviour Science 129(1), 28-35. 
Temple, D., Manteca, X., Velarde, A. y Dalmau, A. (2011). Assessment of animal welfare through behavioural parameters in lberian pigs in intensive and extensive conditions. Applied Animal Behaviour Science In Press, Corrected Proof.

Tieri, M. P., La Manna, A., Montossi, F., Banchero, G., Mieres, J. y Fernández, E. (2011). El balance de nutrientes en 36 predios comerciales del GIPROCAR II (FUCREA/INIA): una primera aproximación al proceso de intensificación en sistemas agrícola-ganaderos y su potencial impacto en el ambiente. Jornada de Ganadería "El menú de la invernada". INIA Serie Actividades de Difusión, INIA, 658, pp. 16-22.

Tucker, C. B., Rogers, A. R. y Schütz (2008). Effect of solar radiation on dairy cattle behaviour, use of shade and body temperature in a pasture-based system. Applied Animal Behaviour Science 109(2-4), 141-154.

Ungerfeld, R., Hötzel, M. J., Scarsi, A. y Quintans, G. (2011). Behavioral and physiological changes in early-weaned multiparous and primiparous beef cows. Animal 5(8), 1270-1275.

van de Weerd, H. A. y Day, J. E. L. (2009). A review of environmental enrichment for pigs housed in intensive housing systems. Applied Animal Behaviour Science 116(1), 1-20.

Viñas, M. y Gutiérrez, S. (2008). Estimación de los parámetros nacionales y básicos para el procesamiento y utilización de residuos sólidos y líquidos de tambos. FPTA, INIA, 138. La Estanzuela.

Welfare Quality ${ }^{\circledR}$. (2009). Principios y criterios para el Bienestar de los Animales de Granja. WQ-Factsheet-10-07-sp, pp. 1-2. http://www.welferquality.net/ 
downloadattachment/41858/19877/WQ\%20_\%20Factsheet_10_07_sp\%20(2). pdf.

Witt, G. B., Nodl, M. V., Bird, M. I., Beeton, R. J. S. y Menzies, N. W. (2011). Carbon sequestration and biodiversity restoration potential of semi-arid mulga lands of Australia interpreted from long-term grazing exclosures. Agriculture, Ecosystems \& Environment 141(1-2), 108-118.

Zarza, R. (2010). Carnes: escenario de cambios. Alimentos Argentinos 49, Secretaría de Agricultura Ganadería y Pesca de la Nación Argentina, pp. 15-21. Buenos Aires.

Zunckel, M., Saizar, C. y Zarauz, J. (2003). Rainwater composition in northeast Uruguay. Atmospheric environment 37(12), 1601-1611. 
Capítulo 2

Behavioral characterization of three Holstein

steers production systems 



\section{Abstract}

Beef production in Uruguay is mainly based on grazing systems. However, in the last years, intensive production systems have been developed, with possible effects on animal behaviour. The present study's objective is to characterize the behaviour of three different Holstein steers production systems. 48 Holstein castrated males were randomly divided into three groups, corresponding to three treatments: (T1) confined into a 210 square meters yard, (T2) confined into a similar yard with six hours of access to grassland, (T3) permanently placed at grassland. Behaviour was registered by scan sampling, during twelve hours a day (from 7:00 to 19:00), three days per week, in four weeks distributed throughout the experiment. In order to describe behaviour patterns, a negative binomial regression, correspondence analysis and logistic regressions were performed.

Grazing was the main behaviour in $\mathrm{T} 2$ and $\mathrm{T} 3$, while eating hay was the most frequent in T1. For all treatments, lying was the second more frequent behaviour. Despite animals in T2 accessed to grassland only half of the time than those in T3, grazing behaviour was not produced in the same proportion, as the difference between them is only $6.5 \%$. Correspondence analysis (CA) showed that dimension 1 explained $93.1 \%$ of the variation, and separates T1 from T2 and T3. For the the study of weather conditions throughout a CA, several behaviours resulted to be close to certain conditions. E.g. standing and "ruminating while standing" are closer to light rainy weather, whereas "lying" or "ruminating while lying" are more related to sunny weather. Logistic regression, showed that lying tend to increase along the day in all treatments, while "eating hay" increased in T1 but decreased in T2 and T3. It is concluded that the management conditions associated to the studied systems produced different behavioural patterns of steers. Nutritional related behaviour occupied most of the time in all the systems. Grazing behaviour 
is important for the animals and the permanent or restricted possibility to perform it (determined by the production system itself), changes the patterns of other behaviours in order to give priority to pasture intake. 


\section{Introduction}

Beef production in Uruguay is turning into more intensive systems. Cattle stock has increased from 11.3 in 2002 to 11.7 million heads in 2009, while the area used to this aim has been reduced from 14.6 to 12.3 million hectares (DIEA, 2010). This fact is due to the raise in the land cost and the need of increasing the productivity for competition with cereals production (Simeone and Berreta, 2007).

In the dairy production region of the country, Holstein male calves and steers were traditionally destined to meat production in pure grazing systems, but recently, feedlot systems have been developed in this region (Ruggia et al., 2011). These new management systems modify animal conditions, by reducing their space allowance, changing feeding and resting conditions, and influencing social behavior (Kondo et al., 1989), with a possible effect on welfare and productivity.

On the other hand, consumers are becoming increasingly concerned about the care and management of the livestock, and these concerns with an important role in purchasing behavior (Verbeke and Viaene, 1999; Verbeke et al., 2010).

Different production systems may cause alteration in behavior patterns of calves or steers, which could affect their welfare. One of the most common aspects of these systems, reported as influencing behavior, is housing (Bokkers and Koene, 2001b; Andrighetto et al., 1999; Bak Jensen et al., 1997; Hepola et al., 2006), but also diet (Phillips, 2004; Morisse et al., 2000; van Ackeren et al., 2009), group size (Hepola et al., 2006; Babu et al., 2004) and handling (Gupta et al., 2008; Mohan Raj et al., 1991).

Animal behavior is regarded as one of the best indicators of animal welfare (Broom and Johnson, 1993). Behavior is the tool used by animals for adapting and 
controlling the environment, therefore it is very useful to obtain information of their needs, preferences and internal states (Mench and Mason, 2005). Some scientists have adopted a natural-living approach, proposing that animal's welfare depends on its being allowed to perform its natural behavior (Fraser et al., 1997). In this approach, grazing beef production systems, seem to be more respectful with natural behavior than intensive systems. If compared to intensively-reared animals, cattle reared under extensive conditions seem not to have behavioral restrictions. However, the 'natural' conditions associated with extensive livestock production could create a substantial number of welfare problems, like nutrition, human-animal relationship, sanitary problems, mustering, restraint and handling, etc. (Petherick, 2005).

Abnormal behaviors are used as poor welfare or distress indicators. This type of behaviors often result when animals are exposed to chronic aversive stimuli (Garner, 2005). Stricklin and Kautz-Scanavy (1984) reviewing the role of behavior in cattle production, affirm that management systems should be designed to match more closely the behavioral "needs" of cattle, which could increase efficiency of production and guide research into more beneficial directions.

In this context, the main objective of the present work, is to describe and to characterize the behavior, its relationship with environment conditions and possible effect on welfare, of young Holstein steers reared in three different production systems. These systems represent the traditional one, the new developed confined systems and an intermediate option that combine confined and grazing periods. 


\section{Materials and methods}

The experiment was carried out at Las Brujas Experimental Centre of the National Agricultural Research Institute (INIA) of Uruguay (3440'S lat, 5620' W, 36 m alt). The experimental period lasted 133 days, from August 4 to December 16 of 2008.

\subsection{Animals and housing}

Experimental design was established according to Manninen et al. (2007). Forty eight Holstein castrated males (mean live weight at start $93 \pm 20.3 \mathrm{~kg}$ ), were randomly divided into three groups (16 calves each) corresponding to three treatments:

(T1) confined into a 210 square meters yard,

(T2) confined into a 210 square meters yard with six hours of access to grassland,

(T3) permanent placed at grassland.

All animals were individually identified in the ear (number id) and in each group different colour collars were used for each animal, for helping individualizing in behavior studies. All experimental measurements started on September 15, after an adaptation period of 43 days.

The experimental yards (treatments T1 and T2) consisted on an outdoor $21 \times 10 \mathrm{~m}$ yard, built with electric fencing. The grassland parcels were also built with electric fencing, and the surface was calculated depending on the forage offered to reach $8 \%$ of average live weight per animal. Average surface was about 2000 square meters. 
Animals assigned to $\mathrm{T} 1$ were permanent placed in the yard with automatic water trough and fed ad libitum with alfalfa hay. Twice a day at 9:00 and 16:00, sorghum humid grain silage ( $2 \%$ of average live weight) and sunflower and soybean expeller, was supplied. Animals assigned to T2 were placed in the yard with an automatic water trough, fed ad libitum with alfalfa hay and sorghum humid grain silage (1.5\% of average live weight) supplied in a unique moment at 16:00. In addition, they were moved six hours per day (10:00 to 16:00) to a grassland parcel with an additional water trough. Calves in T3 were permanently in grassland, with free availability of alfalfa hay and water. Pasture offered was a mix of alfalfa, red clover and ryegrass.

\subsection{Behavioral observations}

The calves' behavior was directly observed, twelve hours a day, three days per week in four weeks distributed throughout the experiment (weeks 7, 10, 13 and 16). Six people were trained to perform the behavioral observations, and then, there was one observer for each treatment, in three hours turns. Observers were randomly assigned to each treatment and timetable every day. Behavioral observations were carried out by scan sampling every five minutes according to the ethogram presented in Table 1.

To evaluate the possible effects on behavior, climate condition was qualified in each behavioral observation as cold, warm or hot and the weather qualified as sunny, cloudy and light rainy. 
Table 1. Observed behaviors and its respective descriptions (partially adapted from (Hepola et al., 2006)

\begin{tabular}{|c|c|}
\hline Behavior & Description \\
\hline Eating hay $(\mathrm{EH})$ & Calf having hay in its mouth or head in the hay trough \\
\hline Eating grain (EG) & $\begin{array}{l}\text { Calf having concentrate in its mouth or head in the } \\
\text { concentrate trough }\end{array}$ \\
\hline Drinking (D) & Calf having it head in the water trough \\
\hline Grassing (G) & Calf having grass in its mouth or head in the grassland \\
\hline Walking (W) & Calf walking without a clear direction or objective \\
\hline Moving to water (MW) & Calf walking clearly directed to water throw \\
\hline Moving to grassland (MG) & Calf walking clearly directed to water throw \\
\hline Standing (S) & Calf standing without any other distinguished activity \\
\hline Lying (L) & Calf lying without any other distinguished activity \\
\hline Ruminating while standing (SR) & $\begin{array}{l}\text { Repetitive movements of lower jaw in the lateral plane, } \\
\text { while standing }\end{array}$ \\
\hline Ruminating while lying (LR) & $\begin{array}{l}\text { Repetitive movements of lower jaw in the lateral plane, } \\
\text { while lying. }\end{array}$ \\
\hline Licking themselves (LT) & Calf licking any part of itself \\
\hline Licking object (LO), & Calf's tongue touching any part of the structure or object \\
\hline Interaction with other animal (I) & $\begin{array}{l}\text { Calf with a behavior directed to another calf mounting } \\
(\mathrm{M}) \text {, displacing (Di), charging (Ch), licking another } \\
\text { animal (Lo) and smelling (Sm). }\end{array}$ \\
\hline Total eating behavior $(\mathrm{E})$ & $\begin{array}{l}\text { Integration of grazing (G), eating hay (EH) and eating } \\
\text { grains (EG) }\end{array}$ \\
\hline Other $(\mathrm{O})$ & Other no described behavior \\
\hline
\end{tabular}




\subsection{Statistical analysis}

In order to describe the general pattern of each behavior in the observation period, a negative binomial regression was applied using SAS GENMOD procedure (SAS Institute Inc, 2008). The model included treatment (T1, T2 and T3), date, week of observation (7, 10,13 and 16) and observer as fixed effects. The least square means of treatment (LSMEANS) with Tukey adjustment was used and accepted significance level was fixed at $P<0.05$. In addition, to compare T1 and T2, two periods were defined: one between 10:00 and 16:00, when animals in T1 and T2 had access to the grassland, was called period IN; the time in which animals under T2 were not in the grassland was called period OUT (7:00 to 10:00 and $16: 00$ to $19: 00)$.

Complementary, it was examined whether or not the probability of a certain behavior being produced was influenced by the time of the day in each system. It was done through a logistic regression with repeated measures in the SAS GENMOD procedure (SAS Institute Inc, 2008). Logistic regression is expressed in terms of the logistic regression coefficient $\left(B_{0}\right)$ and the odds ratio, which shows the strength of association between a predictor and the response of interest and can vary from 0 to infinit). In addition, a logistic regression was also applied in order to find general differences between the three systems, regardless the time of the day.

Finally, all behavioral data were subjected to a correspondence analysis in order to find a low-dimensional graphical representation. It was performed throughout procedure CORRESP (SAS Institute Inc, 2008). With this analysis, the similarity between each treatment and each behavior can be obtained. In addition, correspondence analysis was also performed in order to identify any possible associations between climatic conditions and behavioral aspects. 


\section{Results}

\subsection{Behavior frequency.}

Behavior of steers in the different systems showed differences in time destined to each conduct, not only in those exclusive of some systems like grazing or eating grain, but also in common behaviors. Behavioral patterns, represented as the proportion of animals doing specific activities in the 12-h observation period are presented in Table 2. This representation must be understood as an average proportion of time utilization along the studied period.

Table 2 - Proportion (\%) of animal doing the main behaviors (EH: eating hay, EG: eating grain, L: lying, LR: ruminant while lying, SR: ruminant while standing, S: standing, D: drinking, W: walking and E: total eating,) for the total period observed in T1, T2 and T3 treatments.

\begin{tabular}{lllllll}
\hline \multirow{2}{*}{ Behavior } & T1 & \multicolumn{3}{l}{ T2 } & \multicolumn{2}{l}{ T3 } \\
\cline { 2 - 7 } & range & mean & range & mean & range & mean \\
\hline G & -- & -- & $19.05-35.41$ & $31.3^{\mathrm{b}}$ & $30.07-57.61$ & $37.8^{\mathrm{a}}$ \\
EH & $31.47-55.03$ & $35.0^{\mathrm{a}}$ & $7.15-12.36$ & $12.0^{\mathrm{b}}$ & $5.21-9.24$ & $6.9^{\mathrm{b}}$ \\
EG & $2.63-10.85$ & $5.8^{\mathrm{a}}$ & $1.66-7.05$ & $4.3^{\mathrm{a}}$ & -- & -- \\
LR & $10.31-15.72$ & $12.3^{\mathrm{a}}$ & $8.63-13.04$ & $11.2^{\mathrm{a}}$ & $11.37-17.29$ & $15.4^{\mathrm{a}}$ \\
SR & $2.68-4.20$ & $3.5^{\mathrm{b}}$ & $1.29-2.10$ & $1.9^{\mathrm{a}}$ & $1.59-2.57$ & $2.0^{\mathrm{a}}$ \\
$\mathrm{S}$ & $11.87-16.41$ & $14.5^{\mathrm{a}}$ & $9.30-13.03$ & $11.9^{\mathrm{b}}$ & $6.81-9.58$ & $8.3^{\mathrm{c}}$ \\
$\mathrm{L}$ & $16.58-24.84$ & $21.4^{\mathrm{a}}$ & $15.36-22.93$ & $18.9^{\mathrm{a}}$ & $14.42-21.81$ & $18.4^{\mathrm{a}}$ \\
$\mathrm{D}$ & $1.58-2.25$ & $1.9^{\mathrm{a}}$ & $0.85-1.20$ & $1.1^{\mathrm{b}}$ & $1.08-1.61$ & $1.3^{\mathrm{b}}$ \\
W & $0.57-0.96$ & $0.7^{\mathrm{b}}$ & $1.72-2.62$ & $2.1^{\mathrm{a}}$ & $1.43-2.23$ & $1.8^{\mathrm{a}}$ \\
E & $38.3-48.5$ & $43.1^{\mathrm{b}}$ & $35.6-45.3$ & $40.2^{\mathrm{ab}}$ & $43.2-75.0$ & $48.7^{\mathrm{a}}$ \\
\hline abc Means followed of similar letters in the row don't differ significant $(\mathrm{p}<0.05)$
\end{tabular}


Except for T1, where animals were confined permanently without access to grassland, grazing was the most important activity in $\mathrm{T} 2$ and $\mathrm{T} 3$, considering the proportion of the total time used. Conversely, the most frequent behavior in T1 was eating hay, and lying (L) was the second behavior in time use importance in all treatments and did not differ between treatments. The frequency of observations of ruminating while lying (LR) did not differ within treatments, but T2 showed a higher proportion of animal doing ruminant while standing (SR).

On the other hand, animals in T1 spent more time standing (S) and drinking (D) and less time walking (W) than the other treatments.

Table 3 - Proportion (\%) of animal doing G: Grazing, LR: ruminant while lying, SR: ruminant while standing, for the periods "IN" (10:00 to 16:00) and "OUT" (7:00 to 10:00 and 16:00 to 19:00) in treatments T2 and T3.

\begin{tabular}{llllllc}
\hline Behavior & & \multicolumn{2}{l}{ T2 } & & T3 & $\mathrm{p}$ \\
\hline \multirow{2}{*}{$\mathrm{G}$} & & Range & Mean & Range & Mean & \\
\cline { 3 - 7 } & IN & $48.78-81-23$ & 62.9 & $20.92-35.17$ & 27.1 & $<0.0001$ \\
& OUT & -- & -- & $36.42-60.52$ & 46.9 & \\
\hline $\mathrm{p}$ & & & & & 0.0036 & \\
\hline \multirow{2}{*}{$\mathrm{LR}$} & IN & $4.58-9.05$ & 6.4 & $11.88-22.37$ & 16.3 & $<0.0001$ \\
& OUT & $10.33-19.71$ & 14.3 & $7.98-15.13$ & 11.0 & NS \\
\hline $\mathrm{p}$ & & & 0.0015 & & $\mathrm{NS}$ & \\
\hline \multirow{2}{*}{$\mathrm{SR}$} & IN & $0.44-1.00$ & 0.7 & $1.32-2.54$ & 1.8 & 0.0002 \\
& OUT & $1.99-3.93$ & 2.8 & $1.40-2.77$ & 2.0 & $\mathrm{NS}$ \\
\hline $\mathrm{p}$ & & & $<0.0001$ & & $\mathrm{NS}$ &
\end{tabular}

Regarding grazing (G), although animals in $\mathrm{T} 2$ accessed to the grassland only half of the time than those in $T 3$, the reduction in this behavior frequency is not 
produced in the same proportion, as the difference between both means is only $6.5 \%$. As regards to this behavior, it can be observed in Table 3 that during period "IN" (10:00 to $16: 00)$ in T2, $62.9 \%$ of the animals were grazing. This represents more than twice the frequency registered in T3 for this period that was $27.1 \%$.

If behavior is analyzed in relation to the possibility or not of access to grassland, $T 2$ reduced $L R$ in the period IN whereas no differences between both treatments were observed for period OUT as it is showed in Table 3.

Considering both periods for each treatment, no differences were found for both LR and SR in T3. In the case of T2, both behaviors (LR and TR) were more frequent in the OUT period.

The time destined to total eating behaviors (E) was higher for T3 than for T1, while 12 did not differ from the other treatments as can be seen in Table 2 .

The influence of IN and OUT periods on E behavior in T2 and T3 are presented in Table 4.

Table 4 - Proportion (\%) of animal doing Eating behaviors (grazing: G + eating hay: EH+ eating grains: EG) for the total observation period and for the periods "IN" (10:00 to 16:00) and "OUT" (7:00 to 10:00 and 16:00 to 19:00) in T2 and T3 treatments.

\begin{tabular}{|c|c|c|c|c|c|}
\hline \multirow{2}{*}{ Period } & \multicolumn{2}{|l|}{ T2 } & \multicolumn{3}{|l|}{ T3 } \\
\hline & Range & Mean & Range & Mean & $p$ \\
\hline IN & $52.28-76.49$ & 63.2 & $34.89-51.34$ & 42.4 & 0.0051 \\
\hline OUT & $24.22-35.75$ & 29.4 & $45.94-67.34$ & 55.9 & $<0.0001$ \\
\hline$p$ & & $<0.0001$ & & NS & \\
\hline
\end{tabular}


Considering the period IN, T2 presented a higher proportion of animals eating than T3. Nevertheless, while in T3 the frequency of E behavior in period OUT was not different from period IN, T2 reduced $\mathrm{E}$ behavior for this period.

\subsection{Logistic regression. Daily patterns}

Logistic regression analysis showed in one hand, differences between the three treatments for each behavior, and on the other hand, different relationships between the time of the day and the studied behaviors in the treatments. This analysis was carried out for each behavior except for EG, as grain was supplied only twice a day and it was mainly consumed at that moment.

In Table 5, the statistics of the models are shown.

As it is seen in the Table 5, no differences could be found between systems for $D$ behavior, although a daily pattern in $\mathrm{T} 1$ is present as the significance level of the time of the day shows.

However, there are other behaviors (SR, $\mathrm{L}$ or $\mathrm{EH}$ ) that are different in general terms only in $\mathrm{T} 1$ respect to $\mathrm{T} 2$ and $\mathrm{T} 3$, although present statistically significant differences and according to their intercept values, animal in T1 are more likely to perform those behaviors than animals in $\mathrm{T} 2$ and $\mathrm{T} 3$.

Regarding the influence of the time of the day and the daily pattern of each studied behavior, Figure 1 shows a graph of the calculated logistic equations for main activities during the observation period. This graph plots the expectable proportion of animals doing a specific activity in a specific moment of the day between 7:00 and 19:00.

As it can be observed, total eating behavior had different patterns in the three systems. In T1 it increases during the day according to EH positive intercepts. 
Moreover, in T3, hay consumption along the day is decreased while the intake of grassland increases. In the case of $\mathrm{T} 2, \mathrm{EH}$ and $\mathrm{G}$ also decrease during the day. Related to this, drinking behavior had a stable pattern along the day for T2 and T3 ( $P=0.5363$ and $P=0.5474$, respectively), while in $T 1$ the probability is increased along the day $(ß=0.785$, Odds $=2.192)$.

As regards to pure activity or inactivity behaviors, L presented an increasing tendency along the day for all treatments and in opposite to this, standing tended to decrease (negative intercepts in the three treatments). On the contrary, walking behavior was different in probability of occurrence for each moment in the three treatments. It showed a decreasing pattern in $\mathrm{T} 1$ ( $\beta=-13.337$, Odds $=0.000$ ), while in $T 2$ it was increased during the day ( $\beta=0.685$, Odds $=1.984$ ) and T3 had a stable pattern $(P=0.3036)$. 
Table 5. Logistic regression statistics for the differences between treatments and the influence of the time of the day in each treatment

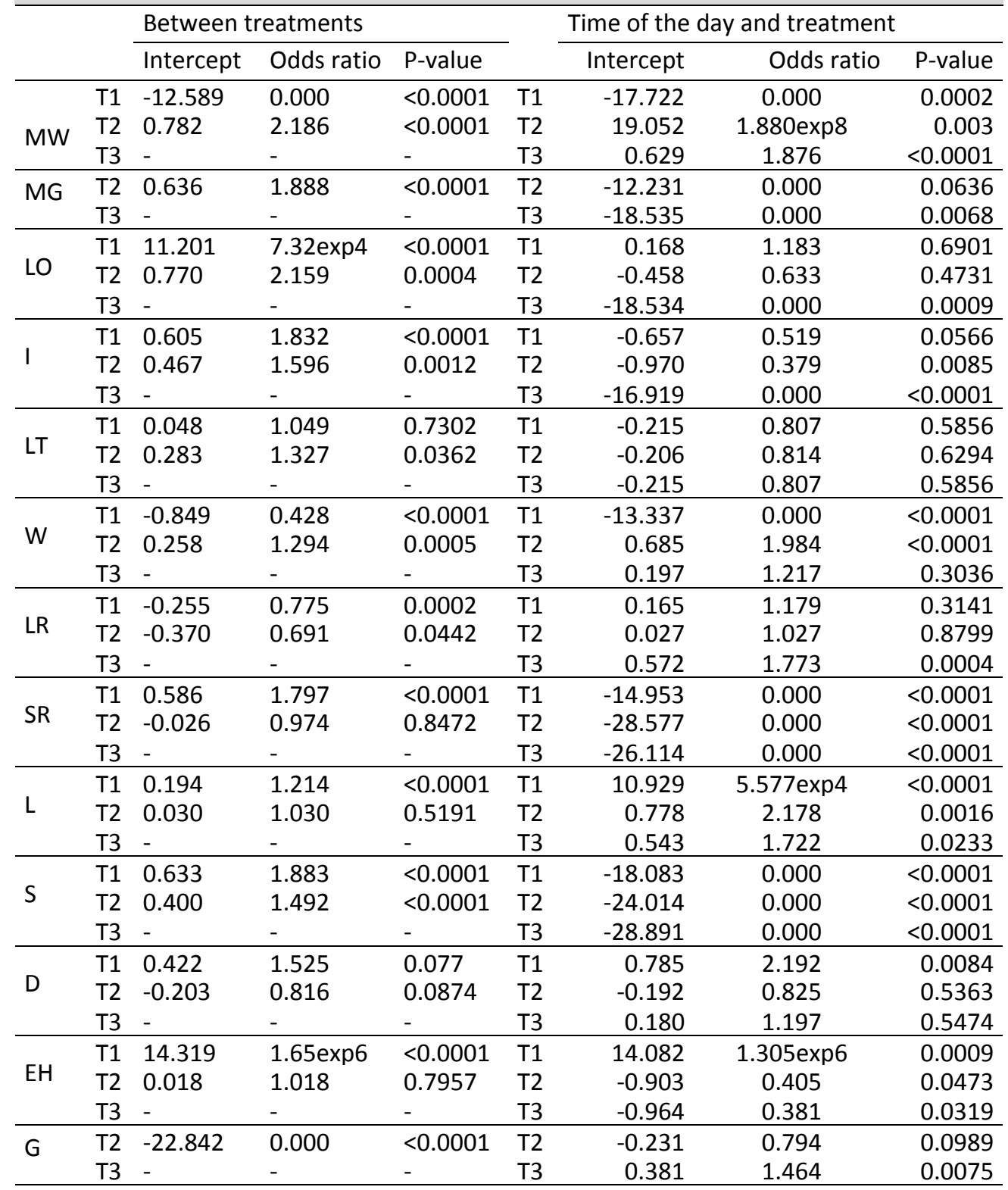


Regarding specific behaviors such as ruminating while lying, this was stable during the day for $\mathrm{T} 1$ and $\mathrm{T} 2$ ( $\mathrm{P}=0.3141$ and $\mathrm{P}=0.8799$, respectively), but in $\mathrm{T} 3$,

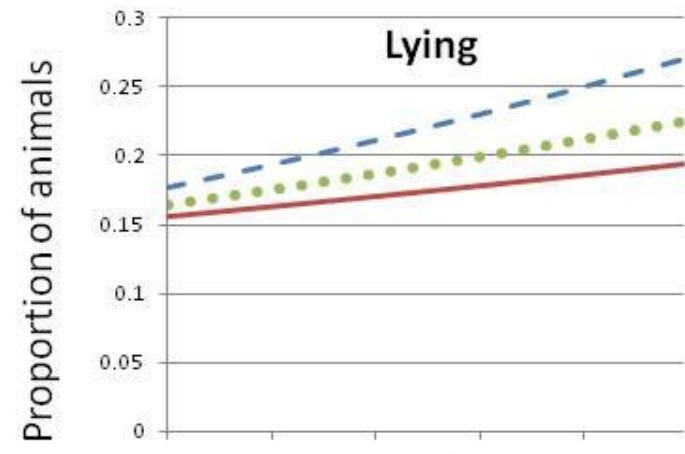

07:00:00 09:24:00 11:48:00 14:12:00 16:36:00

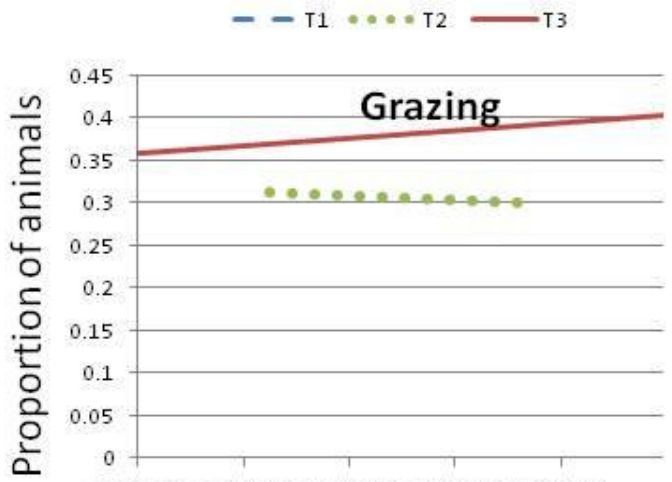

07:00:00 09:24:00 11:48:00 14:12:00 16:36:00

$\cdots \mathrm{T} 2 \longrightarrow \mathrm{T} 3$

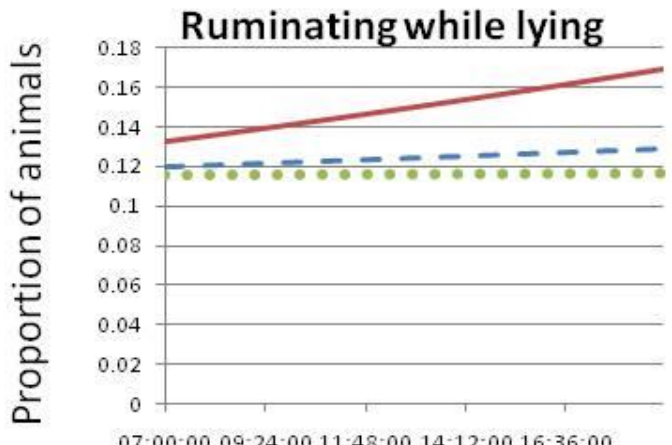

07:00:00 09:24:00 11:48:00 14:12:00 16:36:00

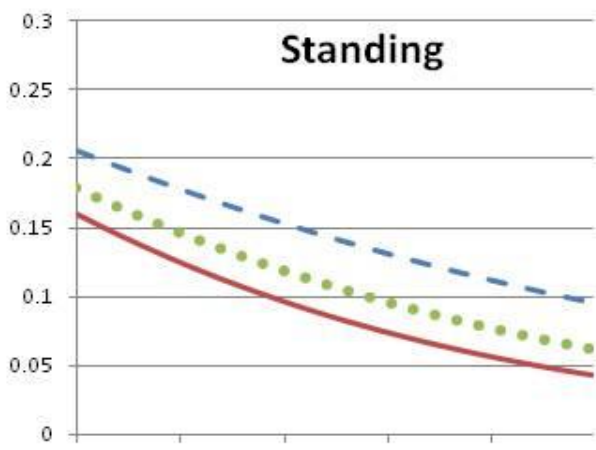

07:00:00 09:24:00 11:48:00 14:12:00 16:36:00
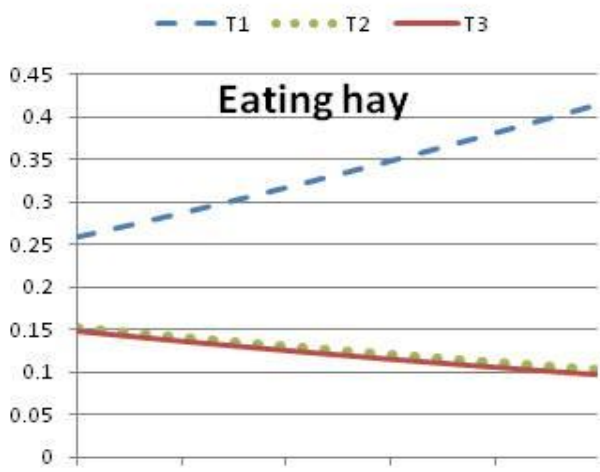

07:00:00 09:24:00 11:48:00 14:12:00 16:36:00

$--\mathrm{T}_{1} \cdots \mathrm{T}_{2}-\mathrm{T} 3$

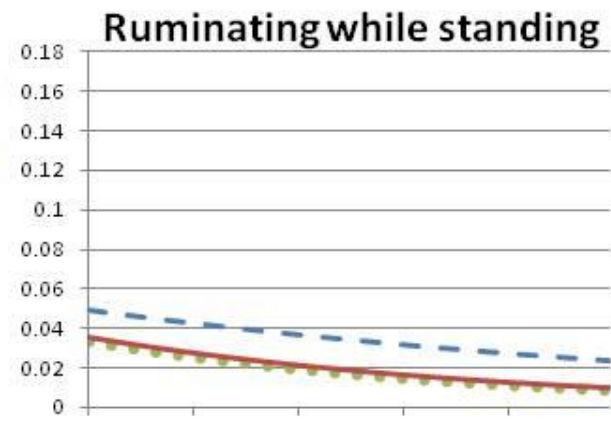

07:00:00 09:24:00 11:48:00 14:12:00 16:36:00 
Figure 1 - Graphs of the calculated logistic equations for main activities in the observation period.

it showed an increasing tendency along the day ( $\beta=0.572$, Odds=1.773). In addition, according to logistic regression between treatments, this behavior is mainly performed in $\mathrm{T} 3$, as the animals in $\mathrm{T} 1(\beta=-0.255$, Odds $=0.775, \mathrm{P}=0.0002)$ and T2 ( $B=-0.370$, Odds $=0.691, P=0.0442)$ are less likely to perform it as compared to T3.

In contrast to this, ruminating while standing showed similar descendent tendencies for all treatments, but in T1 there is a higher probability of finding animals performing this behavior during the observation period ( $\beta=0.586$, Odds=1.797).

\subsection{Correspondence analysis}

Table 6 shows the similarity values for all behaviors in each treatment (from T1 to T3).

According to the inertia values presented in Figure $2,93.20 \%$ of the chi squared for association between values is accounted by the first dimension. In fact, dimension 1 in this plot separates the three treatments. This dimension indicates a difference between behavioral profiles of $\mathrm{T} 1$ and the other treatments. The second dimension is more related to the specific behaviors (mainly EG, LR and $M W)$, according to their partial contribution to the inertia.

This pattern shown in the plot and in Table 5, indicates that behaviors and treatments are differently related in this work. As it is seen, animals are more likely to eat hay $(\mathrm{EH})$ more frequently in $\mathrm{T} 1$, while walking is closer to $\mathrm{T} 2$.

In addition, certain behaviors such as L, I, LO, S or SR are more related to T1, while G, LR or LT are more likely to be produced under T2 and T3. 


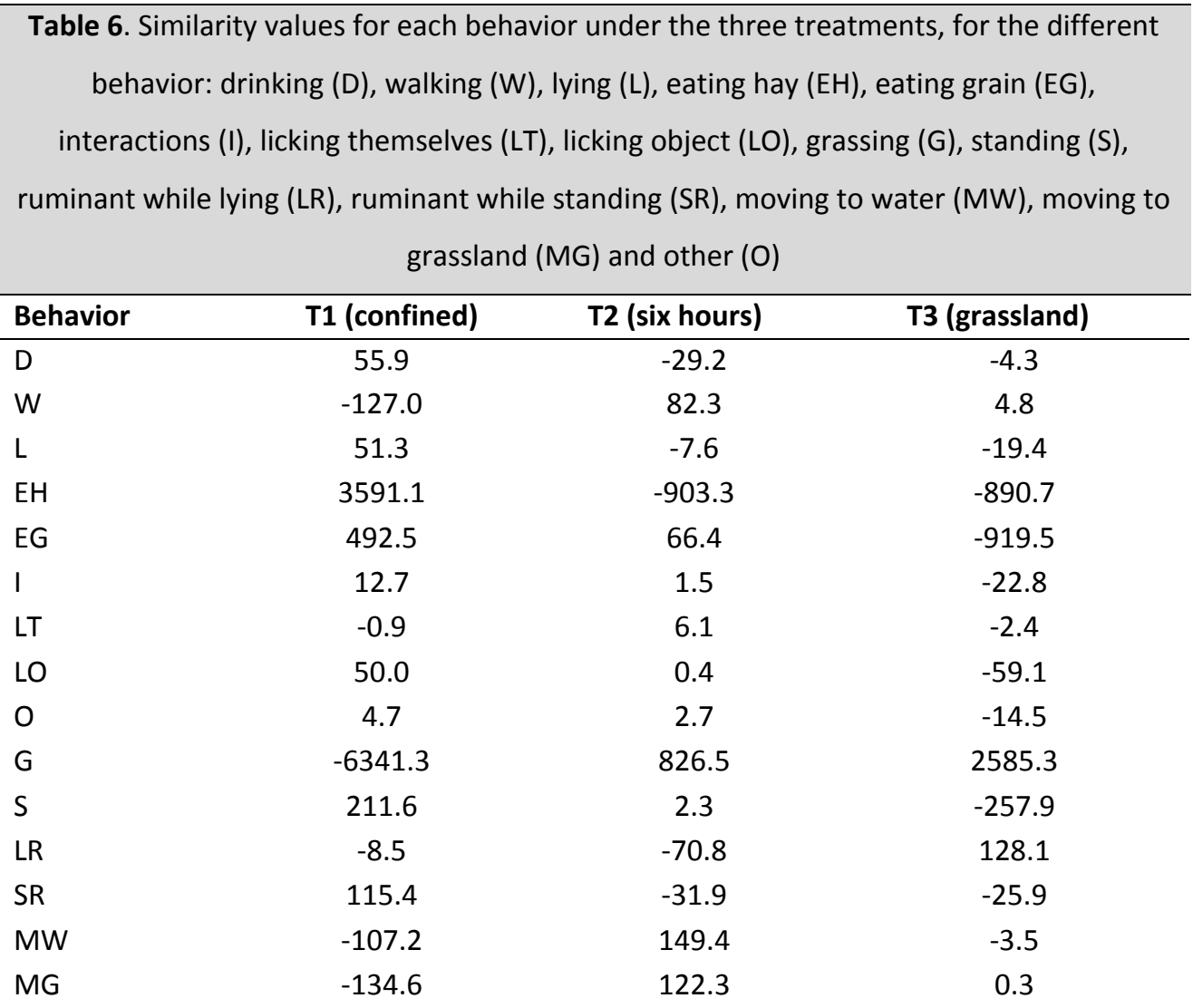

In Table 7 and Figures 2, 3 and 4, results of the correspondence analysis for weather conditions are shown. 


\begin{tabular}{|c|c|c|c|c|c|c|c|c|c|}
\hline & \multicolumn{3}{|c|}{ T1 } & \multicolumn{3}{|c|}{$\mathrm{T2}$} & \multicolumn{3}{|l|}{ T3 } \\
\hline & Cloudy & Rainy & Sunny & Cloudy & Rainy & Sunny & Cloudy & Rainy & Sunny \\
\hline D & -1.22 & 1.15 & 0.16 & -0.951 & -15.78 & 4.649 & 18.31 & -6.89 & -4.46 \\
\hline w & -2.27 & 4.61 & 0.09 & -11.148 & -47.85 & 24.347 & -0.57 & 0.00 & 0.29 \\
\hline L & -17.43 & -265.2 & 80.00 & 26.367 & -32.71 & -2.555 & -14.19 & -72.52 & 34.09 \\
\hline $\mathrm{EH}$ & 103.37 & 13.64 & -74.99 & 0.145 & -3.467 & 0.167 & 122.22 & 682.40 & -308.0 \\
\hline EG & -83.16 & 29.61 & 20.91 & -25.350 & -94.69 & 51.616 & -- & -- & - \\
\hline 1 & -0.98 & -4.68 & 2.25 & -0.685 & 13.987 & -0.600 & 0.16 & -2.31 & 0.07 \\
\hline LT & -0.01 & 13.65 & 1.60 & -0.614 & -2.015 & 1.174 & -7.44 & -1.58 & 2.25 \\
\hline LO & -3.81 & -3.38 & 4.31 & 0.258 & -18.84 & -1.498 & -6.49 & -3.03 & 1.42 \\
\hline 0 & 0.00 & 4.67 & -0.70 & -2.426 & 43.220 & -1.657 & 0.41 & -0.98 & -0.01 \\
\hline G & -- & -- & -- & 22.979 & 5.802 & -18.75 & 0.43 & -23.75 & 1.74 \\
\hline S & -3.57 & 89.43 & -4.38 & 7.993 & 45.133 & -20.19 & -0.24 & 2.35 & -0.04 \\
\hline LR & 0.43 & -46.31 & 4.04 & 0.258 & -18.84 & 1.498 & -24.14 & 62.48 & 41.45 \\
\hline SR & -8.17 & 141.37 & -5.21 & -6.625 & 34.105 & -0.083 & -18.27 & 39.25 & 0.60 \\
\hline $\mathrm{MW}$ & -2.23 & -3.79 & 9.20 & -11.644 & -21.62 & 17.280 & -14.56 & 10.03 & 2.50 \\
\hline MG & -- & -- & -- & -3.256 & -5.023 & 4.488 & -4.53 & -11.53 & 7.72 \\
\hline
\end{tabular}


In this case, the inertia values showed a $68.94,64.66$ and $90.82 \%$ of the chi squared for association between values is accounted by the first dimension, for $\mathrm{T} 1, \mathrm{~T} 2$ and T3, respectively. Dimension 2 also presents an important contribution except in T3. In T1 the highest partial contribution to these values comes from EG and $\mathrm{EH}$ for cloudy conditions, L, S and SR, while raining and L and $\mathrm{EH}$ for sunny conditions.

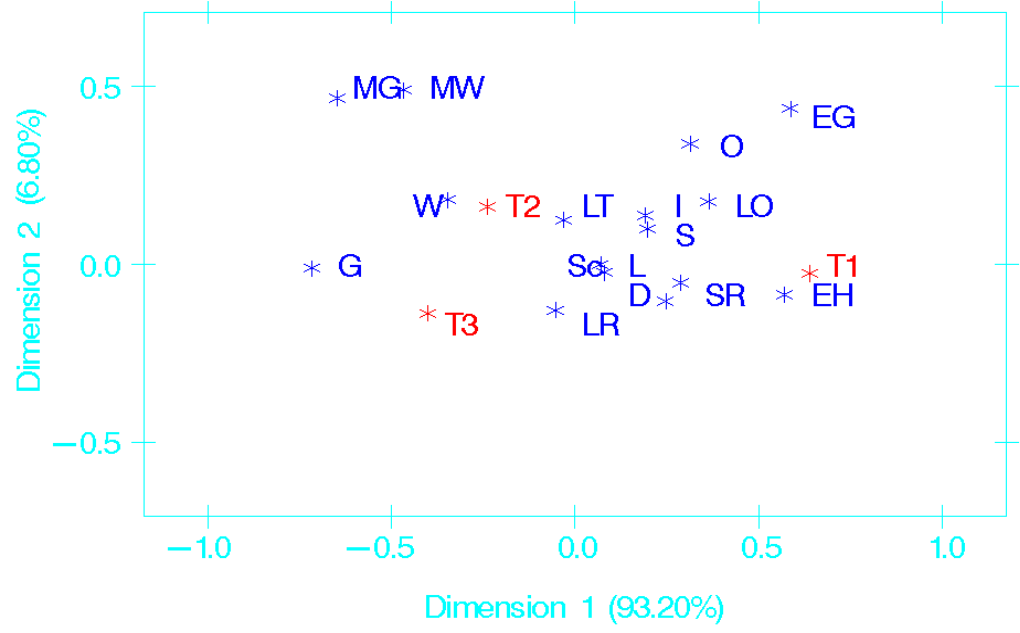

Figure $\mathbf{2}$ - Graphic representation of correspondence analysis of all behaviors observed:

drinking $(D)$, walking $(W)$, lying $(L)$, eating hay $(E H)$, eating grain $(E G)$, interactions $(I)$, licking themselves (LT), licking object (LO), grassing (G), standing (S), ruminant while lying $(\mathrm{LR})$, ruminant while standing (SR), moving to water (MW), moving to grassland (MG) and other (O); for treatments $\mathrm{T} 1, \mathrm{~T} 2$ and $\mathrm{T} 3$.

As it can be seen in Figure 3, dimension 1 in the plot separates the different weather conditions. This dimension indicates some differences in behavioral profiles mainly between sunny and rainy conditions. The second dimension, also explains more than $30 \%$ of the variables' correspondence, and mainly separates between weather conditions. In this treatment, behaviors like EH appears very close to cloudy weather, while SR and $O$ are more related to rainy weather. 
On the other hand, when the weather is sunny, animals are more likely to perform $L R, L, I$ and $L O$.

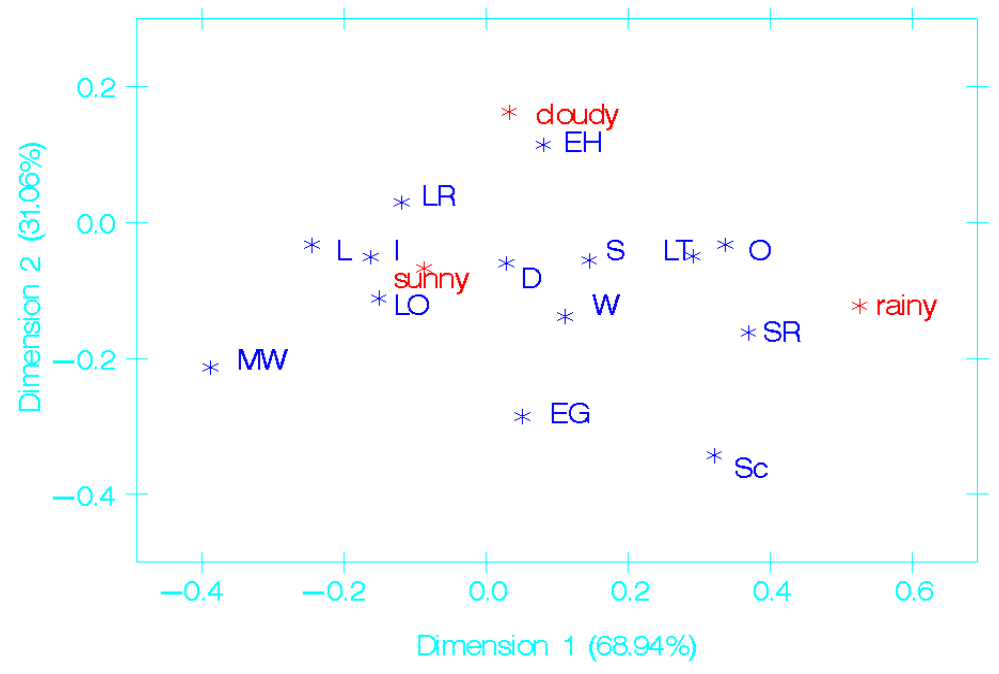

Figure 3 - Graphic representation of correspondence analysis of all behaviors observed:

drinking $(D)$, walking $(W)$, lying $(L)$, eating hay $(E H)$, eating grain $(E G)$, interactions $(I)$, licking themselves (LT), licking object (LO), grassing (G), standing (S), ruminant while lying $(\mathrm{LR})$, ruminant while standing (SR), moving to water (MW), moving to grassland (MG) and other $(\mathrm{O})$ and the weather condition in $\mathrm{T} 1$.

In T2 the highest partial contribution to inertia values comes from EG and $L$ for cloudy conditions and EG for rainy and sunny conditions. As it is displayed in Figure 4, both dimensions have an important contribution to the variables' correspondence. As it was explained above, the first dimension separates mainly rainy and sunny conditions, while the second dimension separates cloudy weather.

Certain behaviors such as Sc, SR and I, are closer to rainy weather, whereas animals under sunny conditions are more likely to perform MG, W, EG, D or MW. 
Despite the fact that $\mathrm{EH}$ is closer to Sunny, and $\mathrm{G}$ and $\mathrm{L}$ are near the cloudy weather, these behaviors present an intermediate positions between both weather conditions.

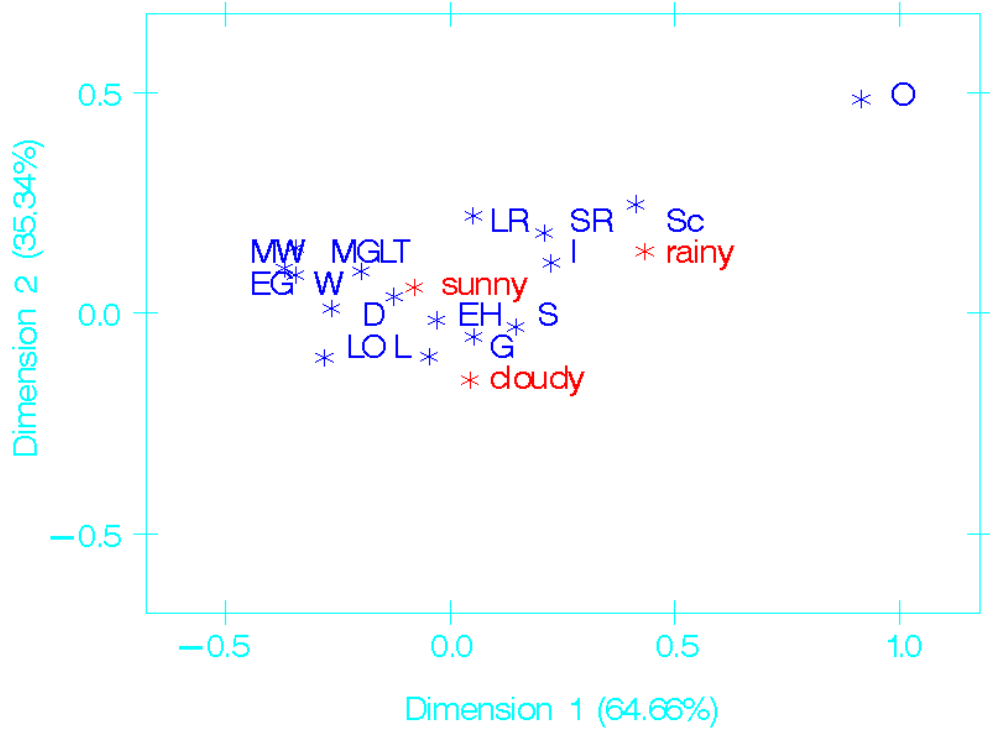

Figure 4-Graphic representation of correspondence analysis of all behaviors observed: drinking $(D)$, walking $(W)$, lying $(L)$, eating hay $(E H)$, eating grain $(E G)$, interactions $(I)$, licking themselves (LT), licking object (LO), grassing (G), standing (S), ruminant while lying (LR), ruminant while standing (SR), moving to water (MW), moving to grassland (MG) and other $(\mathrm{O})$ and the weather condition in $\mathrm{T} 2$.

Finally, the correspondence plot for $\mathrm{T} 3$ is shown in Figure 5 and according to the inertia values, $90.82 \%$ of the chi squared for association between values is accounted by the first dimension. As it was presented in Table 6, the highest partial contribution to inertia values comes from $\mathrm{EH}$ for all weather conditions. Dimension 1 separated the three weather conditions are separated, although sunny and rainy conditions are the furthest in this analysis. It is clear that in T3 animals were more likely to $\mathrm{EH}$ under rainy conditions, while $L$ and $L R$ were very 
close to sunny conditions. When the weather was cloudy, only low frequency behaviors were found to be associated to it, such as Sc, LT or D. In this case, G presented an intermediate position between sunny and cloudy conditions, but it was clearly separated from rainy weather.

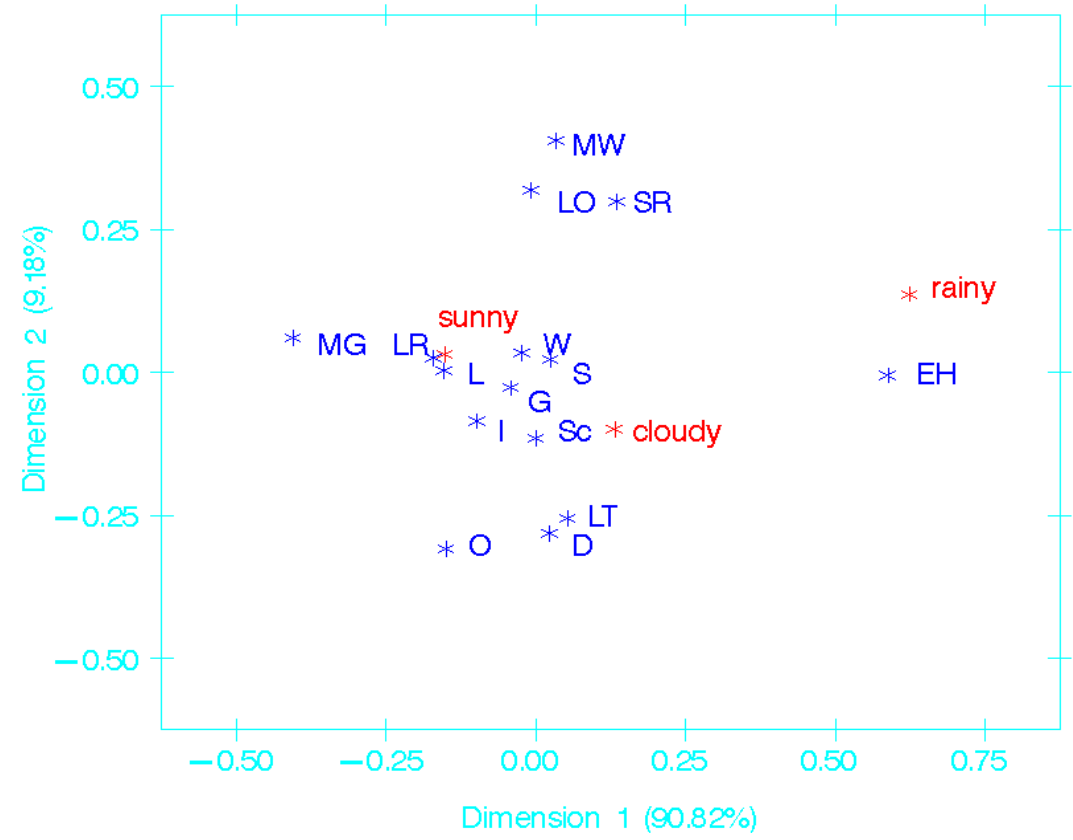

Figure $\mathbf{5}$ - Graphic representation of correspondence analysis of all behaviors observed: drinking (D), walking $(W)$, lying $(L)$, eating hay $(E H)$, eating grain $(E G)$, interactions (I), licking themselves (LT), licking object (LO), grassing (G), standing (S), ruminant while lying (LR), ruminant while standing (SR), moving to water (MW), moving to grassland (MG) and other $(\mathrm{O})$ and the weather condition in $\mathrm{T} 3$.

In Table 8 and Figure 6, 7 and 8, results of the correspondence analysis for temperature conditions are shown. In the case of temperature, according to the inertia values, contributions of the dimension 1 were $92.23,88.25$ and $66.49 \%$ of the chi squared for association between values, for $T 1, T 2$ and $T 3$, respectively. 
The dimension 2, only reported a relevant contribution in T3. According to Figure 6, in T1 dimension 1 discriminates between the behavioral profile of cold temperature from both warm and hot temperatures.

Table 8. Similarity values for each behavior: drinking (D), walking (W), lying (L), eating hay $(E H)$, eating grain (EG), interactions (I), licking themselves (LT), licking object (LO), grassing $(G)$, standing (S), ruminant while lying (LR), ruminant while standing (SR), moving to water $(\mathrm{MW})$, moving to grassland (MG) and other (O) under three temperature conditions for the three treatment (T1, T2 and T3)

\begin{tabular}{|c|c|c|c|c|c|c|c|c|c|}
\hline \multicolumn{4}{|c|}{ T1 } & \multicolumn{3}{|c|}{$\mathrm{T} 2$} & \multicolumn{3}{|l|}{ T3 } \\
\hline & Cold & Hot & Warm & Cold & Hot & Warm & Cold & Hot & Warm \\
\hline$D$ & 7.91 & 0.55 & -17.91 & -9.31 & 28.38 & -1.24 & -4.025 & 17.636 & -1.896 \\
\hline W & 1.91 & -6.94 & 0.50 & -11.33 & 15.32 & 0.36 & 18.756 & -30.38 & -0.107 \\
\hline $\mathrm{L}$ & - & 134.91 & 67.94 & 0.35 & 49.14 & -52.68 & 1.002 & 8.433 & -15.64 \\
\hline $\mathrm{EH}$ & 143.0. & -54.90 & -66.77 & 174.75 & - & -92.23 & -61.04 & 273.45 & -30.61 \\
\hline $\mathrm{EG}$ & 2.99 & -0.00 & -4.56 & -50.61 & -0.69 & 94.57 & -- & -- & -- \\
\hline I & 10.60 & -13.01 & -0.56 & 27.18 & - & -6.10 & 4.504 & -4.343 & -0.538 \\
\hline LT & 5.78 & -3.78 & -1.49 & 3.18 & -8.41 & 0.20 & 5.931 & -18.51 & 0.870 \\
\hline LO & 4.57 & -0.64 & -3.80 & 38.94 & - & -2.24 & 0.393 & -8.371 & 3.604 \\
\hline 0 & 4.09 & -1.94 & -1.56 & 12.33 & -0.83 & -12.76 & -1.143 & -3.005 & 8.726 \\
\hline G & -- & -- & -- & - & 42.22 & 355.57 & -8.457 & -49.63 & 104.00 \\
\hline$S$ & 6.21 & -1.04 & -4.79 & 314.30 & - & -197.3 & -8.680 & 13.517 & 0.084 \\
\hline LR & - & 1.60 & 122.06 & 0.43 & 0.85 & -2.82 & 93.622 & -15.98 & -71.47 \\
\hline$S R$ & 4.93 & -0.03 & -6.94 & 82.00 & - & -48.21 & 1.474 & -7.895 & 1.172 \\
\hline MW & 0.90 & -0.66 & -0.19 & -4.93 & 4.59 & 0.64 & -0.373 & -4.160 & 7.084 \\
\hline MG & -- & -- & -- & -12.47 & - & 69.34 & -0.925 & -8.487 & 15.322 \\
\hline
\end{tabular}


Analyzing values presented in Table 8, it can be seen that some behaviors such as $\mathrm{L}$ are positively associated to hot and $\mathrm{LR}$ to warm temperatures. $\mathrm{EH}$ was closer to cold temperature, and all active behaviors were closer to cold temperature than to warm or hot conditions.

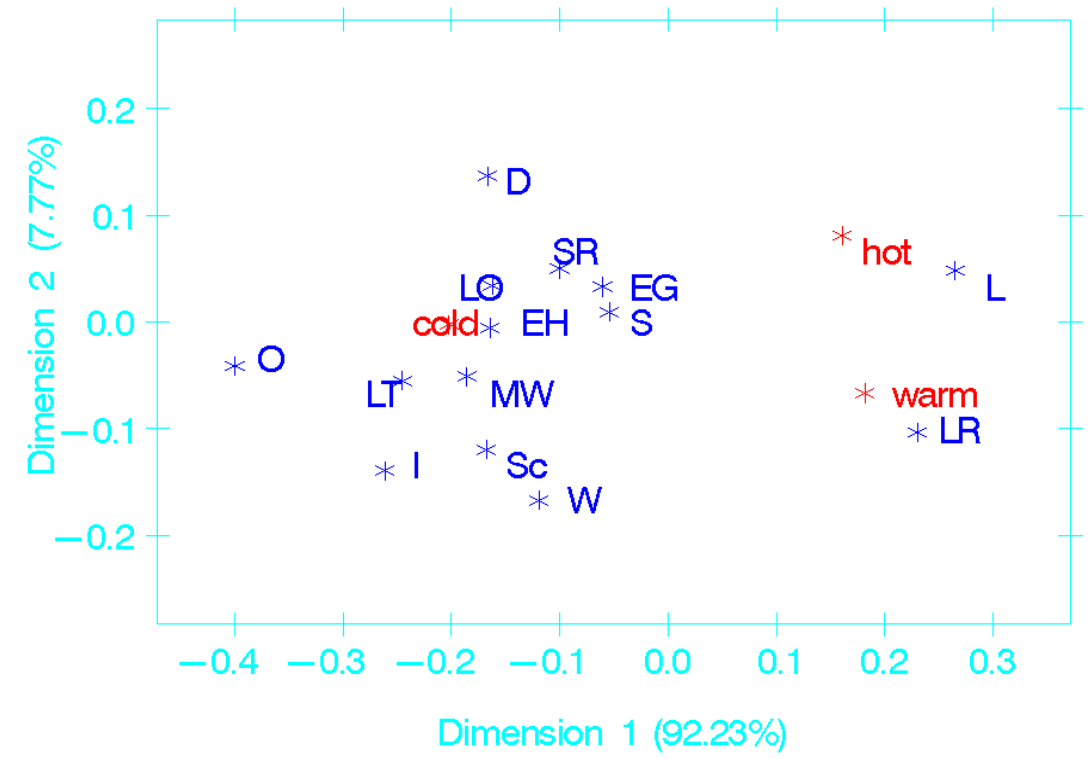

Figure 6 - Graphic representation of correspondence analysis of all behaviors observed: drinking $(D)$, walking $(W)$, lying $(L)$, eating hay $(E H)$, eating grain $(E G)$, interactions (I), licking themselves (LT), licking object (LO), grassing (G), standing (S), ruminant while lying $(L R)$, ruminant while standing (SR), moving to water (MW), moving to grassland (MG) and other $(\mathrm{O})$ and the environment temperature condition in $\mathrm{T} 1$

In T2 and according to Figure 7, dimension 1 separates the behavior profile of cold temperature from both warm and hot temperatures, although hot and warm in dimention 2 are presented more distant than in T1. In this treatment, $G$ and EG are very close to warm temperature, while $\mathrm{EH}, \mathrm{S}$ and $\mathrm{SR}$ are more related to cold. 
Otherwise, in hot weather, animals are more likely to perform W, MW and D. An intermediate situation between hot and cold, is shown for $L$ and $L R$.

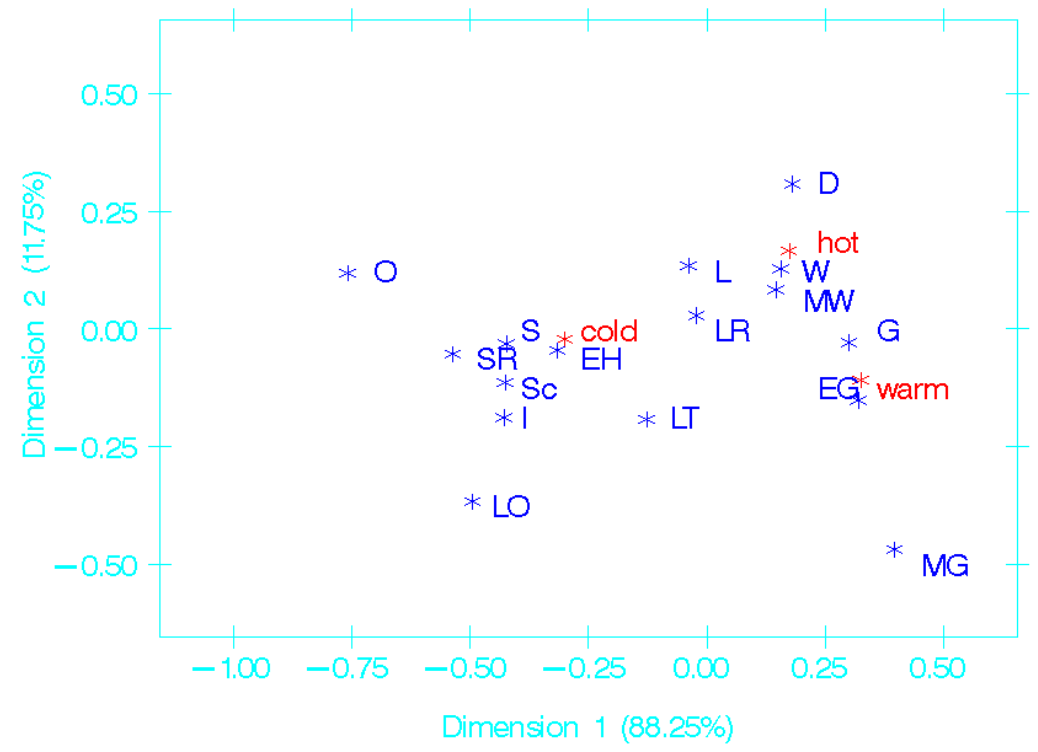

Figure 7 - Graphic representation of correspondence analysis of all behaviors observed: drinking (D), walking (W), lying (L), eating hay (EH), eating grain (EG), interactions (I), licking themselves (LT), licking object (LO), grassing (G), standing (S), ruminant while lying $(\mathrm{LR})$, ruminant while standing (SR), moving to water (MW), moving to grassland (MG) and other $(\mathrm{O})$ and the environment temperature condition in $\mathrm{T} 2$.

In the case of T3, as can be seen in Figure 8, dimension 2 explains a relevant part of the chi squared for association, although dimension 1 continues being the most important. For this treatment, dimension 1 separates hot temperature from warm and cold while the dimension 2 separates the three temperature conditions. In this case, EH and D are very close to hot temperature. During warm conditions, steers were more likely to perform $G$, while LR is shown associated to cold temperature. 
In all treatments, $\mathrm{O}$ appeared separated from most of the behaviors and with a low relationship with the weather conditions.

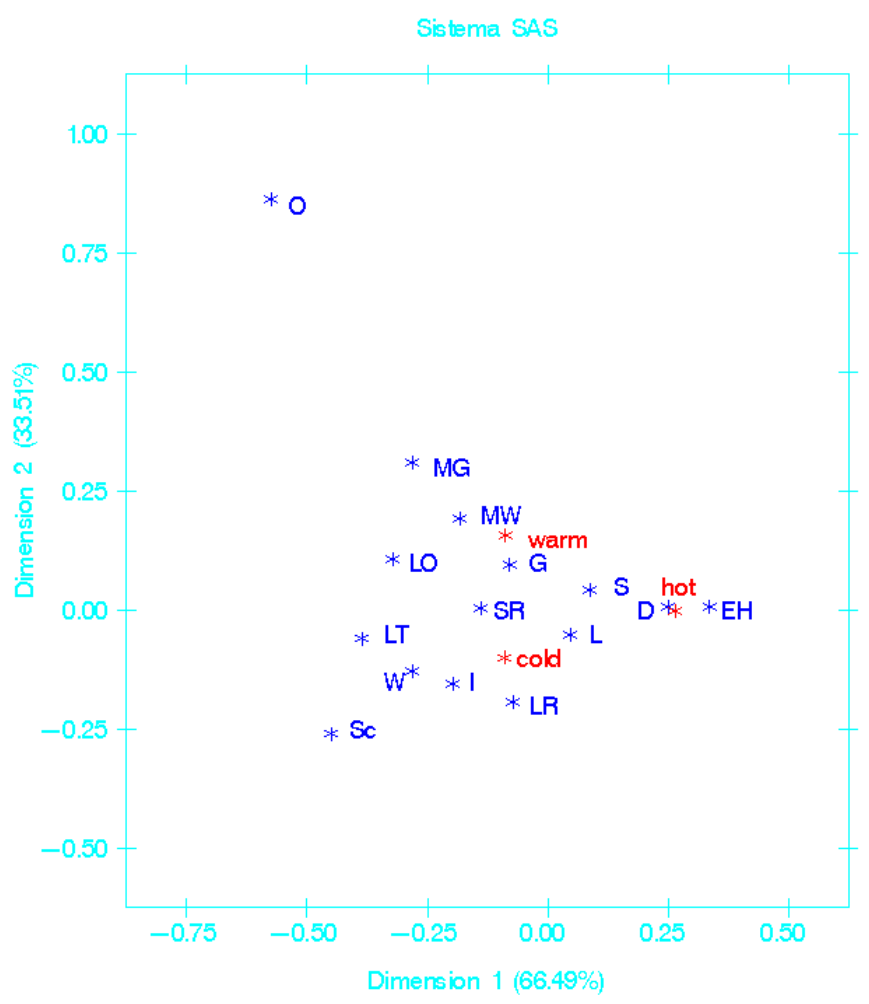

Figure 8 - Graphic representation of correspondence analysis of all behaviors observed:

drinking $(D)$, walking $(W)$, lying $(L)$, eating hay $(E H)$, eating grain $(E G)$, interactions $(I)$, licking themselves (LT), licking object (LO), grassing (G), standing (S), ruminant while lying $(L R)$, ruminant while standing $(S R)$, moving to water (MW), moving to grassland (MG) and other $(\mathrm{O})$ and the environment temperature condition in $\mathrm{T} 3$.

\section{Discussion}

\subsection{Behavior frequency.}

According to the results obteined, grazing was the most registered activity in $\mathrm{T} 2$ and T3, taking into account that this behavior could not be performed in T1. There 
are several factors affecting grazing behavior, such as breeds, age or body size (Fraser et al., 2009) but it always occupies an important proportion of the time, and similar values to our results are reported (Orr et al., 2004; Hessle, 2009). Other studies show even higher proportion of the time spent in this activity. For example, Hejcmanová et al. (2009) found 54\% of the time for intensive grazing and $52 \%$ for extensive grazing and Huber et al. (2008) reported percentages around $70 \%$ in animals with pure grazing feeding. One singular thing which shows the importance of grazing in animal behavior is the minimum difference between $\mathrm{T} 2$ and T3 for this behavior (6.5\%). That means that although in T2 animals only had half of the time access to grassland as compared to T3, they performed it more intensively. In addition, in T3 for the IN period, the proportion of animals reported as G was lower than in the OUT period. Considering both findings, animals in T2 look like having an intensification of grazing during the access period as compensation for the restriction during the rest of the day. This effect has been previously reported for deprivation in dairy cows, which promoted increases in instantaneous intake rate by increments of grazing time, bite mass, and bite rate (Chilibroste et al., 2007; Patterson et al., 1998). Considering total time destined to eating behavior (E) in T1 was lower than in T3, as reported O'Driscoll et al. (2009). These results could be explained by an increase of chewing promoted for eating green forage, which is a consequence of higher water contents in relation with hay and grains (Galli et al., 2006). The low importance of EG in the total time destined to eating behaviors, was because of animals did not have free access to grain. It was supplied at specific periods of the day, consumed in a few minutes, increasing its frequency for those moments.

On the other hand, $L$ resulted similar for all treatments, so the restricted space in T1 did not affect the availability of resting places enough to affect this behavior, 
although it is necessary to remark the relative high space allowance in T1 as compared to space allowance reported by other authors (Gupta et al., 2008; Cozzi et al., 2009; Absmanner et al., 2009; Platz et al., 2007; Manninen et al., 2007; Napolitano et al., 2004). Considering LR, it represents an increase of lying time. Taking into account that resting is an important behavior to improve calves welfare (Faerevik et al., 2008) and ruminating occupies a important part of resting time (Plesch et al., 2010), in the present work lying time seems as not affecting animal welfare.

In general, high LR was expectable for diets with pasture as main feeding source, but no differences were found between treatments. However, considering IN period, in $\mathrm{T} 2$ there was a significant fall in LR time which was probably caused by the intensification of $G$ and consequently the lower time availability. Different situation occurs in OUT period, where T2 increased LR in relation to IN period and showed not differences with T3. This can be explained as the animal performing the normal time of LR behavior as a result of the disappearance possibility of doing grazing which release time for other activities.

On the contrary, SR is considered as discomfort evidence more than a component of nutritional behavior conditions, (Low et al., 1981), so animals in T1 can be reflecting a lower possibility of finding comfortable positions. However, the reduction of $S R$ in $T 2$ for period IN, reflects that this behavior can be also be restricted because of grazing priority.

Similar analysis can be done for E behavior, which followed the same pattern, presenting no difference between OUT and IN periods for T3. However, it increased considerably in $\mathrm{T} 2$ as a consequence of grazing intensification in the IN period. Conversely, in the OUT period the reduction of total eating frequency for T2 was severe, resulting in lower values than those showed for T3. To our 
knowledge, this can be interpreted as a reduction, during OUT period in the ingestion requirements which have to be satisfied, as animals spent many time eating and grazing during IN period. This implies a reduction of time devoted to eat during OUT, as well as the need to perform other activities which were impaired during IN.

\subsection{Logistic regression. Daily patterns}

The proportion of time destined to each behavior could be a way to determine the importance of the different behaviors. However, some behavior that represents a low proportion of the total time, can be important due to their association with a specific production system, and then they become important in its characterization. This is the case of $D$, which has a low probability of occurrence in all treatments, but it is higher in $\mathrm{T} 1$, probably associated with feeding sources which had a higher dry matter concentration (Kume et al, 2010). This hypothesis is confirmed by the increasing tendency along the day, following the EH evolution.

There are also behaviors which have the same daily pattern in the three systems, like the case of $L$. In all treatments, $L$ increases during the day, which could be a consequence of the increased temperature (Gonyou et al., 1979), also pointed out in the correspondence analysis and the reduction of soil humidity caused by dew (Graunke et al., 2011; Wassmuth et al., 1999). The decreasing tendency of dry matter intake from morning to afternoon presented by van Dorland et al. (2008) and Zobel et al. (2011) for cows, was found in our study in T2 and T3 when EH was observed. Nevertheless, this behavior in T1 was probably drastically reduced at the beginning of the observation period as consequence of the grain supply so $\mathrm{EH}$ was low at the first hours and was increased later. In T1 there was also a higher probability of observing animals ruminating while standing. As it has been 
discussed, SR is associated with animal discomfort, and then, the decreasing tendency was probably caused by the increase of temperature and decrease of humidity of the soil along the day. In this sense, the drinking (D) pattern in T1 showed an increasing probability along the day, which is associated with $\mathrm{EH}$ tendency. Drinking behavior is stable for T2 and T3 in which animals had a diet with higher water content, as indoor animals present higher drinking times than those which were in pastures (Charlton et al., 2011) which coincides with our results.

Grazing was the main activity in T2 and T3, and it is probably affected by environmental conditions. These conditions are normally improved along the day in spring, increasing temperature while decreasing humidity, which stimulate steers activity (Graunke et al., 2011), which could explain the tendency of T3. Other possible explication is the pasture increase of DM and soluble carbohydrates in the afternoon (Orr et al., 2001), this reason was cited by Charlton et al. (2011) as explication of preference for pasture in the afternoon in relation to morning for dairy cows.

Finally, LR showed higher values and increasing tendency along the day in T3 than in $T 1$ and $T 2$. If total ruminating $(L R+S R)$ is integrated, a decreasing tendency is observed for T1 and T2, while T3 would maintain an increasing tendency but not as intense as the observed for LR. T1 and T2 are according with Deswysen et al. (1997) for Hereford steers, although treatments did not include fresh pasture in diet. In addition, when grazing is intensified, there is a reduction in ruminating time (Chilibroste et al., 2007; Gregorini et al., 2009), which could explain the differences between $\mathrm{T} 2$ and $\mathrm{T} 3$. 


\subsection{Correspondence analysis}

Correspondence analysis became a useful tool to interpret certain behaviors. EG is conditioned by management, due to isolated supply of grain and the immediate intake by the animals. In this case, the closer relation to determinate weather or temperature conditions is function of the situations observed at the moment of feeding and not the contrary.

In general, the association between low occurrence and unspecific behaviors (such as MW, MG, $\mathrm{O}$, or $\mathrm{Sc}$ ) and treatments or weather conditions might be considered fortuitous, and in most of the presented plots these behaviors appear separated from the rest.

Conversely, this analysis tended to keep T1 away from T2 and T3 when other behaviors which represent the main time use of animals are considered. Relative to this, the impossibility to perform $\mathrm{G}$ in $\mathrm{T} 1$, turns $\mathrm{EH}$ into the main feeding behavior and then, it appears very close to this treatment in the plots. If this behavior is analyzed separately by each treatment, its association with cold temperature and rain absence is notorious. This is associated with an increase of energy needs with cold temperatures (Fox et al., 1988) and rain absence, which is associated a stimulating conditions to increase feed intake (Graunke et al., 2011). However, in $\mathrm{T} 3, \mathrm{EH}$ is more related to hot temperature and rainy weather, although this behavior is probably caused by a different situation: during rain events or in the hottest hours of the day, animals tended to be grouped in a small zone near the hay supplier and water through, were they seemed to feel more protected. In this situation, animals were likely to eat hay, while group stayed in this area.

Animals were more likely to perform $G$ under warm temperatures, which are considered the more comfortable conditions, and it is apparently indifferent of 
sunny or cloudy weather. On the contrary, animals do not tend to $G$ under rainy conditions, which is in agreement with Graunke et al. (2011), who found a negative influence of rain on grazing behavior. Animals while raining are more likely to ruminate or looking for refuge, than fed. This behavior resulted also mainly related to $T 3$ followed by $T 2$, which reinforces the importance of $G$ in the limited period of access to grassland.

In the case of LR, the relation with treatments confirms the substitution of this behavior for intensifying grazing in T2 treatment. Considering that LR is an important behavior related to nutrition, adjusting grazing time could resolve this restriction. The weather conditions affect in a similar way to the three treatments, where LR is a behavior associated with not rainy conditions. Nevertheless, the association between temperature and this behavior is different among treatments and it seems to be more conditioned to other behaviors. In this instance, $L$ is in an opposite position to the main feeding behaviors ( $E G$ and $G$ ) in the three treatments, so it could be influenced by fibrous feed intake as reported by Chilibroste et al. (2007) and Deswysen et al. (1997). Regarding to SR, it appears closer to extreme temperature or rainy weather for all treatments, which reinforces the association of this behavior to poor comfort conditions.

Finally, L was related to sunny or cloudy conditions, in opposition to rainy weather. Rain causes wet ground, which is an inhibition to lying behavior (Gonyou et al., 1979; Graunke et al., 2011). And besides, animals in T1 and T2 were less likely to rest in cold temperature as previously reported by Gonyou et al. (1979). However, due to the fact that animals were grazing in T3 more frequently under warm temperature, $\mathrm{L}$ was limited in those conditions and then it was more associated to hot temperatures. In consecuence, in hot periods, both $L$ favourable 
conditions are present, steers are not so likely to graze and the ground had a low humidity level.

\section{Conclusions}

The management conditions associated to the studied systems produced different behavioral patterns in the animals but no evidence of abnormal behavior has been detected. The environmental conditions also affected in different ways to the animals involved in each system. Rain affected resting comfort in confined animals and reduced grazing time in animals with pasture access, modifying the behavioral pattern. Animals in total or partially confined system, associated their eating behavior to temperature, but when animals were permanently in grassland, grazing behavior was more associated with comfortable conditions.

Nutritional related behavior occupied most of the time in all the systems. Grazing behavior is important for the animals and the permanent or restricted possibility to perform it (determined by the production system itself), changes the patterns of other behaviors in order to give priority to pasture intake. Some handling or infrastructure changes could be practical decisions in order to modify behavior patterns in any of the studied systems. Providing a covered area for protecting of the weather and feeding supplements strategically supplied could improve the possibilities of the animals of coping with environmental conditions. 


\section{References}

Absmanner, E., Rouha-Mülleder, C., Scharl, T., Leisch, F. and Troxler, J. (2009). Effects of different housing systems on the behavior of beef bulls--An on-farm assessment on Austrian farms. Applied Animal Behavior Science 118(1-2), 1219.

Andrighetto, I., Gottardo, F., Andreoli, D. and Cozzi, G. (1999). Effect of type of housing on veal calf growth performance, behavior and meat quality. Livestock Production Science 57(2), 137-145.

Ayantunde, A. A., Fernández-Rivera, S., Hiernaux, P. H. Y., van Keulen, H., Udo, H. M. J. and Chanono, M. (2001). Effect of timing and duration of grazing of growing cattle in the west african sahel on diet selection, faecal output, eating time, forage intake and live-weight changes. Animal Science 72(1), 117-128.

Ayantunde, A. A., Fernández-Rivera, S., Hiernaux, P. H. and Tabo, R. (2008). Implications of restricted access to grazing by cattle in wet season in the Sahel. Journal of Arid Environments 72(4), 523-533.

Babu, L. K., Pandey, H. N. and Sahoo, A. (2004). Effect of individual versus group rearing on ethological and physiological responses of crossbred calves. Applied Animal Behavior Science 87(3-4), 177-191.

Bak Jensen, M., Vestergaard, K. S., Krohn, C. C. and Munksgaard, L. (1997). Effect of single versus group housing and space allowance on responses of calves during open-field tests. Applied Animal Behavior Science 54(2-3), 109-121.

Bokkers, E. A. M. and Koene, P. (2001a). Activity, oral behavior and slaughter data as welfare indicators in veal calves: a comparison of three housing systems. Applied Animal Behavior Science 75(1), 1-15. 
Bokkers, E. A. M. and Koene, P. (2001b). Activity, oral behavior and slaughter data as welfare indicators in veal calves: a comparison of three housing systems. Applied Animal Behavior Science 75(1), 1-15.

Broom, D. M. and Johnson, K. G. (1993). Stress and animal welfare.Editors: Chapman \& Hall. London, pp. 1-207.

Charlton, G. L., Rutter, S. M., East, M. and Sinclair, L. A. (2011). Preference of dairy cows: Indoor cubicle housing with access to a total mixed ration vs. access to pasture. Applied Animal Behavior Science 130(1-2), 1-9.

Chilibroste, P., Soca, P., Mattiauda, D. A., Bentancur, O. and Robinson, P. H. (2007). Short term fasting as a tool to design effective grazing strategies for lactating dairy cattle: A review. Australian Journal of Experimental Agriculture 47(9), 1075-1084.

Deswysen, A. G., Dutilleul, P., Fischer, V. and Campbell, C. P. (1997). Quantitative analysis of nycterohemeral eating and ruminating patterns in beef cattle fed pelleted concentrates with or without supplemental roughage. Canadian Journal of Animal Science 77(3), 375-384.

DIEA. (2010). Anuario Estadístico 2010. MGAP. Montevideo.

Faerevik, G., Tjentland, K., Lovik, S., Andersen, I. L. and Boe, K. E. (2008). Resting pattern and social behavior of dairy calves housed in pens with different sized lying areas. Applied Animal Behavior Science 114(1-2), 54-64.

Fox, D. G., Sniffen, C. J. and O'Connor, J. D. (1988). Adjusting Nutrient Requirements of Beef Cattle for Animal and Environmental Variations. Journal of Animal Science 66(6), 1475-1495. 
Fraser, D., Weary, D. M., Pajor, E. A. and Milligan, B. N. (1997). A scientific conception of animal welfare that reflects ethical concerns. Animal Welfare 6, 187-205.

Fraser, M. D., Davies, D. A., Vale, J. E., Nute, G. R., Hallett, K. G., Richardson, R. I. and Wright, I. A. (2009). Performance and meat quality of native and continental cross steers grazing improved upland pasture or semi-natural rough grazing. Livestock Science 123(1), 70-82.

Galli, J. R., Cangiano, C. A., Demment, M. W. and Laca, E. A. (2006). Acoustic monitoring of chewing and intake of fresh and dry forages in steers. Animal Feed Science and Technology 128(1-2), 14-30.

Garner, J. P. (2005). Stereotipies and Other Abnormal repetitive Behaviors: Potential Impact on Validity, Reliability, and Replicability of Scientific Outcomes. ILAR Journal 46(2), 106-117.

Gonyou, H. W., Christopherson, R. J. and Young, B. A. (1979). Effects of cold temperature and winter conditions on some aspects of behavior of feedlot cattle. Applied Animal Ethology 5(2), 113-124.

Graunke, K. L., Schuster, T. and Lidfors, L. M. (2011). Influence of weather on the behavior of outdoor-wintered beef cattle in Scandinavia. Livestock Science 136(2-3), 247-255.

Gregorini, P., Clark, C. E. F., Jago, J. G., Glassey, C. B., McLeod, K. L. M. and Romera, A. J. (2009). Restricting time at pasture: Effects on dairy cow herbage intake, foraging behavior, hunger-related hormones, and metabolite concentration during the first grazing session. Journal of Dairy Science 92(9), 4572-4580. 
Gupta, S., Earley, B., Nolan, M., Formentin, E. and Crowe, M. A. (2008). Effect of repeated regrouping and relocation on behavior of steers. Applied Animal Behavior Science 110(3-4), 229-243.

Hejcmanová, P., Stejskalová, M., Pavlu, V. and Hejcman, M. (2009). Behavioral patterns of heifers under intensive and extensive continuous grazing on species-rich pasture in the Czech Republic. Applied Animal Behavior Science 117(3-4), 137-143.

Hepola, H., Hänninen, L., Pursiainen, P., Tuure, V. M., Syrjälä-Qvist, L., Pyykkönen, M. and Saloniemi, H. (2006). Feed intake and oral behavior of dairy calves housed individually or in groups in warm or cold buildings. Livestock Science 105(1-3), 94-104.

Hessle, A. K. (2009). Effects of social learning on foraging behavior and live weight gain in first-season grazing calves. Applied Animal Behavior Science 116(2-4), 150-155.

Huber, R., Baumung, R., Wurzinger, M., Semambo, D., Mwai, O. and Winckler, C. (2008). Grazing, social and comfort behavior of Ankole and crossbred (AnkoleáláHolstein) heifers on pasture in south western Uganda. Applied Animal Behavior Science 112(3-4), 223-234.

Kume, S., Nonaka, K., Oshita, T. and Kozakai, T. (2010). Evaluation of drinking water intake, feed water intake and total water intake in dry and lactating cows fed silages. Livestock Science 128(1-3), 46-51.

Kondo, S., Sekine, J., Okubo, M. and Asahida, Y. (1989). The effect of group size and space allowance on the agonistic and spacing behavior of cattle. Applied Animal Behavior Science 24(2), 127-135. 
Low, W. A., Tweedie, R. L., Edwards, C. B. H., Hodder, R. M., Malafant, K. W. J. and Cunningham, R. B. (1981). The influence of environment on daily maintenance behavior of free-ranging Shorthorn cows in central Australia. III. Detailed analysis of sequential behavior patterns and integrated discussion. Applied Animal Ethology 7(1), 39-56.

Manninen, M., Sankari, S., Jauhiainen, L., Kivinen, T. and Soveri, T. (2007). Insulated, uninsulated and outdoor housing for replacement beef heifers on restricted grass silage-based diet in a cold environment. Livestock Science 107(2-3), 113-125.

Mench, J. A. and Mason, G. J. (2005). Behabiour. Edición: Appleby, M. C. y Hughes, B. O. En: Animal welfare.

Mohan Raj, A. B., Moss, B. W., McCaughey, W. J., McLauchlan, W., Kilpatrick, D. J. and McGaughey, S. J. (1991). Behavioral response to mixing of entire bulls, vasectomised bulls and steers. Applied Animal Behavior Science 31(3-4), 157168.

Morisse, J. P., Huonnic, D., Cotte, J. P. and Martrenchar, A. (2000). The effect of four fibrous feed supplementations on different welfare traits in veal calves. Animal Feed Science and Technology 84(1-2), 129-136.

Napolitano, F., De Rosa, G., Grasso, F., Pacelli, C. and Bordi, A. (2004). Influence of space allowance on the welfare of weaned buffalo (Bubalus bubalis) calves. Livestock Production Science 86(1-3), 117-124.

O'Driscoll, K., Boyle, L. and Hanlon, A. (2009). The effect of breed and housing system on dairy cow feeding and lying behavior. Applied Animal Behavior Science 116(2-4), 156-162. 
Orr, R. J., Rutter, S. M., Penning, P. D. and Rook, A. J. (2001). Matching grass supply to grazing patterns for dairy cows. Grass and Forage Science 56(4), 352361.

Orr, R. J., Rutter, S. M., Yarrow, N. H., Champion, R. A. and Rook, A. J. (2004). Changes in ingestive behavior of yearling dairy heifers due to changes in sward state during grazing down of rotationally stocked ryegrass or white clover pastures. Applied Animal Behavior Science 87(3-4), 205-222.

Patterson, D. M., McGilloway, D. A., Cushnahan, A., Mayne, C. S. and Laidlaw, A. S. (1998). Effect of duration of fasting period on short-term intake rates of lactating dairy cows. Animal Science 66(2), 299-305.

Petherick, J. C. (2005). Animal welfare issues associated with extensive livestock production: The northern Australian beef cattle industry. Applied Animal Behavior Science 92(3), 211-234.

Phillips, C. J. C. (2004). The Effects of Forage Provision and Group Size on the Behavior of Calves. Journal of Dairy Science 87(5), 1380-1388.

Platz, S., Ahrens, F., Bahrs, E., N³ke, S. and Erhard, M. H. (2007). Association between floor type and behavior, skin lesions, and claw dimensions in grouphoused fattening bulls. Preventive Veterinary Medicine 80(2-3), 209-221.

Plesch, G., Broerkens, N., Laister, S., Winckler, C. and Knierim, U. (2010). Reliability and feasibility of selected measures concerning resting behavior for the onfarm welfare assessment in dairy cows. Applied Animal Behavior Science 126(1-2), 19-26.

Ruggia, A., Montossi, F., Albin, A., Blumetto, O., Brito, G. and Rodríguez, A. (2011). Una oportunidad de incrementar la Productividad Ganadera Nacional: 
Producción intensiva de carne con animales Holando. Serie Técnica, INIA. Canelones.

SAS Institute Inc. (2008). SAS/STAT 9.2. User's Guide, SAS Institute Inc., Cary, NC (2008).

Simeone, A. and Berreta, V. (2007). La invernada en los tiempos de la soja: ¿La hora del feedlot?". Jornada Anual de la UPIC. Paysandú, Facultad de Agronomia UDELAR.

Stricklin, W. R. and Kautz-Scanavy, C. C. (1984). The role of behavior in cattle production: A review of research. Applied Animal Ethology 11(4), 359-390.

van Ackeren, C., Steinga', H., Hartung, K., Funk, R. and Drochner, W. (2009). Effect of roughage level in a total mixed ration on feed intake, ruminal fermentation patterns and chewing activity of early-weaned calves with ad libitum access to grass hay. Animal Feed Science and Technology 153(1-2), 48-59.

van Dorland, H. A., Kreuzer, M., Leuenberger, H. and Wettstein, H. R. (2008). Eating behavior of dairy cows offered fresh or ensiled white clover, red clover and ryegrass to choose from or in a mixture. Applied Animal Behavior Science 111(3-4), 205-221.

Verbeke, W., Pérez-Cueto, F. J. A., Barcellos, M. D., Krystallis, A. and Grunert, K. G. (2010). European citizen and consumer attitudes and preferences regarding beef and pork. Meat Science 84(2), 284-292.

Verbeke, W. and Viaene, J. (1999). Beliefs, attitude and behavior towards fresh meat consumption in Belgium: empirical evidence from a consumer survey. Food Quality and Preference 10(6), 437-445. 
Wassmuth, R., Wallbaum, F. and Langholz, H.-J. (1999). Outdoor wintering of suckler cows in low mountain ranges. Livestock Production Science 61(2-3), 193-200.

Zobel, G., Schwartzkopf-Genswein, K. S., Genswein, B. M. A. and von Keyserlingk, M. A. G. (2011). Impact of agonistic interactions on feeding behaviors when beef heifers are fed in a competitive feeding environment. Livestock Science 13(1-3), 1-9. 



\section{Capítulo 3}

Productive, physiological and social behaviour characterization, of three contrasting production systems of Holstein steers. 



\section{Abstract}

Despite intensive systems are normally associated to worse welfare status, conditions associated with extensive livestock production could also create a substantial number of welfare problems. The main objective of the present study is to characterize three different Holstein steers' production systems, throw their effect of on productive traits, physiological indicators and social interactions. 48 Holstein castrated males, were randomly divided into three groups, corresponding to three treatments: (T1) confined into a 210 square meters yard, (T2) confined into a similar yard with six hours of access to grassland, (T3) permanently placed at grassland. Live weight gain (LWG) and food dry matter intake (DMI) were measured, and $\mathrm{N}$ intake (NI) and feed efficiency (FE) estimated. Social behaviour was registered continuously, during twelve hours a day (from 7:00 to 19:00), three days per week, in four weeks distributed throughout the experiment. Blood samples were taken to determine cortisol level and biochemical profile. No differences were detected for LWG, but T1 had the best FE by reducing the $\mathrm{DMI}$ as compared to $\mathrm{T} 2$ and $\mathrm{T} 3$. Negative interactions were higher in $\mathrm{T} 1 \quad(\mathrm{P}<0.0001)$. Average cortisol concentration did not show differences $(P=0.7189)$. There are no evidences of increasing stress or health problems in any production system, although it has to be taken in account that permanent confined animals increased agonistic behaviour, which probably reflects some welfare problems. Productivity was similar, although feed and $\mathrm{N}$ utilization must to be deeply studied in these systems. 



\section{Introduction}

Beef production in Uruguay is one of the most important rural economic activities. It is mainly based on grazing systems, which occupy more than $60 \%$ of the country's territory (DIEA, 2010). However, in the last years due to competence for land with cereal crops, intensive production systems have been developed, with an increase of confined production (Palma, 2008). Feedlot production represents nowadays around $5-6 \%$ of total slaughter, and it is expected to continue growing (Realini et al., 2009).

On the other hand, the country has performed an important marketing effort in order to present to consumers the organoleptic quality, but also the social, environmental and ethical benefit of grassland-based beef production (Blasina, 2010). Another driving force in the south of the country is dairy production, due to the increasing cattle stock, which makes male Holstein calves economically available for meat production. In dairy production systems, grazing and grain supplementation are well known by producers, and consequently, some alternatives of calves fattening, which combine characteristics of both confined and grazing systems, have been developed (Ruggia et al., 2011). In addition, as consumers became more concerned about farm animal welfare (Bennett et al., 2000), the development of alternative housing systems for beef production becomes more and more important (Absmanner et al., 2009).

By contrast, the intensive production systems modify animal conditions, by reducing their space allowance, changing feeding and resting conditions, and influencing social behaviour (Kondo et al., 1989). Subsequently, competition for resources such as food or attractive resting places may cause aggression and social stress (Purcell and Arave, 1991) 
One of these aspects, insufficient space allowance, induces a repeated state of stress that alters the activity of the pituitary-adrenal axis, immune function, behaviour and growth rate (Fisher et al., 1997a). Average daily gain is reduced and cortisol blood concentration increases with restricted space allowance (Gupta et al., 2007). Diet in finishing steers has been found as affecting cortisol levels as well (Larraín et al., 2008).

Animal health is one of the most important aspects considered to evaluate welfare (Broom, 2006) and biochemical serum profile is a common method to assess it (Adams et al., 2008; Chorfi et al., 2007). Some blood parameters such as glucose or creatin kinase, are used as stress indicators (Bonacic et al., 2006). Elevation of their plasma concentrations reflects alterations in tissue function or indicates cell damage or necrosis (SCAHAW, 2000). In addition, plasma activities CK is sign of stress-induced tissue damage (Hocking et al., 1994; Cardinet III, 1997) or skeletal muscle lesions attributable to trauma or vigorous exercise (Idexx, 2006).

Despite intensive systems are normally associated to worse welfare status, conditions associated with extensive livestock production could also create a substantial number of welfare problems (Petherick, 2005). This makes the study of different effects of each production system on social and welfare aspects crucial.

The main objective of the present study is to characterize three different Holstein steers' production systems, throw their effect of on productive traits, physiological indicators and social interaction. Studied systems represent the traditional system used in Uruguay with exclusive grazing animals, a new developed confined systems and a new one, that combine confined and grazing periods. 


\section{Materials and methods}

The experiment was carried out at Las Brujas Experimental Centre of the National Agricultural Research Institute (INIA) of Uruguay (34040'S lat, 5620'W, $36 \mathrm{~m}$ alt). The experimental period lasted 133 days, from August 4 to December 16 of 2008.

\subsection{Animals and housing}

Experimental design was established according to (Manninen et al., 2007). Forty eight Holstein castrated males (mean live weight at start $93 \pm 20.3 \mathrm{~kg}$ ), were randomly divided into three groups (16 calves each) corresponding to three treatments:

(T1) confined into a 210 square meters yard,

(T2) confined into a 210 square meters yard with six hours of access to grassland,

(T3) permanent placed at grassland.

All animals were individually identified in the ear (number id) and in each group, different colour collars were used for each animal, in order to help individualizing in behaviour studies. All experimental measurements started on September 15, after an adaptation period of 43 days.

The experimental yards (treatments T1 and T2) consisted on an outdoor $21 \times 10 \mathrm{~m}$ yard, built with electric fencing. The grassland parcels were also built with electric fencing, and the surface was calculated depending on the forage offered to reach $8 \%$ of average live weight per animal. Average surface was about 2000 square meters.

Animals assigned to T1 were permanently placed in the yard with automatic water trough and fed ad libitum with alfalfa hay. Twice a day (at 9:00 and 16:00), sorghum humid grain silage ( $2 \%$ of average live weight) and sunflower and 
soybean expeller, were supplied. Animals assigned to T2 were placed in the yard with an automatic water trough, fed ad libitum with alfalfa hay and sorghum humid grain silage ( $1.5 \%$ of average live weight) supplied in a unique moment at 16:00. In addition, they were moved six hours per day (10:00 to 16:00) to a grassland parcel with an additional trough. Calves in T3 were permanently in grassland, with free availability of alfalfa hay and water. Pasture offered was a mix of alfalfa, red clover and ryegrass.

\subsection{Production measures}

Animals were individually weighed every two weeks. Average daily gain was calculated by dividing total weight gain in the measured period by total days in that period. Provided feed per group was weighed every day and then, food intake of each group was weekly measured for hay and grain supplement. Pasture intake was calculated as the difference between offering (availability at the moment of opening a new grazing parcel) and remaining (availability at the moment of taking out the animals of the parcel) with an standard method (Moliterno, 1997). To this effect, 7 samples were taken in each grazing parcel before the animal income and after closing parcels. Dry matter (DM) content in the pasture was estimated by freeze-dried in pooled herbage samples for 48 hours at $60^{\circ} \mathrm{C}$. Hay and supplement DM was determined by drying at $80^{\circ} \mathrm{C}$ for 24 hours and nitrogen content of pasture, hay and supplement were analyzed by Kjeldahl method.

In addition, feed conversion rate for each group was calculated by dividing total DM intake by the total individual weight gain.

Total $\mathrm{N}$ intake was calculated as the DM intake multiplied by this calculated $\mathrm{N}$ content and the proportion (\%) of $\mathrm{N}$ in total intake, was obtained by the following 
equation: $\mathrm{N}(\%)=\mathrm{Kg}$ total $\mathrm{N}$ intake/total DM intake $\times 100$. Feed efficiency was calculated as kg LW gain/kg DM intake. All intake and efficiency determinations are referenced to the animals group as measured unit.

\subsection{Social behaviour}

Calves' interactions were directly observed during twelve hours a day (from 7:00 to 19:00), three days per week in four weeks distributed throughout the experiment (weeks 7, 10, 13 and 16). Six people were trained to perform the behavioural observations, and then, there was one observer for each treatment, in three hours turns. Observers were randomly assigned to each treatment and timetable every day. An interaction was considered when physical contact between two animals was produced. They were registered continuously and the considered activities are described in Table 1.

Table 1. Observed interaction between calves and its respective descriptions.

\begin{tabular}{ll}
\hline Behaviour & $\begin{array}{l}\text { Description } \\
\text { Mounting (M) }\end{array}$ \\
Calf clasping or trying to clasp other calves back with \\
both legs \\
One calf displacing another, with shoulder, side, flank or \\
rump from its standing or lying place. \\
Pushing with chest (P) & One calf pushing with the chest to another calf from its \\
& standing place \\
Head Knocking (H) & One calf knocking another with the head in any part of its \\
Licking a group mate(L) & body \\
Smelling a group mate (S) & Calf licking another at any part of its body \\
Scratching with other (SO) & Calf scratching with the body of another calf
\end{tabular}


Complementary, two new variables were created: positive interactions (PI) by integrating all non-agonistic social behaviour (L, S and SO) and negative interaction ( $\mathrm{NI}$ ) by integrating all agonistic social behaviour ( $\mathrm{M}, \mathrm{D}, \mathrm{P}$, and $\mathrm{H})$.

\subsection{Cortisol and biochemical profile}

Nearby the end of the experiment (day 120) while weighting routine, eight animals were randomly chosen from each group and blood samples were taken from jugular vein puncture. Samples were collected in $7 \mathrm{~mL}$ Vacuum tubes without any anticoagulant and immediately refrigerated and taken to the laboratory, where they were centrifuged at $3000 \mathrm{rpm}$ for $15 \mathrm{~min}$ at $4{ }^{\circ} \mathrm{C}$, as described by (Titto et al., 2010). Serum was then removed and passed to eppendorf tubes $(1.5 \mathrm{~mL})$ for storage at $-400^{\circ} \mathrm{C}$ until the analyses were made. Each sample was divided into three tubes: one for cortisol, one for biochemical profile and the other for backup.

Serum samples were assayed in the Laboratory of Nuclear Techniques, Veterinary Faculty, Montevideo, Uruguay. Cortisol concentrations were determined by a direct solid-phase radioimmunoassay (RIA) using DPC kits (Diagnostic Product Co., Los Angeles, CA, USA). The RIA had a sensitivity of $0.52 \mathrm{ug} / \mathrm{dL}$. All samples were determined in the same assay. The intra-assay coefficients of variation for low (1.28 ug/dL), medium (5.91 ug/dL) and high (17.05 ug/dL) were $10.89 \%, 7.13 \%$ and $2.58 \%$ respectively.

Finally, twelve biochemical parameters were determined by IDEXX VetTest $^{\circledR}$ Chemistry Analizer: Alanine Trasnpherase (ALT), Alkaline Phosphatase (ALKP), Gamma Glutamine Transferase (GGT), Albumine (ALB), Glucose (GLU), Total Protein (TP), Urea (BUN), Total Bilirubine (TBIL), Creatinine Kinase (CK), Calcium (Ca), Phosphates (PHOS), Globuline (GLOB). 


\subsection{Statistical analysis}

All data were analyzed by Statistical Analysis System package (SAS, 2008). Live weight was analyzed using the Mixed Procedure (PROC MIXED) with repeated measures within animals, with initial weight as covariate. The model used was: $y=$ $\mu+T+S+S \times T+$ e; where $y$ is the measurement on animal in the treatment (production system); $\mu$ is general term; $T$ is the effect of weeks since start measures; $S$ the effect of the production system; $S \times T$ the interaction between system and period and $e$ is residual error. LSMEANS with Tukey-Kramer adjustments were used for post-hoc comparisons.

Feed intake data were analyzed using the Mixed Procedure (PROC MIXED) with repeated measures within groups. The model used was: $y=\mu+M+S+S \times M+e$; where $y$ is the measurement on group; $\mu$ is general term; $M$ is the effect of moth since start measures; $S$ the effect of the production system; $S \times M$ the interaction between system and period and $e$ is residual error. LSMEANS with Tukey-Kramer adjustments were used.

Data from the biochemical profile and cortisol were transformed throw $\mathrm{LN}(1+$ value) in order to normalize residual errors, as cited by (Tadich et al., 2005) and variance analyzed by General Linear Model Procedure (PROC GLM).

Interactions between animals were expressed as a count and logarithmic transformation (Ln) were used as cited by (Coutellier et al., 2007) and analyzed using the Mixed Procedure (PROC MIXED) according to (Faerevik et al., 2008), using date as repeated factor and the effect of the period of the day and the week of observation was also assessed.

The model was $\operatorname{Ln}(y)=\mu+T+P+W+P \times T+W \times T+$ e; where $y$ is the response variable; $T$ is the effect of production system (T1, T2 and T3); $P$ the effect of the 
period (corresponding to the four observation turns); $W$ the effect of the week of observation; PxT the interaction between system and period; $W x T$ the interaction between system and week of observation, and $e$ is the residual error. TukeyKramer adjustments were also used for post-hoc comparisons.

\section{Results}

\subsection{Production measures}

Figure 1 shows average live weight evolution for each treatment. Live weight (LW) was similar among the systems for the period studied $(P=0.6842)$ and its evolution was similar for the three treatments as it can be seen in the figure. Average daily gain (ADG) was $0.756 \pm 0.829,0.757 \pm 0.676$ and $0.730 \pm 0.762 \mathrm{~kg} /$ day for T1, T2 and T3 respectively $(p=0.1254)$.

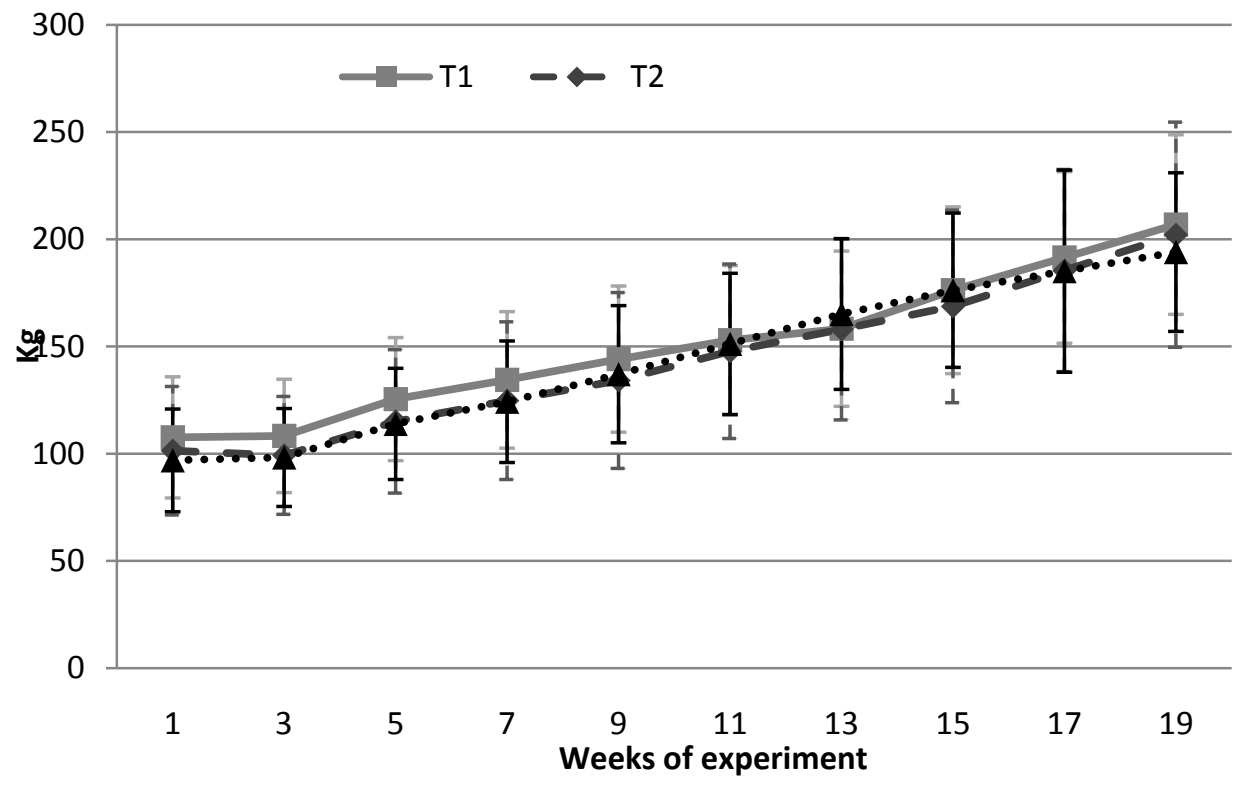

Figure 1 - Live weight evolution (means $\pm s d$ ) from the end of adaptation period to the finish of the experiment for T1, T2 and T3. 
Productive, physiological and social behaviour characterization.

As regards to total dry matter (DM) and total nitrogen (N) intake from the different feeding sources, results are presented in Table 2, and weekly intakes of total DM and $\mathrm{N}$ for each month is presented in Table3.

Table 2- Weekly dry matter (DM) and nitrogen (N) intake for T1, T2 and T3, from the end
of adaptation period to the finish of the experiment (means for the whole experimental
period)

$\overline{a, b, c}$ Means with no common superscript in the column differ significantly $(P<0.05)$

In Table 2 it can be observed that total DM and total $\mathrm{N}$ intake were higher for $\mathrm{T} 2$ and $\mathrm{T} 1$ and $\mathrm{T} 3$ did not present differences in total dry matter intake (DMI). However, N intake (NI) was higher for T3 in relation to T1. Analyzing the components of this DM intake for $\mathrm{T} 1$, the main source was Hay, being significantly higher than T2 and T3. Pasture intake was higher in T3 in comparison with T2, whereas hay intake was substantially higher in $\mathrm{T} 2$.

Despite the variations along the experiment, weekly average DM and $\mathrm{N}$ intake for each month is shown in Table 3. 
Table 3- Weekly dry matter intake (DMI) and nitrogen intake (NI) for each treatment from the end of adaptation period to the finish of the experiment (means for each month)

\begin{tabular}{c|cccccc}
\hline \multicolumn{1}{c}{ Month } & & $\mathbf{1}$ & $\mathbf{2}$ & $\mathbf{3}$ & $\mathbf{4}$ & $\mathbf{5}$ \\
\hline Dry matter & T1 & $629.6^{\mathrm{b}}$ & $802.6^{\mathrm{a}}$ & $874.4^{\mathrm{a}}$ & $877.2^{\mathrm{a}}$ & $859.4^{\mathrm{a}}$ \\
intake & T2 & $975.4^{\mathrm{b}}$ & $990.7^{\mathrm{b}}$ & $919.8^{\mathrm{b}}$ & $1330.1^{\mathrm{a}}$ & $1347.7^{\mathrm{a}}$ \\
(DMI) & T3 & $781.9^{\mathrm{bc}}$ & $819.8^{\mathrm{bc}}$ & $719.9^{\mathrm{c}}$ & $1041.1^{\mathrm{a}}$ & $918.1^{\mathrm{ab}}$ \\
\hline \multirow{2}{*}{ N intake } & T1 & $13.7^{\mathrm{b}}$ & $18.2^{\mathrm{a}}$ & $20.4^{\mathrm{a}}$ & $20.8^{\mathrm{a}}$ & $20.4^{\mathrm{a}}$ \\
(NI) & T2 & $25.3^{\mathrm{b}}$ & $24.7^{\mathrm{b}}$ & $22.8^{\mathrm{b}}$ & $30.5^{\mathrm{a}}$ & $29.6^{\mathrm{a}}$ \\
& T3 & $22.6^{\mathrm{b}}$ & $22.8^{\mathrm{b}}$ & $20.7^{\mathrm{b}}$ & $26.9^{\mathrm{a}}$ & $23.3^{\mathrm{ab}}$ \\
\hline
\end{tabular}

\section{a, b, c Means with no common superscript in the row differ significantly $(P<0.05)$}

As it is seen, DM and $\mathrm{N}$ intake were lower in T1 in the first month and it was increased and stabilized in the rest of the experiment. Moreover, DMI and NI increased in T2 during the last two months. In the case of T3, both DMI and NI were relative stable with a peak in the fourth month.

\subsection{Social behaviour}

Daily average number of interactions for the three treatments is presented in Table 4. In general terms, it is presented that positive interactions did not differ significantly between treatments $(P=0.1496)$ whereas negative interactions (aggressions) resulted higher in T1 $(P<0.0001)$. The same situation may be observed for all separated aggressions, except for $M$ which did not differ significantly within treatments. $H$ was the most frequent aggression in T1 while for T2 and T3 it had similar values to those found for M. Regarding PI, L was the most frequent for all treatments. 
Productive, physiological and social behaviour characterization.

\begin{tabular}{|c|c|c|c|c|}
\hline & T1 & T2 & T3 & $P$ value \\
\hline $\mathrm{H}$ & $5.8 \pm 6.3^{b}$ & $2.7 \pm 2.5^{\mathrm{a}}$ & $1.9 \pm 2.3^{\mathrm{a}}$ & $<.0001$ \\
\hline $\mathbf{P}$ & $3.2 \pm 5.6^{b}$ & $1.1 \pm 1.8^{\mathrm{a}}$ & $0.8 \pm 1.2^{\mathrm{a}}$ & 0.0002 \\
\hline D & $2.2 \pm 4.0^{b}$ & $0.9 \pm 1.5^{\mathrm{a}}$ & $0.8 \pm 1.8^{a}$ & 0.0038 \\
\hline$M$ & $2.2 \pm 2.1$ & $2.7 \pm 3.6$ & $2.5 \pm 2.6$ & 0.9981 \\
\hline $\mathbf{L}$ & $8.7 \pm 7.2$ & $7.2 \pm 8.4$ & $6.7 \pm 6.9$ & 0.1936 \\
\hline so & $1.3 \pm 2.1$ & $1.4 \pm 2.2$ & $0.8 \pm 1.7$ & 0.3138 \\
\hline $\mathbf{S}$ & $3.3 \pm 5.1$ & $2.0 \pm 3.4$ & $2.0 \pm 4.0$ & 0.0937 \\
\hline PI & $13.3 \pm 12.2$ & $10.5 \pm 11.4$ & $9.5 \pm 10.4$ & 0.1496 \\
\hline NI & $13.4 \pm 13.6^{b}$ & $7.4 \pm 5.4^{a}$ & $5.9 \pm 4.6^{\mathrm{a}}$ & 0.0001 \\
\hline
\end{tabular}

${ }^{\mathrm{a}, \mathrm{b}}$ Means with no common superscript differ significantly $(\mathrm{P}<0.05)$

On the other hand, related to the interaction between the moment of the day and treatments, no significant differences were found for any studied behaviour.

Nevertheless, the period of the day itself showed some effect for $\mathrm{M}$ and NI, where higher number of interactions were registered from 7:00 to 10:00 in relation to 10:00 to $13: 00$ period ( $p=0.0118$ and 0.0151 ) and near significance if compared with 13:00 to $16: 00$ ( $p=0.0542$ and 0.0686 respectively). Regarding the effect of the week of observation, daily average interactions for each week are presented in Table 5. As it is observed, significant differences were detected for $M, L$ and PI. $M$ was reduced during the last observation week (16) and L and PI presented the highest values in week 7 as well as a tendency to decrease at the end of the experiment. Nevertheless, the interaction between the week of observation and treatment, did not show any difference. 


\begin{tabular}{|c|c|c|c|c|c|c|c|c|c|}
\hline \multicolumn{10}{|c|}{ S.D.) } \\
\hline Wee & $\mathrm{H}$ & $P$ & $\mathrm{D}$ & $M$ & SO & $L$ & 0 & $\mathrm{NI}$ & $\mathrm{PI}$ \\
\hline 7 & $3.9 \pm 5.5$ & $2.7 \pm 5.9$ & $1.9 \pm 4.4$ & $3.0 \pm 3.7^{b}$ & $1.2 \pm 1.7$ & $11.6 \pm 8.5^{c}$ & $2.9 \pm 3.8$ & $11.5 \pm 13.4$ & $15.7 \pm 12.0^{b}$ \\
\hline 10 & $4.4 \pm 5.4$ & $1.9 \pm 3.4$ & $1.1 \pm 2.0$ & $3.3 \pm 3 .{ }^{b}$ & $1.2 \pm 2.3$ & $7.9 \pm 7.7^{b}$ & $2.8 \pm 4.8$ & $10.7 \pm 10.4$ & $11.9 \pm 12.3^{\mathrm{ab}}$ \\
\hline 132 & $2.7 \pm 2.3$ & $1.1 \pm 1.2$ & $0.5 \pm 1.1$ & $2.5 \pm 2.1^{b}$ & $1.4 \pm 2.5$ & $6.8 \pm 6.9^{\mathrm{ab}}$ & $2.5 \pm 5.1$ & $6.8 \pm 4.2$ & $10.8 \pm 11.9^{\mathrm{ab}}$ \\
\hline 16 & $2.7 \pm 3.5$ & $1.1 \pm 1.9$ & $1.6 \pm 2.2$ & $1.1 \pm 1.4^{\mathrm{a}}$ & $0.9 \pm 1.3$ & $3.8 \pm 4.6^{a}$ & $1.42 .9 \pm$ & $6.5 \pm 5.7$ & $6.2 \pm 7.0^{\mathrm{a}}$ \\
\hline$p$ & 0.1717 & 0.2475 & 0.0570 & 0.0023 & 0.9257 & $<.0001$ & 0.1447 & 0.0523 & 0.0002 \\
\hline
\end{tabular}

${ }^{\mathrm{a}, \mathrm{b}}$ Means with no common superscript differ significantly $(\mathrm{P}<0.05)$

\subsection{Cortisol and biochemical profile}

Average cortisol concentration did not show statistically significant differences $(P=0.7189)$, and means for $T 1, T 2$ and $T 3$ were $2.15 \pm 1.69,2.54 \pm 1.54$ and $2.05 \pm 0.81$ $\mathrm{ug} / \mathrm{dL}$, respectively.

Biochemical profile of blood serum is presented in Table 6. As it is displayed, average values were inside the reference ranges except for CK and GLU, which levels exceeded them in the three treatments.

Even though all values were within the reference range, certain parameters presented statistically significant differences between treatments and animals in T3 reached the highest concentration of BUN as well as the lowest value of ALKP. 
Table 6 - Biochemical profile. Serum concentration of Alanine Trasnpherase (ALT), Alkaline Phosphatase (ALKP), Gamma Glutamine Transferase (GGT), Albumine (ALB), Glucose (GLU), Total Protein (TP), Urea (BUN), Total Bilirubine (TBIL), Creatinine Kinase (CK), Calcium (Ca), Phosphates (PHOS), Globuline (GLOB). Mean \pm S.E.

\begin{tabular}{ccccccc}
\hline & Units & $\begin{array}{c}\text { Reference } \\
\text { values }\end{array}$ & T1 & T2 & T3 & P-value \\
& & & & & \\
\hline ALT & $\mathrm{U} / \mathrm{L}$ & $4-11^{*}$ & $93.4 \pm 6.31$ & $98.1 \pm 7.15$ & $89.8 \pm 6.69$ & $\mathrm{P}=0.6969$ \\
ALKP & $\mathrm{U} / \mathrm{L}$ & $10-149^{* *}$ & $115.6 \pm 9.92 \mathrm{a}$ & $102.8 \pm 11.1 \mathbf{a}$ & $67.9 \pm 11.1 \mathbf{b}$ & $\mathrm{P}=0.0125$ \\
GGT & $\mathrm{U} / \mathrm{L}$ & $0-80^{* *}$ & $15.1 \pm 2.86$ & $19.2 \pm 2.86$ & $13.4 \pm 3.24$ & $\mathrm{P}=0.3859$ \\
ALB & $\mathrm{g} / \mathrm{dL}$ & $2.5-3.6^{* *}$ & $1.17 \pm 0.18$ & $0.89 \pm 0.20$ & $0.78 \pm 0.23$ & $\mathrm{P}=0.3792$ \\
GLU & $\mathrm{mg} / \mathrm{dL}$ & $46.0-93.2^{* *}$ & $127.2 \pm 12.79$ & $157.9 \pm 14.30$ & $144.4 \pm 14.30$ & $\mathrm{P}=0.2919$ \\
TP & $\mathrm{g} / \mathrm{dL}$ & $5.80-8.00^{* *}$ & $8.0 \pm 0.73$ & $7.9 \pm 0.81$ & $8.1 \pm 0.81$ & $\mathrm{P}=0.9802$ \\
BUN & $\mathrm{mg} / \mathrm{dL}$ & $7.0-17.2^{* *}$ & $5.6 \pm 0.66 \mathbf{b}$ & $6.4 \pm 0.74 \mathbf{b}$ & $11.8 \pm 0.86 \mathbf{a}$ & $\mathrm{P}<0.0001$ \\
TBIL & $\mathrm{mg} / \mathrm{dL}$ & $0-0.73^{* *}$ & $0.3 \pm 0.02$ & $0.4 \pm 0.02$ & $0.4 \pm 0.02$ & $\mathrm{P}=0.1352$ \\
CK & $\mathrm{U} / \mathrm{L}$ & $0-110^{* *}$ & $239.0 \pm 116.7$ & $355.7 \pm 116.7$ & $321.0 \pm 132.3$ & $\mathrm{P}=0.7723$ \\
Ca & $\mathrm{mg} / \mathrm{dL}$ & $7.8-10.46^{* *}$ & $11.2 \pm 0.64$ & $11.9 \pm 1.21$ & $10.9 \pm 0.70$ & $\mathrm{P}=0.7765$ \\
PHOS & $\mathrm{mg} / \mathrm{dL}$ & $4.29-7.89^{* *}$ & $7.0 \pm 0.41$ & $6.7 \pm 0.41$ & $6.6 \pm 0.50$ & $\mathrm{P}=0.8511$ \\
GLOB & $\mathrm{g} / \mathrm{dL}$ & $2.70-3.80^{* *}$ & $6.8 \pm 0.54$ & $6.7 \pm 0.69$ & $6.3 \pm 0.69$ & $\mathrm{P}=0.8499$ \\
\hline
\end{tabular}

* (Research Animal Resourses, 2010)

** (Idexx, 2006)

${ }^{a, b}$ Means with no common superscript differ significantly $(P<0.05)$

\section{Discussion}

\subsection{Productive aspects}

Live weight gains in this experiment lie within the range obtained for this strain and age in similar management systems in the region (Fernández-Mayer y Sastre, 2011; Fernández-Mayer y Sastre, 2011; Ruggia et al., 2011). In addition, similar results, $\left(0.733 \mathrm{~kg} \mathrm{day}^{-1}\right)$ were also obtained for Friesian steers in the same range of 
weights, in a mixed system with concentrates and grazing (Keane and Drennan, 2008) and for Danish Holstein steers, grazing in similar pastures with a mix of ryegrass and white clover (Nielsen et al., 2004). In this sense, pasture system did not mean benefits or detriments in live weight as compared to more intensive systems. The same conclusions can be extracted from ADG, as those obtained in this experiment are within the same range in the three treatments. Nevertheless, these ADG are lower than those reported by other authors such as Brosh et al. (1995) and Nielsen et al. (2004), although they worked with wider ranges of live weight and its difficult to know in which point of the growing curve animals are. Nevertheless the feed conversion is one of the most economic traits and in this sense, feed efficiency rate was higher in $\mathrm{T} 2$ do to the higher dry matter intake. One possible factor affecting the feed conversion is the high voluminous feed intake (pasture and hay) that can promote a rapid intestinal transit and a reduction of its metabolic use.

At this point, it is important to remark the importance of $\mathrm{N}$ coming from pasture in total intake in $\mathrm{T} 3$, as the proportion of $\mathrm{N}$ in total $\mathrm{DM}$ that was $2.7 \%$, in contrast with 2.3 and $2.4 \%$ of $\mathrm{T} 1$ and $\mathrm{T} 2$ respectively.

In brief, an excess in voluminous feed sources and inefficient use of food $\mathrm{N}$ for low energy level could not have consequences on growing performance, but it could reduce economical profit and increase $\mathrm{N}$ losses to the environment in the different production systems.

Regarding to the evolution of intake, although there is an increasing tendency by the end of experimental period in $\mathrm{T} 1$ and $\mathrm{T} 2$, as expected according to live weight increase (Igvarsten, 1994), in T3 in the last month tend to be similar to the first three and not showed the same increasing tendency. This is probably caused by a 
decrease of forage availability in the last period, which promoted an increase in the time of grazing, in order to maintain a similar dry matter intake.

\subsection{Cortisol and biochemical profile}

In order to evaluate stress indicators, cortisol levels did not bring any evidence of differences among treatments.

One of the aspects which are commonly related to stress when studying production systems is space allowance since it plays a key role for the social behaviour of cattle (Boe and Faerevik, 2003). Its relationship with stress might be matched with higher blood cortisol concentrations.

In the current study, the surface used in the most restricted treatment (T1) was of $13.1 \mathrm{~m}^{2}$ per animal, which is a higher space allowance in reference to cited works and considering the references established by European Union (1,5 to $1.8 \mathrm{~m}^{2}$ per animal, (European Union Council, 2008). This high space allowance might be the cause for the lack of differences in cortisol levels between treatments, as probably it was not enough to affect animal's stress or cause changes in cortisol levels. In this sense, Fisher et al. (1997b) did not find either any effect on stress parameters when working with space allowances between 2.0 and $3.0 \mathrm{~m}^{2}$. On the contrary, Gupta et al. (2007) found that the lower space allowance, showed higher level of serum cortisol, in an experiment with spaces ranging between 1.2 and 4.2 $\mathrm{m}^{2} /$ animal.

Other aspect which must be taken into account according to its relationship with stress levels is the diet. For example, high-tannin sorghum $(76,5 \%$ of the diet) instead of corn diets helps to reduce cortisol levels (Larraín et al., 2008). This type of sorghum was used in the present study for $\mathrm{T} 1$ and $\mathrm{T} 2$, and no differences were found as compared to T3, which did not include sorghum silage. In this case, 
probably the low proportion of sorghum in total diet (22.6 and $16.3 \%$ for T1 and T2 respectively) did not affect animals, but it is also important to remark that it is difficult to explain differences in stress responses by separated circumstances but in a whole way.

Absolute concentrations of cortisol are very variable throw literature (Romero, 2004) since large differences have been found across species, breeds and individuals, which reflects the contribution of genetic factors and environmental influences (Mormede et al., 2007), but the comparison of the seric cortisol concentration of animals with general similar conditions, are commonly used to measure stress.

In general, animals in the three treatments looked healthy and no animal had to be removed from the experiment due to illness symptoms. This general good status is confirmed by the biochemical profile, which does not show evidence of health problems in any treatment. However, values of certain substances resulted remarkable. That is the case of CK, GLU, ALKP and BUN. Firstly, CK and GLU exceeded reference values for the three treatments whereas ALKP presented statistically significant differences between treatments. In general, CK test is used to indicate stress-induced tissue damage (Hocking et al., 1994; Grounds et al., 2008) or skeletal muscle lesions attributable to trauma or vigorous exercise (Idexx, 2006; Brancaccio et al., 2007) and muscular stress and disorders increase its activity in the blood (Cardinet III, 1997). In the present experiment, the high activity of CK can be explained by the management of the animals before the sample taking, as they had to walk about $1 \mathrm{~km}$ from the yards to the handling facilities where they were weighed. A similar situation was reported by (Ndlovu et al., 2009), with values above references, for grazing steers of three breeds (Angus, 
Bonsmara and Nguni) and they suggested that it was probably caused by a $2 \mathrm{~km}$ walk to the facilities where blood was sampled.

This circumstance could be frequent in handling of cattle in many regions of Uruguay, due to the average surface of the farms, where the infrastructure is centralized in one place. Then, more attention must be paid to handling, even when animals are adapted to walking as occurs in grazing production systems. In this direction, more information is required in order to discriminate between effects and their possible productive and welfare consequences.

Nevertheless, despite CK values were above the reference range for the category, similar CK activities were reported as reference values for young grazing Angoni cattle (Otto et al., 2000) or Nguni animals (Ndlovu, et al., 2009). These results suggest that genetic component could also be affecting the values, and references could be variable for some races or local populations.

On the other hand, glucose concentration largely exceeded reference levels, as well as those reported by other authors (Arai et al., 2006; Swali et al., 2008). Similar high concentration of glucose near $144 \mathrm{mg} / \mathrm{dL}$ was obtained by (Tadich et al., 2005) in Frisian steers after 16 hours of transport. In the present experiment, transportation to handling facilities for weighing and blood sampling, could affect glucose concentration as well as CK (which might be confirmed by a little higher cortisol concentration) although it is difficult to compare the action of moving animals by walking and their transport by track.

Regarding ALKP, its differences are difficult to explain in the present study. High ALKP activity might indicate a rapid skeletal growth or a high bone:muscle ratio (Grunwaldt et al., 2005; Otto et al., 2000) but no arguments can be extracted from this work to support this hypothesis. 
Relative to BUN concentrations, higher values obtained for T3 with may be matched with $\mathrm{N}$ content of the diet. Blood urea concentration is nearly related to protein levels of diet and its energy content (Hammond, 1997), increasing BUN values when crude protein in diet increases, maintaining energy levels (Hammond, 1983). When there is an excess of nitrogen in relation to energy in the rumen, ruminal ammonia concentration increases. Excess of ruminal ammonia enters to the blood torrent through the rumen wall and is transported to the liver where it is detoxified by conversion to urea (Hammond, 1997). Higher levels of BUN concentration reflect a higher ruminal degradability of protein (Hess et al., 2000; Razz and Clavero, 2004).

In this experiment, T3 might have promoted a less efficient use of $\mathrm{N}$ for ruminal microbiota, due to high ruminal degradability of pasture protein, and the absence of an energetic supplement. Although (Hennessy and Williamson, 1990; Hammond, 1997) reported an association between BUN concentration and weight average daily gain, the results of our experiment did not show any difference. This suggests that total $\mathrm{N}$ intake exceeded its possibilities of being metabolized by animals, and more important proportion of $\mathrm{N}$ intake was excreted in a by animals in T3. To the best of our knowledge, these findings mean that not only total DM and energy levels have to be controlled, but also $\mathrm{N}$ concentration in the diet, in order to assure a better conversion efficiency of diet. In this case, pasture becomes an important $\mathrm{N}$ source, and then a strategic supplementation could improve total diet utilization, as concluded by (Lund et al., 2008).

\subsection{Social behaviour}

As it was said, total $\mathrm{NI}$ and all social agonistic behaviours (except $\mathrm{M}$ ) were higher in T1 than in the other two treatments. The increase of the agonistic behaviour as a consequence of a reduction in space allowance is reported by several authors 
Napolitano et al. (2004); Kondo et al. (1989); Gygax et al. (2007), but in the present work it does not seem a valid explanation as there was a high space availability in all treatments as compared to European welfare legislation and published references e.g. Mogensen et al (1997); Gygax et al. (2007); Gupta et al (2007).

Nevertheless, the possibility of interaction between animals in T1 is higher due to a reduced space allowance (as compared to the other treatments), although positive interactions (non-agonistic behaviours) did not differ significantly among treatments. Another possibility for the increase of aggressions in T1 is the competence for resources such as feeders (Faerevik et al., 2007). This hypothesis is reinforced as those behaviours were increased from 7:00 to 10:00 in which grain was supplied in $\mathrm{T} 1$, although we could not detect any interaction between treatment and the period of the day, so the relevance of the competence for feeders in these systems must be accurately studied.

Nevertheless, the experience while doing behavioural observation, indicated that competence increased in the hay expender zone, where animals of T1 spent a long time due to the importance of eating hay in total intake (Table 2). This situation could explain the higher number of $\mathrm{NI}$ in $\mathrm{T} 1$ although the place of aggressions was not registered in this study

Regarding the decreasing trend of $\mathrm{M}, \mathrm{L}$ and total $\mathrm{PI}$ along the day, it is in the line of patterns shown in Chapter 2 where resting behaviours were less likely to be performed at the end of the day.

However, more specific research should be carried out in order to establish the situations which cause each specific behaviour (especially negative interactions), to be able to improve facilities or handling. 


\section{Conclusions}

According to the obtained results, it is not possible to identify differences in productive terms among the three studied systems, although several aspects related to diet utilization must be deeply studied. There are no evidences of increasing stress or health problems in any production system, although it has to be taken in account that permanent confined animals increased agonistic behaviour, which probably reflects some welfare problems. Regarding to human compounds of each system, general animal management must be revised, in order to avoid any physical or physiological disorder caused by some routine handling.

\section{References}

Absmanner, E., Rouha-Mülleder, C., Scharl, T., Leisch, F. and Troxler, J. (2009). Effects of different housing systems on the behaviour of beef bulls--An on-farm assessment on Austrian farms. Applied Animal Behaviour Science 118(1-2), $12-$ 19.

Adams, M. C., Luo, J., Rayward, D., King, S., Gibson, R. and Moghaddam, G. H. (2008). Selection of a novel direct-fed microbial to enhance weight gain in intensively reared calves. Animal Feed Science and Technology 145(1-4), 41-52.

Arai, T., Tanaka, Y., Urabe, S., Kusaba, A., Tazaki, H., Ozawa, T., Kimura, N., Jung, K. K., Waragaya, K., Yuyama, T., Haseba, Y. and Imai, S. (2006). Changes in peripheral leukocytes enzymes activity and plasma metabolite concentrations in growing Holstein calves. Research in Veterinary Science 81(1), 19-23.

Bennett, R., Henson, S., Harper, G., Blaney, R. and Preibisch.K. (2000). Economic evaluation of farm animal welfare policy: baseline study and framework 
development. Final Report The Ministry of Agriculture, Fisheries and Food. The University of Reading, pp. 1-134. Reading.

Blasina, E. (2010). Genes, memes y la competitividad de la carne uruguaya. 6o Congreso de producción, industrialización ycomercialización de carne "Del campo al plato". Montevideo.

Boe, K. E. and Faerevik, G. (2003). Grouping and social preferences in calves, heifers and cows. Applied Animal Behaviour Science 80(3), 175-190.

Bonacic, C., Feber, R. E. and Macdonald, D. W. (2006). Capture of the vicu $\pm a$ (Vicugna vicugna) for sustainable use: Animal welfare implications. Biological Conservation 129(4), 543-550.

Brancaccio, P., Maffulli, N. and Limongelli, F. M. (2007). Creatine kinase monitoring in sport medicine. British Medical Bulletin 81-82(1), 209-230.

Broom, D. M. (2006). Behaviour and welfare in relation to pathology. Applied Animal Behaviour Science 97(1), 73-83.

Brosh, A., Aharoni, Y., Levy, D. and Holzer, Z. (1995). Effect of diet energy concentration and of age of Holstein-Friesian bull calves on growth rate, urea space and fat deposition, and ruminal volume. Journal of Animal Science 73(6), 1666-1673.

Cardinet III, G. H. (1997). Skeletal Muscle Function. Edición: Kaneko, J. Jerry, John, W. Harvey, y Michael, L. Bruss. En: Clinical Biochemistry of Domestic Animals (5). Pag. 407-440. San Diego, Academic Press.

Chorfi, Y., Lanevschi, A., Dupras, R., Girard, V. and Tremblay, A. (2007). Serum biochemical parameters and embryo production during superovulatory treatment in dairy cattle. Research in Veterinary Science 83(3), 318-321. 
Coutellier, L., Arnould, C., Boissy, A., Orgeur, P., Prunier, A., Veissier, I. and Meunier-Salaün, M. C. (2007). Pig's responses to repeated social regrouping and relocation during the growing-finishing period. Applied Animal Behaviour Science 105(1-3), 102-114.

DIEA. (2010). Anuario Estadístico 2010. MGAP. Montevideo.

European Union Council. (2008). Laying down minimum standards for the protection of calves. Council Directive 2008/119/EC of 18 December 2008, DO L 10 de 15.1.2009.

Faerevik, G., Andersen, I. L., Jensen, M. B. and B ${ }^{\circ}$, K. E. (2007). Increased group size reduces conflicts and strengthens the preference for familiar group mates after regrouping of weaned dairy calves (Bos taurus). Applied Animal Behaviour Science 108(3-4), 215-228.

Faerevik, G., Tjentland, K., Lovik, S., Andersen, I. L. and Boe, K. E. (2008). Resting pattern and social behaviour of dairy calves housed in pens with different sized lying areas. Applied Animal Behaviour Science 114(1-2), 54-64.

Fernández-Mayer, A. and Sastre, I. (2011). Ensayo de engorde intensivo pastoril y a corral de terneros machos holando argentino. INTA- EEA Bordenave.

Fisher, A. D., Crowe, M. A., O'Nuallain, E. M., Monaghan, M. L., Larkin, J. A., O'Kiely, P. and Enrright, W. J. (1997a). Effects of cortisol on in vitro interferon-c production, acute phase proteins, growth, and feed intake in a calf castration model. Journal of Animal Science 75, 1041-1047.

Fisher, A. D., Crowe, M. A., O'Kiely, P. and Enright, W. J. (1997b). Growth, behaviour, adrenal and immune responses of finishing beef heifers housed on 
slatted floors at 1.5, 2.0, 2.5 or $3.0 \mathrm{~m} 2$ space allowance. Livestock Production Science 51(1-3), 245-254.

Grounds, M. D., Radley, H. G., Lynch, G. S., Nagaraju, K. and De Luca, A. (2008). Towards developing standard operating procedures for pre-clinical testing in the mdx mouse model of Duchenne muscular dystrophy. Neurobiology of Disease 31(1), 1-19.

Grunwaldt, E., Guevara, J., Estévez, O., Vicente, A., Rousselle, H., Alcuten, N., Aguerregaray, D. and Stasi, C. (2005). Biochemical and Haematological Measurements in Beef Cattle in Mendoza Plain Rangelands (Argentina). Tropical Animal Health and Production 37(6), 527-540.

Gupta, S., Earley, B. and Crowe, M. A. (2007). Pituitary, adrenal, immune and performance responses of mature Holsteináláfriesian bulls housed on slatted floors at various space allowances. The Veterinary Journal 173(3), 594-604.

Gygax, L., Siegwart, R. and Wechsler, B. (2007). Effects of space allowance on the behaviour and cleanliness of finishing bulls kept in pens with fully slatted rubber coated flooring. Applied Animal Behaviour Science 107(1-2), 1-12.

Hammond, A. C. (1983). Effect of dietary protein level, ruminal protein solubility and time after feeding on plasma urea nitrogen and the relationship of plasma urea nitrogen to other ruminal and plasma parameters. J.Anim Sci., 57, pp. 435.

Hammond, A. C. (1997). Update on bun and mun as a guide for protein supplementation in cattle. U.S. Department of Agriculture. Florida. 
Hennessy, D. R. and Williamson, P. J. (1990). Feed intake and liveweight of cattle on subtropical native pasture hays. II. The effect of urea and maize flour, or protected-casein. Australian Journal of Agricultural Research 41, 1179-1185.

Hess, H. D., Lascano, C. E. and Flórez, H. (2000). Blood and Milk Urea Nitrogen as a Tool to Monitor the Protein Nutrition of Cattle under Tropical Conditions. Deutscher Tropentag 2000 in Hohenheim.

Hocking, P. M., Maxwell, M. H. and Mitchell, M. A. (1994). Hematology and Blood Composition at 2 Ambient-Temperatures in Genetically Fat and Lean Adult Broiler Breeder Females Fed Ad-Libitum Or Restricted Throughout Life. British Poultry Science 35(5), 799-807.

Idexx. (2006). Chemistry Description and Guide. Vet Test Manual Operator, pp. H1-H23.

Igvarsten, K.L. (1994) Models of voluntary food intake in cattle. Livestock Production Science, 39 (1), 19-38

Keane, M. G. and Drennan, M. J. (2008). A comparison of Friesian, Aberdeen AngusáláFriesian and Belgian BlueáláFriesian steers finished at pasture or indoors. Livestock Science 115(2-3), 268-278.

Kondo, S., Sekine, J., Okubo, M. and Asahida, Y. (1989). The effect of group size and space allowance on the agonistic and spacing behavior of cattle. Applied Animal Behaviour Science 24(2), 127-135.

Larraín, R. E., Schaefer, D. M., Richards, M. P. and Reed, J. D. (2008). Finishing steers with diets based on corn, high-tannin sorghum or a mix of both: Color and lipid oxidation in beef. Meat Science 79(4), 656-665. 
Lund, P., S egaard, K. and Weisbjerg, M. R. (2008). Effect of strategies regarding concentrate supplementation and day-time grazing on $N$ utilization at both field and dairy cow level. Livestock Science 114(1), 93-107.

Manninen, M., Sankari, S., Jauhiainen, L., Kivinen, T. and Soveri, T. (2007). Insulated, uninsulated and outdoor housing for replacement beef heifers on restricted grass silage-based diet in a cold environment. Livestock Science 107(2-3), 113-125.

Mogensen, L., Krohn, C. C., S'rensen, J. T., Hindhede, J. and Nielsen, L. H. (1997). Association between resting behaviour and live weight gain in dairy heifers housed in pens with different space allowance and floor type. Applied Animal Behaviour Science 55(1-2), 11-19.

Moliterno, E. (1997). Método agronómico. Cangüé. no. 9: 32- 36. Cangüé 9, 32-36.

Mormede, P., Andanson, S., Auperin, B., Beerda, B., Guqmenq, D., Malmkvist, J., Manteca, X., Manteuffel, G., Prunet, P., van Reenen, C. G., Richard, S. and Veissier, I. (2007). Exploration of the hypothalamic-pituitary-adrenal function as a tool to evaluate animal welfare. Physiology \& Behavior 92(3), 317-339.

Napolitano, F., De Rosa, G., Grasso, F., Pacelli, C. and Bordi, A. (2004). Influence of space allowance on the welfare of weaned buffalo (Bubalus bubalis) calves. Livestock Production Science 86(1-3), 117-124.

Ndlovu, T., Chimonyo, M., Okoh, A. I., Muchenje, V., Dzama, K., Dube, S. and Raats, J. G. (2009). A comparison of nutritionally-related blood metabolites among Nguni, Bonsmara and Angus steers raised on sweetveld. The Veterinary Journal 179(2), 273-281. 
Nielsen, B., Thamsborg, S. M., Andersen, H. R. and Kristensen, T. (2004). Herbage intake in Danish Jersey and Danish Holstein steers on perennial ryegrass/white clover pasture. Livestock Production Science 86(1-3), 261-267.

Otto, F., Vilela, F., Harun, M., Taylor, G., Baggasse, P. and Bogin, E. (2000). Biochemical bllod profile on Angoni cattle in Mozambique. Israel Journal of Veterinary Medicine, 55(3).

Palma, R. (2008). Situación del Sector Cárnico. V Congreso de Producción, Industrialización y Comercialización de Carne, "Del Campo al Plato".. Montevideo.

Petherick, J. C. (2005). Animal welfare issues associated with extensive livestock production: The northern Australian beef cattle industry. Applied Animal Behaviour Science 92(3), 211-234.

Purcell, D. and Arave, C. W. (1991). Isolation vs. group rearing in monozygous twin heifers calves. Appl.anim behav.sci. 31, 147-156.

Razz, R. and Clavero, T. (2004). Niveles de urea, fósforo, glucosa e insulina en vacas en ordeño suplementadas con concentradoen un sistema de Panicum maximum y Leucaena leucocephala. Revista Científica, FCV-LUZ XIV(4), 365369.

Realini, C. E., Furnols, M., Guerrero, L., Montossi, F., Campo, M. M., Sa \pm udo, C., Nute, G. R., Alvarez, I., Ca \pm eque, V., Brito, G. and Oliver, M. A. (2009). Effect of finishing diet on consumer acceptability of Uruguayan beef in the European market. Meat Science 81(3), 499-506.

Research Animal Resourses. (2010). Reference Values for Laboratory Animals. http://www.ahc.umn.edu/rar/refvalues.html, University of Minesota. 
Romero, M. L. (2004). Physiological stress in ecology:lessons from biomedical research. TRENDS in Ecology and Evolution, 19(5), pp. 249-255.

Ruggia, A., Montossi, F., Albin, A., Blumetto, O., Brito, G. and Rodríguez, A. (2011). Una oportunidad de incrementar la Productividad Ganadera Nacional: Producción intensiva de carne con animales Holando. Serie Técnica, INIA. Canelones.

SAS. (2008). SAS User's Guide: Statics. SAS Institute Inc..

Swali, A., Cheng, Z., Bourne, N. and Wathes, D. C. (2008). Metabolic traits affecting growth rates of pre-pubertal calves and their relationship with subsequent survival. Domestic Animal Endocrinology 35(3), 300-313.

Tadich, N., Gallo, C., Bustamante, H., Schwerter, M. and van Schaik, G. (2005). Effects of transport and lairage time on some blood constituents of Friesiancross steers in Chile. Livestock Production Science 93(3), 223-233.

Titto, E. A. L., Titto, C. G., Gatto, E. G., Noronha, C. M. S., Mourpo, G. B., Filho, J. C. M. N. and Pereira, A. M. F. (2010). Reactivity of Nellore steers in two feedlot housing systems and its relationship with plasmatic cortisol. Livestock Science 129(1-3), 146-150. 



\section{Capítulo 4}

Caracterización productiva y ambiental de un sistema semi-extensivo de engorde de cerdos en condiciones de sequía en Uruguay 



\section{Resumen}

En Uruguay, coexisten los sistemas de producción de cerdos en confinamiento y los sistemas extensivos con acceso a pasturas. Entre ambos existen diferencias notables en cuanto a costes de producción, bienestar animal e implicaciones medioambientales. Por otro lado, los episodios de sequía provocados por el fenómeno "la Niña" pueden alterar el comportamiento normal de los sistemas pastoriles. En este trabajo se analiza la dinámica de los nutrientes y su posible efecto ambiental en dos ciclos de cebo de cerdos alojados en un sistema de producción al aire libre, denominado "a campo". Los animales contaron con una parcela de encierro permanente donde se localizaba el refugio, comederos y bebederos. Tuvieron acceso a varias parcelas de pastoreo consecutivamente, estando cada parcela accesible durante una semana. La mayor concentración de los nutrientes provenientes de las deyecciones de los animales, se acumulan en el área circundante al refugio y los comederos, siendo menor la concentración de éstos en el área de pastoreo. Existe un leve incremento de nutrientes en las parcelas de pastoreo, entre el momento que los animales ingresan y la clausura del acceso, para luego descender con el transcurso del tiempo. Esta misma tendencia se manifestó en las emisiones de amoníaco. En las condiciones del estudio, las escasas precipitaciones provocaron bajas pérdidas de nutrientes. Se concluye que en el sistema a campo, dada la concentración de nutrientes medida en el área de pastoreo, no existen riesgos ambientales de gran magnitud, aunque sí que puede haber riesgos asociados a la parcela de encierro permanente. Algunos cambios en el diseño, podrían disminuir el riesgo de pérdidas de nutrientes desde el área de encierro permanente. 



\section{Introducción}

La producción porcina en Uruguay ha venido marcada en la última década por una reducción superior al $20 \%$ en las existencias de stock porcino y por una serie de cambios estructurales según la Dirección de Estadísticas Agropecuarias (DIEA, 2007). Estos cambios suponen una tendencia a minimizar las inversiones en infraestructura, favoreciendo el desarrollo de sistemas de cría a campo como indica el Ministerio de Ganadería, Agricultura y Pesca (MGAP et al., 2005).

En Uruguay, un 39\% de los cerdos son producidos en sistemas intensivos, mientras que el $61 \%$ restante se produce en sistemas que utilizan la producción extensiva en la totalidad o en alguna fase del ciclo (DIEA, 2007).

En los sistemas ganaderos pastoriles tradicionales de Uruguay predomina la producción de carne de vacuno basada en pasturas naturales, abarcando el $89 \%$ de la superficie ganadera total (DIEA, 2010). En estos sistemas, la alteración del ciclo de los nutrientes no parece representar un problema ambiental, dado que la incorporación de nutrientes de fuera del sistema es prácticamente inexistente. Sin embargo en otros sistemas de producción como la lechería, se utilizan pasturas sembradas con aporte de concentrados energéticos o fibrosos. Esto supone un doble desafío: en primer lugar, fomentar la capacidad de reciclaje de nutrientes para mejorar la producción de las pasturas, y en segundo la reducción de las pérdidas de nutrientes que pueden producir efectos ambientales adversos (Viñas y Gutiérrez, 2008).

Los sistemas de producción de porcino en campo poseen similitudes con los de la lechería, ya que utilizan el mismo tipo de pasturas y a su vez incorporan piensos. Sin embargo, una parte sustancial de los nutrientes ingeridos por los animales, es excretada en forma de heces y de orina, suponiendo unas pérdidas entre el 50 y el 
60\% en el caso del nitrógeno (Canh et al., 1997; Dourmad et al., 1999). Así pues, estos sistemas semi-extensivos pueden ser causa de afecciones ambientales. En este sentido, la acumulación de nutrientes en los suelos puede ocasionar cambios en la composición vegetal del tapiz y la biomasa microbiana (Inouye y Tilman, 1995) Además, las pérdidas por escurrimiento superficial o lixiviación pueden contribuir a la contaminación de cursos de agua superficiales y aguas subterráneas (Williams et al., 1998). Por otra parte, la acumulación de nutrientes en aguas superficiales en especial nitrógeno $(\mathrm{N})$ y fósforo $(\mathrm{P})$, promueve la eutrofización de los ecosistemas acuáticos, afectando la biodiversidad de los mismos y reduciendo la calidad de agua para su utilización (Carpenter, 2005; Kruk et al., 2009).

En sistemas pastoriles se generan también contaminantes atmosféricos ligados al ciclo del nitrógeno, como consecuencia de la degradación biológica de las deyecciones de los animales (Anderson et al., 2003; Webb et al., 2005a). Entre estos contaminantes cabe destacar la emisión de amoniaco $\left(\mathrm{NH}_{3}\right)$, que puede causar cambios en ecosistemas naturales por procesos de acidificación y eutrofización tras su deposición (Krupa, 2003). También pueden producirse importantes cantidades de óxido nitroso $\left(\mathrm{N}_{2} \mathrm{O}\right)$, que es un gas con un elevado potencial efecto invernadero (IPCC, 2006). Sin embargo, la gestión del estiércol en sistemas pastoriles genera bajas cantidades de metano $\left(\mathrm{CH}_{4}\right)$ dado que en las pasturas normalmente no se dan las condiciones de anaerobiosis necesarias para la producción de este gas (IPCC, 2006).

En lo que respecta a los impactos ambientales de la producción porcina, han sido estudiados más profundamente en sistemas confinados intensivos en Europa y Estados Unidos, donde las exigencias legales de carácter ambiental son cada vez más estrictas (Melse et al., 2009; Milne, 2005). Sin embargo, considerando las 
importantes diferencias entre los sistemas de producción porcina confinados y a campo, es esperable que su impacto potencial sobre el medio ambiente sea también desigual. Más concretamente, existe escasa información sobre el grado de aprovechamiento que los animales hacen de las pasturas, y tampoco se conocen los cambios que estos sistemas originan en los suelos y de forma derivada sobre las emisiones de amoniaco y el escurrimiento superficial o profundo.

Finalmente, debe considerarse que los sistemas productivos de base pastoril, son altamente dependientes de las condiciones climáticas, estando fuertemente influidos tanto en su productividad como en la calidad de las pasturas, principalmente como consecuencia de la disponibilidad de agua y la temperatura. En la producción comercial en Uruguay no se utiliza el riego de pasturas y por tanto la disponibilidad de agua depende directamente de las precipitaciones y de la capacidad de retención de agua por parte del suelo. Si bien la pluviometría media para los meses de primavera supera los $120 \mathrm{~mm}$ mensuales (MET URUGUAY, 2009), el fenómeno meteorológico "El Niño / Southern Oscillation" (ENSO), con sus fases "El Niño" y "La Niña” puede provocar cíclicamente, períodos que se apartan de las condiciones promedio (Ropelewski and Halpert, 1987). El fenómeno de "La Niña" corresponde a un enfriamiento de las capas superficiales en el océano Pacífico, el cual provoca una reducción de las precipitaciones en el Cono sur de Sudamérica. Se extiende en términos promedio de 9 a 12 meses y ocasionalmente hasta 2 años, con un período de recurrencia de entre 2 y 7 años (IRI, 2011). En este sentido, en la región preocupa el desarrollo de éste fenómeno ya que provoca condiciones de precipitaciones por debajo de lo normal, causando períodos de marcado déficit hídrico con relativa frecuencia. Esto puede afectar no 
solo los aspectos productivos, sino también a la dinámica de los nutrientes en el sistema.

Así pues, el presente trabajo tiene como objetivo caracterizar un sistema de producción a campo habitual en Uruguay desde el punto de vista productivo y ambiental, en condiciones de sequía. En particular, se pretende cuantificar los principales impactos esperables de la producción porcina a campo sobre el suelo, el agua $y$ el aire, tomando como referencia el sistema tradicional en confinamiento.

\section{Materiales y métodos}

\subsection{Localización}

Los ensayos se realizaron en la Estación Experimental Las Brujas del Instituto Nacional de Investigación Agropecuaria (INIA) de Uruguay. El período experimental incluyó dos pruebas correspondientes a un cebo de cerdos cada una, y duró desde el 23 de octubre de 2007 al 16 de enero de 2008 (primera prueba) y del 23 de septiembre al 16 de diciembre de 2008 (segunda prueba). Aunque el experimento estaba inicialmente planteado para realizar una prueba en condiciones normales, los resultados de precipitación condicionaron el desarrollo de la pastura. Esto se debió a la coincidencia de estos periodos con la ocurrencia del fenómeno meteorológico de "La Niña", que afectó las primaveras de 2007 y 2008 (INIA-GRAS, 2009)

\subsection{Diseño Experimental}

Se realizaron dos experimentos, uno en 2007 y el otro en 2008. En el primero de ellos se utilizaron 96 cerdos de recría (48 hembras y 48 machos castrados) de la línea genética comercial Delta Híbrido, de 12 semanas de edad y un peso medio 
de $41,7 \pm 5,81 \mathrm{~kg}$ al inicio del experimento. Todos los animales fueron identificados individualmente y distribuidos al azar en 8 grupos de 12 animales (6 hembras y 6 machos castrados por grupo). El ensayo tuvo una duración de 12 semanas. Cuatro grupos fueron asignados a un sistema de engorde tradicional en confinamiento con ventilación natural (T1) y los otros cuatro a un sistema de producción a campo con acceso a pasturas (T2).

El sistema T1 fue utilizado como referencia en cuanto a la utilización alimenticia y crecimiento en un sistema de engorde convencional.

En el segundo experimento (T2B) se realizó una réplica del sistema de campo, utilizando 48 cerdos ( 24 hembras y 24 machos castrados) de 13 semanas de edad con un peso inicial de $50,3 \pm 4,52 \mathrm{~kg}$ y siguiendo el mismo diseño experimental que en $\mathrm{T} 2$ de la primera prueba.

Desde el punto de vista de crecimiento y utilización de nutrientes fueron comparados los tratamientos $\mathrm{T} 1$ y $\mathrm{T} 2$ de la primera experiencia, mientras que para la evolución de los nutrientes en el suelo se realizó la comparación entre años (T2 del primer experimento y $\mathrm{T} 2 \mathrm{~B}$ del segundo).

\subsection{Alojamiento y alimentación}

En el tratamiento $\mathrm{T} 1$, los animales fueron alojados en una nave de ventilación natural, en corrales de $4 \times 3 \mathrm{~m}$, con un $75 \%$ de la superficie de suelo de hormigón y el resto cubierto con slats plásticos. Cada corral poseía dos bebederos tipo chupete y un comedero tipo tolva con 1,2 $\mathrm{m}$ de frente y $100 \mathrm{~kg}$ de capacidad. El purín producido se almacenó en las fosas ubicadas bajo los slats, que eran vaciadas semanalmente en una balsa anaerobia. Antes de cada vaciado se tomó muestra del purín almacenado durante esa semana para su análisis químico y se midió el volumen de purín generado según la altura alcanzada en la fosa. 
En el sistema semiextensivo (T2 y T2B), los animales fueron alojados de forma permanente en una parcela de campo de $20 \times 10 \mathrm{~m}$ cada una (Figura 1). La parcela estaba delimitada por una cerca eléctrica. Dentro de esta parcela los animales disponían de un refugio de madera de $12 \mathrm{~m}^{2}$, tres comederos de hormigón y dos bebederos tipo chupete. Adicionalmente podían acceder en forma libre a través de un corredor a diferentes parcelas de pastoreo, con una superficie de $170 \mathrm{~m}^{2} \mathrm{y}$ consistente en una pradera tradicional de primer año (T2) y segundo año (T2B), con una mezcla forrajera de trébol blanco, trébol rojo y raigrás. Cada semana una nueva parcela era asignada y las parcelas cerradas luego de la semana de pastoreo, no volvieron a ser pastoreadas a lo largo del ciclo de engorde. El orden de asignación fue el mismo para todos los grupos, comenzando por la parcela 1 en la segunda semana de experimento y siguiendo el orden que se indica en la Figura-1.

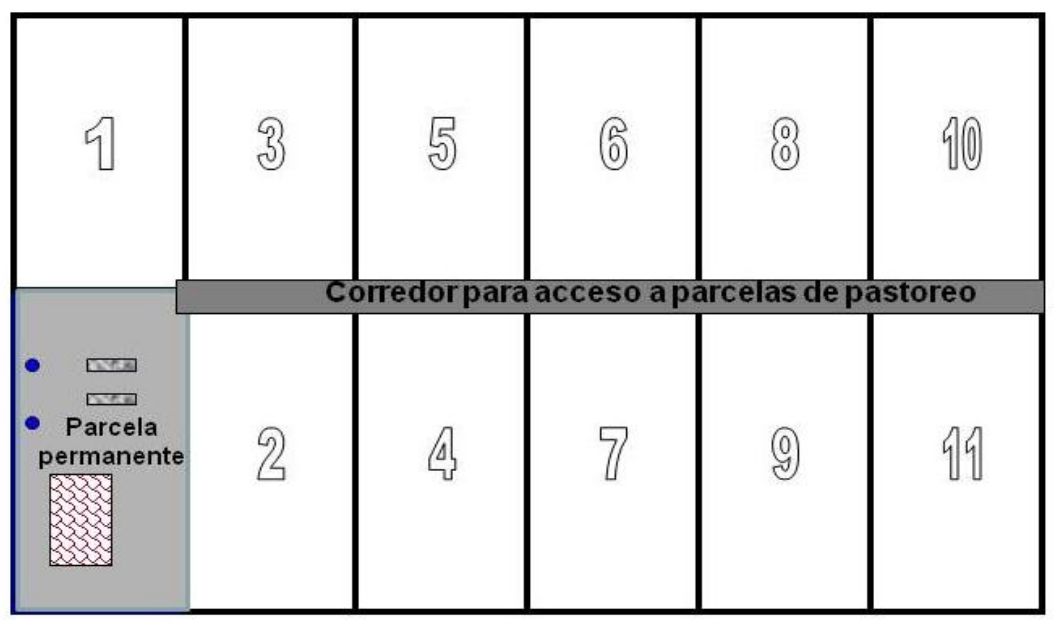

Figura 1- Esquema de distribución y orden de las parcelas de pastoreo de cada grupo en el sistema semiextensivo de engorde de cerdos, para ambos experimentos ( $\mathrm{T} 2$ y $\mathrm{T} 2 \mathrm{~B})$. 
El suelo donde se realizaron los experimentos responde a una textura franco limosa, con un contenido de $16 \%$ arcillas, $20 \%$ arena y $64 \%$ limo. Se determinó una densidad aparente promedio de $1,22 \mathrm{~g} \cdot \mathrm{cm}^{3}$ y una capacidad de retención de agua de $0,44 \mathrm{~m}^{3} / \mathrm{m}^{3}$.

Todos los grupos fueron alimentados con un pienso comercial para cerdos en engorde, a libre disponibilidad. El pienso utilizado en el primer experimento (T1 y T2) tuvo una energía digestible estimada (ED) de $3196 \mathrm{Kcal} / \mathrm{kg}$, mientras que para T2B fue de $3110 \mathrm{Kcal} / \mathrm{kg}$ (Noblet y Pérez, 1993). La composición botánica de la mezcla forrajera en $\mathrm{T} 2$ fue de $37 \pm 10 \%$ trébol, $57 \pm 11 \%$ raigrás y $6 \pm 7 \%$ otros, mientras que para T2B las proporciones de la mezcla fueron de $31 \pm 8 \%$ de trébol. $67 \pm 8 \%$ raigrás y $2,0 \pm 2,0$ otros. Se tomaron muestras de pienso y pastura, a las cuales se les realizó análisis de composición química. En la Tabla 1 se indica la el contenido de piensos y forrajes en proteína bruta (PB), fibra ácido detergente (FAD) y fibra neutro detergente (FND).

Tabla 1: Contenido en proteína bruta (PB), fibra ácido detergente (FAD) y fibra neutro detergente (FND) de piensos y forrajes utilizados, expresada como \% sobre materia seca.

\begin{tabular}{ccccc}
\hline & \multicolumn{2}{c}{ Primera prueba (T1 y T2) } & \multicolumn{2}{c}{ Segunda prueba (T2B) } \\
& Concentrado & Pradera & Concentrado & Pradera \\
\hline PB & 14,9 & 8,3 & 15,2 & 8,0 \\
FAD & 13,2 & 46,9 & 13,0 & 51,1 \\
FND & 34 & 69,4 & 32,5 & 71,0 \\
\hline
\end{tabular}

\subsection{Medidas de producción}

Se registró el peso vivo de forma individual y el consumo de pienso y agua para cada grupo, cada semana, desde la entrada de los animales hasta el final del 
experimento. Para T2 y T2B, el consumo de pastura fue estimado por diferencia entre la disponibilidad al inicio y al final del período de pastoreo, por el método estándar (Moliterno, 1986).

\subsection{Registros ambientales}

Al inicio del primer experimento se tomó una muestra general de suelo para determinar sus características físicas mediante procedimientos estándar: textura (USDA, 1972), densidad aparente (SSSA, 1986a) y capacidad de retención de agua (SSSA, 1986b). En T2 para el primer ensayo y T2B para el segundo, se determinó la evolución del estado del suelo como consecuencia del pastoreo. Para ello, en el encierro permanente se tomaron muestras de suelo cada 15 días durante todo el experimento, a $25 \mathrm{~cm}$ de profundidad, con 9 puntos de muestreo en cada caso. De igual forma, en cada parcela de pastoreo se tomaron muestras de suelo en cuatro momentos: antes del pastoreo (entrada), a la salida de los animales (cierre de la parcela), a los 15 días y a los 30 días después del cierre de la parcela. Para completar la información obtenida, en T2B se decidió agregar dos muestreos adicionales, a los 45 y a los 60 días después del cierre. Las muestras fueron analizadas en laboratorio determinándose el nitrógeno total $(\mathrm{N})$, nitratos $\left(\mathrm{NO}_{3}\right)$, nitrógeno amoniacal $\left(\mathrm{NH}_{4}^{+}\right)$, fósforo total por método Bray I $(\mathrm{P})$, potencial de mineralización de nitrógeno (PMN), calcio (Ca), potasio (K), sodio ( $\mathrm{Na}$ ) acidez titulable (AT), capacidad de intercambio catiónico (CIC), bases totales (BT) y porcentaje de saturación de bases (PSB).

Para analizar el escurrimiento superficial de agua ante la ocurrencia de precipitaciones, en tres de los cuatro grupos se instalaron sistemas para la medición de escurrimiento superficial, con la metodología descrita por (Franklin et al., 2001). Este sistema consta de una microcuenca cerrada y un sistema de recogida para el muestreo de agua, medición de volumen y posterior análisis 
químico. El sistema se instaló dentro de la tercera parcela de pastoreo de cada grupo, una vez se produjo el cierre de la misma. Además se montó un sistema complementario para medir el escurrimiento superficial de agua de un tercio de la parcela de encierro permanente. Para ello se realizó la canalización de los bordes de la superficie del área a evaluar y en la parte más baja se construyó un colector con un depósito enterrado con capacidad para 1,2 $\mathrm{m}^{3}$. Posteriormente a cada evento de lluvia se midió el volumen y se tomaron muestras para enviar a laboratorio, donde se determinó concentración de $\mathrm{N}$ y P.

Para la determinación de emisiones de amoníaco se utilizaron cámaras estáticas de polimetil metacrilato (PMMA), de dimensiones $60 \times 40 \times 40 \mathrm{~cm}$ (largo x ancho x alto). Dentro de la cámara se instaló una bomba de aire, marca Shark modelo RS610 (caudal nominal $140 \mathrm{~L} \mathrm{hora}^{-1}$ ), en cuya salida se colocó un tubo de silicona, con una piedra porosa en el extremo que burbujeaba dentro de un recipiente con una solución de ácido bórico $0.2 \mathrm{M}$. Cada muestra se tomó tras 24 horas de exposición, en una posición fija dentro de cada parcela. El amoniaco retenido en cada caso se determinó en laboratorio mediante titulación con ácido sulfúrico, obteniéndose posteriormente el ratio de emisión por unidad de superficie.

\subsection{Análisis estadísticos}

Para el tratamiento de datos se utilizó el paquete estadístico SAS 9.2 (SAS, 2008). Los datos de ganancia de consumo de pienso, consumo de pastura y eficiencia de conversión, fueron analizados mediante un análisis de varianza con el procedimiento GLM, para comprobar diferencias entre tratamientos y grupos utilizando el siguiente modelo, donde $Y_{i j k}$ es la variable independiente, $\mu$ es la media poblacional, $T_{i}$ el efecto del tratamiento (T1 y T2), Gj es el efecto del grupo $\mathrm{y} \varepsilon_{i j k}$ el error residual. 
$Y_{i j k}=\mu+T_{i}+G_{j}+\varepsilon_{i j k}$

La comparación de concentración de nutrientes en el suelo, entre la situación previa al pastoreo y el momento de cierre de las parcelas, fue analizada mediante un análisis de varianza con el procedimiento GLM con el modelo siguiente, donde $Y_{i j k}$ es la concentración del nutriente, $T_{i}$ el efecto del tratamiento (T2 y T2b), Mj es el efecto del momento (antes o después del pastoreo), $G_{m}$ el efecto del grupo y $\varepsilon_{i j k}$ el error residual.

$Y_{i j k}=\mu+T_{i}+M_{j}+G_{k}+\varepsilon_{i j k}$

En cuanto a la evolución de la concentración de nutrientes en el suelo de las parcelas, se realizaron regresiones con el procedimiento REG utilizando el modelo siguiente, donde, " $\mathrm{y}$ " es la concentración del nutriente en el suelo, " $\mathrm{A}$ " el año expresado como variable cualitativa ( $\mathrm{A}=0$ para $\mathrm{T} 2$ y $\mathrm{A}=1$ para $\mathrm{T} 2 \mathrm{~B}$ ) y " $\mathrm{t}$ " los días trascurridos desde el cierre.

$y=\beta_{0}+\beta_{1} A+\left(\beta_{2}+\beta_{3} A\right) t+\varepsilon$,

Finalmente, la evolución de las emisiones de amoníaco desde el cierre de las parcelas de pastoreo se analizó mediante el procedimiento REG siguiendo el siguiente modelo, donde $\mathrm{E}_{\mathrm{NH} 3}$ es la cantidad de $\mathrm{NH}_{3}$ emitido y " $\mathrm{t}$ " el tiempo (en días) trascurrido desde el cierre. $\mathrm{E}_{\mathrm{NH} 3}=\beta_{0}+\beta_{1} \cdot(1 / \mathrm{t})+\varepsilon$

\section{Resultados}

\subsection{Crecimiento, consumo y eficiencia de utilización alimenticia}

Para T1 y T2, los valores medios obtenidos para la ganancia de peso vivo, el consumo de pienso y pastura y el índice de conversión alimenticia en el total del ciclo, así como la ingesta promedio de N y P pueden observarse en la Tabla 2. 
Tabla 2- Consumos medios de pienso, pastura, nitrógeno y fósforo, ganancia media de peso vivo, y eficiencia de conversión alimenticia de cerdos en

\begin{tabular}{lccc}
\hline & T1 & T2 & $\boldsymbol{p}$ \\
\hline Ganancia media de peso para todo el engorde & 67,8 & 61,5 & $* * *$ \\
Consumo medio de pienso por grupo (kg MS) & 3097,4 & 3173,8 & NS \\
Consumo medio de pastura por grupo (kg MS) & -- & 259,5 & -- \\
Consumo medio de alimento total por grupo & 3097,4 & 3433,2 & $*$ \\
Conversión alimenticia (kg MS pienso /kg & 3,95 & 4,30 & $* * *$ \\
Consumo medio de nitrógeno proveniente de & -- & 5,4 & -- \\
Consumo medio de fósforo proveniente de la & -- & 0,8 & -- \\
Consumo medio de nitrógeno proveniente del & 79,3 & 81,3 & NS \\
Consumo medio de fósforo proveniente de la & 18,6 & 19,0 & NS \\
Consumo medio de nitrógeno proveniente de & 79,3 & 87,2 & NS \\
Consumo medio de fósforo proveniente de & 185,8 & 198,4 & NS \\
\hline
\end{tabular}

No se observaron diferencias significativas en los consumos de $\mathrm{MS}, \mathrm{N}$ o $\mathrm{P}$ entre ambos tratamientos $(p>0,05)$. No obstante la ganancia de peso y la eficiencia de conversión alimenticia fueron mejores en los animales del tratamiento T1 $(p<0,001)$. En todos los casos, el efecto grupo no fue significativo $(p>0,05)$.

\subsection{Registros ambientales}

\subsubsection{Purines producidos en sistema confinado}

Los grupos alojados en confinamiento produjeron en promedio, durante todo el experimento, $5.788 \pm 729$ L de purín por grupo (media \pm desviación estándar), con una excreción total de $2.666 \pm 116$ g de $\mathrm{P}$ y $18.970 \pm 1.252$ g de N por grupo. La evolución del purín producido por animal y por semana, así como las cantidades de nutrientes ( $\mathrm{N}$ y $\mathrm{P}$ ) en el purín recogido, se indican en la Figura 2. 


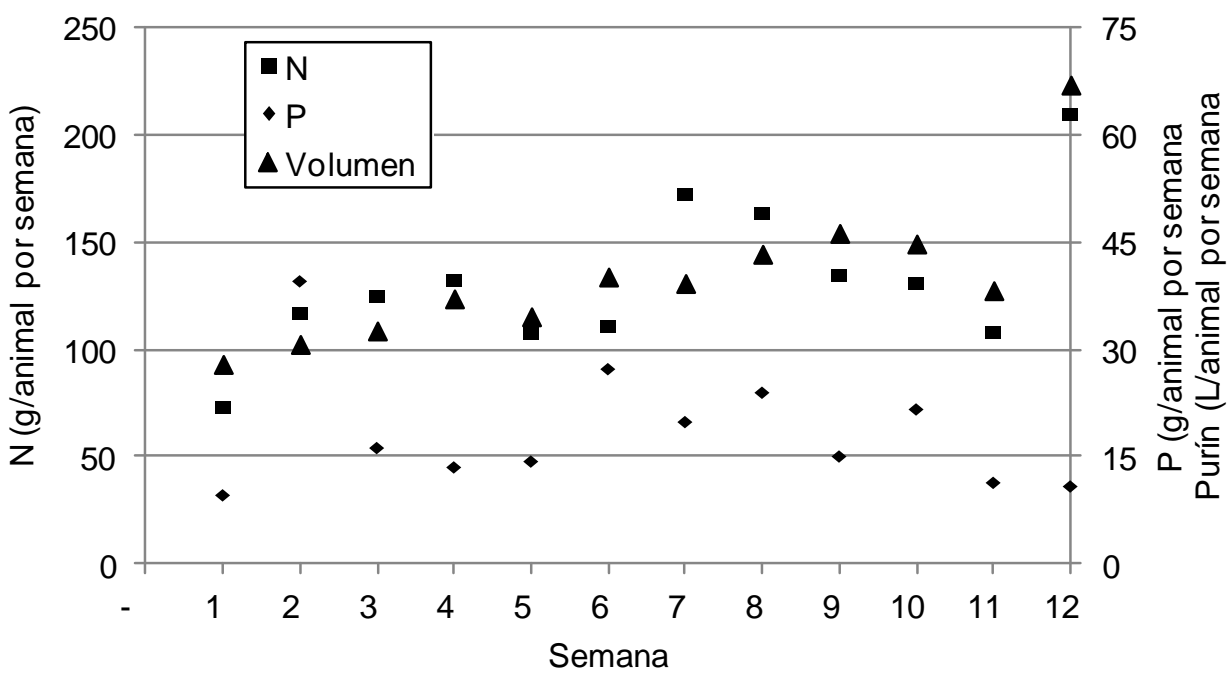

Figura 2 - Producción semanal de purín y evolución de las cantidades de N y P presentes en el purín producido en el sistema intensivo de engorde (T1).

\subsubsection{Sistema a campo: evolución de las propiedades del suelo}

Las concentraciones medias de nutrientes en las parcelas de pastoreo, antes de la entrada de los animales y después del cierre se presentan en la Tabla 3.

Tabla 3 - Concentración de nutrientes en el suelo de las parcelas del sistema semi-extensivo, antes del pastoreo y una vez producido el cierre una semana después.

\begin{tabular}{|c|c|c|c|c|c|c|c|c|c|c|c|}
\hline $\begin{array}{l}\text { Año } \\
\text { de } \\
\text { prue } \\
\text { ba }\end{array}$ & $\begin{array}{c}\text { Mome } \\
\text { nto }\end{array}$ & $\begin{array}{l}\mathrm{N} \\
\%\end{array}$ & $\begin{array}{l}\mathrm{NO}_{3} \\
\mathrm{mg} / \\
\mathrm{Kg}\end{array}$ & $\begin{array}{c}\mathrm{NH}_{4}^{+} \\
\mathrm{mg} / \\
\mathrm{Kg}\end{array}$ & $\begin{array}{c}\mathrm{PMN} \\
\mathrm{mg} / \\
\mathrm{Kg}\end{array}$ & $\begin{array}{l}\mathrm{P} \\
\mu \mathrm{g} \\
/ \mathrm{g}\end{array}$ & $\begin{array}{c}\mathrm{K} \\
\mathrm{meq} / 10 \\
0 \mathrm{~g}\end{array}$ & $\begin{array}{c}\mathrm{Mg} \\
\mathrm{meq} / 10 \\
0 \mathrm{~g}\end{array}$ & $\begin{array}{c}\mathrm{Ca} \\
\mathrm{meq} / 10 \\
0 \mathrm{~g}\end{array}$ & $\begin{array}{c}\mathrm{Na} \\
\mathrm{meq} / 10 \\
\mathrm{Og}\end{array}$ & $\begin{array}{c}\text { Base } \\
s \\
\text { total }\end{array}$ \\
\hline 200 & antes & 0,2 & 16 & 14 & 70,0 & 29 & 0,85 & 4,98 & 12,9 & 0,40 & 19,0 \\
\hline 7 & cierre & 0,2 & 19 & 22 & 106, & 27 & 0,85 & 5,10 & 12,4 & 0,37 & 18,6 \\
\hline$p$ & & $* *$ & NS & $*$ & $* * *$ & NS & NS & NS & NS & NS & NS \\
\hline 200 & antes & 0,2 & 19 & 20 & 95,5 & 29 & 0,89 & 5,58 & 13,29 & 0,39 & 20,1 \\
\hline 8 & cierre & 0,2 & 29 & 34 & 76,8 & 30 & 0,91 & 5,78 & 13,29 & 0,41 & 20,3 \\
\hline$p$ & & NS & $* *$ & $*$ & NS & NS & NS & NS & NS & NS & NS \\
\hline
\end{tabular}


No se encontraron diferencias significativas en la concentración de las bases y fósforo para ambos momentos $(p>0,05)$. Por el contrario, la concentración de amoníaco se incrementó significativamente después del cierre en ambas pruebas $(p<0,05)$. En cambio, el contenido en nitrógeno total y nitratos tuvieron un comportamiento diferente en cada año: mientas que el contenido en $\mathrm{N}$ aumentó significativamente $(p<0,001)$ en la primera prueba $(T 2)$, éste se mantuvo estable en la segunda (T2B). La situación inversa se constató para los nitratos, incrementándose significativamente $(p<0,01)$ después del cierre en T2B pero no en $\mathrm{T} 2$.

Las regresiones realizadas para determinar el efecto del tiempo transcurrido tras el cierre de las parcelas de pastoreo sobre la concentración de nutrientes dieron como resultado unas pendientes muy bajas (Tabla 4), indicando una baja dependencia del tiempo transcurrido tras el cierre.

Tabla 4 - Parámetros de las regresiones de la concentración de nutrientes en el suelo, en función del los días transcurridos desde el cierre de las parcelas de pastoreo (t), utilizando año (A) como variable dummy.

\begin{tabular}{cccccccccccc}
\hline Nutrien & Unidad & $\beta_{0}$ & $\mathrm{p}$ & $\beta_{1}$ & $\mathrm{p}$ & $\beta_{2}$ & $\mathrm{p}$ & $\beta_{3}$ & $\mathrm{p}$ & $\mathrm{R}^{2}$ & $\mathrm{P}$ \\
\hline $\mathbf{N}$ & $\mathbf{\%}$ & $\mathbf{0 , 2 8 2}$ & $* *$ & - & $* *$ & - & $*$ & $\mathbf{0 , 0 0}$ & $*$ & $\mathbf{0 , 0 6}$ & $* * *$ \\
$\mathrm{NO}_{3}$ & $\mu \mathrm{g} / \mathrm{g}$ & 18,71 & $* *$ & 5,31 & $\mathrm{NS}$ & 0,18 & $\mathrm{~N}$ & 0,38 & $\mathrm{~N}$ & 0,19 & $* * *$ \\
$\mathrm{NH}_{4}$ & $\mu \mathrm{g} / \mathrm{g}$ & 22,07 & $* *$ & 10,6 & $\mathrm{NS}$ & - & $\mathrm{N}$ & 0,55 & $\mathrm{~N}$ & 0,15 & $* * *$ \\
$\mathrm{PMN}$ & $\mathrm{mg} / \mathrm{Kg}$ & 113,4 & $* *$ & - & $\mathrm{NS}$ & - & $\mathrm{N}$ & 3,06 & $\mathrm{~N}$ & 0,00 & $\mathrm{NS}$ \\
$\mathrm{P}$ & $\mu \mathrm{g} / \mathrm{g}$ & 27,52 & $* *$ & 1,36 & $\mathrm{NS}$ & - & $\mathrm{N}$ & 0,48 & $*$ & 0,17 & $* * *$ \\
$\mathrm{~K}$ & $\mathrm{meq} / 10$ & 0,844 & $* *$ & 0,03 & $\mathrm{NS}$ & - & $\mathrm{N}$ & 0,00 & $*$ & 0,16 & $* * *$ \\
$\mathrm{Na}$ & $\mathrm{meq} / 10$ & 0,364 & $* *$ & 0,00 & $\mathrm{NS}$ & 0,00 & $\mathrm{~N}$ & 0,00 & $\mathrm{~N}$ & 0,09 & $* * *$ \\
$\mathrm{Mg}$ & $\mathrm{meq} / 10$ & 5,072 & $* *$ & 0,79 & $* *$ & 0,00 & $\mathrm{~N}$ & - & $\mathrm{N}$ & 0,04 & $*$ \\
$\mathrm{Ca}$ & $\mathrm{meq} / 10$ & 12,43 & $* *$ & 1,27 & $* *$ & - & $\mathrm{N}$ & 0,00 & $\mathrm{~N}$ & 0,07 & $* * *$ \\
Bases & $\mathrm{meq} / 10$ & 18,71 & $* *$ & 2,10 & $* *$ & - & $\mathrm{N}$ & - & $\mathrm{N}$ & 0,06 & $* * *$ \\
\hline
\end{tabular}


Los nitratos y amoníaco, presentaron una tendencia creciente a lo largo del tiempo para la segunda prueba, pero por el contrario no se encontraron variaciones para 2007 dentro del lapso estudiado. En todos los casos se constató una variabilidad muy alta de los valores registrados en las determinaciones de nutrientes en el suelo.

En el caso del P se observa una tendencia diferente en cada año, mientras que en T2 las concentraciones descienden, en T2B tienden a incrementarse con el transcurso de los días.En el caso de las parcelas de encierro permanente, se observa una situación similar en cuanto a las variaciones de las bases en el suelo, siendo estas con pendientes positivas, pero muy próximas a 0 (Tabla 5). En el caso de de $\mathrm{NO}_{3}$ y $\mathrm{NH}_{4}$, existe una clara tendencia ascendente a lo largo del período de engorde para ambos años.

Tabla 5 - Parámetros de las regresiones de la concentración de nutrientes en el suelo, en función del los días transcurridos desde el cierre $(t)$ de las parcelas de encierro permanente, utilizando año $(A)$ como variable dummy.

\begin{tabular}{cccccccccccc}
\hline Nutrien & Unidade & $\beta_{0}$ & $\mathrm{p}$ & $\beta_{1}$ & $\mathrm{p}$ & $\beta_{2}$ & $\mathrm{p}$ & $\beta_{3}$ & $\mathrm{p}$ & $\mathrm{R}^{2}$ & $\mathrm{p}$ \\
\hline $\mathrm{N}$ & $\%$ & 0,247 & $* *$ & 0,034 & $\mathrm{NS}$ & 0,00 & $* *$ & - & $* *$ & 0,420 & $* *$ \\
$\mathrm{NO}_{3}$ & $\mu \mathrm{g} / \mathrm{g}$ & - & $\mathrm{NS}$ & 102,03 & $* *$ & 1,55 & $* *$ & - & $* *$ & 0,442 & $* *$ \\
$\mathrm{NH}_{4}$ & $\mu \mathrm{g} / \mathrm{g}$ & 4,135 & $\mathrm{NS}$ & 0,583 & $\mathrm{NS}$ & 1,65 & $* *$ & - & $* *$ & 0,422 & $* *$ \\
$\mathrm{PMN}$ & $\mathrm{mg} / \mathrm{Kg}$ & 47,37 & $\mathrm{NS}$ & - & $\mathrm{NS}$ & 2,53 & $\mathrm{NS}$ & - & $\mathrm{NS}$ & 0,105 & $\mathrm{NS}$ \\
$\mathrm{P}$ & $\mu \mathrm{g} / \mathrm{g}$ & 26,25 & $*$ & 37,714 & $* *$ & 0,43 & $\mathrm{NS}$ & 0,49 & $\mathrm{NS}$ & 0,146 & $*$ \\
$\mathrm{~K}$ & $\mathrm{meq} / 10$ & 0,659 & $*$ & 0,813 & $*$ & 0,01 & $* *$ & - & $*$ & 0,150 & $*$ \\
$\mathrm{Na}$ & $\mathrm{meq} / 10$ & 0,337 & $* *$ & 0,227 & $* *$ & 0,00 & $* *$ & - & $*$ & 0,362 & $* *$ \\
$\mathrm{Mg}$ & $\mathrm{meq} / 10$ & 4,543 & $* *$ & 1,883 & $* *$ & 0,01 & $*$ & - & $*$ & 0,191 & $* *$ \\
$\mathrm{Ca}$ & $\mathrm{meq} / 10$ & 13,60 & $* *$ & 0,437 & $\mathrm{NS}$ & - & $\mathrm{NS}$ & - & $\mathrm{NS}$ & 0,024 & $\mathrm{NS}$ \\
Bases & $\mathrm{meq} / 10$ & 19,13 & $* *$ & 3,360 & $\mathrm{NS}$ & 0,03 & $\mathrm{NS}$ & - & $\mathrm{NS}$ & 0,061 & $\mathrm{NS}$ \\
\hline
\end{tabular}




\subsubsection{Sistema a campo: escorrentía superficial y profunda}

En los últimos 15 días del ciclo de engorde en la primera prueba (T2), se produjeron cuatro eventos de lluvia, de 19,$4 ; 12,2 ; 24,6$ y $33,8 \mathrm{~L} / \mathrm{m}^{2}$ respectivamente. Estas precipitaciones provocaron pérdidas de nutrientes del suelo en las parcelas de encierro, que se reflejaron en una reducción significativa de los valores de nutriente registrados con excepción de $\mathrm{Mg}$ y $\mathrm{Na}$, entre las muestras tomadas los días 79 y 94 del ciclo, como puede observarse en la Tabla 6.

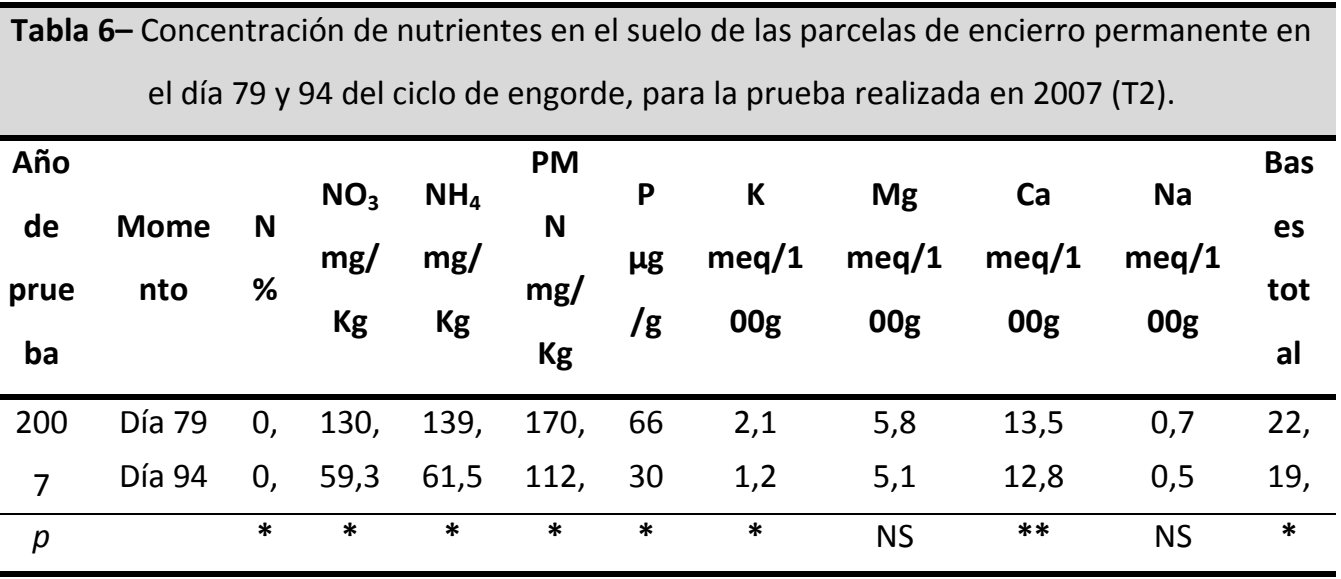

Las muestras recogidas en los sistemas de medición de escurrimiento en los encierros y el sistema de bandejas de escurrimiento de las parcelas de pastoreo, se encuentran resumidos en la Tabla 7.

En la segunda prueba (T2B) no se produjeron precipitaciones de cuantía suficiente como para registrar escorrentía superficial o infiltración profunda. 


\begin{tabular}{|c|c|c|c|c|c|}
\hline $\begin{array}{c}\text { Día del } \\
\text { ciclo }\end{array}$ & $\begin{array}{c}\text { Precipitación } \\
\qquad / \mathrm{m}^{2}\end{array}$ & muestra & $\begin{array}{c}\text { Cantidad de } \\
\text { escorrentía } \\
\text { L / m }{ }^{2}\end{array}$ & $\begin{array}{c}\text { Escorrentía } \\
\text { de } P \\
\mathrm{mg} / \mathrm{m}^{2}\end{array}$ & $\begin{array}{c}\text { Escorrentía } \\
\text { de } \mathrm{N} \\
\mathrm{mg} / \mathrm{m}^{2}\end{array}$ \\
\hline \multirow{2}{*}{68} & \multirow{2}{*}{19,4} & Parcelas & 1,4 & 2,2 & 240,9 \\
\hline & & Encierro & 0,4 & 1,2 & 128,3 \\
\hline \multirow{2}{*}{72} & \multirow{2}{*}{12,2} & Parcelas & 0,3 & 0,3 & 46,1 \\
\hline & & Encierro & 1,0 & 1,2 & 157,2 \\
\hline \multirow{2}{*}{73} & \multirow{2}{*}{24,6} & Parcelas & 1,0 & 0,9 & 108,4 \\
\hline & & Encierro & 1,4 & 2,1 & 305,4 \\
\hline \multirow{2}{*}{81} & \multirow{2}{*}{33,8} & Parcelas & 1,0 & 1,7 & 51,7 \\
\hline & & Encierro & 3,7 & 33,6 & 408,9 \\
\hline
\end{tabular}

\subsubsection{Sistema a campo: emisiones de $\mathrm{NH}_{3}$}

Las emisiones de amoníaco medidas para las parcelas de pastoreo muestran un aumento significativo $(p<0,001)$ entre la situación previa al pastoreo $(8,8 \pm 5,3 \mathrm{mg}$ $\mathrm{NH}_{3} / \mathrm{m}^{2} /$ día) y tras el cierre $\left(79,6 \pm 4,6 \mathrm{mg} \mathrm{NH} / \mathrm{m}^{2} /\right.$ día). La evolución de las emisiones después del cierre fue desigual en los dos ciclos estudiados, según se muestra en la Figura 3. En el primer ciclo (T2A), la evolución de las emisiones se ajustó al modelo propuesto, según la ecuación:

$y=104,2+91,7(1 / t) \quad p=0,0014 ; R^{2}=0,997$ 


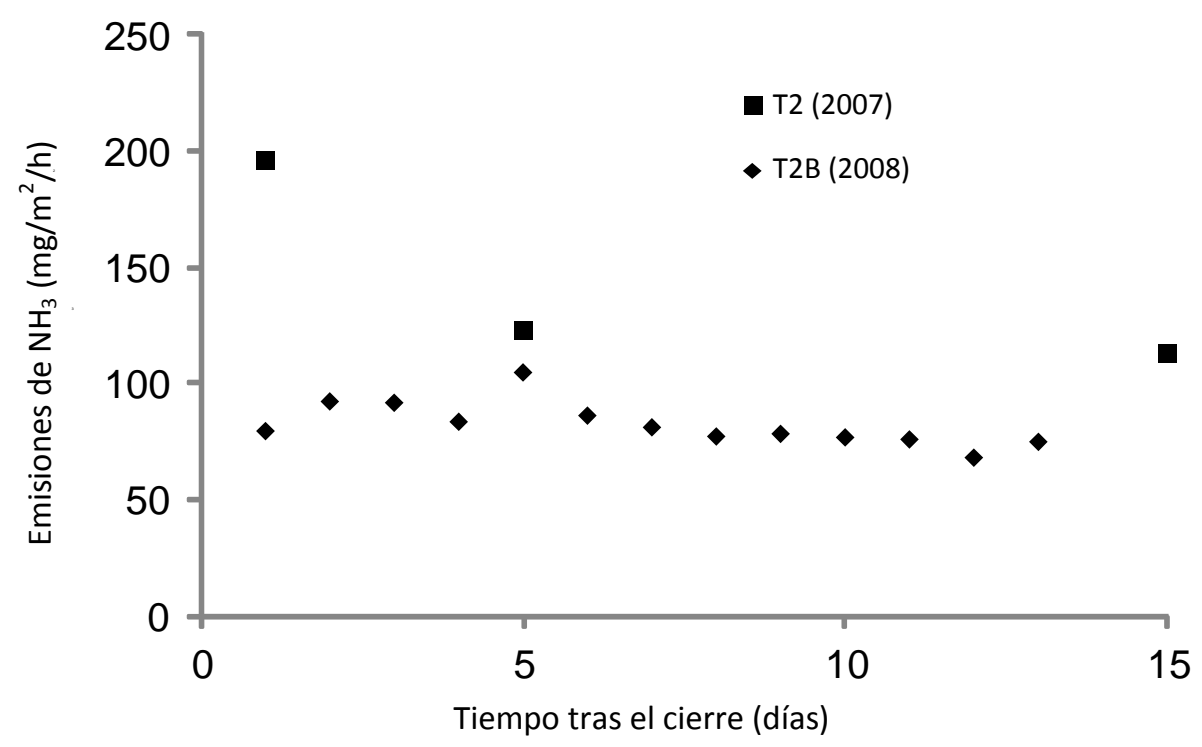

Figura 3- Evolución de las la emisión de $\mathrm{NH}_{3}$ tras el cierre de las parcelas de pastoreo, en el sistema semiextensivo de engorde de cerdos en ambos experimentos ( $\mathrm{T} 2$ y $\mathrm{T} 2 \mathrm{~B}$ ).

Atendiendo a resultados en los días muestreados $(1,5,15$ y 30 días tras el cierre) se consideró conveniente realizar mediciones más frecuentes en el segundo ciclo, con el objetivo de caracterizar con más detalle esta variación de las emisiones en las dos semanas tras el cierre del acceso a la parcela. Sin embargo, en el segundo ciclo la evolución de las emisiones fue completamente distinta, tal como se observa en la Figura 3. Así, el modelo de emisión propuesto resultó no significativo $(p>0,05)$, de forma que no pudo confirmarse la pauta de evolución de emisiones identificada el año anterior. Las emisiones de las parcelas de encierro desde la salida de los animales (fin del ciclo) hasta los 52 días posteriores, mostraron variaciones erráticas entre días, con una media de 75,7 $\pm 23,8 \mathrm{mg}$ $\mathrm{NH}_{3} / \mathrm{m}^{2} /$ día. 


\section{Discusión}

\subsection{Consumo y eficiencia de utilización alimenticia}

El pienso fue el componente principal en la alimentación de los animales en ambos casos (T1 y T2) y su consumo no difirió entre los animales confinados y los que tenían acceso a pastura. El consumo de pastura, tuvo poca importancia en el total de MS ingerida y no llegó a provocar una reducción en la ingesta de pienso como la obtenida por Bauzá et al. (2005). En este sentido, se debe considerar que la libre disponibilidad de pienso puede influir en el comportamiento alimentario de los cerdos. Así, Barloco (2007) obtuvo un aprovechamiento de la pastura muy superior al de este estudio en condiciones de pienso restringido, alcanzando así un compromiso económico favorable.

La baja calidad del forraje es también un elemento a considerar en la reducción del consumo, pudiendo ser responsable de la baja importancia del mismo en el total de la MS ingerida, distando mucho de constituir hasta el 30\% de la MS total como han determinado otros autores (Arenare et al, 1997; Azzarini et al, 1973; Bauzá et al; 2005). Las pasturas utilizadas para engorde de cerdos normalmente realizan un aporte energético del orden de las 2.8 Mcal de ED y 15 a $22 \%$ de proteína digestible por kg de MS. (Bauzá, 2005). Según este autor la digestibilidad de la proteína en general es alta en los forrajes tiernos, hasta que el cultivo madura y aumenta la lignificación de la planta, reduciendo su aprovechamiento por los cerdos. La digestibilidad de las hojas puede variar de $18 \%$ a $84 \%$ con una media de 54\%, la cual es causada por factores genéticos, ambientales, nutricionales y estado fenológico de la planta (Trujillo y Uriarte, 2004). 
El severo déficit hídrico provocó una rápida senescencia de las pasturas reduciendo su disponibilidad y calidad, lo cual pueden haber influido tanto en la reducción del consumo como en el aprovechamiento del alimento.

El aumento en el índice de conversión alimenticia de los animales en el sistema de campo responde a una menor ganancia de peso para un mismo consumo de pienso, lo cual podría corresponderse con la mayor actividad de los animales en pastoreo (Edwards, 2005). Sin embargo, resulta difícil aislar otros componentes del sistema que podrían estar afectando al índice de conversión, como es el caso del ambiente (Hansen et al., 2006; Bee et al., 2004). En términos prácticos, los cerdos parecen haber cubierto sus necesidades alimenticias en base al consumo de pienso, siendo cuantitativamente poco importante el consumo de pastura. Estos resultados sugieren que, para condiciones de marcado estrés hídrico y libre disponibilidad de concentrado, los animales consumen la pastura de forma complementaria como parte de su comportamiento exploratorio, pero no en suficiente cantidad como para reducir el consumo de pienso.

\subsection{Registros ambientales}

En general, los valores obtenidos de nutrientes en suelo antes del ingreso de los animales a las parcelas de pastoreo son concordantes con los esperables para este tipo de suelo según Duran y Garcia-Préchac, 2007). Sin embargo las concentraciones de $\mathrm{NH}_{4}{ }^{+}$y $\mathrm{NO}_{3}{ }^{-}$son menores a lo esperable en suelos de pasturas con leguminosas (Carriquiry et al., 1999; Sawchik, 2001), que pudo ser causado por la reducción balance neto de nitrógeno entre la fijación biológica y el consumo de las plantas forrajeras dado el elevado porcentaje de gramíneas (57\% en 2007 y $67 \%$ en 2008), en comparación con el 20 al 40\% habitualmente manejado en este tipo de pasturas (Risso, 1997). 
Tras una semana de período de pastoreo la concentración de $\mathrm{N}$ total en el suelo se incrementó como era esperable por la contribución de las deyecciones de los cerdos. Sin embargo, ese período de pastoreo no fue suficiente para incrementar significativamente la concentración de $\mathrm{NO}_{3}{ }^{-}$, quedando el nitrógeno excretado principalmente en forma orgánica. Este hecho pudo estar relacionado con que el aporte provenía mayoritariamente de las heces y no de la orina, dado que la deposición de orina en los cerdos se da en las cercanías de las áreas de descanso, mientras que la deposición de heces se tiende a producir en las zonas de actividad (Quintern y Sundrum, 2006). Así, cabe esperar que la cantidad de deyecciones en el área de pastoreo fuera muy baja, tal y como describen Salomon et al. (2007). Estos autores encontraron que sólo un $5 \%$ de los nutrientes excretados eran depositados en el área de pastoreo, siendo la mayor parte excretado en las zonas de refugio, comederos y bebederos.

En el caso del fósforo, la estabilidad en las concentraciones podría derivar de la misma situación, en la cual el contenido de las heces no fue transferido al suelo dado que el lapso de 7 días de pastoreo pudo no ser suficiente para la degradación en condiciones de baja humedad, ya que era observable la desecación de éstas y su permanencia en la superficie. Los modelos de regresión muestran que en plazos mayores, en T2B la concentración de fósforo en el suelo comienza a aumentar hacia el día 60 después del cierre de las parcelas. Sin embargo, en T2 en las mediciones hechas del día 0 al 30 muestran una leve tendencia descendente que podría explicarse mediante un balance de escasa incorporación de fósforo de las heces y una mayor extracción de este nutriente por la pastura. Así, la alta variabilidad de las muestras, y la característica del fósforo de ser muy poco móvil en la solución del suelo y rápidamente retenido por 
las arcillas y la materia orgánica (Duran y Garcia-Préchac, 2007), dificultan poder evaluar la tasa de incorporación de este nutriente al suelo.

Pese a que la movilidad del nitrógeno mineralizado es alta en la solución del suelo, la tendencia de las regresiones obtenidas para las concentraciones de $\mathrm{NH}_{4}^{+}$y $\mathrm{NO}_{3}{ }^{-}$, muestran tendencia a mantenerse estables en T2, por lo que refuerza la hipótesis de muy escasa degradación de las heces y la incorporación al suelo de los nutrientes. En las condiciones estudiadas, la lenta tasa de liberación de los nutrientes es una característica positiva para evitar las pérdidas por lixiviación o escurrimiento superficial, pero esta situación podría diferir en condiciones más húmedas que las estudiadas en este trabajo.

E el área de encierro permanente, donde se concentra la mayor parte de la actividad de los animales y se acumulan las deyecciones a lo largo de todo el ciclo, la concentración de nutrientes se incrementó con el paso del tiempo, lo cual era esperable por el continuo aporte de deyecciones. Sin embargo el caso de los nitratos, en T2B los valores son elevados desde los primeros días y se mantienen con una tendencia estable durante el ciclo, aunque con elevada variabilidad. Los elevados valores iniciales se debieron probablemente a que esa misma parcela había alojado a los cerdos de del anterior estudio (T2) un año antes.

La escasez de precipitaciones en los dos períodos experimentales pudo condicionar las pérdidas de nutrientes del sistema a aquellas que pudieran producirse por volatilización. Sin embargo, en el primer experimento (T2) los eventos de lluvia registrados en los últimos días del período de engorde produjeron una reducción en la concentración de nutrientes. Respecto a esa reducción existen evidencias de que las pérdidas se produjeron tanto por lixiviación como por escurrimiento superficial. El escurrimiento superficial y su arrastre de nutrientes queda demostrado por las muestras recogidas en los 
sistemas de medición de escurrimiento. Aunque no se determinó la pérdida de nutrientes por lixiviación, las características de las precipitaciones y del perfil del suelo evidencian que su cuantía fue escasa. En efecto, la presencia de un horizonte "B textural" con alta concentración de arcillas y muy baja permeabilidad hacen que las pérdidas de nutrientes por escurrimiento profundo sean muy limitadas (Duran and Garcia-Préchac, 2007). En las condiciones estudiadas la sequía provocó una paralización en el crecimiento de las pasturas, con producciones de 535 y $402 \mathrm{~kg} / \mathrm{ha}$ para $\mathrm{T} 2$ y T2B, respectivamente, mientras que una producción promedio se estima en unos $3.600 \mathrm{~kg} / \mathrm{ha}$ durante el mismo período. Por tanto cabe esperar que la retención de nutrientes en los tejidos vegetales no fuera un mecanismo importante en ese período. Según Quintern y Sundrum, (2006) la acumulación de nutrientes en el suelo es uno de los principales riesgos ecológicos de éste tipo de sistemas, no obstante ello dependerá en gran medida de la magnitud de la entrada de nutrientes al sistema y la duración de la restricción hídrica.

En lo que respecta a las pérdidas por emisiones de amoníaco en las parcelas de pastoreo, existe un aumento sustancial comparando la situación previa y posterior a la semana de pastoreo. La volatilización de amoníaco depende del total de nitrógeno amoniacal aportado (Webb et al., 2005b), que en este caso proviene del nitrógeno orgánico rápidamente degradable, fundamentalmente proveniente de la orina. Los valores absolutos registrados están muy por debajo de los reportados por otros autores (Ivanova-Peneva et al., 2008; Basset-Mens et al.,2007) pero las cantidades emitidas son muy dependientes de la intensidad del pastoreo (que en este caso fue baja) y de las diferentes condiciones ambientales, especialmente la humedad del suelo (Misselbrook et al., 2007, Mkhabela et al., 2009). El método utilizado para su estimación podría a su vez estar determinando 
también algunas diferencias, ya que las cámaras estáticas pueden subestimar las emisiones y tienen alta sensibilidad a la variabilidad espacial de las mismas.

La gran variabilidad que se observa entre las mediciones, sugiere que la emisión no es uniforme en toda la superficie como fuera reportado por Watson et al. (2003) y Sommer et al. (2001). Esta disparidad, seguramente esté muy influida por la distribución de las deyecciones y principalmente la existencia o no de deposiciones de orina en la zona donde se colocaba la cámara de medida.

A pesar de ello es posible determinar una tendencia general de las emisiones de $\mathrm{NH}_{3}$ a ser más altas en los primeros días posteriores al pastoreo de las parcelas, para luego reducirse con el transcurso de los días. Esta situación ha sido reportada para la aplicación de purín a pasturas, aunque en estos casos las emisiones son mucho más elevadas en el período de 0 a 48 horas tras la aplicación, con una marcada reducción posterior (Sommer y Hutchings, 2001; Pain et al., 1990; Misselbrook et al., 2004). En este caso, si bien la magnitud de las emisiones es muy inferior a la de aplicación de purines, el efecto se extiende más en el tiempo.

Los resultados obtenidos parecen indicar que, en las condiciones ambientales y de manejo estudiadas, el área de pastoreo está sometida a una baja carga contaminante por aporte de nutrientes, que además pueden permitir la integridad y la persistencia de la pastura. Esto se traduce en leves cambios en el contenido de nutrientes del suelo, y unas pérdidas de nutrientes reducidas por escorrentía y emisión $\left(\mathrm{NH}_{3}\right)$. Por el contrario, el área de encierro permanente es donde se realizan los aportes más importantes de nutrientes, por la presencia continuada de los animales en la misma. La acumulación de nutrientes en esta zona, junto con la eliminación de la cobertura vegetal, pueden comprometer la integridad de la pastura y aumentar las pérdidas de nutrientes por escorrentía, lixiviación o volatilización. Por tanto, si bien es muy complicado cambiar la 
ubicación del área de refugio y alimentación dentro de un ciclo de engorde de los cerdos, sí que debería considerarse entre ciclos consecutivos.

Así pues, es necesario avanzar en el conocimiento que permita establecer una distribución óptima entre las zonas de pastoreo (sometidas a menor carga contaminante) y el encierro permanente, donde se localiza la mayor acumulación de nutrientes y por tanto los mayores riesgos ambientales. Así, para determinar la disposición adecuada de las parcelas de encierro permanente y de pastoreo resulta necesario conocer mejor el comportamiento de estos animales, y a su vez realizar un seguimiento a largo plazo de los nutrientes en el suelo, las emisiones de gases $\left(\mathrm{NH}_{3}\right)$ y las pérdidas por lixiviación y escorrentía.

\section{Conclusiones}

El sistema de producción no afectó el consumo total, sin embargo los animales a campo tuvieron un crecimiento y una eficiencia de conversión alimenticia menor. El aporte de la pastura al consumo total no presenta una gran importancia desde el punto de vista cuantitativo en condiciones de suministro de pienso a libre disponibilidad. En las condiciones estudiadas, la carga animal utilizada en el sistema de pastoreo no tuvo un efecto significativo sobre la concentración de nutrientes en el suelo, excepto $\mathrm{NH}_{4}$ y $\mathrm{NO}_{3}$. Por tanto, en las condiciones y el período de tiempo estudiados, los análisis realizados no confirman que la cría de cerdos a campo constituya una fuente contaminante significativa del suelo. En las parcelas de encierro permanente se producen condiciones de mayor acumulación de nutrientes, lo cual aumenta el riesgo de pérdidas por volatilización o escurrimiento. 


\section{Referencias}

Anderson, N., Strader, R. y Davidson, C. (2003). Airborne reduced nitrogen: ammonia emissions from agriculture and other sources. Environment International 29(2-3), 277-286.

Arenare, L.; Couto, P.; Mauri, P. (1997) Determinación del consumo de alfalfa cortada por cerdos de diferentes categorías. Tesis Ing. Agr., Montevideo, Uruguay, Facultad de Agronomía. 68 p.

Azzarini, A.; Estevez, R.; Ruiz, M. (1973) Influencia del pastoreo en la economía de los concentrados en la preparación de los cerdos para el mercado. Primer Congreso Nacional de Producción Animal. Paysandú. Facultad de Agronomía. $23 \mathrm{p}$.

Barloco, N. (2005). Alimentación de cerdos en crecimiento y engorde, en pastoreo permanente. Utilización de Pasturas en la alimentación de cerdos, 15-21. Montevideo.Facultad de Agronomía.

Barloco, N. (2007). Recría y terminación de cerdos en condiciones pastoriles. IX Encuentro de Nutrición y Producción en Animales Monogástricos, 87-94. Montevideo, UDELAR, INIA.

Basset-Mens, C., van der Werf, H. M. G., Robin, P., Morvan, T., Hassouna, M., Paillat, J. M. y Vertès, F. (2007). Methods and data for the environmental inventory of contrasting pig production systems. Journal of Cleaner Production 15(15), 1395-1405.

Bauzá, R. (2005). Uso de pasturas en el crecimiento-terminación de cerdos:pastoreo con acceso restringido. Utilización de Pasturas en la alimentación de cerdos, 23-31. Montevideo. Facultad de Agronomía. 
Bauzá, R., González, A., Panissa, G., Petrocelli, H. y Miller, V. (2005). Evaluación de dietas para cerdos en recría incluyendo forraje y suero de queso. Revista Argentina de Producción Animal, 25, pp. 11-18.

Bee, G., Guex, G. y Herzog, W. (2004). Free-range rearing of pigs during the winter: Adaptations in muscle fiber characteristics and effects on adipose tissue composition and meat quality traits. Journal of Animal Science 82(4), 12061218.

Canh, T. T., Verstegen, M. W. A., Aarnink, A. J. A. y Schrama, J. W. (1997). Influence of dietary factors on nitrogen partitioning and composition of urine and feces of fattening pigs. Journal of Animal Science 75(3), 700-706.

Carpenter, S. R. (2005). Eutrophication of aquatic ecosystems: Bistability and soil phosphorus. Proceedings of the National Academy of Sciences of the United States of America 102(29), 10002-10005.

Carriquiry, M., Morón, A. y Sawchik, J. (1999). Potencial de mineralización de Nitrógeno en suelos del área agrícola del Uruguay. Actas del XIV Congreso latinomaericano de Ciencia del Suelo. Temuco, Chile.

DIEA. (2007). Encuesta Porcina 2006. Caracterización de la situación productiva, tecnológica, comercial y social del sector porcino. FPTA, MGAP-INIA, 170, pp. 1-71. Montevideo.

DIEA. (2010). Anuario Estadístico 2010. MGAP. Montevideo.

Dourmad, J. Y., Seve, B., Latimier, P., Boisen, S., Fernandez, J., Peet-Schwering, C. y Jongbloed, A. W. (1999). Nitrogen consumption, utilisation and losses in pig production in France, The Netherlands and Denmark. Livestock Production Science 58(3), 261-264. 
Duran, A. y Garcia-Préchac, F. (2007). Los suelos del Uruguay. Origen, clasificación, manejo y conservación.1[1], Hemisferio Sur, Montevideo.

Edwards, S. A. (2005). Product quality attributes associated with outdoor pig production. Livestock Production Science 94(1-2), 5-14.

Franklin, D. H., Cabrera, M. L., Steiner, J. L., Endale, D. M. y Miller, W. P. (2001). Evaluation of percent flow captured by a small in-field runoff collector. Transactions of the Asae, 44(3), pp. 551-554.

Hansen, L. L., Claudi-Magnussen, C., Jensen, S. K. y Andersen, H. J. (2006). Effect of organic pig production systems on performance and meat quality. Meat Science 74(4), 605-615.

INIA-GRAS (2009) Monitoreo Mensual de la Vegetación. Sistemas de Información y teledetección. www.inia.org.uy

Inouye R.S. y Tilman, D. (1995). Convegence and divergence of old-field vegeatation after 11 years of nitrogen addition. Ecolgy 76, 1872-1877.

IPCC. (2006). Emissions from Livestock and Manure Management. En: 2006 IPPC Guidelines for National Greenhouse gas Inventories. Volume 4: Agriculture, Forestry and other Land Use. Pag. 1-87. Hayama (Kanagawa), Japan.

IRI (2012). ENSO Quik Look. http://iri.columbia.edu/climate/ENSO/currentinfo/ QuickLook.html. Last modified: 01/19/2012

Ivanova-Peneva, S. G., Aarnink, A. J. A. and Verstegen, M. W. A. (2008). Ammonia emissions from organic housing systems with fattening pigs. Biosystems Engineering 99(3), 412-422.

Kruk, C.; Rodríguez-Gallego, L. ; Meerhoff, M., Quintans, F. ; Lacerot, G. ; Mazzeo, N.; Scasso, F. ; Paggi, J.; Peeters, E. y Marten, S. (2009). Determinants of 
biodiversity in subtropical shallow lakes (Atlantic coast, Uruguay). Freshwater Biology 54(12), 2628-2641.

Leborgne,R. (1983) Antecedentes técnicos y metodología para presupuestación en establecimientos lecheros. $2^{2}$ ed. Hemisferio Sur, Montevideo. 54p.

Krupa, S. V. (2003). Effects of atmospheric ammonia (NH3) on terrestrial vegetation: a review. Environmental Pollution 124, 179-221.

Melse, R. W., Ogink, N. W. M. y Rulkens, W. H. (2009). Overview of European and Netherlands' regulations on airborne emissions from intensive livestock production with a focus on the application of air scrubbers. Biosystems Engineering 104(3), 289-298.

MET URUGUAY (2009) Características climáticas del Uruguay. http://meteorologiauruguay.blogspot.com/2009/04/caracteristicas-climaticasde-uruguay.html

MGAP, INIA, FAGRO y INAC. (2005). Evaluación Bioeconómica de Sistemas de Producción de Cerdos. FPTA, INIA, 130. Montevideo.

Milne, J. A. (2005). Societal expectations of livestock farming in relation to environmental effects in Europe. Livestock Production Science 96(1), 3-9.

Misselbrook, T., Martinez, J. y Huijsmans, J. (2007). Gaseous emissions from agricultural systems. Papers presented at the 11th Conference of the FAO Escorena Network on Recycling of Agricultural, Municipal and Industrial Residues in Agriculture (RAMIRAN), 'Sustainable Organic Waste Management for Environmental Protection and Food Safety', Murcia, Spain, 6-9 October 2004. Biosystems Engineering 97(4), 429-532. 
Misselbrook, T. H., Smith, K. A., Jackson, D. R. y Gilhespy, S. L. (2004). Ammonia emissions from irrigation of dilute pig slurries. Biosystems Engineering 89(4), 473-484.

Mkhabela, M. S., Gordon, R., Burton, D., Smith, E. y Madani, A. (2009). The impact of management practices and meteorological conditions on ammonia and nitrous oxide emissions following application of hog slurry to forage grass in Nova Scotia. Agriculture, Ecosystems \& Environment 130(1-2), 41-49.

Moliterno, E. (1986). Medición de Pasturas. Facultad de Agronomía, (469), pp. 1-9. Paysandú, Uruguay.

Noblet J. y Pérez. J. M. (1993) Prediction of digestibility y of nutrients and energy values of pig diets from chemical analysis. Journal of Animal Science. 71, 33893398.

Pain, B. F., Phillips, V. R., Clarkson, C. R., Misselbrook, T. H., Rees, Y. J. y Farrent, J. W. (1990). Odour and ammonia emissions following the spreading of aerobically-treated pig slurry on grassland. Biological Wastes 34(2), 149-160.

Payet, N., Findeling, A., Chopart, J. L., Feder, F., Nicolini, E., Saint Macary, H. y Vauclin, M. (2009). Modelling the fate of nitrogen following pig slurry application on a tropical cropped acid soil on the island of Reunion (France). Agriculture, Ecosystems \& Environment 134(3-4), 218-233.

Quintern, M. y Sundrum, A. (2006). Ecological risks of outdoor pig fattening in organic farming and strategies for their reduction--Results of a field experiment in the centre of Germany. Agriculture, Ecosystems \& Environment 117(4), 238250. 
Risso, D. (1997) Producción de carne sobre pasturas: Suplementación estratégica para el engorde de ganado. Serie técnica (83) 1-10, INIA La Estanzuela, Colonia, Uruguay.

Ropelewski, C.F., Halpert, M.S. (1987). Global and regional scale precipitation patterns associated with the El Niño / Southern Oscillation. Monthly Weather Review 115, 1606-1626.

Salomon, E., Hkerhielm, H., Lindahl, C. y Lindgren, K. (2007). Outdoor pig fattening at two Swedish organic farms-Spatial and temporal load of nutrients and potential environmental impact. Agriculture, Ecosystems \& Environment 121(4), 407-418.

SAS Institute Inc. (2008). SAS/STAT 9.2. User's Guide, SAS Institute Inc., Cary, NC (2008).

Sawchik, J. (2001). Dinámica del nitrógeno en la rotación cultivo-pastura bajo laboreo convencional y siembra directa. Edición: Díaz-Rosello, R. En: Siembra Directa en el Cono Sur. PROCISUR.

Sommer, S. G. y Hutchings, N. J. (2001). Ammonia emission from field applied manure and its reduction - invited paper. European Journal of Agronomy 15, 115.

Sommer, S. G., Sogaard, H. T., Moller, H. B. y Morsing, S. (2001). Ammonia volatilization from sows on grassland. Atmospheric Environment 35, 20232032.

SSSA. (1986a). Core method. In: SSSA Book Series: 5 Methods of Soil Analysis. Part 1 Physical and Mineralogical Methods, ASA. SSSA. Madison Wisconsin USA. 364-365. 
SSSA. (1986b). Pressure cell apparatus "Richards". In: SSSA Book Series: 5 Methods of Soil Analysis. Part 1 Physical and Mineralogical Methods, ASA. SSSA. Madison Wisconsin USA. 635-660.

Trujillo, I. y Uriarte, G. (2011) Valor nutritivo de las PASTURAS. Curso de Nutrición Facultad de Agronomía. http://prodanimal.fagro.edu.uy/cursos/NUTRICION/TEORICOS/Tema 2. Última actualización 29-3-2011

USDA. (1972). Pipet Method. USDA - Soil Conservation Service. Soil Survey Investigations Report No. 1 Washington. 63 p.

Viñas, M. y Gutiérrez, S. (2008). Estimación de los parámetros nacionales y básicos para el procesamiento y utilización de residuos sólidos y líquidos de tambos. FPTA, INIA, 138.

Watson, C. A., Atkins, T., Bento, S., Edwards, A. C. y Edwards, S. A. (2003). Appropriateness of nutrient budgets for environmental risk assessment: a case study of outdoor pig production. European Journal of Agronomy 20(1-2), 117126.

Webb, J., Anthony, S. G., Brown, L., Lyons-Visser, H., Ross, C., Cottrill, B., Johnson, P. y Scholefield, D. (2005a). The impact of increasing the length of the cattle grazing season on emissions of ammonia and nitrous oxide and on nitrate leaching in England and Wales. Agriculture, Ecosystems \& Environment 105(12), 307-321.

Webb, J., Menzi, H., Pain, B. F., Misselbrook, T. H., Dammgen, U., Hendriks, H. y Dohler, H. (2005b). Managing ammonia emissions from livestock production in Europe. Environmental Pollution 135(3), 399-406. 
Williams, A. E., Lund, L. J., Johnson, J. A. y Kabala, Z. J. (1998). Natural and anthropogenic nitrate contamination of groundwater in a rural community, California. Environmental Science and Technology 32, 32-39. 


\section{Capítulo 5}

Ethologic, physiologic and meat characterization of extensive and intensive pig production systems in Uruguay 



\section{Abstract}

More than $60 \%$ of pig existences in Uruguay are produced in systems which include outdoor production with variable participation of pastures in feed stuffs. The outdoors pig production has a good reputation worldwide as regards to animal welfare, but little information is generated in Latin America on behavioral factors and welfare in different local production systems. The aim of this work is to characterize two contrasting systems of fattening pigs. Total 96 pigs (mean 41.7 $\mathrm{kg}$ ) were divided into groups of 12 animals, with four replicates per treatment, representing two production systems: (T1) confined in pens of $12 \mathrm{~m}^{2}$ and (T2) pigs kept in parcels wit field shelters and access to pasture. Behavioral observations were performed by "scan sampling" at intervals of 5 minutes, three times a day for two hours (7:00-9:00,13:00-15:00 and 18:00 to 20:00) during the week 6, 8, 10 and 12. Blood samples were taken for cortisol analysis and other physiological parameters, during growth period and slaughterhouse. Differences were found in meat characteristics, where T1 presented a higher dorsal fat presented a lower overall activity and less time spent resting, with a stable pattern throughout the day. In T2, pigs usually rested at midday hours, being more active in the morning and afternoon. The number of reciprocal aggression in the observation period was $4.2 \pm 3.7$ for T1 and $2.3 \pm 2.2$ for T2, p = 0.0359. Cortisol levels in (a) were $6.6 \pm$ 2.74 and (b) $5.0 \pm 2.01, p<0.0001$ at the farm level, and $15.9 \pm 4.30$ vs. $13.0 \pm 4.04$ respectively at slaughter, $p=0.0023$. It is concluded that welfare is not compromised in any of the systems, but higher levels of cortisol and aggression could be indicating some stress problems in confinement system. Meat characteristics in $\mathrm{T} 2$ are better from a nutritional point of view, but could have inadequate quality for industry. 



\section{Introduction}

World pig production has increased by 34\% from 1996 to 2006 (FAOSTAT, 2008). Domestic pork demand in most of Latin American countries has been unstable in the last decades (Orr and Shen, 2006), in which market vulnerability due to economic shocks has been an important driving force (Canfield, 2006). In Uruguay, this situation led the sector to the search of new alternatives to reduce economical uncertainty by reducing infrastructure investments and the feeding cost, using pastures as a tool to reduce concentrates intake (Barloco, 2007). Due to these circumstances, nowadays a great diversity in production systems coexists in the country. This includes more than $60 \%$ of pig existences in systems which include outdoor production with variable participation of pastures in feed stuffs (DIEA, 2007). During last years, the interest in these production systems has increased due to different causes. The increasing pig meat consumption in the internal market (DIEA, 2010) with a big relative importance of fresh meat (DIEA, 2007), has been followed by new demands of consumers. Related to this, some characteristics of outdoor production systems with pastures, like environmental sustainability and natural meat production (Barloco, 2007) or the social importance of the sector (Oyhantçabal, 2010) are becoming attractive for consumers. Furthermore, other characteristics of these production systems affecting animal welfare and product quality have also to be considered, because they have a growing societal and scientific importance (Smulders et al., 2006). Free range models tried to harmonize the exploitation of natural resources, the increase in animal welfare, and the improvement in production quality. In this way, the production model of "a campo" in Argentina, Uruguay, or Venezuela, ar examples of new extensive pig production methods (Aparicio Tovar and Vargas Giraldo, 2006). 
These systems also result in produced pigs with different meat characteristic do to exercise (Daza et al., 2009) or do to pasture intake (Moisá et al., 2007) wich could affect pH (Bee et al., 2004), fat deposition (Gentry et al., 2002), fatty acid profile (Daza et al., 2009) and also meat colour (Echenique et al., 2009a).

Animal welfare involves the physical and mental health of animals (Dawkins, 2004), but there is no agreement on how to measure welfare and how to interpret changes in behaviour and physiology (Barnett, 2007). One of the most controversial issue in order to evaluate welfare is the confinement of animals (Barnett, 2007) whose poor environment offers little potential to accommodate their highly motivated specie-specific behaviours (van de Weerd and Day, 2009).

Changes in behavioural patterns often represent the first level of response of an animal to an aversive or stressful environment (Temple et al., 2011). Several aspects of behaviour have been used to evaluate confinement effects or to compare it with outdoor systems: social behaviour, both negative (Weng et al., 1998; Barnett et al., 1993; Ewbank and Bryant, 1972; Deen, 2010) and positive (Temple et al., 2011), exploratory behaviour (Beattie et al., 2000; Stolba and Wood-Gush, 1981; Docking et al., 2008), development of abnormal behaviour (Lawrence and Terlouw, 1993; Moinard et al., 2003) or resting time (Scott et al., 2006; Beattie et al., 1995) among others. Furthermore, although behaviour is an important aspect of welfare qualification, it is not enough, and there are behavioural and physiological responses that are used collectively to measure animal welfare (Barnett, 2007). Animal health is one of the most important aspects considered to evaluate welfare (Broom, 2006) and biochemical serum profile is also a common method to assess it (Adams et al., 2008; Chorfi et al., 2007). Nevertheless, cortisol is the physiological parameter more widely used due to its association with stress. High plasma or serum concentration of cortisol is 
clearly associated to acute stressors (Barnett et al., 1996; Rushen et al., 1995) or to a permanent social stress in animals reared in poor environments (de Jonge et al., 1996). However, in the evaluation of stress it is important to consider the circadian rhythm of cortisol in relation to age, gender, the time of presence of the stressor (Ruis et al., 1997) and intra-individual variation (Mormede et al., 2007). Thus, assessment of stress must be based on a wide range of variables describing the process (Jensen et al., 2004).

In this context, the main objective of the present work is to characterize two contrasting systems of fattening pigs, the traditional one with animals confined in pens and an alternative outdoor system with pasture access. This study is focused on productivity, meat characteristics, general and social behaviour, and physiological indicators in order to bring a tool to evaluate the possibilities of both systems to face up to consumer demands.

\section{Material and methods}

\subsection{Animals and Housing}

Two trials were carried out at Las Brujas Experimental Centre of the National Agricultural Research Institute (INIA) of Uruguay. The first experimental period lasted 12 weeks, from October $23^{\text {th }}$ of 2007 to January $16^{\text {th }}$ of 2008 , representing a mid spring to early summer period. The second lasted 12 weeks, from September $23^{\text {th }}$ to December $16^{\text {th }}$ of 2008.

For the first trial, 96 pigs Landrace $x$ Large Withe (Delta híbrido) of 12 weeks old, and $41.7 \mathrm{~kg}$ average live weight (48 females and 48 castrated males) were used. Animals were individually identified with a plastic ear tag and randomly divided into eight groups of six females and six males each. Four groups were assigned to treatment 1 (T1), which consisted on a conventional indoor confined fattening 
system and the rest to (T2), an outdoor system, with free access to a grassland parcels.

For the second trial 48 pigs of the same commercial line, 14 weeks old and $53.2 \mathrm{~kg}$ average live weight were used. Animals were also individually tagged and assigned to four groups of a unique treatment (T2b), which was a replicate of T2.

In T1, pigs were housed in a natural ventilation building, in pens with twelve square meters surface. Floor surface was $25 \%$ plastic slat and $75 \%$ solid concrete (see Figure1).

In T2 and T2b, pigs were housed in a $20 \times 10$ m yard built with electric wire, with a twelve square meters wood hut (permanent parcel, see Figure 2). Each group had free access to a 170 square meters grassland parcel also built with electric wire. Every week a new grazing parcel was available for each group and the access to the previous one was closed (see Figure 3).

In all groups animals were fed ad-libitum with the same diet, with nutrient contents (\%) of: 88.9 $\pm 1.1 \mathrm{DM}, 14.9 \pm 1.6 \mathrm{CP}, 13.2 \pm 8.4 \mathrm{ADF}, 34 \pm 9.1 \mathrm{NDF}, 3.98 \pm 0.9 \mathrm{EE}$ and $4.7 \pm 0.4$ of ash. Pasture in $T 2$ and $T 2 b$, was a seeded prairie with a mix of white clover, red clover and ryegrass. 


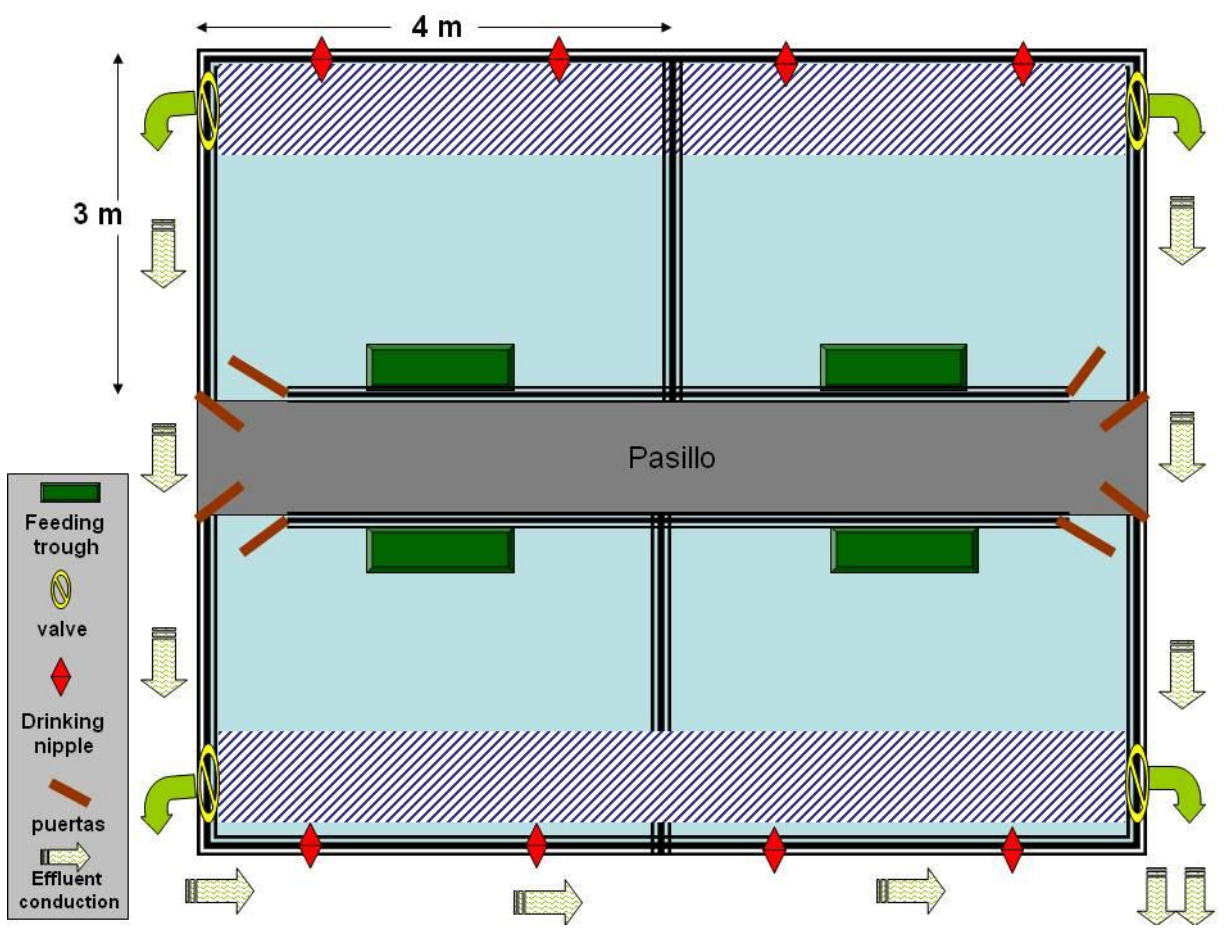

Figure 1. Housing diagram of treatment T1

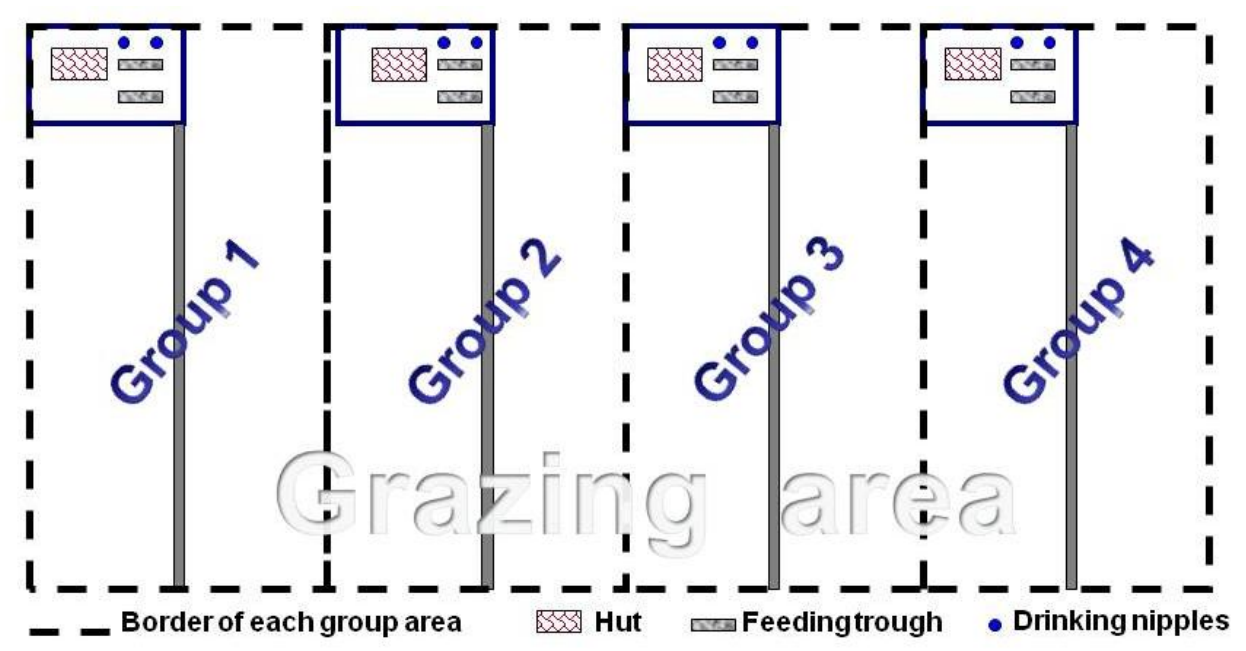

Figure 2. Housing diagram and distribution of groups in treatments $T 2$ and $T 2 b$ 


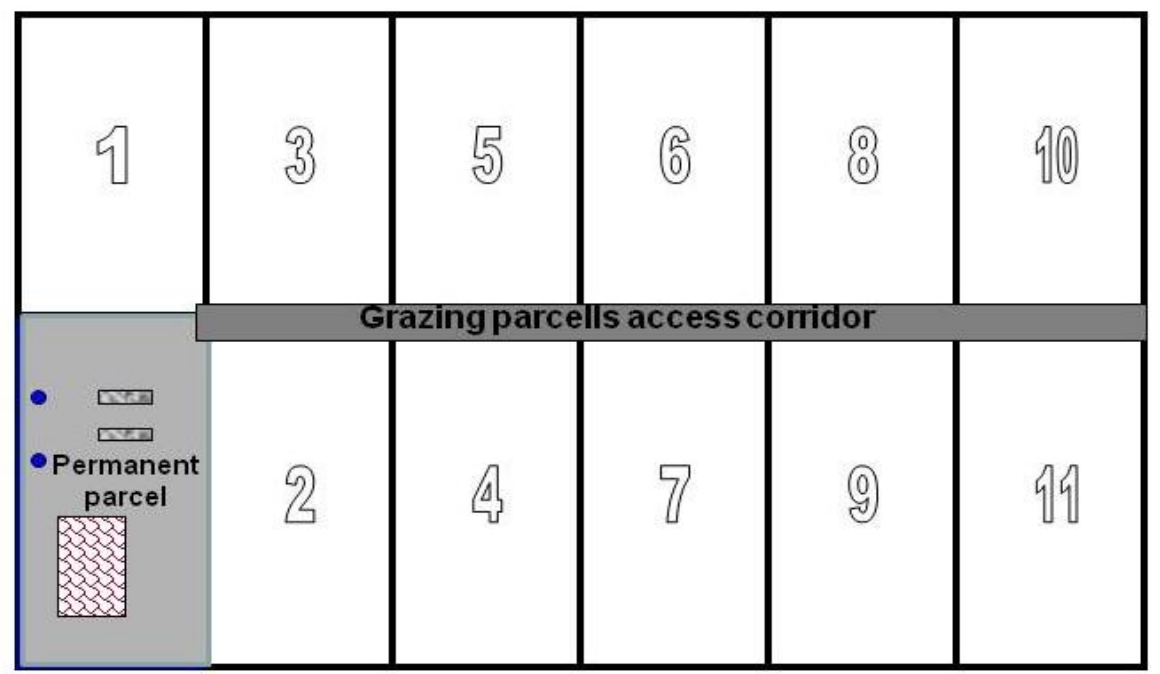

Figure 3. Housing diagram and distribution of grazing parcels in treatments T2 and $\mathrm{T} 2 \mathrm{~b}$

\subsection{Production, carcass and meat measures.}

Individual live weight and group feed intake was weekly measured. Pasture intake was calculated by difference between offering and remaining with standard method (Moliterno, 1997). Samples were taken at the moment of opening the new parcels (before the animals income) and one week after its closing. Samples of concentrate and pasture were analyzed determining dry matter, total protein, neutral detergent fibber and acid detergent fibber in pasture. Total fat, phosphorus, calcium and total mineral were also analyzed for concentrate samples. Group feed conversion rate was estimated by dividing weekly feed intake and the summatory of weekly individual live weight gain.

Animal were slaughtered at 169 days of age, after 2 hours transport and 6 hours lairage in an unique padock. Six animals per group in T1 and T2 were selected for 
carcass and meat studies as described by (Gispert et al., 2007). Carcass length (CL), $\mathrm{pH} 45$ min post-mortem ( $\mathrm{pH} 45$ ), dorsal fat thickness $(\mathrm{mm})$ at gluteus medium (DFTGM), dorsal fat thickness (mm) at last rib (DFTLR) and pH 24 hours postmortem ( $\mathrm{pH} 24)$ were registered at the slaughterhouse. Muscle colour was measured in loin eye at the firs steak level, with a Minolta C10 colorimeter, determining parameters $L^{*}$ (lightness), a* (redness/greenness) and $b^{*}$ (yellowness/blueness). Chroma (C) and Hue angle ( $\mathrm{H} \circ$ ) values were obtained by using the following equations: $\mathrm{C}=(\mathrm{a} * 2+\mathrm{b} * 2)^{0.5} ; \mathrm{H}=\mathrm{o}=\operatorname{arctg} \mathrm{b} * / \mathrm{a} *$.

Fat samples for fatty acids analysis were taken in the same animals from dorsal fat at last rib. This lipids profile was analysed by liquid chromatography in the Nutrition Laboratory of the Chemistry Faculty of the Republic University, determining individual fatty acids contents, total saturated fatty acids (SFA), total monounsaturated fatty acids (MUFA) and total polyunsaturated fatty acids (PUFA). These measurements were not carried out in T2b pigs as were not processed in the slaughterhouse.

\subsection{Behavioural observations}

Behaviour of outdoor system pigs ( $T 2$ and $\mathrm{T} 2 \mathrm{~b}$ ), was directly observed in three daily periods of two hours (morning -7:00 to 9:00-, midday -13:00 to 15:00- and afternoon $-18: 00$ to $20: 00$ ), three alternative days a week, during four weeks, $(6,8,10$ and 12). Observations were carried out by scan sampling every five minutes, registering the number of pig performing each of the behaviours described in Table 1. Ethogram was partially adapted from Morgan et al. (1998) and Bolhuis et al. (2005) 
Table 1. Description of registered behaviour

\begin{tabular}{ll}
\hline Behaviour & Description \\
\hline Eating (EC) & Animal with the head into the feed trough or chewing \\
Drinking (D) & Animal with its mouth in drinking nipple \\
Grazing (G) & Animal with its head into vegetation or chewing pasture. \\
Walking (W) & Animal moving without other distinguished behaviour \\
Exploring (E) & Smelling, touching with nose, or rooting any material or floor \\
Hut (H) & Animal staying inside the hut \\
Resting (R) & Animals with body recumbent on sternum or side, and pigs \\
Mud resting (M) & $\begin{array}{l}\text { Animal resting in the mud } \\
\text { Interaction (I) }\end{array}$ \\
Ather (O) & $\begin{array}{l}\text { Onimal fighting or playing with fisical contact } \\
\end{array}$
\end{tabular}

In addition, two variables $\mathrm{A}$ and $\mathrm{P}$ were created by integrating active behaviours ( $E C, D, G, W, E, I$ and $O)$ and passive behaviour $(H, R, M)$.

Considering that outdoor pigs' resting behaviour, was mainly developed inside the huts, a variable was created in order to compare resting behaviour of T1 in relation to $T 2$ and $T 2 b$. This variable (TR) resulted from integrating $R$ and $H$ for $T 2$ and $\mathrm{T} 2 \mathrm{~b}$, and in $\mathrm{T} 1$ it was considered that $\mathrm{TR}=\mathrm{R}$.

Aggressive behaviour was also registered in the first trial in T2 during weeks 11 and 12 every two days. Two observers registered aggressions between animals by continuous observation in two periods of half hour duration: one in the morning 
(randomly for each group, 9:00 to 9:30 or 9:30 to 10:00) and other in the afternoon (randomly 18:00 to $18: 30$ or $18: 30$ to $19: 00$ ).

Furthermore, three levels of aggression were established: aggression from one animal to other without response of the second (unidirectional aggression, $U$ ), aggression from one animal to other with response of the second (reciprocal aggression, R) and fight, which was described as a reciprocal aggression during at least five seconds (F). In all observations, the activity performed by the pigs at the moment of the aggression was also registered. Animals under T1 were continuously recorded with video camera and behavioural observations were carried out in the same periods, at weeks 10 and 12 of the experiment. Agonistic behaviour was registered at the same periods and dates than $\mathrm{T} 2$.

\subsection{Physiological parameters}

Blood samples of six randomly selected pigs of each group were taken on day 84 of the experiment, during the weightening routine, for the three treatments and in the slaughterhouse at the moment of sticking for T1 and T2. Samples were collected in $7 \mathrm{~mL}$ vacuum tubes without anti anticoagulant and immediately refrigerated and taken to the laboratory, where they were centrifuged at 3000 rpm for $15 \mathrm{~min}$ at $4{ }^{\circ} \mathrm{C}$, as described by Titto et al. (2010). Serum was then removed and transferred to eppendorf tubes $(1.5 \mathrm{~mL})$ for storage at $-40 \circ \mathrm{C}$ until the analyses were made. Each sample was divided into three tubes: one for cortisol, one for biochemical profile and the other for backup.

Serum samples were assayed in the Laboratory of Nuclear Techniques, Veterinary Faculty, Montevideo, Uruguay. Cortisol concentrations were determined by a direct solid-phase radioimmunoassay (RIA) using DPC kits (Diagnostic Product Co., Los Angeles, CA, USA). The RIA had a sensitivity of $0.52 \mathrm{ug} / \mathrm{dL}$. All samples were 
determined in the same assay. The intra-assay coefficients of variation for low (1.28 ug/dL), medium (5.91 ug/dL) and high (17.05 ug/dL) were $10.89 \%, 7.13 \%$ and $2.58 \%$ respectively.

Finally, thirteen biochemical parameters were determined by IDEXX VetTest ${ }^{\circledR}$ Chemistry Analyzer: Creatinine Kinase (CK), Gamma Glutamine Transferase (GGT) Alanine Trasnpherase (ALT) Glucose (GLU), Globuline (GLOB), Total Protein (TP), Alkaline Phosphatase (ALKP), Calcium (Ca), Total Bilirubine (TBIL), Urea (BUN), Creatinine (CREA), Cholesterol (CHOL) and Amylase (AMYL).

\subsection{Statistical analysis}

All data were analyzed with Statistical Analysis System package 9.2 (SAS Institute Inc, 2008).

Live weight and average daily gain were analyzed by Mixed Procedure with repeated measurement design (animal as repeated subject), with treatment as fixed effect, and week, animal and group as random effect. A General Linear Model Procedure was performed for meat characteristics, cortisol concentration and biochemical blood profile. Cortisol and biochemical database were previously transformed into natural logarithm in order to normalize the residuals.

For general behaviour and aggression, the statistical unit was the group. Behaviour data were transformed prior to the analysis into relative numbers (proportion of pigs within a group doing each activity; mean of the observation period) and LN transformed to normalize residuals. Treatment effects on each behaviour were evaluated using linear mixed models (proc MIXED) with repeated measurement design (group as repeated subject) and a compound symmetry covariance structure (type=cs). The model included treatment $(T 1, T 2$ and $T 2 b)$, period of observation (morning, midday and afternoon) and the interaction 
between treatment and period as fixed effects. Effects were corrected for multiple testing with Tukey test, with $p \leq 0.05$ level of significance (Baumgartner et al., 2010).

Regarding aggression data, these were logarythmically transformed in order to normalize the residuals. Thereafter, data were analyzed by PROC MIXED with repeated measurement design (group as repeated subject), with treatment and moment of the day as fixed effects. Effects were corrected for multiple testing with Tukey test, with $p \leq 0.05$ level of significance.

\section{Results}

\subsection{Production, carcass and meat characteristics}

Average weekly gain showed significant differences $(p=0.0126)$ between T1 and T2, being $5.5 \pm 1.7$ and $5.1 \pm 1.9 \mathrm{~kg}$, respectively. However, considering the comparison into each week only significant differences $(p<0.001)$ of weight gain were found for the third week of the experiment. It resulted in higher average live weight in $\mathrm{T} 1$ since then, which remained during all the experiment as it can be observed in Figure 4. Average weekly gain in T2b was $4,5 \pm 2.1$, but the growing traits are not compared with $\mathrm{T} 1$ and $\mathrm{T} 2$ because of the different age and weight of the animals at the beginning of the experiment. 


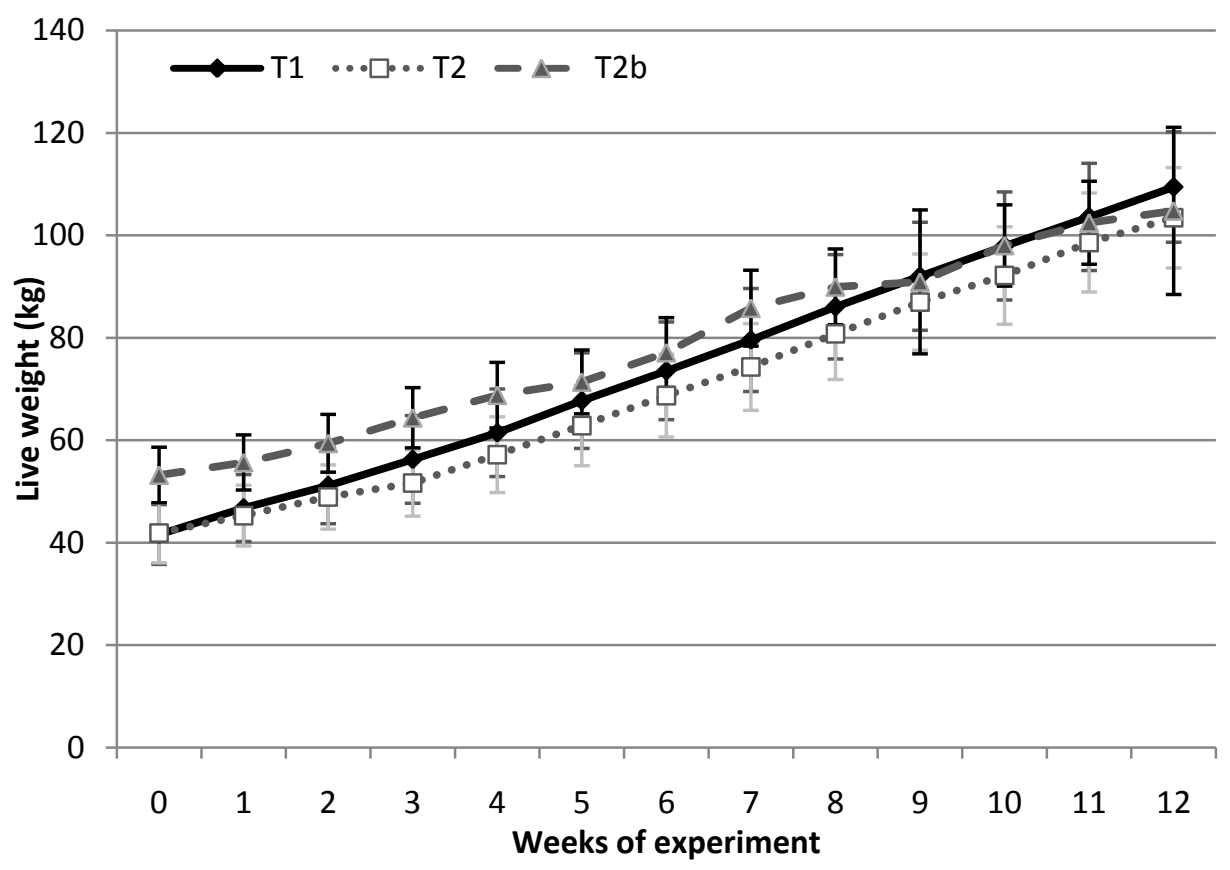

Figure 4 - Live weight evolution of pigs in the three treatments for the whole experiment (means $\pm S D$ ).

Results of carcass measurements and meat colour are presented in Table 2. Dorsal fat thickness was higher in $\mathrm{T} 1$ as compared with $\mathrm{T} 2$, whereas no differences were found for $\mathrm{pH} 45$ and $\mathrm{pH} 24$. Meat colour did not present either significant differences for $a, b$, Chroma and Hue angle but $\mathrm{T} 2$ showed a higher $\mathrm{L}$. 
Table 2 - Canal traits and meat colour in pigs reared in indoor traditional system (T1) or outdoor with pasture system (T2)

\begin{tabular}{ccccc}
\hline & Treatment & T1 & T2 & p \\
\cline { 3 - 4 } & & \multicolumn{2}{c}{ Means \pm SD } & \\
\cline { 2 - 4 } Canal traits & DFTGM & $30.7 \pm 7.64$ & $26.9 \pm 6.02$ & 0.0438 \\
& DFTLR & $33.7 \pm 4.92$ & $29.8 \pm 5.28$ & 0.0045 \\
& PM & $75.7 \pm 24.00$ & $74.3 \pm 22.00$ & N.S. \\
& CL & $815.6 \pm 20.20$ & $808.4 \pm 19.14$ & N.S. \\
& pH45 & $6.26 \pm 0.32$ & $6.15 \pm 0.36$ & N.S. \\
& pH24 & $5.70 \pm 23.00$ & $5.67 \pm 15.00$ & N.S. \\
\hline \multirow{4}{*}{ Meat colour } & L & $50.41 \pm 2.70$ & $48.12 \pm 3.55$ & 0.0339 \\
& $\mathrm{a}$ & $7.33 \pm 2.06$ & $7.49 \pm 2.06$ & N.S. \\
& $\mathrm{b}$ & $11.18 \pm 1.53$ & $10.61 \pm 1.77$ & N.S. \\
& Chroma & $13.4 \pm 2.33$ & $13 \pm 2.61$ & N.S. \\
& Hue & $57.3 \pm 4.64$ & $55.3 \pm 3.28$ & N.S. \\
\hline
\end{tabular}

Regarding fatty acids profile, results are displayed in Table 3. As it can be observed, MUFA and Trans acids resulted significantly higher in T1 while PUFA were higher in T2. Nevertheless, individual unsaturated fatty acids showed different patterns depending on the type of acid for both treatments. As regards to individual monounsaturated fatty acids, only 18:1 showed significant differences, with higher values in T1, while 16:1 and 20:1 did not differ between treatments. 
Table 3 - Fatty acid composition (\% of total fat) of back fat in pigs reared in indoor traditional system (T1) or outdoor with pasture system (T2)

\begin{tabular}{|c|c|c|c|}
\hline Fatty acids & T1 & T2 & $p$ value \\
\hline $14: 00$ & $1.17 \pm 0.12$ & $1.15 \pm 0.16$ & 0.7232 \\
\hline $16: 00$ & $23.16 \pm 1.33$ & $22.77 \pm 1.26$ & 0.2672 \\
\hline $16: 1$ cis & $1.48 \pm 0.21$ & $1.47 \pm 0.23$ & 0.8856 \\
\hline $17: 00$ & $0.55 \pm 0.14$ & $0.39 \pm 0.07$ & $<0.0001$ \\
\hline $18: 00$ & $12.57 \pm 1.70$ & $12.43 \pm 1.21$ & 0.7436 \\
\hline $18: 1$ trans & $0.19 \pm 0.06$ & $0.11 \pm 0.04$ & 0.0065 \\
\hline $18: 1 \mathrm{cis}$ & $41.79 \pm 1.56$ & $40.46 \pm 1.54$ & 0.004 \\
\hline $18: 2$ trans & $0.01 \pm 0.03$ & $0.00 \pm 0.00$ & 0.048 \\
\hline $18: 2$ cis & $14.88 \pm 1.66$ & $16.86 \pm 2.04$ & 0.0002 \\
\hline 20:00 & $0.20 \pm 0.04$ & $0.20 \pm 0.02$ & 0.9676 \\
\hline $20: 1$ cis & $0.62 \pm 0.09$ & $0.6 \pm 0.09$ & 0.4342 \\
\hline $18: 3$ cis & $0.82 \pm 0.11$ & $0.99 \pm 0.14$ & $<0.0001$ \\
\hline $20: 2$ cis & $0.54 \pm 0.06$ & $0.59 \pm 0.08$ & 0.0328 \\
\hline $20: 3$ cis & $0.10 \pm 0.02$ & $0.09 \pm 0.00$ & 0.2827 \\
\hline $20: 4$ cis & $0.21 \pm 0.03$ & $0.23 \pm 0.05$ & 0.0529 \\
\hline$\Sigma$ Saturated (SFA) & $37.64 \pm 2.84$ & $36.91 \pm 1.93$ & 0.2882 \\
\hline$\Sigma$ Monounsaturated (MUFA) & $43.89 \pm 1.65$ & $42.53 \pm 1.59$ & 0.0045 \\
\hline$\Sigma$ Polyunsaturated (PUFA) & $16.56 \pm 1.81$ & $18.76 \pm 2.22$ & 0.0001 \\
\hline PUFA:SFA & $0.44 \pm 0.08$ & $0.51 \pm 0.08$ & 0.0049 \\
\hline MUFA:SFA & $1.16 \pm 0.13$ & $1.17 \pm 0.08$ & 0.5414 \\
\hline$n-3$ & $0.92 \pm 0.11$ & $1.10 \pm 0.14$ & $<0.0001$ \\
\hline$n-6$ & $15.39 \pm 1.69$ & $17.48 \pm 2.07$ & 0.004 \\
\hline$n-6: n-3$ & $16.75 \pm 0.90$ & $15.92 \pm 0.79$ & 0.014 \\
\hline$\Sigma$ Trans & $0.16 \pm 0.08$ & $0.11 \pm 0.04$ & 0.0027 \\
\hline
\end{tabular}


In relation to Individual polyunsaturated fatty acids $18: 2$ cis and 20:2 showed significant differences between treatments, with higher concentrations in pigs of T2. Despite of the fact that 18:2 trans was significant higher in T1, determinations were trace concentrations, tending to zero. Considering saturated individual fatty acids, 17:00 was higher in $T 1$, but no significant differences were found for the rest.

While no differences were found for MUFA:SFA ratio, T2 had a higher PUFA:SFA ratio. This treatment also had higher levels of $n-3$ and $n-6$ fatty acids, but a lower $n-6: n-3$ ratio.

\subsection{Behavioural observations}

General behaviour, as mean proportion of animals performing an specific activity in an observation period, is summarized in Table 4. Firstly, it can be observed that A did not differ between the different periods of the day in T1, while in T2 and $\mathrm{T} 2 \mathrm{~b}$ activity was higher in the morning and the afternoon in relation to midday, where it was reduced to the minimum. In addition, activity in those periods was significantly higher in $\mathrm{T} 2$ and $\mathrm{T} 2 \mathrm{~b}$ than in T1. Consequently, the opposite tendency was found for $P$. 
Table 4 - General behaviour of fattening pigs in T1, T2 and T2b, means \pm SD for Eating (EC), Drinking (D), Grazing (G), Walking

$(W)$, Exploring $(E)$, Hut $(H)$, Resting $(R)$, Mud resting $(M)$, Total resting (TR), Total active behaviour (A) and Total pasive behaviour $(\mathrm{P})$ in each observation period

\begin{tabular}{|c|c|c|c|c|c|c|c|c|c|c|}
\hline \multicolumn{3}{|c|}{ morning } & \multicolumn{4}{|c|}{ midday } & \multicolumn{2}{|c|}{ afternoon } & \multirow[b]{2}{*}{$\mathrm{T} 2 \mathrm{~B}$} & \multirow[b]{2}{*}{$\mathrm{p}$} \\
\hline & $\mathrm{T} 1$ & $\mathrm{~T} 2$ & $\mathrm{~T} 2 \mathrm{~B}$ & $\mathrm{~T} 1$ & $\mathrm{~T} 2$ & $\mathrm{~T} 2 \mathrm{~B}$ & $\mathrm{~T} 1$ & $\mathrm{~T} 2$ & & \\
\hline$\overline{\mathrm{G}}$ & -- & $0.25 \pm 0.15^{\mathrm{a}}$ & $0.21 \pm 0.18^{\mathrm{a}}$ & -- & $0.00 \pm 0.00^{b}$ & $0.00 \pm 0.00^{b}$ & -- & $0.22 \pm 0.15^{\mathrm{a}}$ & $0.17 \pm 0.16^{\mathrm{a}}$ & $<0.0001$ \\
\hline EC & $0.08 \pm 0.02^{\mathrm{a}}$ & $0.08 \pm 0.04^{\mathrm{a}}$ & $0.06 \pm 0.07^{\mathrm{a}}$ & $0.08 \pm 0.03^{\mathrm{a}}$ & $0.01 \pm 0.01^{b}$ & $0.00 \pm 0.01^{b}$ & $0.07 \pm 0.01^{a}$ & $0.12 \pm 0.04^{\mathrm{a}}$ & $0.10 \pm 0.06^{\mathrm{a}}$ & $<0.0001$ \\
\hline$D$ & $0.02 \pm 0.01 b^{c}$ & $0.01 \pm 0.01^{b c}$ & $0.04 \pm 0.03^{b}$ & $0.03 \pm 0.02^{b}$ & $0.01 \pm 0.01^{c}$ & $0.01 \pm 0.01^{c}$ & $0.02 \pm 0.01^{c}$ & $0.03 \pm 0.01^{b c}$ & $0.05 \pm 0.03^{\mathrm{a}}$ & $<0.0001$ \\
\hline W & $0.01 \pm 0.01^{b}$ & $0.06 \pm 0.04^{\mathrm{a}}$ & $0.05 \pm 0.05^{\mathrm{a}}$ & $0.01 \pm 0.01^{b}$ & $0.01 \pm 0.01^{b}$ & $0.01 \pm 0.01^{b}$ & $0.01 \pm 0.01^{b}$ & $0.05 \pm 0.03^{\mathrm{a}}$ & $0.04 \pm 0.04^{\mathrm{a}}$ & 0.0004 \\
\hline $\mathrm{E}$ & $0.15 \pm 0.05^{\mathrm{a}}$ & $0.13 \pm 0.10^{\mathrm{a}}$ & $0.11 \pm 0.08^{\mathrm{ab}}$ & $0.11 \pm 0.05^{\mathrm{ab}}$ & $0.01 \pm 0.02^{c}$ & $0.01 \pm 0.02^{c}$ & $0.10 \pm 0.05^{\mathrm{ab}}$ & $0.07 \pm 0.06^{b}$ & $0.09 \pm 0.08^{b}$ & 0.0012 \\
\hline $\mathrm{R}$ & $0.71 \pm 0.05^{c}$ & $0.17 \pm 0.17^{b}$ & $0.06 \pm 0.06^{\mathrm{a}}$ & $0.75 \pm 0.08^{c}$ & $0.06 \pm 0.06^{\mathrm{a}}$ & $0.06 \pm 0.06^{\mathrm{a}}$ & $0.78 \pm 0.06^{c}$ & $0.15 \pm 0.09^{b}$ & $0.12 \pm 0.10^{b}$ & 0.0011 \\
\hline $\mathrm{H}$ & -- & $0.28 \pm 0.19^{\mathrm{a}}$ & $0.42 \pm 0.23^{b}$ & -- & $0.90 \pm 0.08^{c}$ & $0.90 \pm 0.07^{c}$ & -- & $0.27 \pm 0.13^{\mathrm{a}}$ & $0.36 \pm 0.18^{b}$ & 0.004 \\
\hline$M$ & -- & $0.01 \pm 0.01$ & $0.01 \pm 0.02$ & -- & $0.01 \pm 0.01$ & $0.01 \pm 0.01$ & -- & $0.07 \pm 0.08$ & $0.04 \pm 0.04$ & \\
\hline TR & $0.71 \pm 0.05^{b}$ & $0.45 \pm 0.19^{\mathrm{a}}$ & $0.48 \pm 0.20^{\mathrm{a}}$ & $0.75 \pm 0.08^{b}$ & $0.96 \pm 0.04^{c}$ & $0.96 \pm 0.05^{c}$ & $0.78 \pm 0.06^{b}$ & $0.42 \pm 0.15^{\mathrm{a}}$ & $0.48 \pm 0.17^{\mathrm{a}}$ & $<0.0001$ \\
\hline A & $0.27 \pm 0.06^{b}$ & $0.54 \pm 0.19^{\mathrm{a}}$ & $0.51 \pm 0.20^{\mathrm{a}}$ & $0.23 \pm 0.07^{b}$ & $0.03 \pm 0.03^{c}$ & $0.03 \pm 0.03^{c}$ & $0.20 \pm 0.06^{b}$ & $0.50 \pm 0.17^{\mathrm{a}}$ & $0.48 \pm 0.17^{\mathrm{a}}$ & $<0.0001$ \\
\hline$P$ & $0.71 \pm 0.05^{b}$ & $0.46 \pm 0.19^{a}$ & $0.49 \pm 0.20^{\mathrm{a}}$ & $0.75 \pm 0.08^{b}$ & $0.97 \pm 0.03^{\mathrm{a}}$ & $0.97 \pm 0.03^{\mathrm{a}}$ & $0.78 \pm 0.06^{b}$ & $0.50 \pm 0.17^{\mathrm{a}}$ & $0.52 \pm 0.17^{\mathrm{a}}$ & $<0.0001$ \\
\hline
\end{tabular}

${ }^{\mathrm{abc}}$ values with similar letter in the row did not differ statistically $(\mathrm{p}<0.005)$ 
In general, statistically significant differences were present in each specific behaviour. EC showed similar results in all treatments during the morning and the afternoon, but this behaviour was drastically reduced in $\mathrm{T} 2$ and $\mathrm{T} 2 \mathrm{~b}$ during midday period and $W$ was higher in both outdoor treatments. At the same time, $G$ was similar in $\mathrm{T} 2$ and $\mathrm{T} 2 \mathrm{~b}$ in both morning and afternoon periods, and it did not appear in the midday period. Regarding the use of the huts, it was similar in T2 and T2b during the morning and the afternoon, and it was significantly increased in the midday period. In these treatments mud resting was also increased in the afternoon. In average, most of the animals of T1 were resting during the three periods, and TR was higher in T1 in relation to $\mathrm{T} 2$ and $\mathrm{T} 2 \mathrm{~b}$ except for midday period.

Agonistic behaviour (or aggressions) is presented in Table 5. Even though no significant difference was found for unidirectional $(p=0.1384)$ and total aggressions $(\mathrm{p}=0.0815)$, a marked tendency to increase aggressive behaviour was observed for confined animals as compared with pigs in outdoor system. In this way, reciprocal aggression and fighting resulted significantly higher in T1.

\begin{tabular}{|c|c|c|c|c|}
\hline Treatment & Unidirectional & Reciprocal & Fighting & Total aggression \\
\hline T1 & $7.8 \pm 5.9$ & $4.2 \pm 3.7$ & $0.6 \pm 1.2$ & $12.6 \pm 9.0$ \\
\hline $\mathrm{T} 2$ & $5.4 \pm 4.4$ & $2.3 \pm 2.2$ & $0.2 \pm 0.6$ & $7.9 \pm 5.8$ \\
\hline$p$ & 0.1384 & 0.0359 & 0.0017 & 0.0815 \\
\hline \multicolumn{5}{|l|}{ Period } \\
\hline AM & $5.1 \pm 4.7$ & $2.8 \pm 3.0$ & $0.3 \pm 0.7$ & $8.2 \pm 7.0$ \\
\hline PM & $8.1 \pm 5.6$ & $3.7 \pm 3.3$ & $0.5 \pm 1.1$ & $12.3 \pm 8.3$ \\
\hline$p$ & $<0.0001$ & 0.0110 & 0.1748 & $<0.0001$ \\
\hline
\end{tabular}


Regarding the pattern of aggressions along the day, they resulted higher in the afternoon than in the morning, although fighting was stable. This occurred mainly associated to an increase of agonistic behaviour during resting and exploration, as it can be appreciated in Table 6. When the total number of aggressions in active or passive activities is analyzed, it can be observed that in the afternoon, unidirectional aggressions are higher in passive behaviours, while reciprocal and fighting aggressions are mainly produced during active behaviours, being always higher in T1. In addition, aggressions while exploring ( $E$ in Table 6) showed significant differences between treatments regardless of the period, being always higher in T1. 


\begin{tabular}{|c|c|c|c|c|c|c|c|c|c|c|}
\hline & Act & 11 & 12 & $p$ & & 12 & p & $\mathrm{T} 1$ & T2 & $\mathrm{p}$ \\
\hline \multirow{10}{*}{$A M$} & $E C$ & $2.0 \pm 2.5$ & $0.9 \pm 2.0$ & 0.0506 & $0.7 \pm 1.3$ & $0.2 \pm 0.5$ & NS & $0.1 \pm 0.3$ & $0.0 \pm 0.0$ & NS \\
\hline & D & $0.4 \pm 0.8$ & $0.6 \pm 1.1$ & NS & $0.4 \pm 1.0$ & $0.5 \pm 1.0$ & NS & $0.0 \pm 0.0$ & $0.1 \pm 0.3$ & 0.0571 \\
\hline & $E$ & $1.1 \pm 1.7$ & $0.8 \pm 1.9$ & NS & $1.6 \pm 2.3$ & $0.2 \pm 0.8$ & 0.0001 & $0.2 \pm$ & $0.0 \pm 0.2$ & 0.0352 \\
\hline & $R$ & $1.9 \pm 2.1$ & $1.7 \pm 2.6$ & NS & $0.9 \pm 1.3$ & $0.9 \pm 1.0$ & NS & $0.1 \pm 0.5$ & $0.2 \pm$ & NS \\
\hline & G & --- & $0.0 \pm 0.0$ & --- & --- & $0.0 \pm 0.0$ & --- & -- & $0.0 \pm 0.0$ & --- \\
\hline & M & --- & $0.4 \pm 0.8$ & --- & -- & $0.1 \pm 0.4$ & -- & --- & $0.0 \pm 0.2$ & --- \\
\hline & 0 & $0.4 \pm 1.1$ & $0.1 \pm 0.3$ & NS & $0.1 \pm 0.0$ & $0.0 \pm 0.3$ & NS & $0.0 \pm 0.0$ & $0.0 \pm 0.0$ & NS \\
\hline & A & $3.9 \pm 3.8$ & $2.3 \pm 3.1$ & NS & $2.8 \pm 3.3$ & $1.0 \pm 1.6$ & 0.0090 & $0.3 \pm 0.6$ & $0.1 \pm 0.3$ & NS \\
\hline & $P$ & $1.9 \pm 2.6$ & $2.1 \pm 2.3$ & NS & $0.9 \pm 1.3$ & $1.0 \pm 1.0$ & NS & $0.1 \pm 0.3$ & $0.2 \pm 0.6$ & NS \\
\hline & Tot. & $5.8 \pm 5.4$ & $4.4 \pm 3.8$ & NS & $3.7 \pm 3.6$ & $1.9 \pm 1.8$ & NS & $0.4 \pm 0.7$ & $0.3 \pm 0.7$ & NS \\
\hline \multirow{10}{*}{ PM } & EC & $2.5 \pm 3.1$ & $3.0 \pm 4.6$ & NS & $1.8 \pm 2.2$ & $1.0 \pm 1.5$ & 0.0529 & $0.1 \pm 0.3$ & $0.0 \pm 0.0$ & 0.0082 \\
\hline & D & $1.4 \pm 3.1$ & $0.8 \pm 1.3$ & NS & $0.4 \pm 0.7$ & $0.4 \pm 0.9$ & 0.7466 & $0.0 \pm 0.2$ & $0.0 \pm 0.0$ & NS \\
\hline & $E$ & $2.5 \pm 2.3$ & $0.2 \pm 0.5$ & $<0.0001$ & $1.3 \pm 1.9$ & $0.1 \pm 0.4$ & 0.0007 & $0.5 \pm 1.2$ & $0.0 \pm 0.0$ & $<0.0001$ \\
\hline & $\mathrm{R}$ & $2.6 \pm 1.8$ & $0.8 \pm 1.2$ & 0.0003 & $1.0 \pm 1.2$ & $0.4 \pm 0.9$ & NS & $0.1 \pm 0.3$ & $0.1 \pm 0.3$ & NS \\
\hline & G & --- & $1.3 \pm 2.1$ & --- & --- & $0.7 \pm 1.4$ & -- & --- & $0.0 \pm 0.2$ & --- \\
\hline & $M$ & --- & $0.4 \pm 0.7$ & --- & --- & $0.1 \pm 0.5$ & --- & --- & $0.0 \pm 0.2$ & --- \\
\hline & 0 & $0.8 \pm 1.5$ & $0.0 \pm 0.0$ & 0.0004 & $0.3 \pm 0.5$ & $0.0 \pm 0.0$ & 0.0082 & $0.1 \pm 0.3$ & $0.0 \pm 0.0$ & 0.0198 \\
\hline & A & $7.2 \pm 5.5$ & $5.3 \pm 4.9$ & NS & $3.7 \pm 3.3$ & $2.2 \pm 2.3$ & 0.0390 & $0.8 \pm 1.4$ & $0.0 \pm 0.2$ & $<0.0001$ \\
\hline & $P$ & $2.6 \pm 1.8$ & $1.1 \pm 1.6$ & 0.0007 & $1.0 \pm 1.2$ & $0.5 \pm 0.9$ & NS & $0.1 \pm 0.3$ & $0.1 \pm 0.3$ & NS \\
\hline & Tot. & $9.8 \pm 5.9$ & $6.4 \pm 4.8$ & 0.0584 & $4.7 \pm 3.7$ & $2.7 \pm 2.5$ & 0.0477 & $0.9 \pm 1.5$ & $0.1 \pm 0.3$ & 0.0001 \\
\hline
\end{tabular}




\subsection{Physiological parameters}

Table 6 shows the results of the physiological parameters assessed in this experiment. As it is displayed, significant differences between T1 and T2 were detected in serum cortisol concentration and it level were higher in T1 in the two samplings.

Table 7 - Cortisol serum concentration $(\mathrm{ng} / \mathrm{mL})$ for pigs reared in three different production systems: $\mathrm{T} 1, \mathrm{~T} 2$ and $\mathrm{T} 2 \mathrm{~b}$ sampled at the day 84 the experiment (sample 1 ) and at slaughter house (sample 2 ).

\begin{tabular}{cccccccc}
\hline Treatment & \multicolumn{1}{c}{ T1 } & \multicolumn{2}{c}{ T2 } & \multicolumn{2}{c}{ T2b } & p \\
\hline & range & mean & range & mean & range & mean & \\
\hline Day 84 & $6.8-7.7$ & $6.6 a$ & $5.5-6.2$ & $5.0 \mathrm{~b}$ & $4.6-5.2$ & $4.1 \mathrm{c}$ & $<0.001$ \\
Slaughterhouse & $15.7-17.8$ & $15.9 \mathrm{a}$ & $12.3-14.1$ & $13.0 \mathrm{~b}$ & & --- & $<0.001$ \\
\hline $\mathrm{P}$ & $<0.001$ & $<0.001$ & & & \\
\hline
\end{tabular}

${ }^{a b c}$ Means within the same row with no common superscript $(P<0.05)$.

For the ranges: Upper limit $=\operatorname{lnv}\left(\mu_{\ln [\text { cortisol] }}+S E_{\ln [\text { cortisol concentration] })}\right)$ Lower limit $=\operatorname{lnv}\left(\mu_{\ln [\text { cortisol }}\right.$ concentration) $-\mathrm{SE} \operatorname{In}[$ cortisol concentration] $)$

As regards to the biochemical profile, most of the parameters analysed were inside the reference ranges, except ALT, CHOL and GGT which are over the limits in all the treatments, and TBIL for T2b and TP for T1 and T2. In general, there is not a clear pattern although treatment T2b presented lower values of ALB, BUN, CHOL, Phos and TP, while T2 resulted in a higher activity of GGT and GLU in blood serum was higher in $\mathrm{T} 1$ than in the other treatments. 
Ethologic, physiologic and meat characterization of pig production systems

\begin{tabular}{|c|c|c|c|c|c|c|}
\hline \multicolumn{7}{|c|}{ systems: $\mathrm{T} 1$ and $\mathrm{T} 2$ (means $\pm \mathrm{SD}$ ) } \\
\hline & $\mathrm{T} 1$ & $\mathrm{~T} 2$ & $\mathrm{~T} 2 \mathrm{~b}$ & $\mathrm{p}$ & Reference & Units \\
\hline ALB & $2.9 \pm 0.6^{\mathrm{a}}$ & $3.6 \pm 1.2^{\mathrm{a}}$ & $2.0 \pm 1.0^{b}$ & $<0.0001$ & $1.8-33$ & $\overline{g / d L}$ \\
\hline ALKP & $146.5 \pm 23.8$ & $164.9 \pm 37.3$ & $153.6 \pm 98.0$ & NS & $92-294$ & IU \\
\hline ALT & $122.6 \pm 13.9$ & $117.2 \pm 16.9$ & $113.0 \pm 38.4$ & NS & $9-43$ & IU \\
\hline Amyl & $812.1 \pm 161.7$ & $711.9 \pm 160.1$ & $749.1 \pm 331.0$ & NS & $271-1198$ & IU \\
\hline BUN & $13.1 \pm 3.2^{\mathrm{a}}$ & $13.9 \pm 3.1^{\mathrm{a}}$ & $10.7 \pm 2.8^{b}$ & 0.0022 & $6-30$ & $\mathrm{mg} / \mathrm{dL}$ \\
\hline $\mathrm{Ca}$ & $13.8 \pm 1.4$ & $13.2 \pm 1.9$ & $13.2 \pm 4.7$ & NS & $6.5-11.4$ & $\mathrm{mg} / \mathrm{dL}$ \\
\hline $\mathrm{CHOL}$ & $110.4 \pm 28.7^{b}$ & $103.9 \pm 34.1^{b}$ & $38.3 \pm 35.0^{\mathrm{a}}$ & $<0.0001$ & $18-79$ & $\mathrm{mg} / \mathrm{dL}$ \\
\hline CK & $941.1 \pm 523.8$ & $1199.5 \pm 1304.3$ & $1299.3 \pm 1705.3$ & NS & $50-3531$ & IU \\
\hline CREA & $1.8 \pm 0.3$ & $1.8 \pm 1.0$ & $1.8 \pm 0.5$ & NS & $0.5-2.1$ & $\mathrm{mg} / \mathrm{dL}$ \\
\hline GGT & $49.8 \pm 19.5^{\mathrm{a}}$ & $63.7 \pm 21.3^{b}$ & $48.7 \pm 27.6^{\mathrm{a}}$ & 0.0327 & $16-30$ & IU \\
\hline GLU & $150.6 \pm 12.4^{\mathrm{a}}$ & $123.1 \pm 27.2^{b}$ & $108.4 \pm 28.9^{b}$ & $<0.0001$ & $85-160$ & $\mathrm{mg} / \mathrm{dL}$ \\
\hline Phos & $9.2 \pm 1.0^{\mathrm{a}}$ & $9.2 \pm 1.2^{a}$ & $5.2 \pm 1.7^{b}$ & $<0.0001$ & 3.6-9.2 & $\mathrm{mg} / \mathrm{dL}$ \\
\hline TBIL & $0.3 \pm 0.00^{b}$ & $0.2 \pm 0.04^{c}$ & $0.4 \pm 0.1^{a}$ & $<0.0001$ & $0.1-0.3$ & $\mathrm{mg} / \mathrm{dL}$ \\
\hline TP & $8.4 \pm 0.9^{a}$ & $8.2 \pm 1.2^{\mathrm{a}}$ & $7.2 \pm 2.4^{b}$ & 0.0036 & $6.0-8.0$ & $\mathrm{~g} / \mathrm{dL}$ \\
\hline
\end{tabular}

abc values with similar letter in the row did not differ statistically $(p<0.005) *($ Idexx, 2006)

\section{Discussion}

\subsection{Production, carcass and meat measures}

Productive results showed differences between systems not only referred to economic interests as growing rates, but also in characteristics linked to the product quality. The reduction in growing rates in outdoor pigs is probably caused by the exercise, which has an extra energy cost (Edwards, 2005), as it was hypothesized by Hansen et al. (2006) and Bee et al. (2004), although they remarked that it is not possible to separate the effect of increased activity and the 
effect of the environment in outdoor systems. Regarding to this, general live weight evolution was strongly marked for the drastic reduction of weight gain in T2 for the third week. In this week, several days of cold and hard wind, affected outdoor animals causing a deficient growing response. Long exposures to cold temperatures produced adaptation of pigs reducing energy losses and adjusting intake (Demo et al., 1995; Macari et al., 1986), but when low temperatures occur suddenly or cyclically it affects animals more severely (Nienaber et al., 1989;. Geers et al., 1987). In extreme cold conditions, López et al. (1991) reported even that pigs housed between -5 and $8^{\circ} \mathrm{C}$ ate less feed, grew more slowly and had a worse feed conversion ratio than those housed at $20^{\circ} \mathrm{C}$.

In practical conditions, it is difficult to control the environment in outdoor systems, so the animals are exposed to climatic variations. Nevertheless, they try to cope with these circumstances, looking for accommodation in refuges, shade, mud, etc, in order to reach comfortable conditions as described by Olsen et al. (2001). These alternatives are probably more favourable in hot than in cold weather.

Another point to consider in order to explain the low and decreasing growing rate in the period for T2b could be the different stadium of the growing curve of these animals, due to the different age of the animals.

Regarding to carcass and meat quality, results were according to the expected in relation to the experience with grazing pigs (Echenique et al., 2009b). As it was shown, differences between treatments were concentrated in two characteristics: dorsal fat thickness and lightness of the meat. The reduction of back fat deposition as a consequence of the exercise in outdoor systems, is widely reported, (e.g.; Basso et al., 2006; Coyne, 2000; Enfält et al., 1997; Gnanaraj et al., 
2002). Pasture intake can also affect food digestion and the metabolizing of total diet (Hansen et al., 2006), but in the present study it is not possible to separate this effect from the global effect of the system. However, other authors did not find any difference in fat deposition between systems with outdoor access including or not pasture (Braun and Cervellini, 2004; Daza et al., 2009; Gondret et al., 2005; Hale et al., 1986; Högberg et al., 2004; Morrison et al., 2007). On the contrary, the enrichment of environment could improve growth rate and back fat (Beattie et al., 2000). In this direction, Gentry et al.(2002) found that pigs fed outdoor in Texas during summer were fatter than indoor fed pigs. Pugliese et al. (2005) also found more fat deposition in pigs reared in woodlands pastures in comparison with indoor reared pigs, but in this case outdoor animals were slaughtered 200 days later than indoor pigs, which could modify physiology and tissue deposition.

Considering physic properties of meat, $\mathrm{pH}$ values were into the expectable range, being similar to those reported by other authors (Gentry et al., 2002; Echenique et al,2009b; Barloco et al., 2010; Lebret et al., 2006; Terlouw et al., 2009), who did not find differences between pigs in outdoor or indoor systems, even when animals had access to pastures. However, pigs reared outdoor on pasture, have shown a decrease in ultimate $\mathrm{pH}$ in different muscles of the ham (Enfält et al., 1997; Bee et al., 2004). Ultimate muscle $\mathrm{pH}$ is determined by glycogen content at slaughter (Bendall and Swatland, 1988) and, in this case, pH24 did not differ, so this aspect is probably not affecting meat in both systems. Meat colour showed lower L parameter in T2, which is a desirable characteristic for reducing paleness of meat. This result is consistent with Bee et al. (2004) and Pugliese et al. (2005), although other studies did not find differences in this parameter (Gentry et al., 2002; Lebret and Guillard, 2005; Lebret et al., 2006). Meat colour and water- 
holding capacity are affected by biochemical processes during the post-slaughter conversion of muscle to meat, and low ultimate $\mathrm{pH}$ is associated with drip loss (Bee et al., 2004). Pale, soft and exudative (PSE) meat generally has less appeal to consumers and meat processors than pink pork with a somewhat firm texture and little or no evidence of fluid loss (Bendall and Swatland, 1988). Based on colour and $\mathrm{pH}$ results, it is possible to infer that in both systems meat is acceptable, with a little better colour in $\mathrm{T} 2$ pigs.

Regarding nutritional quality, the fatty acid composition of meat receives a lot of attention in research because of its implications for human health (Raes et al., 2004). For this reason, differences on lipid profile of the two production systems have to be considered as relevant results.

Higher PUFA contents of the fat in T2 animals could be a consequence of including pasture in the diet and they are consistent with the results obtained by Hansen et al. (2006), Daza et al. (2009) and Bee et al. (2004). Pasture is an important unsaturated fatty acids source, especially for linolenic acid (Woods and Fearon, 2009). However, they did not consider this source for pig nutrition, although they include algae. This is due to the fact that pigs, unlike ruminants, are generally fed with high concentrate diets and without forages (Raes et al., 2004).

Pigs from T2 had higher concentration of linoleic (18:2), linolenic (18:3) and eicosadienoic (20:2), being the first two the most relevant, from nutritional point of view. Higher levels of 18:3 are reported for pigs reared in systems with pastures in comparison with traditional concentrated diets (Moisá et al., 2007; Lebret and Guillard, 2005; Pugliese et al., 2005; Nilzén et al., 2001), organic system with clover silage (Hansen et al., 2006) or with addition of algae to diet (Sardi et al., 2006). From a nutritional point of view, higher concentration of MUFA and PUFA 
and low n-6:n-3 are associated with good quality (Capra et al, 2007). However, higher concentrations of polyunsaturated fatty acids may cause technological problems to industry in the elaboration of certain products, due to their susceptibility to oxidation (Isabel et al., 2003; Ruíz and López-Bote, 2005).

Higher contents of MUFA in T1 are explained by 18:1 fatty acid concentration, but this result is of equivocal interpretation. Unsaturated fatty acids concentration in pigs fat is associated to its concentration in the diet (Raes et al., 2004). As a consequence, MUFA should be similar or higher in T2 due to pasture intake. Hansen et al. (2006) found higher MUFA in pigs fed with $100 \%$ concentrate diet as compared with pigs fed with $70 \%$ concentrate and $30 \%$ clover or barley silage, but these authors did not discuss this result. Daza et al. (2009) comparing pigs produced in free-range system and confined (sedentary), obtained higher concentrations of MUFA in free range pigs, attributing these results to the effect of exercise. This finding also contrasts with the present work, were higher fat contents of MUFA were obtained in T2 (more exercised animals). This result can be interpreted by the fact that pigs in T2, which had less total fat than in T1 according to dorsal fat thickness, had an increase in the proportion of unsaturated by decreasing the saturated fatty acids deposition as concluded by Hansen et al. (2006). Considering saturation ratios, only PUFA:SFA ratio showed differences between treatments, being higher in T2 influenced for the higher contents of PUFA. For this parameter, Warnats et al. (1998) recommend ratios above 0.45 which is the case of T2in the present work. A lower n-6:n-3 fatty acids ratio was observed for T2 which is consistent with findings of Capra et al (2011) who observed the lowest $n-6: n-3$ ratio for fattening pigs with access to pasture in comparison with other concentrated based treatments. For Iberian pigs, Daza et al (2007) determined a lower $n-6: n-3$ ratio in free range system in comparison 
with animal confined and fed with a concentrate diet. Absolute values obtained in the present study were higher that those reported by those authors, but probably exist a genetic component as was demonstrated by Estévez et al (2004) who found significant differences between Iberian and White pigs, averaging 9,67 and 16.64 respectively, being this last value very similar to our results. Although is not possible isolate other effects like exercise of animals, is reasonable to think that the pasture intake was enough to reduce $n-6: n-3$ ratio by increasing $n-3$ fatty acids content in $T 2$ animals, although $n-6$ fatty acids were also higher, considering that pasture is an important source of $n-3$ fatty acids (Woods and Fearon, 2009) and affect n-3 fatty acids composition of tissues in pigs (Raes et al, 2004).

\subsection{Behavioural observation}

General activity, assessed in the present study as means of animals performing an active behaviour, is commonly reported as increasing in outdoor reared pigs, and in intensive farming systems they remain most of the time physically inactive, as they spend their whole life confined in high density pens (Daza et al., 2009). Our results confirm this tendency of increasing activity in outdoor system, which was previously observed by Terlouw et al. (2009); Hotzel et al. (2004) and Guy et al. (2002) among others. Space availability appears as a reason to explain this behaviour, but some other factors are probably contributing. Although there is an overall decrease in the percentage of time spent sitting and lying when increasing space allowance per pig, it exists a non-linear relationship between the space allowance per pig and these behaviours (Averós et al., 2010). In this direction, increasing total activity and consequently low resting behaviour have been found as useful to compare barren with enriched environments (Guy et al., 2002; Bolhuis et al., 2005; Cagienard et al., 2005). The evidence indicates that a 
combination of the characteristics of outdoor systems, such as space allowance, possibilities of exploring or rooting, contribute to stimulate pigs activity.

To the best of our knowledge, the fact that pigs in T1 apparently have a continuous rhythm along the day, being pigs active in the same proportion for the three periods assesed, is an interesting finding. Conversely, activity in T2 and T2b was very low at midday, while it was increased in the morning and the afternoon. Something similar was reported by Villagrá et al. (2007) who found that pigs in multi-activity pens were active mainly during the light hours, and the activities were clearly bimodal with peaks in the morning and in the afternoon. The ethogram for domestic free-ranging pigs has been found to be similar to the wild boar (Stolba and Wood-Gush, 1981) and in outdoor systems animals are likely to have a more natural circadian behaviour. For example, Iberian pigs in extensive conditions are more likely to cope with their environment and to perform normal patterns of behaviours (Temple et al., 2011). Nevertheless, in the present work, the activity pattern is also strongly influenced by sun incidence. Regarding to this, in midday hours all animals looked for a shade inside or next to the hut, and the exposed to sun only inisolated activities like drinking, eating concentrate or mud bath. One of the questioned aspects of rearing white pigs in outdoor system, is the sunlight sensibility of the skin, but animals can learn rapidly how to protect themselves, adapting their behaviour to the different moments of the day or covering their skin with mud.

Regarding individual active activities, grazing and exploring were the most frequent, although grazing only was possible in $\mathrm{T} 2$ and $\mathrm{T} 2 \mathrm{~b}$ and time destined to it was similar to the time destined to total active behaviour in T1 for the periods of morning and afternoon. Rodríguez-Estévez et al. (2009) reported a high time destined to foraging in a dehesa system (45\% of daylight hours) although dehesa's 
conditions are different to those in the present study, with lower availability of foraging resources. The motivation to forage, whether by grazing or by rooting, is not only influenced by external stimuli, earlier experience and hunger, but also by factors such as biologically determined time-budgets, and it can be changed by herbage availability (Andresen and Redbo, 1999). In our experiment, the high amount of time destined to $G$ could be caused by the low forage offer due to drought, as presented in chapter 4 . Nevertheless, it also could be an extension of exploratory behaviour.

In T1, exploring behaviour did not differ from $\mathrm{T} 2$ or $\mathrm{T} 2 \mathrm{~b}$ in the morning or in the afternoon, which is coincident with findings of Temple et al. (2011) who did not find differences in the expression of exploratory behaviour between extensive and intensive reared Iberian pigs, although as it was said previously, part of the time destined to $\mathrm{G}$ behaviour is probably an exploratory behaviour.

Considering agonistic behaviour, T1 showed a general tendency to increase reciprocal aggressive interactions along the day and fighting, although the unidirectional ones were no significant. Intensive rearing conditions tend to foment competition for resources between pigs increasing the occurrence and duration of negative social interactions (Temple et al., 2011). Groups kept in a closed space; where the individuals are not able to withdraw from the group, and resources of environment are limited and defensible promote aggression and social stress (Andersen et al., 2004). Space allowance is one of the possible causes, because when fight occurs there are less possibilities of showing submission behaviour (Gonyou, 2001). In addition to higher space allowance, T2 had a very enriched environment which contributed to the reduction of agonistic behavior, as it was reported by several authors (van de Weerd and Day, 2009; Beattie et al., 2000; O'Connell and Beattie, 1999; Schaefer et al., 1990; Weerd et 
al., 2006; Morrison et al., 2007). Some specific aspects such as the higher aggression in T1 while exploring behaviour, lead to the thought that there is an important effect of barren ambient in the increase of aggressions. In this direction, it was possible to observe a kind of competence for exploring a few square centimeters of floor, when an individual detect a place of it interest. A reduction of negative social behaviour was found by Averós et al. (2010) and Jensen and Pedersen, (2010) providing bedding or rooting materials in order to increase exploration possibilities. Unidirectional and reciprocal aggressions increased in the afternoon, which is a clear hotter period. This showed an influence of discomfort in agonistic behaviour, furthermore the barren environment.

\subsection{Physiological parameters}

Significant higher serum cortisol concentration in T1 was expectable, as reflect of possible stressful conditions in indoor pigs, although the low concentration values in all treatments make us to be careful when interpreting the real biological meaning of this difference. Cortisol is not necessarily the response to a stressful stimulus, but can also reflect their involvement in homeostatic metabolic processes, being an example the increase levels induced by meals (Mormède et al., 2007). In the blood sample taken at slaughterhouse, after transport and lairage, cortisol levels increased in both $\mathrm{T} 1$ and $\mathrm{T} 2$, but significant differences were maintained between them. Cortisol concentration has been shown to increase in response to acute stressors like transport (Hicks et al., 1998; Warriss, 1998; Chai et al., 2010), mixing (Death et al., 2010; Morrow-Tesch et al., 1994) or castration (Prunier et al., 2005). However, there are no evidences of differences between traditional and enriched systems in cortisol concentration during rearing or their effects in transport and lairage. No differences were found in blood cortisol 
concentration for pigs reared in outdoor and indoor systems (Rudine et al., 2007), or between both plasma and urine cortisol after transport and lairage for pigs reared in outdoor and indoor conventional system (Lebret et al., 2006). Similar results are reported by (Barton Gade, 2008) for free range and conventional raised pigs. However, the upholding of the differences showed at the farm between T1 and T2 after transport, as well as the higher level of aggression in T1 and the higher level of glucose, could be an evidence of distress in pigs under this treatment.

Most of the biochemical parameters analyzed were inside the reference values, except for ALT, CHOL and GGT (related to hepatic function distortion, Idexx, 2006), but animals did not show any symptoms, and they had a normal growing rate. The high level of $\mathrm{CHOL}$ could be caused by some component of the concentrate which made difficult the liver activity. A decrease in serum of GGT, has been previously reported when Deoxinivalenol (DON) contaminated maize was fed to growing pigs (Döll et al., 2005). DON presence in the concentrate could be possible as well as other micotoxins, as the diet included maize, but they were not analyzed and growing rates did not evidence this kind of toxicity.

Glucose concentration in blood serum was higher in T1, and according to Fernandez et al. (1994), it can be explained by the increasing of aggressive behaviour of pigs as is was presented in tables 4 and 5. Puppe et al., (1997) also found that levels of glucose increased in piglets with increasing stress and Barnett et al. (1983) found elevated levels of plasma glucose as a response of stress in gilts. In addition, Hale et al. (1986) found lower glucose levels associated with exercised pigs and diets with a low energy level, which could be a similar situation to the present in $\mathrm{T} 2$ and $\mathrm{T} 2 \mathrm{~b}$, with reduced glucose levels. 


\section{Conclusions}

Both production systems reach an acceptable productive performance, with no relevant health problems detected. Differences in meat characteristics between both systems suggest that they might be favourable or not, depending on final destination of meat. For fresh consume the higher concentration of polyunsaturated fatty acids improve nutritional value, but this characteristic become meat more susceptible to oxidation, not suitable for industry. Animals in outdoor systems are in general more active and have a non stable daily pattern of behaviour, whereas indoor pigs are more sedentary and have a more stable behaviour pattern along the day. The increase of reciprocal aggressions and fight, cortisol and glucose in T1, could be evidencing some welfare problems in pigs reared in indoor conventional system in comparison with outdoor systems.

\section{References}

Andersen, I. L., Nmvdal, E., Bakken, M. and Bóe, K. E. (2004). Aggression and group size in domesticated pigs, Sus scrofa: ['] when the winner takes it all and the loser is standing small'. Animal Behaviour 68(4), 965-975.

Andresen, N. and Redbo, I. (1999). Foraging behaviour of growing pigs on grassland in relation to stocking rate and feed crude protein level. Applied Animal Behaviour Science 62[2-3], 183-197.

Aparicio Tovar, M. A. and Vargas Giraldo, J. D. (2006). Considerations on ethics and animal welfare in extensive pig production: Breeding and fattening Iberian pigs. Livestock Science 103(3), 237-242.

Averós, X., Brossard, L., Dourmad, J. Y., de Greef, K. H., Edge, H. L., Edwards, S. A. and Meunier-Salaün, M. C. (2010). A meta-analysis of the combined effect of 
housing and environmental enrichment characteristics on the behaviour and performance of pigs. Applied Animal Behaviour Science 127(3-4), 73-85.

Barloco, N., Vadel, A. and Mondelli, M. (2010). Efecto del suministro restringido de concentrado y acceso permanente a pasturas cultivadas en cerdos en crecimiento-engorde. 2. Facultad de Agronomía. Montevideo.

Barloco, N. (2007). Recría y terminación de cerdos en condiciones pastoriles. IX Encuentro de Nutrición y Producción en Animales Monogástricos, 87-94. Montevideo, UDELAR, INIA.

Barnett, J. L., Cronin, G. M., McCallum, T. H. and Newman, E. A. (1993). Effects of pen size/shape and design on aggression when grouping unfamiliar adult pigs. Applied Animal Behaviour Science 36(2-3), 111-122.

Barnett, J. L., Cronin, G. M., McCallum, T. H., Newman, E. A. and Hennessy, D. P. (1996). Effects of grouping unfamiliar adult pigs after dark, after treatment with amperozide and by using pens with stalls, on aggression, skin lesions and plasma cortisol concentrations. Applied Animal Behaviour Science 50(2), 121133.

Barnett, J. L., Hemsworth, P. H. and Hand, A. M. (1983). Effects of chronic stress on some blood parameters in the pig. Applied Animal Ethology 9(3-4), 273-277.

Barnett, J. L. (2007). Effects of confinement and research needs to underpin welfare standards. Journal of Veterinary Behavior: Clinical Applications and Research 2(6), 213-218.

Barton Gade, P. (2008). Effect of rearing system and mixing at loading on transport and lairage behaviour and meat quality: Comparison of free range and conventionally raised pigs. Animal 2(8), 1238-1246. 
Basso, L., Campagna, D., Brunori, J., Alleva, G., Silva, P., Franco, R. and Somenzini, D. (2006). Recría-terminación de cerdos al aire libre o en confinamiento: su influencia en los cortes comerciales de la res. Memorias VIII Congreso Nacional de Producción Porcina. Cordoba.

Baumgartner, J., Laister, S., Koller, M., Pfützner, A., Grodzycki, M., Andrews, S. and Schmoll, F. (2010). The behaviour of male fattening pigs following either surgical castration or vaccination with a GnRF vaccine. Applied Animal Behaviour Science 124(1-2), 28-34.

Beattie, V. E., O'Connell, N. E. and Moss, B. W. (2000). Influence of environmental enrichment on the behaviour, performance and meat quality of domestic pigs. Livestock Production Science 65(1-2), 71-79.

Beattie, V. E., Walker, N. and Sneddon, I. A. (1995). Effect of rearing environment and change of environment on the behaviour of gilts. Applied Animal Behaviour Science 46(1-2), 57-65.

Bee, G., Guex, G. and Herzog, W. (2004). Free-range rearing of pigs during the winter: Adaptations in muscle fiber characteristics and effects on adipose tissue composition and meat quality traits. Journal of Animal Science 82(4), 12061218.

Bendall, J. R. and Swatland, H. J. (1988). A review of the relationships of $\mathrm{pH}$ with physical aspects of pork quality. Meat Science 24(2), 85-126.

Bolhuis, J. E., Schouten, W. G. P., Schrama, J. W. and Wiegant, V. M. (2005). Behavioural development of pigs with different coping characteristics in barren and substrate-enriched housing conditions. Applied Animal Behaviour Science 93(3-4), 213-228. 
Braun, R. O. and Cervellini, J. E. (2004). El confinamiento como causal de estrés en cerdos. Calidad de la res. IIReunión Binacional de Ecología, XI reunión de la Sociedad de Ecología de Chile y XXI Reunión Argentina de Ecología. Mendoza.

Cagienard, A., Regula, G. and Danuser, J. (2005). The impact of different housing systems on health and welfare of grower and finisher pigs in Switzerland. Preventive Veterinary Medicine 68(1), 49-61.

Canfield, K. (2006). Pork production in Latin America: Processing sector., Volume 2 Spring issue, 2006. The Profit Improver, 2(spring issue).

Capra, G., Echenique, A., Grompone, M. A., Bauzá, R., González, A. and Silva, D. (2007). Evaluación de la inclusión de grano de soja desactivado, afrechillo de arroz integral o suero de quesoen la dieta de cerdos en engorde. Agrociencia IX, 59-63.

Capra, G., Repiso, L., Fradilettti, F., Martínez, R., Cozzano, S. and Márquez, R. (2011). Efecto de la dieta de cerdos en crecimiento sobre el valor nutritivo y aptitud tecnológica de la carne y grasa. INNOTEC 6 (in press).

Chai, J., Xiong, Q., Zhang, C. X., Miao, W., Li, F. E., Zheng, R., Peng, J. and Jiang, S. W. (2010). Effect of pre-slaughter transport plant on blood constituents and meat quality in halothane genotype of NN Large Whiteálálandrace pigs. Livestock Science 127(2-3), 211-217.

Coyne, M. (2000). Microbiología del Suelo . Un Enfoque Exploratorio., Paraninfo S.A.,. pp. $1-440$.

Dawkins, M. S. (2004). Using behaviour to assess animal welfare. Animal Welfare 13, S3-S7. 
Daza, A., Mateos, A., Rey, A. I., Ovejero, I. and López-Bote, C. J. (2007). Effect of duration of feeding under free-range conditions on production results and carcass and fat quality in Iberian pigs. Meat Science 76(3), 411-416.

Daza, A., Rey, A. I., Olivares, A., Cordero, G., Toldrá, F. and López-Bote, C. J. (2009). Physical activity-induced alterations on tissue lipid composition and lipid metabolism in fattening pigs. Meat Science 81(4), 641-646.

de Jonge, F. H., Bokkers, E. A. M., Schouten, W. G. P. and Helmond, F. A. (1996). Rearing piglets in a poor environment: Developmental aspects of social stress in pigs. Physiology \& Behavior 60(2), 389-396.

Death, R. B., Turner, S. P., Kurt, E., Evans, G., Thálking, L., Looft, H., Wimmers, K., Murani, E., Klont, R., Foury, A., Ison, S. H., Lawrence, A. B. and Mormède, P. (2010). Pigs' aggressive temperament affects pre-slaughter mixing aggression, stress and meat quality. Animal 4(4), 604-616.

Deen, J. (2010). Pigs: Behavior and Welfare Assessment. Edición: Michael, D. Breed y Janice, Moore. En: Encyclopedia of Animal Behavior. Pag. 731-739. Oxford, Academic Press.

Demo, M., Jentsch, W. and Hoffmann, L. (1995). Effect of long time exposure to different environmental temperatures on heat production of growing pigs. Livestock Production Science 43(2), 149-152.

DIEA. (2007). Encuesta Porcina 2006. Caracterización de la situación productiva, tecnológica, comercial y social del sector porcino. FPTA, MGAP-INIA, 170, pp. 1-71. Montevideo.

DIEA. (2010). Anuario Estadístico 2010. MGAP. Montevideo. 
Docking, C. M., van de Weerd, H. A., Day, J. E. L. and Edwards, S. A. (2008). The influence of age on the use of potential enrichment objects and synchronisation of behaviour of pigs. Applied Animal Behaviour Science 110(3-4), 244-257.

Döll, S., Gericke, S., Dänicke, S., Raila, J., Ueberschör, K. H., Valenta, H., Schnurrbusch, U., Schweigert, F. J. and Flachowsky, G. (2005). The efficacy of a modified aluminosilicate as a detoxifying agent in Fusarium toxin contaminated maize containing diets for piglets. Journal of Animal Physiology and Animal Nutrition 89(9-10), 342-358.

Echenique, A., Repiso, L., and Capra, G. (2009a). Composición química y calidad sensorial de jamones curados provenientes de cerdos alimentados con una dieta rica en ácido oleico y pasturas. INNOTEC 4. Montevideo, LATU.

Echenique, A.; Capra, G.; Pardo, G.; Grompone, M. A. and Urruzola, N. (2009b) Efecto de las pasturas sobre la composición química de la grasa intramuscular de cerdos machos enteros y castrados producidos al aire libre en Uruguay. AIDA (2009) XIII Jornadas sobre producción animal. (II). 622-624

Edwards, S. A. (2005). Product quality attributes associated with outdoor pig production. Livestock Production Science 94(1-2), 5-14.

Enfält, A. C., Lundström, K., Hansson, I., Lundeheim, N. and Nyström, P. E. (1997). Effects of outdoor rearing and sire breed (Duroc or Yorkshire) on carcass composition and sensory and technological meat quality. Meat Science 45(1), 1-15.

Estévez, M., Morcuende, D., Ramírez, R., Ventanas, J. and Cava, R. (2004). Extensively reared Iberian pigs versus intensively reared white pigs for the manufacture of liver pâté. Meat Science 67(3), 453-461. 
Ewbank, R. and Bryant, M. J. (1972). Aggressive behaviour amongst groups of domesticated pigs kept at various stocking rates. Animal Behaviour 20(1), 2128.

FAOSTAT. (2008). Production of pig meat ad chicken meat. Statistics 2007-2008, FAO. http://www.fao.org/economic/ess/ess-publications/ess-yearbook/faostatistical-yearbook-2007-2008/b-agricultural-production/.

Fernandez, X., Meunier-Salaün, M. C. and Mormede, P. (1994). Agonistic behavior, plasma stress hormones, and metabolites in response to dyadic encounters in domestic pigs: Interrelationships and effect of dominance status. Physiology and Behavior 56(5), 841-847.

Geers, R., Vranken, E., de Laet, B., Maes, F., Goedseels, V. and Berckmans, D. (1987). Lasting effects of housing conditions after weaning on feed efficiency and carcass grades of growing-finishing pigs. An analysis of field data. Livestock Production Science 16(2), 175-186.

Gentry, J. G., McGlone, J. J., Blanton, J. and Miller, M. F. (2002). Alternative housing systems for pigs: Influences on growth, composition, and pork quality. Journal of Animal Science 80(7), 1781-1790.

Gispert, M., Furnols, M., Gil, M., Velarde, A., Diestre, A., Carrión, D., Sosnicki, A. A. and Plastow, G. S. (2007). Relationships between carcass quality parameters and genetic types. Meat Science 77(3), 397-404.

Gnanaraj, P. T., Sivakumat, T., Arunachalan, S., Radhakrishnan, K. T. and Ramesh, V. (2002). Effect of excercise on carcass traits and blood of growing finishing pigs. Cheiron, 31, pp. 137-139. 
Gondret, F., Combes, S., Lefaucheur, L. and Lebret, B. (2005). Effects of exercise during growth and alternative rearing systems on muscle fibers and collagen properties. Reproduction Nutrition Development 45(1), 69-86.

Gonyou, H. W. (2001). The social behaviour of pigs. Edición: Keeling, L. J. y Gonyou, H. W. En: The Social Behaviour in Farm Animals. Pag. 147-176. Wallingford, Cabi Publishing.

Guy, J. H., Rowlinson, P., Chadwick, J. P. and Ellis, M. (2002). Behaviour of two genotypes of growing-finishing pig in three different housing systems. Applied Animal Behaviour Science 75(3), 193-206.

Hale, O. M., Newton, G. L. and Haydon, K. D. (1986). Effect of diet and exercise on performance, carcass traits and plasma components of growing-finishing barrows. Journal of Animal Science 62(3), 665-671.

Hansen, L. L., Claudi-Magnussen, C., Jensen, S. K. and Andersen, H. J. (2006). Effect of organic pig production systems on performance and meat quality. Meat Science 74(4), 605-615.

Hicks, T. A., McGlone, J. J., Whisnant, C. S., Kattesh, H. G. and Norman, R. L. (1998). Behavioral, Endocrine, Immune, and Performance Measures for Pigs Exposed to Acute Stress. Journal of Animal Science 76(2), 474-483.

Högberg, A., Pickova, J., Stern, S., Lundström, K. and Bylund, A. C. (2004). Fatty acid composition and tocopherol concentrations in muscle of entire male, castrated male and female pigs, reared in an indoor or outdoor housing system. Meat Science 68(4), 659-665. 
Hotzel, M. J., Machado, L. C. P., Wolf, F. M. and Dalla Costa, O. A. (2004). Behaviour of sows and piglets reared in intensive outdoor or indoor systems. Applied Animal Behaviour Science 86(1-2), 27-39.

Idexx. (2006). Chemistry Description and Guide. Vet Test Manual Operator, pp. $\mathrm{H} 1-\mathrm{H} 23$.

Isabel, B., Lopez-Bote, C. J., de la Hoz, L., Timón, M., García, C. and Ruiz, J. (2003). Effects of feeding elevated concentrations of monounsaturated fatty acids and vitamin E to swine on characteristics of dry cured hams. Meat Science 64(4), 475-482.

Jensen, K. H., Pedersen, L. J., Nielsen, E. K., Heller, K. E., Ladewig, J. and Jørgensen, E. (2004). Intermittent stress in pigs: Effects on behavior, pituitary -Adrenocortical axis, growth, and gastric ulceration. Physiology \& Behavior 59(4-5), 741-748.

Jensen, M. B. and Pedersen, L. J. (2010). Effects of feeding level and access to rooting material on behaviour of growing pigs in situations with reduced feeding space and delayed feeding. Applied Animal Behaviour Science 123(1-2), $1-6$.

Lawrence, A. B. and Terlouw, E. M. (1993). A review of behavioral factors involved in the development and continued performance of stereotypic behaviors in pigs. Journal of Animal Science 71(10), 2815-2825.

Lebret, B., Meunier-Salaün, M. C., Foury, A., Mormède, P., Dransfield, E. and Dourmad, J. Y. (2006). Influence of rearing conditions on performance, behavioral, and physiological responses of pigs to preslaughter handling, carcass traits, and meat quality. Journal of Animal Science 84(9), 2436-2447. 
Lebret, B. and Guillard, A. S. (2005). Outdoor rearing of cull sows: Effects on carcass, tissue composition and meat quality. Meat Science 70(2), 247-257.

López, J., Jesse, G. W., Becker, B. A. and Ellersieck, M. R. (1991). Effects of temperature on the performance of finishing swine: Il. Effects of a cold, diurnal temperature on average daily gain, feed intake, and feed efficiency. Journal of Animal Science 69(5), 1850-1855.

Macari, M., Zuim, S. M. F., Secato, E. R. and Guerreiro, J. (1986). Effects of ambient temperature and thyroid hormones on food intake by pigs. Physiology \& Behavior 36(6), 1035-1039.

Moinard, C., Mendl, M., Nicol, C. J. and Green, L. E. (2003). A case control study of on-farm risk factors for tail biting in pigs. Applied Animal Behaviour Science 81(4), 333-355.

Moisá, S., Basso, L., Bacci, R., Papotto, D., Alleva, G., Brunori, J. and Franco, R. (2007). Composición de la grasa intramuscular de carne porcina proveniente de diferentes sistemas de producción. Revista Argentina de Producción Animal 27(1), 347-395.

Moliterno, E. (1997). Método agronómico. Cangüé. no. 9: 32- 36. Cangüé 9, 32-36.

Morgan, C. A., Deans, L. A., Lawrence, A. B. and Nielsen, B. L. (1998). The effects of straw bedding on the feeding and social behaviour of growing pigs fed by means of single-space feeders. Applied Animal Behaviour Science 58(1-2), 2333.

Mormède, P., Andanson, S., Auperin, B., Beerda, B., Guqmenq, D., Malmkvist, J., Manteca, X., Manteuffel, G., Prunet, P., van Reenen, C. G., Richard, S. and 
Veissier, I. (2007). Exploration of the hypothalamic-pituitary-adrenal function as a tool to evaluate animal welfare. Physiology \& Behavior 92(3), 317-339.

Morrison, R. S., Johnston, L. J. and Hilbrands, A. M. (2007). The behaviour, welfare, growth performance and meat quality of pigs housed in a deep-litter, large group housing system compared to a conventional confinement system. Applied Animal Behaviour Science 103(1-2), 12-24.

Morrow-Tesch, J. L., McGlone, J. J. and Salakjohnson, J. L. (1994). Heat and Social Stress Effects on Pig Immune Measures. Journal of Animal Science 72(10), 2599-2609.

Nienaber, J. A., Hahna, G. L., Klemcke, H. G., Becker, B. A. and Blecha, F. (1989). Cyclic temperature effects on growing-finishing swine. Journal of Thermal Biology 14(4), 233-237.

Nilzén, V., Babol, J., Dutta, P. C., Lundeheim, N., Enfält, A. C. and Lundström, K. (2001). Free range rearing of pigs with access to pasture grazingá-- effect on fatty acid composition and lipid oxidation products. Meat Science 58(3), 267275.

O'Connell, N. E. and Beattie, V. E. (1999). Influence of environmental enrichment on aggressive behaviour and dominance relationships in growing pigs. Animal Welfare 8(3), 269-279.

Olsen, A. W., Dybkjaer, L. and Simonsen, H. B. (2001). Behaviour of growing pigs kept in pens with outdoor runs. II. Temperature regulatory behaviour, comfort behaviour and dunging preferences. Livestock Production Science 69(3), 265278. 
Orr, D. E. and Shen, V. (2006). World Pig Production, Opportunity or Threat? Midwest Swine Nutrition Conference, 3-8. Indiana, Indiana Farm Bureau.

Oyhantçabal, G. (2010). Evaluación de la sustentabilidad de la producción familiar de cerdos a campo: un estudio de seis casos en el Sur del Uruguay. Tesis de grado . Montevideo, Facultad de Agronomía UDELAR.

Prunier, A., Mounier, A. M. and Hay, M. (2005). Effects of castration, tooth resection, or tail docking on plasma metabolites and stress hormones in young pigs. Journal of Animal Science 83(1), 216-222.

Pugliese, C., Bozzi, R., Campodoni, G., Acciaioli, A., Franci, O. and Gandini, G. (2005). Performance of Cinta Senese pigs reared outdoors and indoors.: 1. Meat and subcutaneous fat characteristics. Meat Science 69(3), 459-464.

Puppe, B., Tuchscherer, M. and Tuchscherer, A. (1997).The effect of housing conditions and social environment immediately after weaning on the agonistic behaviour, neutrophil/lymphocyte ratio and plasma glucose level in pigs. Livestock Production Science 48(2), 157-164.

Raes, K., De Smet, S. and Demeyer, D. (2004). Effect of dietary fatty acids on incorporation of long chain polyunsaturated fatty acids and conjugated linoleic acid in lamb, beef and pork meat: a review. Animal Feed Science and Technology 113(1-4), 199-221.

Rodríguez-Estévez, V., García, A., Peña, F. and Gomez, A. G. (2009). Foraging of Iberian fattening pigs grazing natural pasture in the dehesa. Livestock Science 120(1-2), 135-143. 
Rudine, A. C., Sutherland, M. A., Hulbert, L., Morrow, J. L. and McGlone, J. J. (2007). Diverse production system and social status effects on pig immunity and behavior. Livestock Science 111(1-2), 86-95.

Ruis, M. A. W., te Brake, J. H. A., Engel, B., Ekkel, E. D., Buist, W. G., Blokhuis, H. J. and Koolhaas, J. M. (1997). The Circadian Rhythm of Salivary Cortisol in Growing Pigs: Effects of Age, Gender, and Stress. Physiology \& Behavior 62(3), 623-630.

Ruíz, J. y. López-Bote, C. (2005). Alimentación y calidad sensorial de cerdos destinados a la obtención de productos cárnicos de calidad diferenciada. IX Curso de Especialización FEDNA. Barcelona. 7-11-2005.

Rushen, J., Nay, T. S., Wright, L. R., Payne, D. C. and Foxcroft, G. R. (1995). Stress and nursing in the pig: Role of HPA axis and endogenous opioid peptides. Physiology \& Behavior 58(1), 43-48.

Sardi, L., Martelli, G., Lambertini, L., Parisini, P. and Mordenti, A. (2006). Effects of a dietary supplement of DHA-rich marine algae on Italian heavy pig production parameters. Livestock Science 103(1-2), 95-103.

SAS Institute Inc. (2008). SAS/STAT 9.2. User's Guide, SAS Institute Inc., Cary, NC (2008).

Schaefer, A. L., Salomons, M. O., Tong, A. K. W., Sather, A. P. and Lepage, P. (1990). The effect of environment enrichment on aggression in newly weaned pigs. Applied Animal Behaviour Science 27(1-2), 41-52.

Scott, K., Chennells, D. J., Campbell, F. M., Hunt, B., Armstrong, D., Taylor, L., Gill, B. P. and Edwards, S. A. (2006). The welfare of finishing pigs in two contrasting 
housing systems: Fully-slatted versus straw-bedded accommodation. Livestock Science 103(1-2), 104-115.

Smulders, D., Verbeke, G., MormFde, P. and Geers, R. (2006). Validation of a behavioral observation tool to assess pig welfare. Physiology \& Behavior 89(3), 438-447.

Stolba, A. and Wood-Gush, D. G. M. (1981). The assessment of behavioural needs of pigs under free-range and confined conditions. Applied Animal Ethology 7(4), 388-389.

Temple, D., Manteca, X., Velarde, A. and Dalmau, A. (2011). Assessment of animal welfare through behavioural parameters in lberian pigs in intensive and extensive conditions. Applied Animal Behaviour Science In Press, Corrected Proof.

Terlouw, C., Berne, A. and Astruc, T. (2009). Effect of rearing and slaughter conditions on behaviour, physiology and meat quality of Large White and Duroc-sired pigs. Livestock Science 122(2-3), 199-213.

Titto, E. A. L., Titto, C. G., Gatto, E. G., Noronha, C. M. S., Mourpo, G. B., Filho, J. C. M. N. and Pereira, A. M. F. (2010). Reactivity of Nellore steers in two feedlot housing systems and its relationship with plasmatic cortisol. Livestock Science 129(1-3), 146-150.

van de Weerd, H. A. and Day, J. E. L. (2009). A review of environmental enrichment for pigs housed in intensive housing systems. Applied Animal Behaviour Science 116(1), 1-20. 
Villagrá, A., Althaus, R.L., Lainez, M., Martinez, A.B. and Torres, A.G. (2007). Modelling of daily rhythms of behavioural patterns in growing pigs on two commercial farms. Biological Rhythm Research 38(5), 347-354.

Warnats, N., Van Oeckel, M. J. and Boucqué, C. V. (1998). Effect of dietary polyunsaturated fatty acids in pork bakfat on the quality of salami. Meat Science 66(1), 21-32.

Warriss, P. D. (1998). The welfare of slaughter pigs during transport. Animal Welfare 7(4), 365-381.

Weerd, H. A. V., Docking, C. M., Day, J. E. L., Breuer, K. and Edwards, S. A. (2006). Effects of species-relevant environmental enrichment on the behaviour and productivity of finishing pigs. Applied Animal Behaviour Science 99(3-4), 230247.

Weng, R. C., Edwards, S. A. and English, P. R. (1998). Behaviour, social interactions and lesion scores of group-housed sows in relation to floor space allowance. Applied Animal Behaviour Science 59(4), 307-316.

Woods, V. B. and Fearon, A. M. (2009). Dietary sources of unsaturated fatty acids for animals and their transfer into meat, milk and eggs: A review. Livestock Science 126(1-3), 1-20. 

Capítulo 6

Discusión general y conclusiones 



\section{Discusión general}

La intensificación es un proceso creciente en todo el mundo por razones económicas, pero también es creciente el interés social por el respeto del medio ambiente y el bienestar de los animales producidos en estos sistemas. En consecuencia, es necesario un enfoque integrador para dar respuestas a las necesidades emergentes de la ganadería actual teniendo en cuenta esas cuestiones.

En este contexto, el objetivo de la presente tesis es extractar elementos que permitan caracterizar aspectos productivos, de comportamiento y fisiológicos, que contribuyan a la valoración del bienestar en sistemas de producción de terneros y cerdos con diferentes grados de intensificación, y en el caso concreto de un sistema alternativo de producción de cerdos al aire libre, aspectos medioambientales.

En los capítulos 2 y 3 se constata que los diferentes sistemas de producción estudiados tienen influencia sobre el comportamiento de terneros Holstein en engorde, presentando distintos patrones generales y diarios de uso del tiempo. La intensificación tiene tres efectos fundamentales que afectan al comportamiento y bienestar de los animales: la disponibilidad de espacio (Petherick and Phillips, 2009), la alimentación y la riqueza del ambiente (Jensen and Pedersen, 2010).

Un hecho evidente en rumiantes es que el pastoreo es una conducta muy importante, como han puesto de manifiesto numerosos estudios (Chilibroste y col., 2007; Hejcmanová y col., 2009; Hessle, 2009; Huber y col., 2008). Pues bien, en este trabajo, cuando los animales tienen la posibilidad de pastorear, ello representa la actividad principal en cuanto a tiempo dedicado y en cambio, en aquellos que se encuentran en confinamiento y no tienen esa posibilidad, el 
tiempo total de ingesta de alimentos se reduce. La importancia del pastoreo para estos animales, queda de manifiesto al analizar el comportamiento del sistema que posee seis horas diarias de acceso a la pastura. Durante este período, los animales intensificaron el pastoreo en relación a aquellos con acceso permanente, llegando a tiempos acumulados de pastoreo muy parecidos. Esto ha sido observado anteriormente en vacas lecheras por Patterson y col. (1998) y Chilibroste y col. (2007), demostrando que los animales aprenden que el acceso a los pastos es limitado y por ello intensifican ese comportamiento en los períodos de acceso.

Como resultado de la mayor dedicación de tiempo al pastoreo, otros comportamientos disminuyen su frecuencia, como es el caso del descanso, que es uno de los comportamientos claramente relacionados con el bienestar de los animales (Faerevik y col., 2008). Aquí aparece entonces una de los posibles dilemas a la hora de utilizar el comportamiento como indicador de bienestar: los animales pastorean más si tienen la posibilidad de elegir pero restan tiempo a su descanso, al menos en las horas diurnas.

En otro enfoque del análisis, los sistemas están también modificando las respuestas comportamentales ante diferentes condiciones climáticas, como surge del análisis de correspondencias. En efecto, los terneros del sistema pastoril, realizan el pastoreo en situaciones de mayor confort (ausencia de frío y baja humedad), mientras que los de pastoreo por horas realizan ese comportamiento en forma más independiente de las condiciones del tiempo. Además, los animales confinados ven alterado su confort en condiciones climáticas adversas, lo que se refleja en una reducción del descanso en posición tumbada. Los patrones diarios de comportamiento también son afectados por los sistemas, en algunos casos por la probabilidad de aparición de un determinado comportamiento a una 
determinada hora, pero en otros incluso con tendencias opuestas a lo largo del día, como el consumo de heno y el pastoreo. Los animales en confinamiento, tienen el comportamiento opuesto al esperable en la ingestión de materia seca según el trabajo de Zobel y col. (2011), donde el consumo de materia seca se va reduciendo hacia la tarde. Sin embargo la tendencia concuerda con los resultados en el sistema con acceso a pastura durante seis horas, por lo que resulta claro que existe una modificación en los patrones diarios de consumo influenciada por una decisión de manejo. Esto puede resultar importante a la hora de determinar los horarios del acceso al pastoreo, procurando cambiar el comportamiento de consumo de los diferentes alimentos, para reducir las ineficiencias en la utilización del heno y la pastura que se dieron en este sistema.

Por otro lado, el comportamiento social es uno de los factores fundamentales a considerar en la evaluación del bienestar, en especial los comportamientos agonísticos. El incremento de este tipo de comportamiento ha sido establecido como una consecuencia de la reducción del espacio disponible en promedio para cada animal (Gygax y col., 2007; Napolitano y col., 2004) y la competencia por los recursos (Faerevik y col., 2007). En este sentido, nuestros resultados confirman esa tendencia, ya que los animales que permanecieron permanentemente en confinamiento, tuvieron una mayor cantidad de interacciones entre animales $y$ fundamentalmente un número mayor de interacciones negativas. Estas interacciones podrían haberse concentrado en las zonas de los comederos, lo que implicaría una competencia por los recursos. Esta mayor frecuencia de comportamiento agonístico podría estar evidenciando además problemas de bienestar. Desde el punto de vista práctico, surge de los propios resultados que la posibilidad de acceso al pastoreo en un período del día, podría reducir las interacciones negativas. 
En general se acepta que no se puede evaluar el bienestar de los animales con una simple medida, y por ello se deben utilizar una serie de indicadores que integran cuestiones de comportamiento, salud y fisiología (Broom, 2006). Por esta razón, en este trabajo se realizaron mediciones de indicadores fisiológicos en el suero sanguíneo para aportar más elementos al análisis. Sin embargo, estos indicadores no permitieron evidenciar problemas en la salud o niveles de estrés de los animales. No obstante, llaman la atención sobre algunos aspectos de manejo cotidiano que pueden afectar en general a animales de cualquier sistema, como puede ser, el traslado de grandes distancias con agrupamiento de animales. Este manejo podría estar sometiendo a los animales a condiciones de estrés físico, lo cual explicaría los altos valores de CK. Por otra parte, los niveles séricos de urea podrían estar demostrando un desequilibrio en el contenido de la dieta de los animales en el sistema pastoril, el cual podría ser corregido y hacer posible una mejora en la eficiencia de uso de los alimentos. El sistema de pastoreo durante seis horas tuvo un consumo muy alto de nitrógeno, aunque no se obtuvo una mayor ganancia de peso. Esto podría deberse a la combinación de dos factores: la sobrestimación del consumo de heno por efecto de las pérdidas por pisoteo y la existencia de "N bypass" que podría venir causado por la intensidad con la que se produce el pastoreo.

En lo que respecta a la producción de cerdos, el capítulo 5 se refiere a los aspectos productivos, de comportamiento y fisiológicos, de cerdos en engorde en dos sistemas de producción muy diferentes: uno convencional en confinamiento y otro al aire libre con acceso a pasturas, conocido localmente como sistema " $a$ campo". En este caso, el sistema confinado tradicional mostró un rendimiento productivo un poco superior al de los cerdos criados a campo. Sin embargo, deberían analizarse otros aspectos de la producción, más allá del crecimiento de 
los animales, ya que existen otros factores que afectan la ecuación de productividad y eficiencia. En este sentido se debería atender a los otros costes de producción como instalaciones y mano de obra, los cuales son muy diferentes en los sistemas estudiados, pero ello excede los objetivos de esta tesis.

También se han estudiado aspectos relaciones con la calidad de la carne y se han detectado diferencias en algunas características de la carne de los animales producidos en ambos sistemas. En este sentido, el sistema con acceso a pastura produce una mejora en el color de la carne por disminución de la percepción de palidez, lo que coincide con Echenique y col., (2009). Si bien existen componentes genéticos del color de la carne, en especial las carnes PSE, las cuales presentan características que son rechazadas por los consumidores (Bendall and Swatland, 1988), las diferencias genéticas no explicarían los cambios encontrados en éste trabajo. La variación de coloración de la carne es posiblemente debido a un efecto del mayor nivel de ejercicio físico, aunque no podría descartarse algún efecto de la pigmentación de la grasa intramuscular por el consumo de pastos (Galietta, 2005) cambio de color que también ha sido detectado en grasa subcutánea en cerdos de montanera (Carrapiso y García, 2005). En relación a la deposición de grasas y composición de ácidos grasos, las canales de los cerdos de campo son más magras, debido a las posibilidades de realizar ejercicio, lo que ha sido obtenido en otros trabajos (Basso y col., 2006; Gnanaraj y col., 2002). Asimismo, se constató una mayor concentración de ácidos grasos poli-insaturados en los animales provenientes del sistema a campo, lo cual responde al consumo de pastos (Hansen y col., 2006; Bee y col., 2004), a pesar de que esta fuente solo representó un porcentaje menor de la dieta. El aumento de los ácidos linolénico y linoleico, en especial algunos isómeros de este último, se destacan por su valor nutricional (Haro y col., 2006), esto podría agregarle interés a la carne producida 
en estos sistemas desde el punto de vista del consumidor. Sin embargo las altas concentraciones de ácidos grasos poli-insaturados, puede causar problemas tecnológicos a la industria en la elaboración de ciertos productos, debido a su susceptibilidad a la oxidación.

Al igual que en los bovinos, las características de los sistemas de producción modifican las frecuencias y pautas de comportamiento de los cerdos. En el sistema a campo los animales son más activos y dedican menos tiempo total al descanso, lo cual ya fue encontrado por varios autores (Terlouw y col., 2009; Hotzel y col., 2004). Además, la disponibilidad de espacio afecta a las pautas de comportamiento en cerdos en crecimiento (Villagrá y col., 2007), aunque ésta y la actividad general de los cerdos, no tienen una asociación lineal (Averós y col., 2010). Seguramente otras causas como el ambiente más rico en estímulos, contribuyan a esa mayor actividad detectada (Cagienard y col., 2005; Bolhuis y col., 2005). La hipótesis del efecto del ambiente enriquecido, se ve reforzada por el análisis de los comportamientos exploratorios, donde el pastoreo y la exploración, son los de mayor importancia en cuanto a proporción del tiempo, entre los comportamientos activos.

El comportamiento de descanso parece seguir una pauta más definida en los cerdos a campo, con una frecuencia casi absoluta en el mediodía cuando los animales se protegen del sol y de las altas temperaturas dentro de los refugios. En cambio, los animales confinados no parecen tener una preferencia dentro del período estudiado, descansando más tiempo en general y en cualquier momento del día. El interrogante que surge es si el incremento del descanso puede ser usado como indicador de bienestar o en realidad es una respuesta a un ambiente más pobre en estímulos. Tuyttens (2005) presenta múltiples evidencias de aumento de actividad causado por la motivación de enriquecimientos 
ambientales y a su vez la reducción del tiempo de descanso. En estas condiciones se considera que el bienestar de los animales mejora. Para interpretar la pauta de descanso desde el punto de vista del bienestar de los animales, son quizás más importantes otros atributos del mismo como la duración de los eventos de descanso, las colisiones entre animales durante el descanso y que éste se dé parcial o totalmente fuera del área destinada a ello, como fue demostrado para vacas lecheras por Plesch, y col. (2010). En este sentido, aunque el tiempo total de descanso fue inferior en los cerdos en extensivo, tenían tiempos definidos y largos que se daban mayoritariamente dentro del refugio, lo cual podría implicar un descanso "más efectivo" en términos de bienestar.

En este mismo sentido, la baja disponibilidad de espacio y recursos ambientales limitados, promueve las agresiones y el estrés social (Andersen y col., 2004). Los resultados obtenidos muestran que si bien el total de agresiones registradas no difirió entre sistemas, sí lo hicieron aquellas con respuesta o peleas, que en la escala utilizada pueden interpretarse como con mayor intensidad o grado de agresividad. Esto podría estar denotando problemas de bienestar en los animales confinados aunque no se llegue al punto de lesiones evidentes. También desde el punto de vista fisiológico los resultados evidencian un posible empobrecimiento del bienestar en los animales del sistema convencional, ya que fueron registrados mayores valores de cortisol que en los animales al aire libre. Esta diferencia se mantuvo en las muestras tomadas en matadero, lo cual implicaría que aunque podría haber un estrés causado por los sistemas, la respuesta aguda al manejo previo al sacrifico fue similar en ambos. Sin embargo, hay que tomar estos resultados con precaución porque concentraciones más altas de cortisol no siempre responden a situaciones de estrés, y otros factores, incluso la alimentación, podrían influir (Mormede y col., 2007). El resto de indicadores 
fisiológicos no permiten identificar problemas de salud atribuibles a los distintos sistemas.

En términos generales, considerando ambas especies, es posible visualizar que los sistemas al aire libre con acceso a pasturas, permiten a los animales, más allá de las diferencias biológicas, el desarrollo de comportamientos más acorde a lo que se puede considerar natural, incluso en estirpes con muchos años de selección en sistemas intensivos. Sin embargo, demostrar si ello realmente implica mejoras en el bienestar de los animales trasciende a los resultados obtenidos en la presente tesis y se requiere profundizar la investigación en varios aspectos.

En lo que se refiere a los efectos medioambientales de la producción de cerdos $a$ campo, se ha realizado una primera aproximación al conocimiento de la distribución y el ciclo de los nutrientes en el suelo y sus posibles pérdidas por lixiviado, escurrimiento superficial o volatilización. En este sistema de producción, es evidente que existen menos factores bajo control que en la producción en confinamiento, al menos en la etapa de granja. No obstante, los resultados obtenidos permiten inferir que con las cargas y manejo estudiados, en este sistema es posible mantener las concentraciones de nutrientes del sistemas en los niveles establecidos en el manual de evaluación de impacto ambiental de las actividades rurales (Stachetti y Moreira, 2007). Sin embargo, se debe ser cauto en menospreciar los posibles impactos ambientales, dada la importancia de los factores climáticos y edáficos en los flujos de nutriente dentro del sistema y sus pérdidas. Queda evidenciado que factores climáticos como la precipitación puede afectar fuertemente la dinámica de nutrientes en el sistema por su influencia en el crecimiento de las praderas y la actividad microbiana del suelo que da como resultado cambios en las tasas de degradación de la materia orgánica y los procesos de nitrificación y denitrificación (Frioni, 2006). La precipitación además 
produce pérdidas por escurrimiento superficial, que podrían ser puntualmente importantes si se producen eventos de lluvia intensa luego de una acumulación de nutrientes durante una sequía severa.

La tendencia de emisiones de amoníaco es decreciente con el transcurso de los días desde el cierre de las parcelas de pastoreo, confirmando lo observado en aplicaciones agrícolas de purín (Sommer y Hutchings, 2001; Misselbrook et al., 2004). No obstante, cabe destacar que los valores absolutos se encuentran muy por debajo de los reportados en éstos casos.

La comparación entre sistemas es importante para evaluar y mitigar los efectos ambientales, pero para ello se debe trascender a la fase de granja y considerar el tratamiento y la disposición final de los efluentes. En este sentido, existe una abundante información en la bibliografía internacional sobre la producción de efluentes y emisiones en sistemas confinados y el tratamiento posterior de los residuos, incluyendo su aplicación en suelos agrícolas (Burton y Turner, 2003). Sin embargo la información sobre esta materia en sistemas extensivos es muy reducida y parcial, por lo cual todo aporte de información científica puede resultar muy relevante. 


\section{Conclusiones}

De acuerdo a los resultados obtenidos en los capítulos precedentes se llega a las siguientes conclusiones generales:

1. Se detecta una mayor frecuencia de comportamientos sociales agonísticos en el sistema más intensivo de engorde de terneros, lo cual reflejaría un peor estado de bienestar de esos animales, aunque los indicadores fisiológicos no aportan evidencias al respecto.

2. Se han caracterizado dos diferentes sistemas de producción, concluyendo que los mismos afectan los patrones de comportamiento de los cerdos en engorde. En el sistema a campo los cerdos pueden desarrollar una gama más amplia de comportamientos, reducen el comportamiento agonístico y tienen menores concentraciones séricas de cortisol.

3. La ganancia de peso es superior en los cerdos engordados en confinamiento, lo cual puede deberse a una menor demanda energética por el menor nivel de actividad. Los cerdos criados en el sistema a campo muestran carnes menos pálidas, canales más magras y ácidos grasos más favorables desde el punto de vista nutricional.

4. Se ha descrito la evolución de la concentración de nutrientes en el suelo y componentes de la dinámica de su ciclo para las condiciones estudiadas. En estas condiciones se puede ver una importante permanencia de $\mathrm{N}$ y $\mathrm{P}$ en el suelo, con bajas pérdidas por volatilización y escurrimiento superficial. 


\section{Referencias}

Andersen, I. L., Nævdal, E., Bakken, M. y Boe, K. E. (2004). Aggression and group size in domesticated pigs, Sus scrofa: [']when the winner takes it all and the loser is standing small'. Animal Behaviour 68(4), 965-975.

Averós, X., Brossard, L., Dourmad, J. Y., de Greef, K. H., Edge, H. L., Edwards, S. A. Y Meunier-Salaün, M. C. (2010). A meta-analysis of the combined effect of housing and environmental enrichment characteristics on the behaviour and performance of pigs. Applied Animal Behaviour Science 127(3-4), 73-85.

Basso, L., Campagna, D., Brunori, J., Alleva, G., Silva, P., Franco, R. y Somenzini, D. (2006). Recría-terminación de cerdos al aire libre o en confinamiento: su influencia en los cortes comerciales de la res. Memorias VIII Congreso Nacional de Producción Porcina. Cordoba.

Bee, G., Guex, G. y Herzog, W. (2004). Free-range rearing of pigs during the winter: Adaptations in muscle fiber characteristics and effects on adipose tissue composition and meat quality traits. Journal of Animal Science 82(4), 12061218.

Bendall, J. R. y Swatland, H. J. (1988). A review of the relationships of $\mathrm{pH}$ with physical aspects of pork quality. Meat Science 24(2), 85-126.

Bolhuis, J. E., Schouten, W. G. P., Schrama, J. W. y Wiegant, V. M. (2005). Behavioural development of pigs with different coping characteristics in barren and substrate-enriched housing conditions. Applied Animal Behaviour Science 93(3-4), 213-228.

Broom, D. M. (2006). Behaviour and welfare in relation to pathology. Applied Animal Behaviour Science 97(1), 73-83. 
Cagienard, A., Regula, G. y Danuser, J. (2005). The impact of different housing systems on health and welfare of grower and finisher pigs in Switzerland. Preventive Veterinary Medicine 68(1), 49-61.

Carrapiso, A. I. y García, C. (2005). Instrumental colour of Iberian ham subcutaneous fat and lean (biceps femoris): Influence of crossbreeding and rearing system. Meat Science 71(2), 284-290.

Chilibroste, P., Soca, P., Mattiauda, D. A., Bentancur, O. y Robinson, P. H. (2007). Short term fasting as a tool to design effective grazing strategies for lactating dairy cattle: A review. Australian Journal of Experimental Agriculture 47(9), 1075-1084.

Echenique, A., Repiso, L., y Capra, G. (2009). Composición química y calidad sensorial de jamones curados provenientes de cerdos alimentados con una dieta rica en ácido oleico y pasturas. INNOTEC 4. Montevideo, LATU.

Faerevik, G., Andersen, I. L., Jensen, M. B. y Boe, K. E. (2007). Increased group size reduces conflicts and strengthens the preference for familiar group mates after regrouping of weaned dairy calves (Bos taurus). Applied Animal Behaviour Science 108(3-4), 215-228.

Faerevik, G., Tjentland, K., Lovik, S., Andersen, I. L. y Boe, K. E. (2008). Resting pattern and social behaviour of dairy calves housed in pens with different sized lying areas. Applied Animal Behaviour Science 114(1-2), 54-64.

Frioni, L. (2006). Microbiología: básica, ambiental y agrícola. Editorial: Facultad de Agronomía- UDELAR, Montevideo, pp. 1-464.

Galietta, G. (2005) Calidad de Carne, en: Utilización de pasturas en la alimentación de cerdos. Facultad de Agronomía- UDELAR, Montevideo. p 33-38 
Gnanaraj, P. T., Sivakumat, T., Arunachalan, S., Radhakrishnan, K. T. y Ramesh, V. (2002). Effect of excercise on carcass traits and blood of growing finishing pigs. Cheiron, 31, pp. 137-139.

Gygax, L., Siegwart, R. and Wechsler, B. (2007). Effects of space allowance on the behaviour and cleanliness of finishing bulls kept in pens with fully slatted rubber coated flooring. Applied Animal Behaviour Science 107(1-2), 1-12.

Hansen, L. L., Claudi-Magnussen, C., Jensen, S. K. y Andersen, H. J. (2006). Effect of organic pig production systems on performance and meat quality. Meat Science 74(4), 605-615.

Hejcmanová, P., Stejskalová, M., Pavlu, V. y Hejcman, M. (2009). Behavioural patterns of heifers under intensive and extensive continuous grazing on species-rich pasture in the Czech Republic. Applied Animal Behaviour Science 117(3-4), 137-143.

Hessle, A. K. (2009). Effects of social learning on foraging behaviour and live weight gain in first-season grazing calves. Applied Animal Behaviour Science 116(2-4), 150-155.

Hotzel, M. J., Machado, L. C. P., Wolf, F. M. y Dalla Costa, O. A. (2004). Behaviour of sows and piglets reared in intensive outdoor or indoor systems. Applied Animal Behaviour Science 86(1-2), 27-39.

Huber, R., Baumung, R., Wurzinger, M., Semambo, D., Mwai, O. y Winckler, C. (2008). Grazing, social and comfort behaviour of Ankole and crossbred (Ankoleálátholstein) heifers on pasture in south western Uganda. Applied Animal Behaviour Science 112(3-4), 223-234. 
Jensen, M. B. y Pedersen, L. J. (2010). Effects of feeding level and access to rooting material on behaviour of growing pigs in situations with reduced feeding space and delayed feeding. Applied Animal Behaviour Science 123(1-2), 1-6.

Misselbrook T.H., Smith KA, Jackson D.R. y Gilhespy S.L., 2004. Ammonia emissions from irrigation of dilute pig slurries. Biosystems Engineering 89(4), 473-484.

Mormede, P., Andanson, S., Auperin, B., Beerda, B., Guémené, D., Malmkvist, J., Manteca, X., Manteuffel, G., Prunet, P., van Reenen, C. G., Richard, S. y Veissier, I. (2007). Exploration of the hypothalamic-pituitary-adrenal function as a tool to evaluate animal welfare. Physiology and Behavior 92(3), 317-339.

Napolitano, F., De Rosa, G., Grasso, F., Pacelli, C. y Bordi, A. (2004). Influence of space allowance on the welfare of weaned buffalo (Bubalus bubalis) calves. Livestock Production Science 86(1-3), 117-124.

Patterson, D. M., McGilloway, D. A., Cushnahan, A., Mayne, C. S. y Laidlaw, A. S. (1998). Effect of duration of fasting period on short-term intake rates of lactating dairy cows. Animal Science 66(2), 299-305.

Petherick, J. C. y Phillips, C. J. C. (2009). Space allowances for confined livestock and their determination from allometric principles. Applied Animal Behaviour Science 117(1-2), 1-12.

Plesch, G., Broerkens, N., Laister, S., Winckler, C. y Knierim, U. (2010). Reliability and feasibility of selected measures concerning resting behaviour for the onfarm welfare assessment in dairy cows. Applied Animal Behaviour Science 126(1-2), 19-26. 
Sommer SG, Sogaard HT, Moller HB y Morsing S, 2001. Ammonia volatilization from sows on grassland. Atmospheric Environment 35, 2023-2032.

Stachetti, G. y Moreira, A. (2007). Manual de evaluación de impacto ambiental de actividades rurales.Editors: PPR-MGAP, PROCISUR IICA EMBRAPA. 1, IICA,. Montevideo, pp. 1-168.

Terlouw, C., Berne, A. y Astruc, T. (2009). Effect of rearing and slaughter conditions on behaviour, physiology and meat quality of Large White and Duroc-sired pigs. Livestock Science 122(2-3), 199-213.

Tuyttens, F. A. M. (2005). The importance of straw for pig and cattle welfare: $A$ review. Applied Animal Behaviour Science 92(3), 261-282.

Villagrá, A., Althaus, R. L., Lainez, M., Martinez, A. B. y Torres, A. G. (2007). Modelling of daily rhythms of behavioural patterns in growing pigs on two commercial farms. Biological Rhythm Research 38(5), 347-354. 



\section{Sumario}

En los últimos años han crecido a nivel internacional las exigencias en materia de las condiciones de producción de los productos derivados de la ganadería, con especial énfasis en los temas medioambientales y de bienestar animal. El trabajo realizado en la presente tesis pretende realizar aportes en la caracterización de diferentes sistemas de producción en estos aspectos. Para ello se realizaron trabajos en dos diferentes especies, bovinos y porcinos, y en diferentes sistemas de producción con grado variable de intensificación y uso de pasturas. Se han caracterizados los sistemas propuestos, encontrando que los sistemas evaluados no presentan características que puedan comprometer seriamente el bienestar de los animales. Sin embargo, se obtuvieron indicios de que los diferentes sistemas afectan el comportamiento de los animales y podrían provocar diferentes niveles de estrés. Por su parte, los sistemas con inclusión de pastoreo podrían tener una menor eficiencia biológica de utilización de los nutrientes por parte de los animales tanto en vacunos como en cerdos. Desde el punto de vista medioambiental, se han podido visualizar las pautas de distribución de nutrientes en el terreno, en el caso de cerdos al aire libre. 